In cooperation with the Montana Department of Environmental Quality

\title{
Water-Quality Characteristics of Montana Streams in a Statewide Monitoring Network, 1999-2003
}
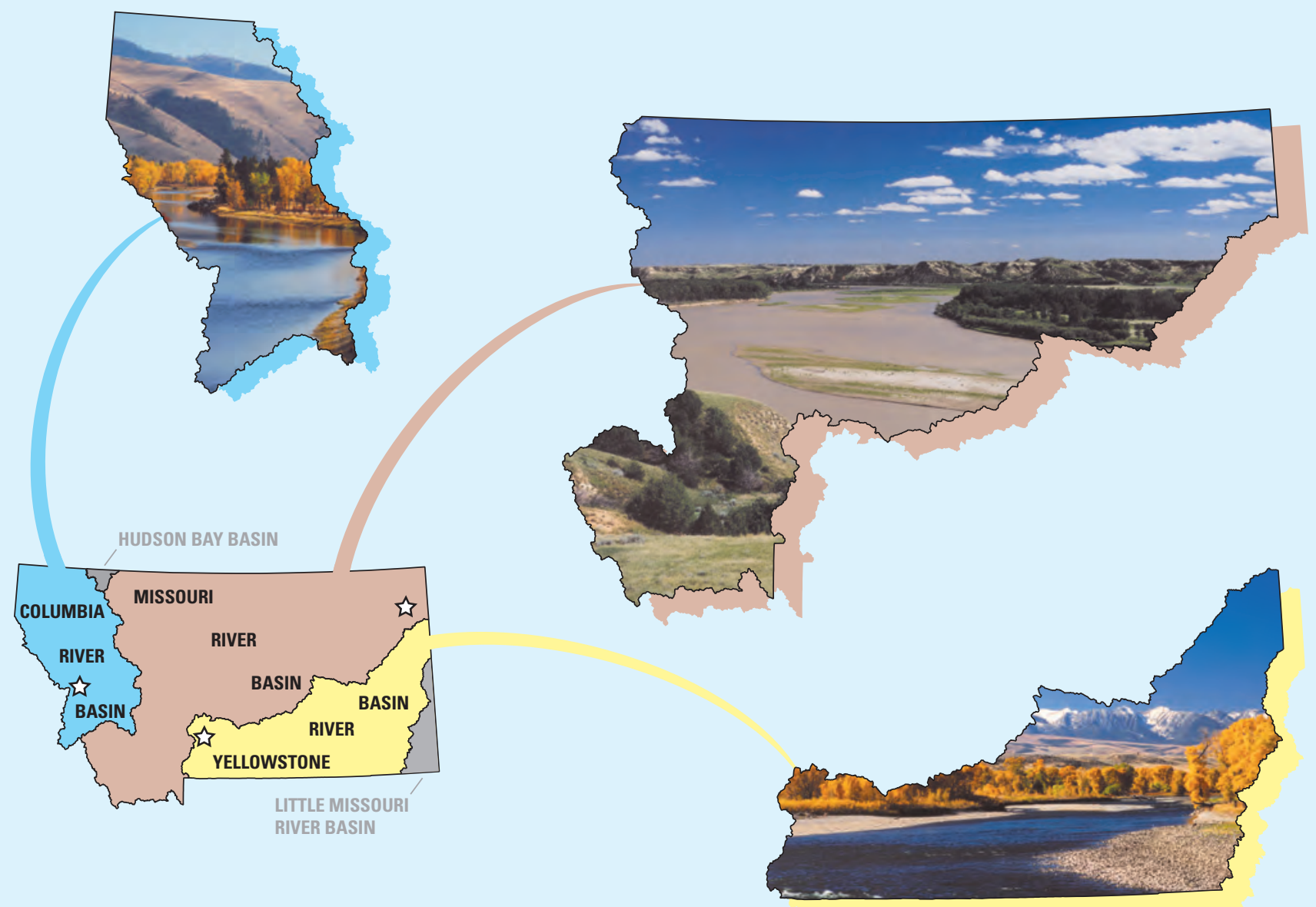

Scientific Investigations Report 2006-5046 
COVER PHOTOGRAPHS: View to the south showing the Bitterroot River near Missoula, Montana, taken in 2002 (upper left); view to the east showing the Missouri River near Culbertson, Montana, taken in 2001 (upper right); and view to the southwest showing the Yellowstone River near Livingston, Montana, taken in 2002 (lower right). Photographs by John Lambing, used by permission. indicates location of photograph site in basin. 


\section{Water-Quality Characteristics of Montana Streams in a Statewide Monitoring Network, 1999-2003}

By John H. Lambing and Thomas E. Cleasby

Prepared in cooperation with the Montana Department of Environmental Quality

Scientific Investigations Report 2006-5046 


\section{U.S. Department of the Interior \\ Dirk Kempthorne, Secretary \\ U.S. Geological Survey \\ P. Patrick Leahy, Acting Director}

\section{U.S. Geological Survey, Reston, Virginia: 2006}

For product and ordering information:

World Wide Web: http://www.usgs.gov/pubprod

Telephone: 1-888-ASK-USGS

For more information on the USGS--the Federal source for science about the Earth, its natural and living resources, natural hazards, and the environment:

World Wide Web: http://www.usgs.gov

Telephone: 1-888-ASK-USGS

Any use of trade, product, or firm names is for descriptive purposes only and does not imply endorsement by the U.S. Government.

Although this report is in the public domain, permission must be secured from the individual copyright owners to reproduce any copyrighted materials contained within this report.

Suggested citation:

Lambing, J.H., and Cleasby, T.E., 2006, Water-quality characteristics of Montana streams in a statewide monitoring network, 1999-2003: U.S. Geological Survey Scientific Investigations Report 2006-5046, 149 p. 


\section{Contents}

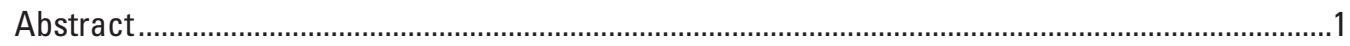

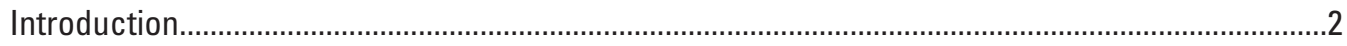

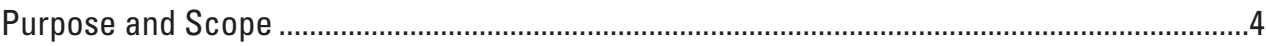

Description of Study Area .......................................................................................................4

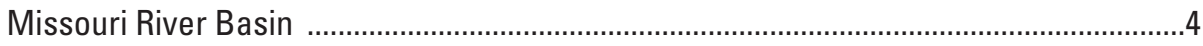

Yellowstone River Basin .............................................................................................

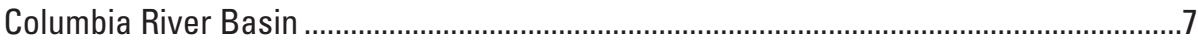

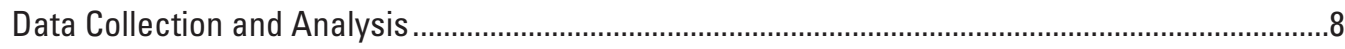

Design of Sampling Program ............................................................................................

Methods of Sample Collection, Processing, and Analysis ...........................................10

Quality Assurance................................................................................................................. 11

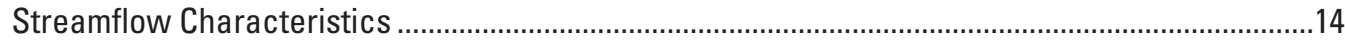

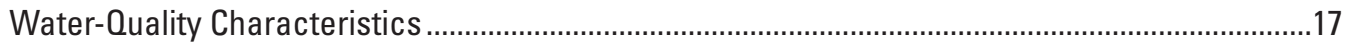

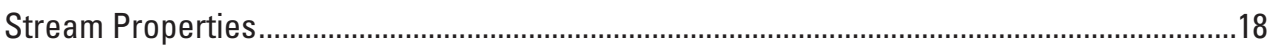

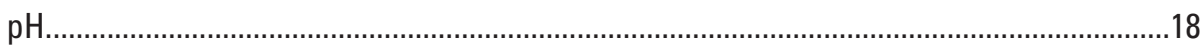

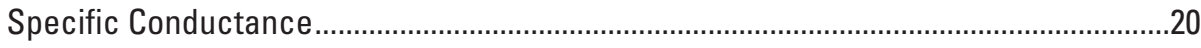

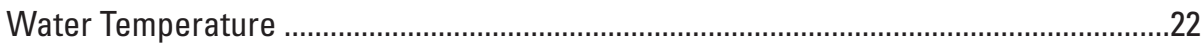

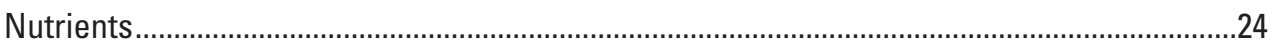

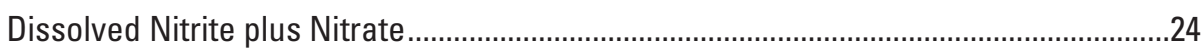

Total Ammonia Plus Organic Nitrogen .......................................................................26

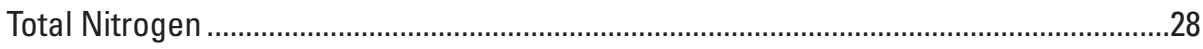

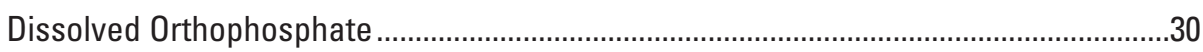

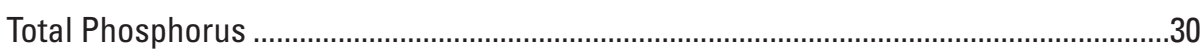

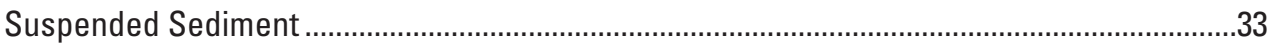

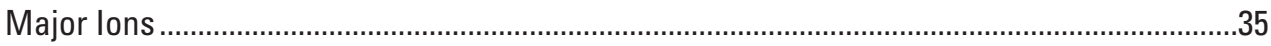

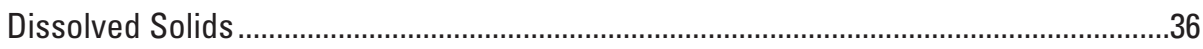

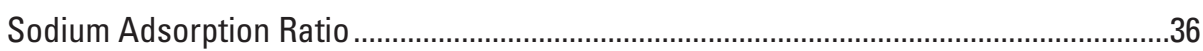

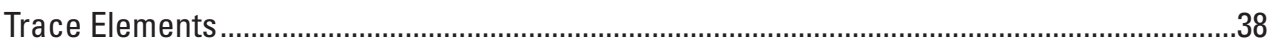

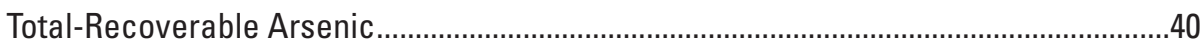

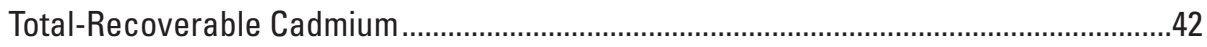

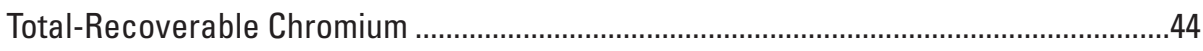

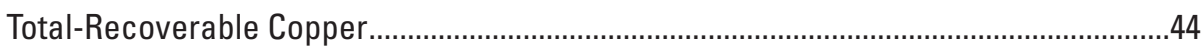

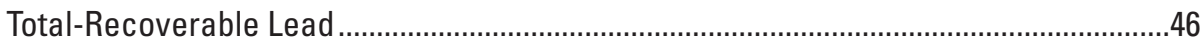

Total-Recoverable Nickel ........................................................................................... 48

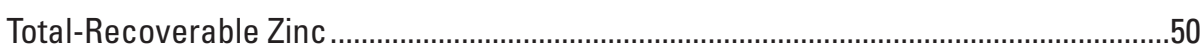

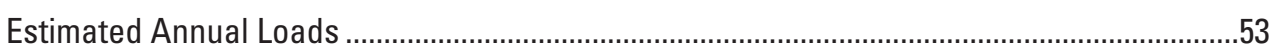

Computational Methods for Estimating Annual Loads ...................................................54

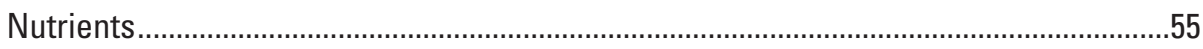

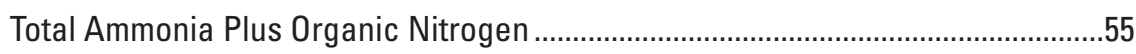

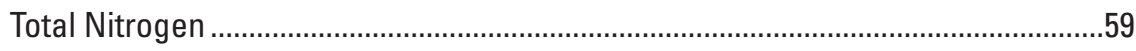

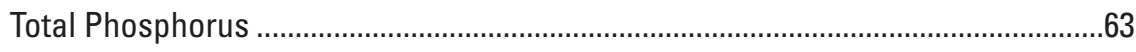

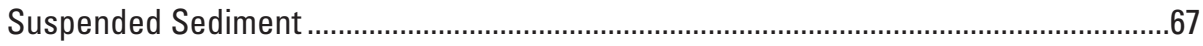




\section{Contents-Continued}

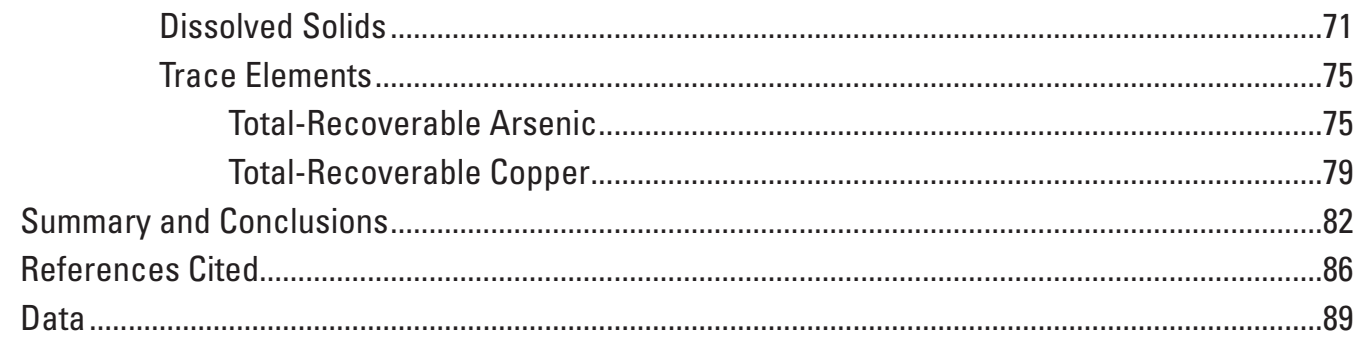

\section{Figures}

1. Map showing location of sampling sites in the statewide monitoring network, Montana, water years 1999-2003.

2. Annual hydrographs of mean daily streamflow during water years 1999-2003 and long-term mean daily streamflow for Missouri River at Toston,Yellowstone River near Sidney, and Clark Fork at St. Regis, Montana.

3-27. Graphs showing:

3. Statistical distribution of $\mathrm{pH}$ values at network sites in Montana, water years 1999-2003.

4. Statistical distribution of specific-conductance values at network sites in Montana, water years 1999-2003.

5. Statistical distribution of summer daily mean water temperatures at selected network sites with continuous temperature recorders in Montana, water years 1999-2003.

6. Statistical distribution of concentrations of dissolved nitrite plus nitrate at network sites in Montana, water years 1999-2003.

7. Statistical distribution of concentrations of total ammonia plus organic nitrogen at network sites in Montana, water years 1999-2003.

8. Statistical distribution of estimated concentrations of total nitrogen at network sites in Montana, water years 1999-2003.

9. Statistical distribution of concentrations of dissolved orthophosphate at network sites in Montana, water years 1999-2003.

10. Statistical distribution of concentrations of total phosphorus at network sites in Montana, water years 1999-2003..

11. Statistical distribution of concentrations of suspended sediment at network sites in Montana, water years 1999-2003.

12. Statistical distribution of concentrations of dissolved solids at network sites in Montana, water years 1999-2003.

13. Statistical distribution of sodium adsorption ratio (SAR) at network sites in Montana, water years 1999-2003.

14. Statistical distribution of concentrations of total-recoverable arsenic at network sites in Montana, water years 1999-2003.

15. Statistical distribution of concentrations of total-recoverable cadmium at network sites in Montana, water years 1999-2003. 


\section{Figures-Continued}

16. Statistical distribution of concentrations of total-recoverable chromium at network sites in Montana, water years 1999-2003.

17. Statistical distribution of concentrations of total-recoverable copper at network sites in Montana, water years 1999-2003.

18. Statistical distribution of concentrations of total-recoverable lead at network sites in Montana, water years 1999-2003.

19. Statistical distribution of concentrations of total-recoverable nickel at network sites in Montana, water years 1999-2003.

20. Statistical distribution of concentrations of total-recoverable zinc at network sites in Montana, water years 1999-2003.

21. Range and mean of estimated annual loads of total ammonia plus organic nitrogen at network sites in Montana, water years 1999-2003

22. Range and mean of estimated annual loads of total nitrogen at network sites in Montana, water years 1999-2003.

23. Range and mean of estimated annual loads of total phosphorus at network sites in Montana, water years 1999-2003.

24. Range and mean of estimated annual loads of suspended sediment at network sites in Montana, water years 1999-2003.

25. Range and mean of estimated annual loads of dissolved solids at network sites in Montana, water years 1999-2003.

26. Range and mean of estimated annual loads of total-recoverable arsenic at network sites in Montana, water years 1999-2003.

27. Range and mean of estimated annual loads of total-recoverable copper at network sites in Montana, water years 1999-2003.

\section{Tables}

1. Type and period of data collection at sampling sites in the statewide monitoring network, Montana.

2. Selected stream properties measured onsite and constituents analyzed in water samples.

3. Precision of analytical results for replicate samples, water years 1999-2003. .13

4. Streamflow characteristics for sites in the statewide monitoring network in Montana, water years 1999-2003 and long-term period of record.

5. General aquatic-life standards calculated from average hardness for groups of network sites with similar hardness, Montana.

6. Equations for estimating daily loads of total ammonia plus organic nitrogen and summaries of the range and mean of estimated annual loads at network sites in Montana, water years 1999-2003.

7. Equations for estimating daily loads of total nitrogen and summaries of the range and mean of estimated annual loads at network sites in Montana, water years 1999-2003.

8. Equations for estimating daily loads of total phosphorus and summaries of the range and mean of estimated annual loads at network sites in Montana, water years 1999-2003. 


\section{Tables-Continued}

9. Equations for estimating daily loads of suspended sediment and summaries of the range and mean of estimated annual loads at network sites in Montana, water years 1999-2003.

10. Equations for estimating daily loads of dissolved solids and summaries of the range and mean of estimated annual loads at network sites in Montana, water years 1999-2003.

11. Equations for estimating daily loads of total-recoverable arsenic and summaries of the range and mean of estimated annual loads at network sites in Montana, water years 1999-2003.

12. Equations for estimating daily loads of total-recoverable copper and summaries of the range and mean of estimated annual loads at network sites in Montana, water years 1999-2003.

13. Analytical results for replicate samples from sites in the statewide monitoring network in Montana, water years 1999-2003.

14. Analytical results for blank samples from sites in the statewide monitoring network in Montana, water years 1999-2003.

15. Statistical summary of water-quality data for periodically collected samples from sites in the statewide monitoring network in Montana, water years 1999-2003.

\section{Conversion Factors and Datums}

\begin{tabular}{|c|c|c|}
\hline Multiply & By & To obtain \\
\hline acre-foot (acre-ft) & 1,233 & cubic meter $\left(\mathrm{m}^{3}\right)$ \\
\hline cubic foot per second $\left(\mathrm{ft}^{\mathrm{t}} / \mathrm{s}\right)$ & 0.02832 & cubic meter per second $\left(\mathrm{m}^{3} / \mathrm{s}\right)$ \\
\hline foot $(\mathrm{ft})$ & 0.3048 & meter $(\mathrm{m})$ \\
\hline gallon (gal) & 3.785 & liter (L) \\
\hline gallon per minute (gal/min) & 0.06309 & liter per second $(\mathrm{L} / \mathrm{s})$ \\
\hline inch (in.) & 25.4 & millimeter $(\mathrm{mm})$ \\
\hline mile (mi) & 1.609 & kilometer (km) \\
\hline square mile $\left(\mathrm{mi}^{2}\right)$ & 2.590 & square kilometer $\left(\mathrm{km}^{2}\right)$ \\
\hline ton, short $(2,000$ pounds $)$ & 0.9072 & megagram $(\mathrm{Mg})$ \\
\hline ton per day (ton/d) & 0.9072 & megagram per day $(\mathrm{Mg} / \mathrm{d})$ \\
\hline ton per year (ton/yr) & 0.9072 & metric ton per year (ton/yr) \\
\hline
\end{tabular}

Temperature in degrees Celsius $\left({ }^{\circ} \mathrm{C}\right)$ may be converted to degrees Fahrenheit $\left({ }^{\circ} \mathrm{F}\right)$ as follows:

$$
{ }^{\circ} \mathrm{F}=\left(1.8 x^{\circ} \mathrm{C}\right)+32
$$

Vertical coordinate information is referenced to the National Geodetic Vertical Datum of 1929 (NGVD 29).

Horizontal coordinate information is referenced to the North American Datum of 1927 (NAD 27).

Altitude, as used in this report, refers to distance above the vertical datum (NGVD 29).

Water year is the 12-month period from October 1 through September 30 of the following calendar year. The water year is designated by the calendar year in which it ends. For example, water year 2005 is the period from October 1, 2004, through September 30, 2005. 


\title{
Abbreviated Units and Acronyms
}

\author{
Abbreviated units used in this report: \\ $\mu \mathrm{g} / \mathrm{L} \quad$ micrograms per liter \\ $\mu \mathrm{m} \quad$ micrometer \\ $\mu \mathrm{S} / \mathrm{cm} \quad$ microsiemens per centimeter at 25 degrees Celsius \\ $\mathrm{mg} / \mathrm{L} \quad$ milligrams per liter \\ $\mathrm{mm} \quad$ millimeter
}

Acronyms and definitions used in this report:

DI deionized water

LRL laboratory reporting level

LT-MDL long-term method detection limit

MDEO Montana Department of Environmental Quality

MRL minimum reporting level

$\mathrm{N} \quad$ nitrogen

NWIS National Water Information System

NWOL National Water Quality Laboratory

P phosphorus

$\mathrm{p} \quad$ significance level

$\mathrm{R}^{2} \quad$ coefficient of determination

RSD relative standard deviation

SAR sodium adsorption ratio

SE standard error

TDS total-dissolved solids

TKN total kjeldahl nitrogen

USDA U.S. Department of Agriculture

USEPA U.S. Environmental Protection Agency

USGS U.S. Geological Survey 



\title{
Water-Quality Characteristics of Montana Streams in a Statewide Monitoring Network, 1999-2003
}

\author{
By John H. Lambing and Thomas E. Cleasby
}

\section{Abstract}

A statewide monitoring network of 38 sites was operated during 1999-2003 in cooperation with the Montana Department of Environmental Quality to provide a broad geographic base of water-quality information on Montana streams. The purpose of this report is to summarize and describe the waterquality characteristics for those sites. Samples were collected at U.S. Geological Survey streamflow-gaging stations in the Missouri, Yellowstone, and Columbia River basins for stream properties, nutrients, suspended sediment, major ions, and selected trace elements. Mean annual streamflows were below normal during the period, which likely influenced water quality.

Continuous water-temperature monitors were operated at 26 sites. The median of daily mean water temperatures for the June-August summer period ranged from $12.5^{\circ} \mathrm{C}$ at Kootenai River below Libby Dam to $23.0^{\circ} \mathrm{C}$ at Poplar River near Poplar and Tongue River at Miles City. In general, sites in the Missouri River basin commonly had the highest water temperatures. Median daily mean summer water temperatures at four sites (Jefferson River near Three Forks, Missouri River at Toston, Judith River near Winifred, and Poplar River near Poplar) classified as supporting or marginally supporting cold-water biota exceeded the general guideline of $19.4{ }^{\circ} \mathrm{C}$ for cold-water biota. Median daily mean temperatures at sites in the network classified as supporting warm-water biota did not exceed the guideline of $26.7^{\circ} \mathrm{C}$ for warm-water biota, although several sites exceeded the warm-water guideline on several days during the summer.

Nutrient concentrations generally were lower in the Columbia River basin compared to the Missouri and Yellowstone River basins. Dissolved nitrite plus nitrate concentrations did not exceed the State of Montana human-health standard for drinking water of 10 milligrams per liter $(\mathrm{mg} / \mathrm{L})$ nitrate as nitrogen $(\mathrm{N})$ at any site in the network. Total nitrogen concentrations at network sites ranged from 0.043 to $31.6 \mathrm{mg} / \mathrm{L}$ as $\mathrm{N}$ and exceeded the ecoregion guideline of $1.50 \mathrm{mg} / \mathrm{L}$ for the prevention of eutrophication at several sites in the Missouri and Yellowstone River basins. In the Columbia River basin, concentrations of total nitrogen exceeded the State of Montana seasonal numeric standard of $0.300 \mathrm{mg} / \mathrm{L}$ in about 25 percent of the samples from two sites on the Clark Fork. Total phosphorus concentrations ranged from $<0.01$ to $15.4 \mathrm{mg} / \mathrm{L}$; concentrations at most sites in the Missouri and Yellowstone River basins occasionally to frequently exceeded both the general and ecoregion eutrophication guideline concentrations of 0.10 and $0.075 \mathrm{mg} / \mathrm{L}$, respectively. Total phosphorus concentrations at sites in the Columbia River basin only infrequently exceeded the general eutrophication guidelines. About 75 percent of the samples collected at Clark Fork at Turah Bridge and about 25 percent of the samples collected at Clark Fork at St. Regis exceeded the seasonal reach-specific numeric standards of $0.020 \mathrm{mg} / \mathrm{L}$ and $0.039 \mathrm{mg} / \mathrm{L}$, respectively, for total phosphorus.

Suspended-sediment concentrations varied widely at individual sites and among sites, ranging from 1 to 25,400 mg/L. Suspended-sediment concentrations commonly were lower in the Columbia River basin compared to the Missouri and Yellowstone River basins. Median suspended-sediment concentrations exceeded $100 \mathrm{mg} / \mathrm{L}$ at several sites in the Missouri and Yellowstone River basins; median concentrations in the Columbia River basin generally were less than $10 \mathrm{mg} / \mathrm{L}$. Overall, Powder River near Locate had the highest suspendedsediment concentrations in the network, with concentrations exceeding 2,000 mg/L in 25 percent of the samples.

Dissolved-solids concentrations ranged from 23 to 6,200 mg/L across the network. Samples from several sites in the Missouri and Yellowstone River basins had distinctly elevated concentrations relative to other sites and occasionally to frequently exceeded a general irrigation guideline of 1,000 mg/L. Three sites (Musselshell River at Mosby, Rosebud Creek near Rosebud, and Powder River near Locate) exceeded the guideline in more than 75 percent of the samples. Three other sites (Peoples Creek near Dodson, Milk River at Nashua, and Poplar River near Poplar) exceeded the guideline in 25 to 50 percent of the samples. No other sites exceeded the general irrigation guideline for dissolved solids. Sodium adsorption ratio (SAR) values ranged from $<0.1$ to 12 across the network and exceeded a general irrigation guideline of 7 at several sites in the Missouri and Yellowstone River basins. SAR values at Rosebud Creek near Rosebud commonly exceeded and Powder River near Locate occasionally exceeded the numeric standards of 4.5 and 7.5, respectively, established for SAR in those watersheds during the irrigation season. 
State of Montana human-health standards for drinking water for total-recoverable cadmium, chromium, and nickel were exceeded only infrequently by concentrations in samples from across the network; standards for copper and zinc were not exceeded. One or more sites in each of the three major river basins had sample concentrations that occasionally exceeded the human-health standard of 18 micrograms per liter $(\mu \mathrm{g} / \mathrm{L})$ for arsenic. The arsenic standard was exceeded in almost all samples from Missouri River at Toston and in about one-half of the samples from Yellowstone River near Livingston. Both sites receive geothermal waters enriched in arsenic from Yellowstone National Park. Concentrations of total-recoverable lead in one or more samples from each major river basin occasionally exceeded the human-health standard of $15 \mu \mathrm{g} / \mathrm{L}$ for lead; concentrations exceeded the standard in about 25 percent or more of the samples from Prickly Pear Creek near Clancy and Powder River near Locate.

Comparisons of trace-element concentrations to general aquatic-life standards (based on average hardness) indicate that chronic standards were exceeded infrequently at many of the network sites and acute standards were rarely exceeded. Aquatic-life standards for arsenic and chromium were not exceeded; chronic and acute standards for cadmium, nickel, and zinc were occasionally exceeded. In contrast, about onehalf of the sites in the network had one or more samples with concentrations that exceeded either chronic or acute aquaticlife standards for copper. Chronic and acute standards for copper were exceeded most commonly in samples from Clark Fork at Turah Bridge. About one-half of the sites had one or more samples with concentrations exceeding the chronic standard for lead; Prickly Pear Creek near Clancy exceeded the standard in about 50 percent of the samples.

General estimates of mean annual loads of selected constituents transported during 1999-2003 were used to assess relative contributions from upstream source areas compared to the load at the most downstream site on the mainstem. The largest mean annual loads of total ammonia plus organic nitrogen from upstream source areas in the Missouri, Yellowstone, and Columbia River basins, respectively, were transported past Missouri River at Toston (1,400 tons), Bighorn River near Bighorn (1,260 tons), and Clark Fork at St. Regis (1,290 tons). A similar pattern occurred for loads of total nitrogen. The largest mean annual loads of total phosphorus from upstream sources in each major river basin were transported past Missouri River at Toston (239 tons), Yellowstone River near Livingston (572 tons), and Clark Fork at St. Regis (183 tons). Suspended-sediment loads varied substantially among sites, with the largest mean annual loads from upstream sources in each major river basin transported past Milk River at Nashua (319,000 tons), Powder River near Locate (1,400,000 tons), and Clark Fork at St. Regis (146,000 tons). Dissolved-solids loads also varied widely among network sites, with the largest mean annual loads from upstream sources in each major river basin transported past Missouri River at Toston (682,000 tons), Bighorn River near Bighorn (1,410,000 tons), and Kootenai River below Libby Dam (1,230,000 tons).
Annual loads of trace elements were estimated for totalrecoverable arsenic and copper, except for sites where a large number of samples had concentrations less than the laboratory reporting level. The largest mean annual arsenic loads from upstream sources in the Missouri, Yellowstone, and Columbia River basins, respectively, were transported past Missouri River at Toston (109 tons), Yellowstone River near Livingston (62.1 tons), and Clark Fork at St. Regis (9.53 tons). The Missouri River at Toston had a notably larger arsenic load than any other network site, with more than 90 percent being contributed by the Madison River basin, which receives large volumes of arsenic-enriched geothermal waters from Yellowstone National Park. Similarly, a large arsenic load was estimated for Yellowstone River near Livingston, which also receives geothermal waters from the Park. The largest mean annual copper loads from upstream sources in each major river basin were transported past Missouri River at Toston (13.6 tons), Yellowstone River near Livingston (18.8 tons), and Flathead River at Perma (34.8 tons).

\section{Introduction}

Streams are vital to Montana's economic and social way of life. Demands on the water resources of Montana increase over time as the population grows and associated resource development expands. The increased use of land and water can affect both the quantity and quality of water, including the ability of water supplies to support beneficial uses such as drinking water, agriculture, aquatic life, and recreation. As water-quality issues arise, the State will need a comprehensive base of information from which to evaluate conditions and make resource-management decisions regarding use and protection of the water resources. Such information can allow for the development and implementation of effective management plans for maintaining long-term beneficial uses of Montana streams.

To address the need for a general characterization of water quality in Montana streams, a statewide monitoring network of 38 sites (fig. 1) was established in May 1999 by the U.S. Geological Survey (USGS), in cooperation with the Montana Department of Environmental Quality (MDEQ). The network represented the three major river basins in MontanaMissouri, Yellowstone, and Columbia — and included sites on mainstems and major tributaries. Water samples were collected periodically at these sites to document water-quality conditions, indicate seasonal and annual variations in water quality, identify exceedances of water-quality guidelines or standards, and establish a reference database for future assessments of long-term trends in water quality. The network was conceptually designed to be operated on a long-term and ongoing basis, pending availability of funding. However, because of funding limitations, data were collected only during water years 19992003 (October 1, 1998 through September 30, 2003). 


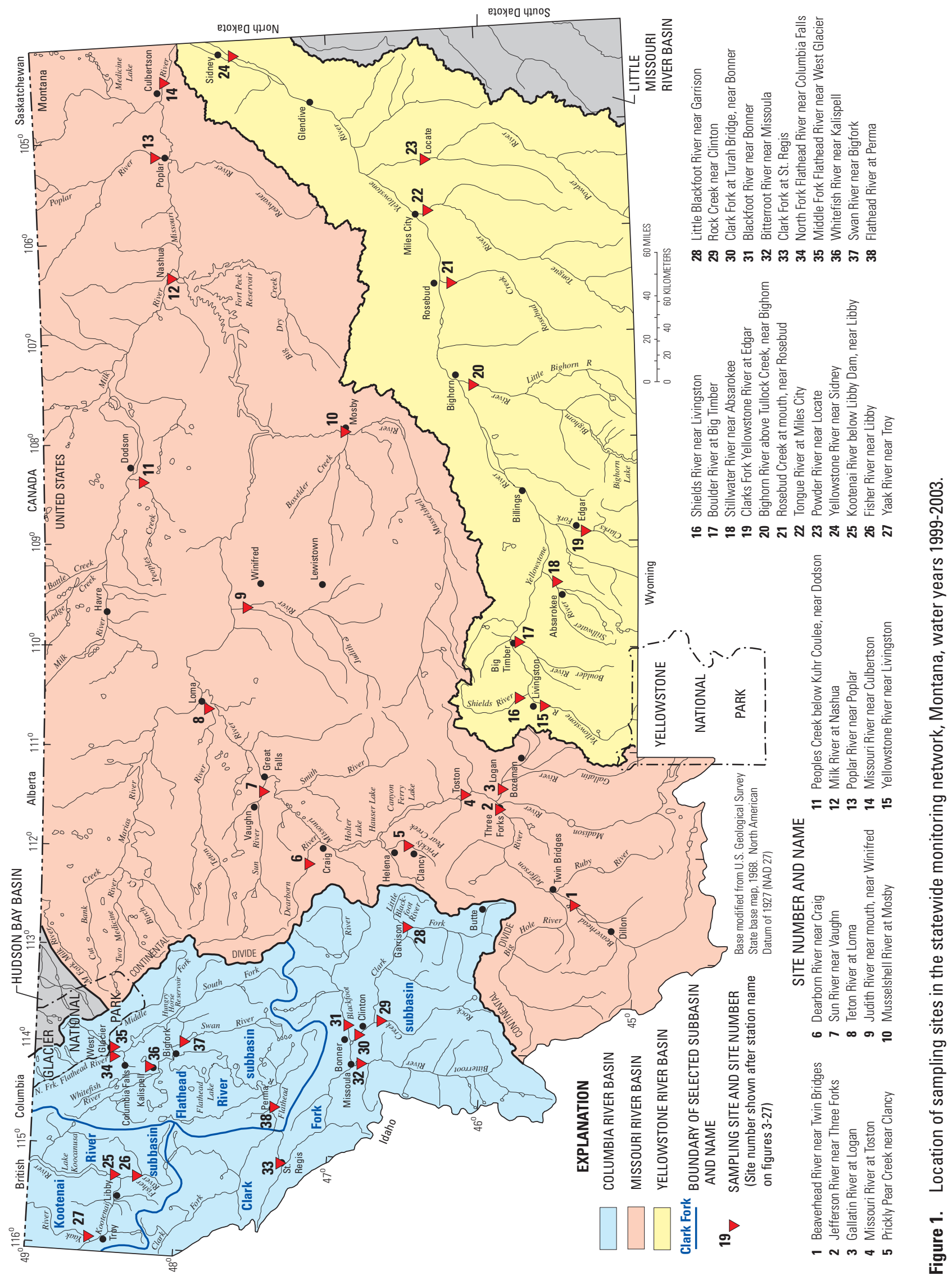


Water-Quality Characteristics of Montana Streams in a Statewide Monitoring Network, 1999-2003

\section{Purpose and Scope}

The purpose of this report is to summarize and describe water-quality characteristics for 38 Montana stream sites in the MDEQ statewide monitoring network (table 1) using data collected during water years 1999 through 2003. The water-quality data previously have been published in the USGS report series "Water Resources Data, Montana" (U.S. Geological Survey, issued annually). These data also are accessible on the USGS National Water Information System (NWIS) Web site for Montana (http://waterdata.usgs.gov/mt/nwis).

In this report, water-quality data on stream properties, nutrients, suspended sediment, major ions, and selected trace elements for the 5-year monitoring period are statistically summarized in both tabular and graphical form to describe general water-quality conditions and illustrate relative differences among sites. Quality-assurance data collected in conjunction with the water-quality samples are presented. Regression relations between instantaneous streamflow and constituent discharge at the times of periodic sampling visits also were examined to determine if statistically significant relations existed that could be used to estimate annual constituent loads. For those constituents having significant relations at all or most sites within a major river basin, annual loads were estimated to allow a relative comparison of constituent input from various source areas within the basin.

\section{Description of Study Area}

The sites in the statewide monitoring network were distributed within the Missouri, Yellowstone, and Columbia River basins in Montana (fig. 1). The presentation and discussion of data for each constituent are segregated by these major river basins. Water-use classifications and standards for selected properties and constituents have been designated for specific streams or stream reaches in Montana by the Montana Department of Environmental Quality (2002a,b). The classifications (table 1) indicate the beneficial uses to be supported by the condition of the water resource. The standards, both narrative and numeric, describe allowable limits required to maintain acceptable water quality. The following sections provide brief descriptions of each major river basin.

\section{Missouri River Basin}

The Missouri River mainstem begins at the confluence of three headwater streams - the Jefferson, Madison, and Gallatin Rivers. Draining approximately $91,560 \mathrm{mi}^{2}$ at the Missouri River near Culbertson (site 14, fig. 1), the Missouri River drains more than one-half of the land area in Montana and is Montana's largest river system (Moody and others, 1986).
From the Continental Divide in southwest Montana, the Missouri River and its headwater tributaries flow across more than 1,000 mi of Montana before leaving the State in the northeast corner where the river enters North Dakota. The river flows mostly in a northerly direction through mountain valleys to its confluence with the Marias River. Downstream from the Marias River, the Missouri River turns and flows generally eastward across a primarily prairie landscape to the North Dakota border. Water is impounded in four large reservoirs on the Missouri River mainstem-Canyon Ferry Lake, Hauser Lake, Holter Lake, and Fort Peck-plus several other reservoirs in tributary basins.

Two sites were sampled on the Missouri River mainstem-one in the upper basin (Missouri River at Toston, site 4), located downstream from the confluence of the three headwater streams; and one in the lower basin (Missouri River near Culbertson, site 14), located near the Montana-North Dakota border. Major tributaries to the Missouri River that were sampled include the Beaverhead River, Jefferson River, Gallatin River, Prickly Pear Creek, Dearborn River, Sun River, Teton River, Judith River, Musselshell River, Peoples Creek, Milk River, and Poplar River (fig. 1, table 1). For brevity, Peoples Creek below Kuhr Coulee, near Dodson will be referred to as Peoples Creek near Dodson in this report.

The climate in the Missouri River basin of Montana ranges from cold and wet in the mountainous areas to temperate and semiarid in the prairie areas. Mean annual precipitation ranges from $12 \mathrm{in.} \mathrm{in} \mathrm{much} \mathrm{of} \mathrm{the} \mathrm{prairie} \mathrm{areas} \mathrm{to} 100 \mathrm{in}$. in the northern mountains of the upper Marias River drainage near Glacier National Park (Moody and others, 1986). Altitude in the Missouri River basin in Montana ranges from about $1,860 \mathrm{ft}$ where the Missouri River exits Montana at the Montana-North Dakota border to about 11,300 ft in the mountains of southwestern Montana.

The 2000 population of the Missouri River basin in Montana was about 350,000 (Cannon and Johnson, 2004). Major land use in the drainage includes agricultural production, metals mining, logging, oil and gas production, and urbanization. Agriculture includes both farming and livestock production and occurs throughout most of the basin. Most of the mining occurs in the mountainous regions. Oil and gas is produced from subsurface reservoirs of fossil fuels, primarily in the north-central and northeastern part of the watershed.

The agricultural industry, which includes farming of irrigated cropland along alluvial valleys and benches, is the largest consumptive user of water in the Missouri River basin in Montana. In 2000, about 98 percent of the water withdrawals in the basin was for irrigation. Other consumptive water uses in the basin, in terms of percent of total withdrawal, include public-water supplies ( 1 percent) and livestock watering (0.5 percent) (Cannon and Johnson, 2004). 


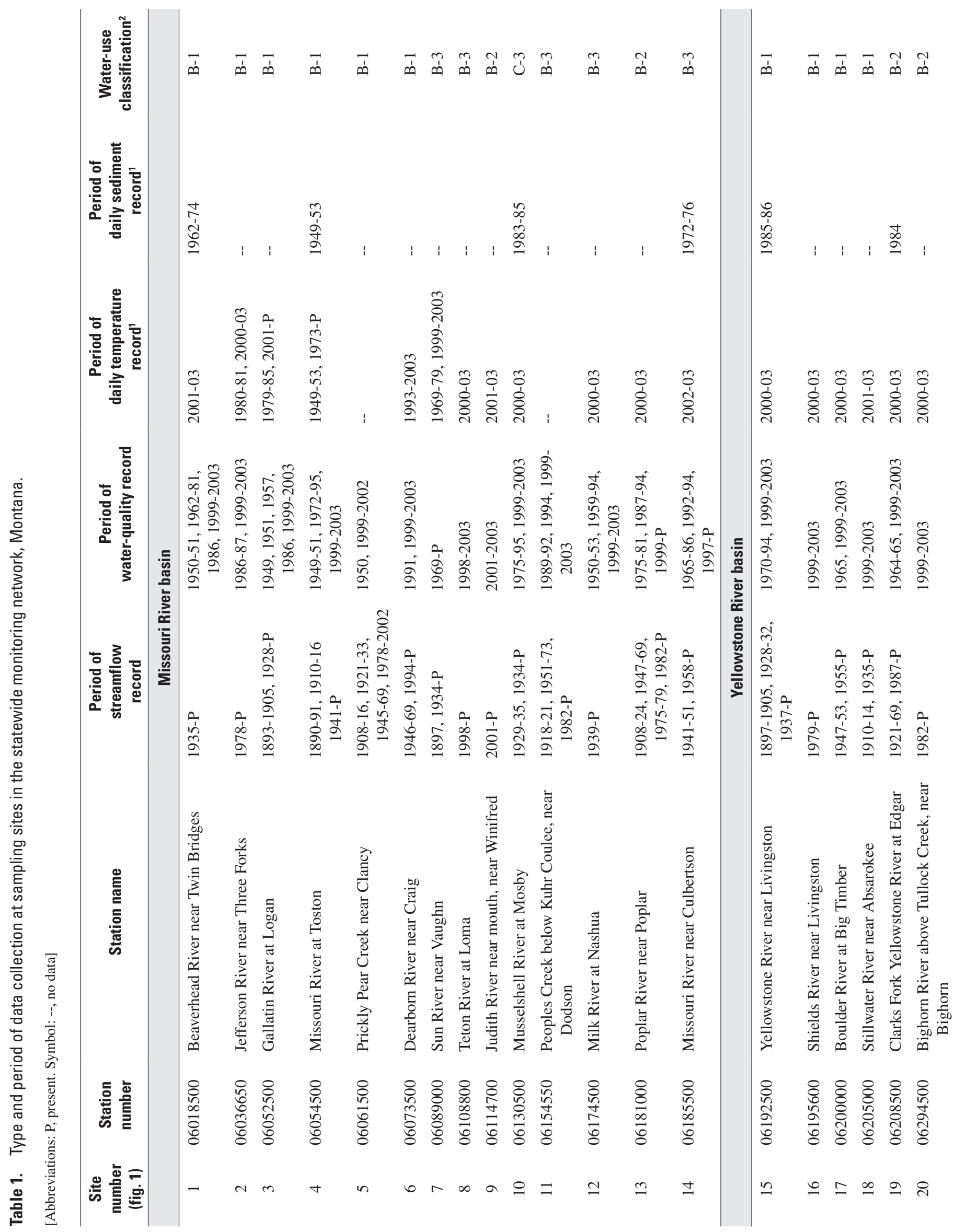




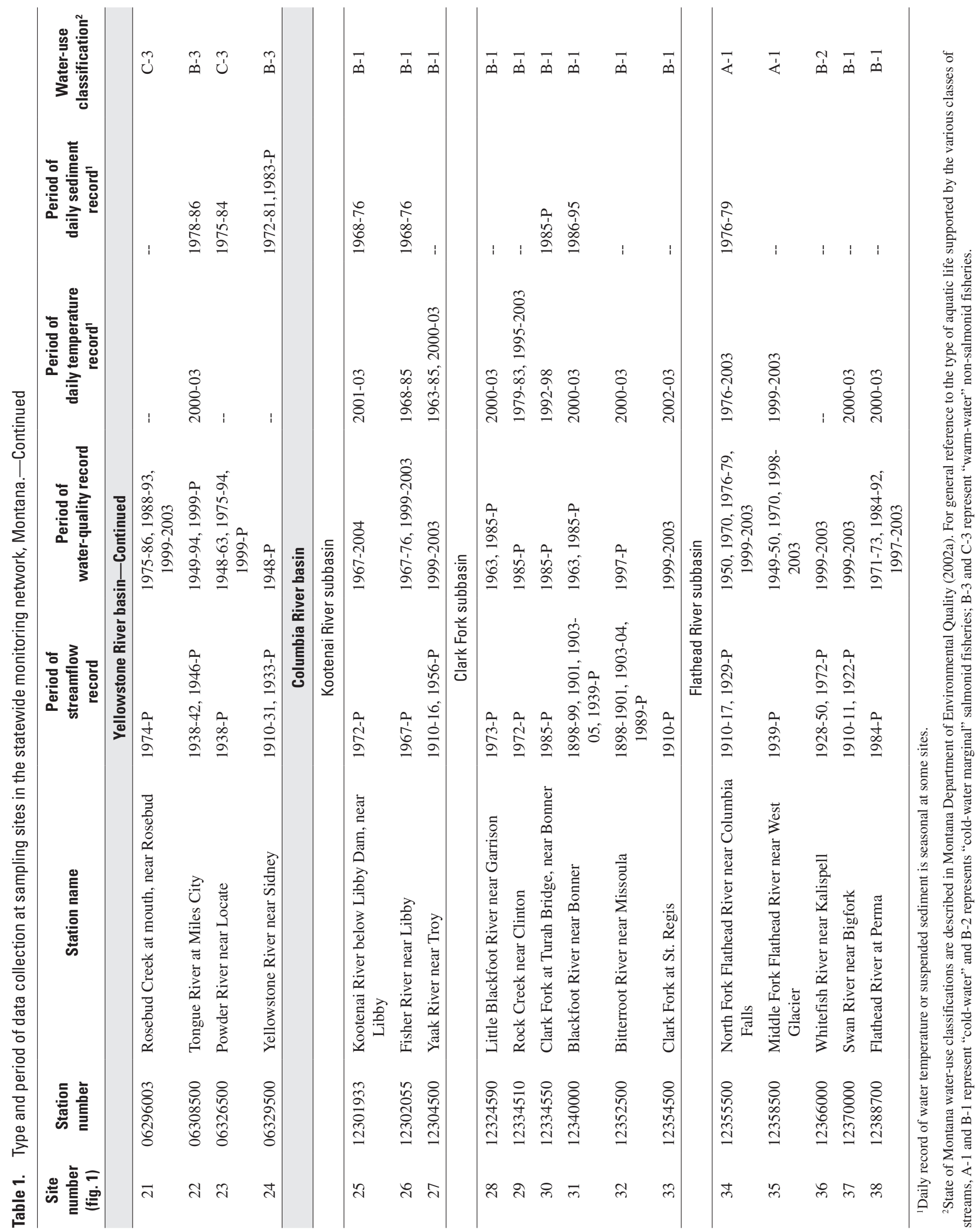




\section{Yellowstone River Basin}

The Yellowstone River originates in Wyoming and enters Montana near the northern boundary of Yellowstone National Park. The Yellowstone River drains an area of about 69,080 $\mathrm{mi}^{2}$ at the Yellowstone River near Sidney (site 24, fig. 1), with about one-half of the drainage area in Wyoming and about one-half in Montana. About 25 percent (about $36,000 \mathrm{mi}^{2}$ ) of Montana drains into the Yellowstone River basin. The Yellowstone River flows in a generally northeast direction across about $550 \mathrm{mi}$ of southern and eastern Montana. Most of the major tributaries flow into the Yellowstone River from the south, with their headwaters originating in Wyoming.

Two sites were sampled on the Yellowstone River mainstem-one in the upper basin (Yellowstone River near Livingston, site 15), located about $55 \mathrm{mi}$ downstream from Yellowstone National Park, and one in the lower basin (Yellowstone River near Sidney, site 24) near the Montana-North Dakota border. Major tributaries to the Yellowstone River that were sampled include the Shields River, Boulder River, Stillwater River, Clarks Fork Yellowstone River, Bighorn River, Rosebud Creek, Tongue River, and Powder River (fig. 1, table 1). For brevity, Bighorn River above Tullock Creek, near Bighorn will be referred to as Bighorn River near Bighorn in this report. The mainstem of the Yellowstone River is not impounded by large reservoirs; however, reservoirs regulate flow in the Bighorn and Tongue Rivers.

The climate in the Yellowstone River basin of Montana ranges from cold and moist in the mountainous areas to temperate and semiarid in the prairie areas. Mean annual precipitation ranges from less than 6 in. in the Clarks Fork Yellowstone River valley to more than $60 \mathrm{in}$. in the mountains near Yellowstone National Park (Moody and others, 1986). Altitude in the Montana portion of the Yellowstone River basin ranges from about 1,880 ft where the Yellowstone River exits Montana at the Montana-North Dakota border to almost 12,800 ft in the mountains of south-central Montana.

The 2000 population of the Montana portion of the Yellowstone River basin is about 228,000 (Cannon and Johnson, 2004). Major land use in the drainage includes agricultural production, coal and metals mining, electric-power generation, logging, oil and gas production, and urbanization. Montana's largest city, Billings, is located along the Yellowstone River. Agriculture includes both farming and livestock production. Active large-scale mines extract coal by surface-mining methods in the Tongue River basin. Most of the mining for metals occurs in the mountainous regions northeast of Yellowstone National Park. Oil and gas is produced from subsurface reservoirs primarily in the Powder and Bighorn River basins.

Irrigation was the largest consumptive water use in the Montana portion of the Yellowstone River basin in 2000, accounting for about 93 percent of water withdrawals. Other major water uses, in percent of total withdrawal, include electric power generation (4.5 percent), public-water supplies
(1.5 percent), and livestock watering ( 0.5 percent) (Cannon and Johnson, 2004).

\section{Columbia River Basin}

Three major subbasins of the Columbia River basinKootenai River, Clark Fork of the Columbia River (referred to as Clark Fork in this report), and Flathead River-were sampled in Montana west of the Continental Divide (fig. 1, table 1). The Kootenai River and Clark Fork do not converge within Montana, but both rivers exit Montana in the northwest corner of the State where they enter Idaho. The Flathead River is the largest tributary to the Clark Fork and enters the Clark Fork in the northwestern part of the State, about 85 miles upstream from the Montana-Idaho border.

The Kootenai River flows into Montana from British Columbia, Canada, in the northwest corner of the State at Lake Koocanusa. From Libby Dam, which forms Lake Koocanusa, the Kootenai River flows in a generally northwest direction for about $50 \mathrm{mi}$ before it enters Idaho. One mainstem site was sampled on the Kootenai River (Kootenai River below Libby Dam, near Libby, site 25); for brevity, this site will be referred to as Kootenai River below Libby Dam in this report. Major tributaries of the Kootenai River that were sampled include Fisher Creek and the Yaak River. The Kootenai River in Montana drains only about 3 percent (about 4,000 $\mathrm{mi}^{2}$ ) of Montana's land area; most of its drainage basin is in Canada. The Kootenai River has the second largest mean annual streamflow in the State (Moody and others, 1986).

The Clark Fork mainstem originates at the confluence of Silver Bow and Warm Springs Creeks in west-central Montana. From the Continental Divide near Butte, the headwater tributaries and the Clark Fork mainstem flow in a generally northwest direction across about $340 \mathrm{mi}$ of western Montana before flowing into Idaho in the northwest corner of the State. Two sites were sampled on the Clark Fork mainstem-one in the upper basin (Clark Fork at Turah Bridge, near Bonner, site 30) and one in the lower basin (Clark Fork at St. Regis, site 33). For brevity, the upper-basin site will be referred to as Clark Fork at Turah Bridge in this report. Major tributaries of the Clark Fork that were sampled include the Little Blackfoot

River, Rock Creek, Blackfoot River, Bitterroot River, and Flathead River. The Clark Fork near the Idaho border (including the Flathead River basin) drains approximately $22,000 \mathrm{mi}^{2}$, or about 15 percent of the State's land area. Although the Clark Fork basin is smaller than the Missouri or Yellowstone River basins, the mean annual streamflow of the Clark Fork is the largest in Montana (Moody and others, 1986).

The Flathead River is a tributary of the Clark Fork; however, it enters the Clark Fork downstream from the most downstream mainstem site (Clark Fork at St. Regis, site 33). Thus, inflow from the Flathead River to the Clark Fork mainstem does not affect the water quality or loads measured at Clark Fork at St. Regis. The Flathead River and its headwater tributaries flow across about $220 \mathrm{mi}$ of northwestern Montana, which includes about $30 \mathrm{mi}$ of Flathead Lake. The 
Flathead River drains about $8,800 \mathrm{mi}^{2}$, or about 6 percent of Montana. The North, South, and Middle Forks Flathead River converge upstream from Flathead Lake near Kalispell. These forks originate in the mountains along the Continental Divide of northern Montana and Canada. Downstream from Flathead Lake, the Flathead River flows in a generally southwest direction and enters the Clark Fork near Perma. The Flathead River at Perma (site 38, fig. 1) near the mouth of the Flathead River was sampled. Major tributaries to the Flathead River that were sampled include the North Fork Flathead River, Middle Fork Flathead River, Whitefish River, and Swan River. Two large impoundments in the Flathead River basin, Flathead Lake and Hungry Horse Reservoir, have a combined storage capacity of over 5,000,000 acre-ft (Cannon and Johnson, 2004). A large natural lake (Swan Lake) is located in the lower part of the Swan River basin immediately upstream from Swan River near Bigfork (site 37).

The climate on the west side of the State is generally more temperate and wetter than on the east side, although some intermontane valleys are semiarid. Mean annual precipitation ranges from $12 \mathrm{in}$. in the valley near the confluence of the Flathead River and Clark Fork to over 100 in. in the northern mountains (Moody and others, 1986). Altitude in the Montana portion of the Columbia River basin ranges from about 1,820 ft where the Kootenai River exits Montana at the Montana-Idaho border (the lowest point in the State) to about $10,600 \mathrm{ft}$ at the Continental Divide in southwestern Montana.

The 2000 population in the Columbia River basin of Montana was about 320,000 (Cannon and Johnson, 2004). Major land uses in the basin include metals mining, logging, agricultural production, and urbanization. In recent years, large population increases have occurred in the valleys of the Bitterroot and Flathead Rivers, resulting in rapid urban development. Historically, extensive metal mining has occurred in the upper Clark Fork basin, and smaller-scale mining continues in some areas throughout the Columbia River basin. Logging operations and associated timber processing industries are common in the northwest corner of the State where forest lands are extensive. Agriculture, including irrigated crop and hay production, occurs along most of the major river valleys.

Major consumptive water uses in the Montana portion of the Columbia River basin in 2000, in percent of total withdrawals, were irrigation (91 percent), public-water supplies (4 percent), industrial (4 percent), and livestock watering (0.3 percent) (Cannon and Johnson, 2004).

\section{Data Collection and Analysis}

\section{Design of Sampling Program}

The statewide monitoring network (table 1) was designed to provide a systematic measure of water quality that would allow for general characterization of 1999-2003 conditions across the State, as well as provide a reference to assess changes over time. To maximize the use of the water-quality data, as well as to improve logistical and cost efficiency, sites were located at active USGS streamflow-gaging stations. The availability of quantitative streamflow information enhances the ability to understand how water quality varies in response to changing flow conditions. Sites were preferentially selected where current or former USGS water-quality programs existed to obtain information that could be compared to historical data, supplement other sampling efforts to enhance characterization of conditions, and lessen funding requirements for the statewide monitoring program.

Sites in the statewide monitoring network (fig. 1) primarily were located on large streams, either on the mainstems of the major rivers or on their major tributaries. Tributary sites commonly were located near the mouth in order to characterize the cumulative quality of water draining from the entire watershed. One of the 38 network sites (Judith River near mouth, near Winifred, site 9) was added in May 2001, two years after the start of the monitoring program; therefore, this site has less sample data and streamflow record than the other network sites. Stillwater River near Absarokee had only seasonal record for daily streamflow during the first year of network operation. During the last year of network operation, daily streamflow data collection was discontinued for Prickly Pear Creek near Clancy.

The description of water quality for a large number of major tributaries allows for comparison of conditions among subbasins within the major river basins to assess the relative differences in quality, potential degree of impairment, and influence on water quality in the mainstem. Where an upperbasin and lower-basin mainstem site were available, water quality can be compared between the two sites to evaluate the physical and chemical changes resulting from the collective contributions of tributary inflows, geologic influences, and land-use activities. Such relative comparisons can help to identify priority areas that might need more intensive monitoring to characterize conditions or resource-management plans to address potential risks to beneficial water uses.

Samples were collected at a frequency of four times per year for field measurements of selected stream properties and laboratory analysis of nutrients and suspended sediment (table 2) to provide broad coverage of hydrologic and seasonal conditions. Samples also were analyzed for major ions and selected trace elements at a frequency of two times per year near the times of annual maximum and minimum flows to span the range of concentrations that might be expected. 
Table 2. Selected stream properties measured onsite and constituents analyzed in water samples.

[Abbreviations: $\mathrm{CaCO}_{3}$, calcium carbonate; ${ }^{\circ} \mathrm{C}$, degrees Celsius; $\mathrm{ft}^{3} / \mathrm{s}$, cubic feet per second; LRL, laboratory reporting level; $\mathrm{mg} / \mathrm{L}$, milligrams per liter; mm, millimeter; MRL, minimum reporting level; N, nitrogen; P, phosphorus; SAR, sodium adsorption ratio; ton/d, tons per day; $\mu \mathrm{g} / \mathrm{L}$, micrograms per liter; $\mu \mathrm{S} / \mathrm{cm}$, microsiemens per centimeter at $\left.25^{\circ} \mathrm{C}\right]$

\begin{tabular}{|c|c|c|c|}
\hline \multicolumn{2}{|c|}{ Onsite measurement } & \multicolumn{2}{|l|}{ Laboratory analysis ${ }^{1}$} \\
\hline Stream property & MRL & Constituent & $\mathbf{L R L}^{2}$ \\
\hline streamflow & $0.01 \mathrm{ft}^{3} / \mathrm{s}$ & Major ions: & \\
\hline $\mathrm{pH}$ & .1 units & hardness, dissolved & $1 \mathrm{mg} / \mathrm{L}$ \\
\hline specific conductance & $1 \mu \mathrm{S} / \mathrm{cm}$ & calcium, dissolved & $.012-.02 \mathrm{mg} / \mathrm{L}$ \\
\hline \multirow[t]{28}{*}{ water temperature } & $.5{ }^{\circ} \mathrm{C}$ & magnesium, dissolved & $.004-.014 \mathrm{mg} / \mathrm{L}$ \\
\hline & & potassium, dissolved & $.16 \mathrm{mg} / \mathrm{L}$ \\
\hline & & sodium adsorption ratio (SAR) & $0.1-1$ \\
\hline & & sodium, dissolved & $.06-.1 \mathrm{mg} / \mathrm{L}$ \\
\hline & & alkalinity, dissolved as $\mathrm{CaCO}_{3}$ & $1-2 \mathrm{mg} / \mathrm{L}$ \\
\hline & & chloride, dissolved & $.08-.33 \mathrm{mg} / \mathrm{L}$ \\
\hline & & fluoride, dissolved & $.1-.17 \mathrm{mg} / \mathrm{L}$ \\
\hline & & silica, dissolved & $.02-.16 \mathrm{mg} / \mathrm{L}$ \\
\hline & & sulfate, dissolved & $.1-.31 \mathrm{mg} / \mathrm{L}$ \\
\hline & & sum of constituents (dissolved solids) & $1 \mathrm{mg} / \mathrm{L}$ \\
\hline & & Nutrients: & \\
\hline & & ammonia plus organic nitrogen, total as $\mathrm{N}$ & $.08-.1 \mathrm{mg} / \mathrm{L}$ \\
\hline & & nitrite, dissolved as $\mathrm{N}$ & $0.001-.01 \mathrm{mg} / \mathrm{L}$ \\
\hline & & nitrite plus nitrate, dissolved as $\mathrm{N}$ & $.005-.05 \mathrm{mg} / \mathrm{L}$ \\
\hline & & orthophosphate, dissolved as $\mathrm{P}$ & $.001-.007 \mathrm{mg} / \mathrm{L}$ \\
\hline & & phosphorus, total as $\mathrm{P}$ & $.004-.06 \mathrm{mg} / \mathrm{L}$ \\
\hline & & Trace elements: & \\
\hline & & arsenic, total recoverable & $1-4 \mu \mathrm{g} / \mathrm{L}$ \\
\hline & & cadmium, total recoverable & $.04-1 \mu \mathrm{g} / \mathrm{L}$ \\
\hline & & chromium, total recoverable & $.6-1 \mu \mathrm{g} / \mathrm{L}$ \\
\hline & & copper, total recoverable & $.6-20 \mu \mathrm{g} / \mathrm{L}$ \\
\hline & & lead, total recoverable & $.06-3 \mu \mathrm{g} / \mathrm{L}$ \\
\hline & & nickel, total recoverable & $.16-2 \mu \mathrm{g} / \mathrm{L}$ \\
\hline & & zinc, total recoverable & $1-40 \mu \mathrm{g} / \mathrm{L}$ \\
\hline & & Suspended sediment: & \\
\hline & & concentration & $1 \mathrm{mg} / \mathrm{L}$ \\
\hline & & percent finer than $0.062 \mathrm{~mm}$ & 1 percent \\
\hline & & suspended-sediment discharge & .01 ton $/ \mathrm{d}$ \\
\hline
\end{tabular}

${ }^{1}$ Laboratory analysis of chemical constituents done by U.S. Geological Survey National Water Quality Laboratory in Denver, Colo. Laboratory analysis of suspended sediment done by U.S. Geological Survey sediment laboratory in Helena, Mont.

${ }^{2}$ Laboratory reporting levels varied for selected constituents during monitoring period. 

ing:

The four samples per year typically were collected dur-

1. Late winter or early spring to describe conditions during ice breakup or low-elevation snowmelt runoff (rising limb of annual hydrograph);

2. Late spring or early summer to describe conditions during increased runoff from rainfall and high-elevation snowmelt (peak flow of annual hydrograph);

3. Midsummer to describe the period of medium-flow conditions and warm-weather increases in stream biological productivity (falling limb of annual hydrograph); and

4. Late summer or fall to describe base-flow conditions predominated largely by ground-water inflow (minimum flow of annual hydrograph).

Sites where other USGS sampling programs were already in operation either satisfied the sampling requirements of the statewide monitoring program, required extra laboratory analyses to match the constituents for the statewide program, or supplemented the program with additional data. At several sites, other USGS programs were either discontinued or reduced in scale during the monitoring period, which resulted in some data not being collected. In addition, extended periods of no flow prevented collection of scheduled samples at some sites. All available USGS data for sites in the monitoring network during water years 1999-2003 were used to characterize water-quality conditions.

An attempt was made to balance the need to obtain data at many sites over a broad geographic area while maintaining a sampling intensity that was generally adequate to describe seasonal and hydrologic variability of water quality. A sampling frequency of four per year (two per year for major ions and trace elements) limits the ability to document waterquality variations, define relations with hydrologic variables, and assess processes that might cause variations in water quality. However, this level of data collection, if conducted systematically in an ongoing manner over time, can be useful for establishing baseline conditions to use as a reference for comparison to future water-quality conditions and to serve as a general measure of the ongoing status of conditions. As additional years of data are collected, the persistence of conditions can confirm either suitable water quality or an impaired status that might warrant resource-management actions. Also, with additional data, the ability to identify relations among various hydrologic variables might improve and allow better estimation of constituent loads or prediction of concentrations for a given flow condition or season. Ultimately, if systematic sampling continues for an extended number of years (10 or more), the data can be analyzed to detect statistically significant trends over time that might be attributable to factors such as climate or changing land- and water-use activities.

In addition to the periodic collection of water-quality samples, a subset of 26 sites was selected to provide a continuous record of water temperature during the warm- weather season (typically April through September). Because water temperature can vary substantially on both a daily and seasonal basis, measurements of temperature at the time of sample collection might not describe the full range of temperature that biota are exposed to in the stream. Continuous water-temperature data were considered important to assess the presence of potential thermal stress to aquatic biota, especially during low-flow conditions induced by either drought or irrigation withdrawals.

\section{Methods of Sample Collection, Processing, and Analysis}

Cross-sectional water samples were collected from multiple verticals across the stream using depth- and widthintegration methods described by Ward and Harr (1990), U.S. Geological Survey (variously dated), and Edwards and Glysson (1999). These methods provide a vertically and laterally discharge-weighted sample that is representative of the entire flow passing through the cross section of a stream. Sampling equipment consisted of standard USGS depth-integrating suspended-sediment samplers (DH-48, DH-81, D-74, D-77, and D-95). Samplers equipped with nylon nozzles and coated with a non-metallic epoxy paint or constructed of plastic were used to collect samples for analysis of trace elements. All samplers are designed to sample the water column isokinetically, whereby velocity flow paths are not distorted within the nozzle, thus allowing suspended particles to enter the samplecollection bottle at the same concentration as in the surrounding water.

Instantaneous streamflow at the time of sampling was determined at all stations, either by direct measurement or from stage-discharge rating tables (Rantz and others, 1982). Onsite measurements of $\mathrm{pH}$, specific conductance, and water temperature also were made during all sampling visits. Onsite sample processing, including withdrawal of representative subsamples from the composite cross-section sample, filtration of samples for dissolved constituents, and preservation of samples to prevent degradation prior to analysis, was performed according to procedures described by Ward and Harr (1990), Horowitz and others (1994), and U.S. Geological Survey (variously dated). Selected sample types were stabilized for analysis, using either acid preservative or chilling. Sample bottles, filters, and preservatives underwent systematic quality-control checks to verify cleanliness of material adequate to support analysis of environmental samples at low concentrations (such as $\mu \mathrm{g} / \mathrm{L}$, also referred to as "parts per billion").

Water samples were analyzed for chemical constituents (table 2) by the U.S. Geological Survey National Water Quality Laboratory (NWQL) in Denver, Colo. Dissolved concentrations of constituents were analyzed from filtered subsamples obtained by pumping the original sample water through a filter having a pore size of $0.45 \mu \mathrm{m}$ to remove particulate material. Total-recoverable concentrations of trace elements were determined from an unfiltered subsample that was digested in the 
laboratory with a solution of weak acid to liberate adsorbed and acid-soluble constituents from particulate material (Hoffman and others, 1996). Methods used by the NWQL to analyze samples from network sites are described by Fishman and Friedman (1989), Fishman (1993), McLain (1993), Garbarino and Struzeski (1998), and Jones and Garbarino (1999).

During 1999, the NWQL began implementing a new, statistically based convention for establishing reporting levels and for reporting low-concentration data (Childress and others, 1999). Quality-control data are collected at the laboratory on a continuing basis to determine long-term method detection levels (LT-MDLs) and laboratory reporting levels (LRLs). These values are reevaluated each year and, consequently, can change from year to year. The methods are designed to limit the possible occurrence of a false positive or false negative error to 1 percent or less. Accordingly, concentrations are reported as "less than" $(<)$ the LRL for samples in which the analyte either was not detected or did not pass identification criteria. Analytes that are detected at concentrations between the LT-MDL and LRL and that pass identification criteria are "estimated" and remarked with an "E" preceding the value. These values have less certainty than that for values reported without the "E" remark code.

Cross-sectional water samples of suspended sediment were analyzed for concentration and percent of suspended sediment finer than $0.062 \mathrm{~mm}$ in diameter (silt size and smaller) by the USGS sediment laboratory in Helena, Mont. (table 2). The methods for analysis of suspended sediment are described by Guy (1969) and Lambing and Dodge (1993).

A continuous record of water temperature was obtained at selected sites by use of an electronic temperature sensor that was placed in the stream where depth and velocity were adequate to generally represent the average temperature in the cross section. The temperature monitors were inspected on every visit to the site and checked for accuracy and drift according to methods described in Wagner and others (2000). Water-temperature data were transmitted by satellite telemetry and displayed in near real-time on the USGS NWIS Web site for Montana (http://waterdata.usgs.gov/mt/nwis/). This same Web site also displays real-time streamflow data for USGS gaging stations.

\section{Quality Assurance}

Procedures for sample collection and analysis used in this program incorporated practices designed to control, verify, and assess the quality of sample data. Methods and associated quality control for collection and field processing of water-quality samples are described by Ward and Harr (1990), Knapton and Nimick (1991), Horowitz and others (1994), U.S. Geological Survey (variously dated), and Edwards and Glysson (1999). Standard procedures used by the NWQL for internal sample handling and quality assurance are described by Friedmann and Erdmann (1982), Jones (1987), and Pritt and Raese (1995). Quality-assurance procedures used by the
Montana District sediment laboratory are described by Lambing and Dodge (1993).

The quality of analytical results reported for water-quality samples was evaluated by quality-control samples that were submitted from the field and analyzed concurrently in the laboratory with routine samples. These quality-control samples consisted of replicate stream samples and blank samples of certified trace-element-free deionized (DI) water, which provide information on the precision and contamination bias of the overall field and laboratory process. Each type of quality-control sample was submitted at a proportion of about 5 percent of the sample load, resulting in quality-control samples representing about 10 percent of the total number of water-quality samples.

In addition to quality-control samples submitted from the field, internal quality-assurance practices at the NWQL are performed systematically to provide quality control of analytical procedures (Pritt and Raese, 1995). These internal practices include use of calibration standards and analysis of standard reference water samples, replicate samples, DI-water blanks, or spiked samples at a proportion equivalent to about 10 percent of the sample load. The NWQL also participates in a blind-sample program administered by the USGS Branch of Quality Systems and in external evaluation studies with the U.S. Environmental Protection Agency (USEPA).

Replicate samples were used to identify the level of precision (reproducibility) of analytical results. Replicate samples are two or more samples considered essentially identical in composition. Precision of analytical results for replicate samples is affected by numerous sources of variability potentially introduced by both field and laboratory processes, including sample collection, sample processing and handling, and laboratory preparation and analysis. Analyses of replicate samples, therefore, can indicate the reproducibility of environmental data and provide information on the adequacy of procedures to produce consistent results. For chemical analyses, replicate samples were obtained in the field by splitting a single composite sample into two separate samples, which were each analyzed by the NWQL. Suspended-sediment replicates were obtained in the field by concurrently collecting two independent cross-sectional samples, which were then analyzed separately by the USGS sediment laboratory.

The precision of analytical results for a constituent can be determined by estimating a standard deviation of the differences in multiple sets of replicate sample pairs. The differences in concentration between each pair can be used to estimate a standard deviation according to the following equation (Taylor, 1987):

$$
S=\sqrt{\frac{\Sigma d^{2}}{2 k}}
$$

where

$S$ is the standard deviation of the difference in concentration between replicate analyses, 

$d \quad$ is the difference in concentration between each pair of replicate analyses, and
$k \quad$ is the number of pairs of replicate analyses.

Precision also can be expressed as a relative standard deviation (RSD), in percent, which is computed from the standard deviation and the mean concentration for all the replicate analyses. Expressing precision relative to a mean concentration standardizes comparison of precision among individual constituents. The RSD, in percent, is calculated according to the following equation (Taylor, 1987):

$$
R S D=\frac{S}{\bar{x}} \cdot 100
$$

where

$R S D$ is the relative standard deviation,

$S \quad$ is the standard deviation (equation 1), and

$\bar{x} \quad$ is the mean concentration of all replicate samples.

Analytical results for pairs of replicate samples are presented in table 13 (at the back of the report). The precision of replicate analytical results for each constituent, in terms of RSD, is listed in table 3. RSDs were based on the values reported in table 13. These values can have inconsistent levels of analytical resolution because LRLs for most constituents varied during the monitoring period (table 2). For RSD calculations, numbers that were reported as less than the LRL were assigned values of one-half of the LRL.

Generally, an RSD value of 20 percent or less represents an acceptable level of precision, although for concentrations near the LRL, the percent differences can be substantially larger and still be considered reasonable due to the limits of resolution (Taylor, 1987). For replicate samples analyzed in this study, most constituents had RSDs less than 20 percent, indicating that the overall process of sample collection, processing, and analysis produced consistent results. Many of the RSDs were near 10 percent or less. However, several exceptions were noted, including RSDs for the nutrient dissolved nitrite (47.8 percent) and the total-recoverable trace elements arsenic (26.3 percent), cadmium (61.0 percent), and chromium (26.2 percent). The high RSD for dissolved nitrite is largely an artifact of the predominance of values less than the LRL and the arbitrary substitution of one-half the LRL in the calculation. The RSD values in excess of 20 percent for total-recoverable arsenic and chromium also were affected primarily by concentrations less than the LRL and the arbitrary substitution of one-half the LRL in the calculation; however, two pairs of replicate samples had moderately large differences for total-recoverable arsenic at higher concentrations. In instances where values less than the LRL are common, calculation of an RSD is not quantitative and high RSDs do not necessarily imply poor analytical precision. The high RSD for totalrecoverable cadmium was entirely the result of an unusually large difference between one replicate pair (site 5, table 13), as almost all other replicate pairs had identical or similar results. If the one replicate pair is removed from the calculation, the RSD for total-recoverable cadmium is less than 15 percent and within acceptable precision. Because the large RSDs for four constituents resulted either from a predominance of concentrations near the LRL, or infrequent random occurrences of poor reproducibility, the precision data indicate overall acceptable performance of sample collection, processing, and analysis.

Blank samples of DI water obtained from the USGS laboratory in Ocala, Fla., were analyzed routinely to detect the presence and magnitude of contamination that potentially could bias analytical results. The particular type of blank sample routinely tested was a field blank. Field blanks are aliquots of DI water that are processed through the same sampling equipment used to collect stream samples. These blanks are then subjected to the same processing (sample splitting, filtration, preservation, transportation, and laboratory handling) as the stream samples. Blank samples were analyzed for the same constituents as the stream samples to identify whether any detectable concentrations exist. Analytical results for field blanks are presented in table 14 (at the back of the report).

A field blank with constituent concentrations equal to or less than the LRL for the analytical method indicates that the overall process of sample collection, processing, and laboratory analysis is free of significant contamination. If detectable concentrations in field blanks were equal to or greater than twice the LRL (typical measurement precision at the reporting level), the concentrations were noted during data review. Analytical results from the next field blank were evaluated for a consistent pattern of detectable concentrations for the same constituent(s) that might indicate systematic contamination. Sporadic, infrequent exceedances of twice the LRL probably represent random contamination or instrument calibration error that was not persistent in the process and which is not likely to cause significant positive bias in a long-term record of analytical results. However, if concentrations of a particular constituent exceed twice the LRL in field blanks from two consecutive field trips, blank samples are collected from individual components of the processing sequence and submitted for analysis in order to identify the source of contamination.

Constituent concentrations in the field blanks (table 14) were consistently less than the LRLs. Exceedances of twice the LRL occurred sporadically for dissolved calcium, total ammonia plus organic nitrogen, and total-recoverable zinc. Although 4 out of 31 blank analyses (about 13 percent) exceeded twice the LRL for calcium, no significant bias was likely introduced into the environmental data because concentrations in stream samples were all nearly two orders of magnitude greater than the LRL or largest value determined in the blanks. Only 1 out of the 33 blank analyses ( 3 percent) for ammonia plus organic nitrogen exceeded twice the LRL, which probably represented random contamination that would not be expected to bias the database. Two out of 30 of the blank analyses (about 7 percent) for total-recoverable zinc exceeded twice the LRL. The two blank samples (with concentrations of 6 and $8 \mu \mathrm{g} / \mathrm{L}$ ), which were submitted less than a 
month apart, indicated that analyses for zinc in stream samples collected near this time (May-June, 2002) may have had a small positive bias. Blank samples immediately preceding and following this period consistently had zinc concentrations less than the LRL of $1 \mu \mathrm{g} / \mathrm{L}$. Because the duration of the potential zinc contamination was short and the magnitude of the detectable concentrations was generally small relative to stream concentrations, the effect on the statistical characterization of zinc concentrations is considered insignificant. Consequently, the predominance of non-detectable concentrations in analytical results for field blanks indicate that the overall process of sample collection, processing, and laboratory analysis was consistently free of systematic contamination that could bias the results of stream samples collected for this program.

Table 3. Precision of analytical results for replicate samples, water years 1999-2003.

[Abbreviations: $\mathrm{CaCO}_{3}$, calcium carbonate; mm, millimeter; $\mathrm{N}$, nitrogen; $\mathrm{P}$, phosphorus]

\begin{tabular}{|c|c|c|}
\hline Constituent & Number of replicate pairs & $\begin{array}{c}\text { Relative standard deviation, } \\
\text { in percent }\end{array}$ \\
\hline Calcium, dissolved & 40 & 1.49 \\
\hline Magnesium, dissolved & 40 & 1.69 \\
\hline Potassium, dissolved & 34 & 3.90 \\
\hline Sodium, dissolved & 34 & 1.59 \\
\hline Alkalinity, dissolved as $\mathrm{CaCO}_{3}$ & 33 & 2.31 \\
\hline Chloride, dissolved & 34 & 2.32 \\
\hline Fluoride, dissolved & 34 & 6.31 \\
\hline Silica, dissolved & 34 & 3.08 \\
\hline Sulfate, dissolved & 34 & 1.64 \\
\hline Ammonia plus organic nitrogen, total as $\mathrm{N}$ & 41 & 8.62 \\
\hline Nitrite plus nitrate, dissolved as $\mathrm{N}$ & 41 & 7.15 \\
\hline Nitrite, dissolved as $\mathrm{N}$ & 41 & 47.8 \\
\hline Orthophosphate, dissolved as P & 41 & 6.90 \\
\hline Phosphorus, total & 41 & 6.18 \\
\hline Arsenic, total-recoverable & 31 & 26.3 \\
\hline Cadmium, total-recoverable & 31 & 61.0 \\
\hline Chromium, total-recoverable & 25 & 26.2 \\
\hline Copper, total-recoverable & 31 & 12.0 \\
\hline Lead, total-recoverable & 31 & 14.5 \\
\hline Nickel, total-recoverable & 25 & 13.0 \\
\hline Zinc, total-recoverable & 31 & 7.79 \\
\hline Sediment, suspended, percent finer than $0.062 \mathrm{~mm}$ & 36 & 6.46 \\
\hline Sediment, suspended & 37 & 8.31 \\
\hline
\end{tabular}




\section{Streamflow Characteristics}

Streamflow conditions can substantially affect processes that control water quality and the rate of constituent transport through the surface-water system. The large variability of streamflow, both day-to-day and year-to-year, can greatly affect the magnitude and duration of various water-quality conditions. Recognition of how streamflow characteristics during the sampling period compare to long-term hydrologic conditions can give insight to the reliability of water-quality assessments based on data collected during short-term monitoring periods. One means of obtaining a long-term perspective is by comparing streamflow statistics of the monitoring period with long-term statistics, if available, from streamflowgaging records.
Of the 38 sites in the statewide network, 36 had streamflow records of 10 years or more (table 1). At most sites having at least 10 years of record, mean annual streamflow was determined for the entire period of record (table 4) to represent long-term streamflow conditions. The long-term period of record for several sites that are downstream from large dams was limited to the period of record following dam completion in order to better represent the regulated streamflow patterns. The mean annual streamflow for the 5-year monitoring period (water years 1999-2003) at each site was determined to allow comparisons to long-term conditions. Mean annual streamflows at network sites during the 1999-2003 monitoring period, in percent of long-term mean annual streamflow, also are presented in table 4 .

Table 4. Streamflow characteristics for sites in the statewide monitoring network in Montana, water years 1999-2003 and long-term period of record.

[Abbreviation: $\mathrm{ft}^{3} / \mathrm{s}$, cubic feet per second. Symbol: --, no data]

\begin{tabular}{|c|c|c|c|c|c|c|c|}
\hline $\begin{array}{c}\text { Site } \\
\text { number } \\
\text { (fig. 1) }\end{array}$ & Station name & $\begin{array}{l}\text { Drainage } \\
\text { area } \\
\text { (square } \\
\text { miles) }\end{array}$ & $\begin{array}{l}\text { Mean annual } \\
\text { streamflow } \\
\text { for long-term } \\
\text { period of } \\
\text { record }^{1} \\
\left(\mathrm{ft}^{3} / \mathrm{s}\right)\end{array}$ & $\begin{array}{c}\text { Mean annual } \\
\text { streamflow, } \\
\text { water years } \\
\text { 1999-2003 } \\
\text { (ft } 3 \text { s) }\end{array}$ & $\begin{array}{c}\text { Percentage } \\
\text { of long-term } \\
\text { mean annual } \\
\text { streamflow for } \\
\text { water years } \\
1999-2003\end{array}$ & $\begin{array}{c}\text { Range in } \\
\text { daily mean } \\
\text { streamflow, } \\
\text { water years } \\
\begin{array}{c}1999-2003 \\
\left(\mathrm{ft}^{3} / \mathrm{s}\right)\end{array}\end{array}$ & $\begin{array}{c}\text { Range in } \\
\text { sampled } \\
\text { instantaneous } \\
\text { streamflow, } \\
\text { water years } \\
1999-2003 \\
\text { (ft } 3 / \mathrm{s})\end{array}$ \\
\hline 2 & $\begin{array}{l}\text { Jefferson River near } \\
\text { Three Forks }\end{array}$ & 9,532 & 2,020 & 1,440 & 71 & $110-11,300$ & $125-11,200$ \\
\hline 3 & Gallatin River at Logan & 1,795 & 1,070 & 815 & 76 & $190-5,480$ & $272-4,470$ \\
\hline 6 & $\begin{array}{l}\text { Dearborn River near } \\
\quad \text { Craig }\end{array}$ & 325 & 206 & 120 & 58 & $11-1,610$ & $13-799$ \\
\hline 7 & Sun River near Vaughn & 1,859 & 687 & 447 & 65 & $58-5,360$ & $170-3,550$ \\
\hline 8 & Teton River at Loma & 2,010 & -- & 28.8 & -- & $0-1,740$ & 2.4-314 \\
\hline 9 & $\begin{array}{l}\text { Judith River near mouth, } \\
\text { near Winifred }\end{array}$ & 2,731 & -- & 3250 & -- & $58-6,860$ & $62-616$ \\
\hline 10 & $\begin{array}{l}\text { Musselshell River at } \\
\text { Mosby }\end{array}$ & 7,846 & 268 & 30.9 & 12 & $0-1,330$ & $.03-180$ \\
\hline
\end{tabular}


Table 4. Streamflow characteristics for sites in the statewide monitoring network in Montana, water years 1999-2003 and long-term period of record.-Continued

\begin{tabular}{|c|c|c|c|c|c|c|c|}
\hline $\begin{array}{c}\text { Site } \\
\text { number } \\
\text { (fig. 1) }\end{array}$ & Station name & $\begin{array}{l}\text { Drainage } \\
\text { area } \\
\text { (square } \\
\text { miles) }\end{array}$ & $\begin{array}{c}\text { Mean annual } \\
\text { streamflow } \\
\text { for long-term } \\
\text { period of } \\
\text { record } \\
\left(\mathrm{ft}^{3} / \mathrm{s}\right)\end{array}$ & $\begin{array}{c}\text { Mean annual } \\
\text { streamflow, } \\
\text { water years } \\
1999-2003 \\
\left(\mathrm{ft}^{3} / \mathbf{s}\right)\end{array}$ & $\begin{array}{c}\text { Percentage } \\
\text { of long-term } \\
\text { mean annual } \\
\text { streamflow for } \\
\text { water years } \\
1999-2003\end{array}$ & $\begin{array}{c}\text { Range in } \\
\text { daily mean } \\
\text { streamflow, } \\
\text { water years } \\
\begin{array}{c}1999-2003 \\
\left(\mathrm{ft}^{3} / \mathrm{s}\right)\end{array}\end{array}$ & $\begin{array}{c}\text { Range in } \\
\text { sampled } \\
\text { instantaneous } \\
\text { streamflow, } \\
\text { water years } \\
\begin{array}{c}1999-2003 \\
\left(\mathrm{ft}^{3} / \mathbf{s}\right)\end{array}\end{array}$ \\
\hline \multicolumn{8}{|c|}{ Missouri River basin—Continued } \\
\hline 14 & $\begin{array}{l}\text { Missouri River near } \\
\text { Culbertson }\end{array}$ & 91,557 & ${ }^{2} 10,200$ & 8,170 & 80 & $3,870-22,400$ & $4,200-21,300$ \\
\hline \multicolumn{8}{|c|}{ Yellowstone River basin } \\
\hline 15 & $\begin{array}{l}\text { Yellowstone River near } \\
\text { Livingston }\end{array}$ & 3,551 & 3,750 & 3,320 & 89 & $750-24,800$ & $1,070-18,900$ \\
\hline 16 & $\begin{array}{l}\text { Shields River near Liv- } \\
\text { ingston }\end{array}$ & 852 & 279 & 167 & 60 & $23-1,670$ & $35-1,110$ \\
\hline 17 & $\begin{array}{l}\text { Boulder River at Big } \\
\text { Timber }\end{array}$ & 523 & 566 & 415 & 73 & $14-5,370$ & $18-4,080$ \\
\hline 18 & $\begin{array}{l}\text { Stillwater River near } \\
\text { Absarokee }\end{array}$ & 975 & 938 & ${ }^{3} 672$ & 72 & $130-6,440$ & $204-5,300$ \\
\hline 19 & $\begin{array}{l}\text { Clarks Fork Yellowstone } \\
\text { River at Edgar }\end{array}$ & 2,022 & 1,030 & 896 & 87 & $79-8,760$ & $100-8,080$ \\
\hline 20 & $\begin{array}{l}\text { Bighorn River above } \\
\text { Tullock Creek, near } \\
\text { Bighorn }\end{array}$ & 22,414 & 23,490 & 2,710 & 78 & $953-12,200$ & $1,450-9,340$ \\
\hline 21 & $\begin{array}{l}\text { Rosebud Creek near } \\
\text { Rosebud }\end{array}$ & 1,302 & 28.1 & 11.2 & 40 & $0-500$ & $.18-176$ \\
\hline 22 & $\begin{array}{l}\text { Tongue River at Miles } \\
\text { City }\end{array}$ & 5,379 & 409 & 244 & 60 & $6.5-4,000$ & $6.8-2,740$ \\
\hline 23 & Powder River near Locate & 13,068 & 576 & 345 & 60 & $.1-4,800$ & $.2-5,170$ \\
\hline 24 & $\begin{array}{l}\text { Yellowstone River near } \\
\text { Sidney }\end{array}$ & 69,083 & ${ }^{2} 12,400$ & 8,610 & 69 & $1,010-53,500$ & $1,120-52,300$ \\
\hline \multicolumn{8}{|c|}{ Columbia River basin } \\
\hline 25 & $\begin{array}{l}\text { Kootenai River below } \\
\text { Libby Dam, near Libby }\end{array}$ & 8,985 & ${ }^{2} 11,150$ & 10,100 & 91 & $3,680-39,700$ & $3,860-27,000$ \\
\hline 26 & Fisher River near Libby & 838 & 488 & 440 & 90 & $52-6,330$ & $53-4,130$ \\
\hline 27 & Yaak River near Troy & 766 & 866 & 693 & 80 & $49-10,900$ & $49-7,130$ \\
\hline 28 & $\begin{array}{l}\text { Little Blackfoot River } \\
\text { near Garrison }\end{array}$ & 407 & 152 & 103 & 68 & $10-849$ & $15-852$ \\
\hline 29 & Rock Creek near Clinton & 885 & 521 & 412 & 79 & $38-3,750$ & $149-3,580$ \\
\hline 30 & $\begin{array}{l}\text { Clark Fork at Turah } \\
\text { Bridge, near Bonner }\end{array}$ & 3,641 & 1,200 & 1,050 & 88 & $200-6,790$ & $287-6,200$ \\
\hline 31 & $\begin{array}{l}\text { Blackfoot River near } \\
\text { Bonner }\end{array}$ & 2,290 & 1,580 & 1,340 & 85 & $250-8,800$ & $450-8,990$ \\
\hline 32 & $\begin{array}{l}\text { Bitterroot River near } \\
\text { Missoula }\end{array}$ & 2,814 & 2,450 & 2,050 & 84 & $400-21,300$ & $482-17,200$ \\
\hline 33 & Clark Fork at St. Regis & 10,709 & 7,180 & 6,120 & 85 & $1,200-43,700$ & $1,660-35,300$ \\
\hline
\end{tabular}


Table 4. Streamflow characteristics for sites in the statewide monitoring network in Montana, water years 1999-2003 and long-term period of record.-Continued

\begin{tabular}{|c|c|c|c|c|c|c|c|}
\hline $\begin{array}{c}\text { Site } \\
\text { number } \\
\text { (fig. 1) }\end{array}$ & Station name & $\begin{array}{l}\text { Drainage } \\
\text { area } \\
\text { (square } \\
\text { miles) }\end{array}$ & $\begin{array}{c}\text { Mean annual } \\
\text { streamflow } \\
\text { for long-term } \\
\text { period of } \\
\text { record } \\
\text { (ft's) }\end{array}$ & $\begin{array}{c}\text { Mean annual } \\
\text { streamflow, } \\
\text { water years } \\
1999-2003 \\
\left(\mathrm{ft}^{3} / \mathrm{s}\right)\end{array}$ & $\begin{array}{c}\text { Percentage } \\
\text { of long-term } \\
\text { mean annual } \\
\text { streamflow for } \\
\text { water years } \\
1999-2003\end{array}$ & $\begin{array}{c}\text { Range in } \\
\text { daily mean } \\
\text { streamflow, } \\
\text { water years } \\
\text { 1999-2003 } \\
\left(\mathrm{ft}^{3} / \mathrm{s}\right)\end{array}$ & $\begin{array}{c}\text { Range in } \\
\text { sampled } \\
\text { instantaneous } \\
\text { streamflow, } \\
\text { water years } \\
1999-2003 \\
\left(\mathrm{ft}^{3} / \mathrm{s}\right)\end{array}$ \\
\hline \multicolumn{8}{|c|}{ Columbia River basin —Continued } \\
\hline 34 & $\begin{array}{l}\text { North Fork Flathead } \\
\text { River near Columbia } \\
\text { Falls }\end{array}$ & 1,548 & 3,000 & 2,670 & 89 & $270-21,800$ & $495-19,700$ \\
\hline 35 & $\begin{array}{l}\text { Middle Fork Flathead } \\
\text { River near West } \\
\text { Glacier }\end{array}$ & 1,128 & 2,880 & 2,530 & 88 & $207-21,700$ & $406-20,500$ \\
\hline 36 & $\begin{array}{l}\text { Whitefish River near } \\
\text { Kalispell }\end{array}$ & 170 & 187 & 146 & 78 & $24-809$ & $31-717$ \\
\hline 37 & Swan River near Bigfork & 671 & 1,160 & 935 & 81 & $250-5,220$ & $289-3,580$ \\
\hline 38 & Flathead River at Perma & 8,795 & 11,610 & 10,100 & 87 & $3,600-47,200$ & $4,090-40,400$ \\
\hline
\end{tabular}

${ }^{1}$ Long-term period of record is presented in table 1.

${ }^{2}$ Mean annual streamflow was calculated for period of record after construction of large dam on mainstem or major tributary.

${ }^{3}$ Mean annual streamflow is based on fewer than 5 years.

During water years 1999-2003, most of Montana had less than average precipitation (U.S. Geological Survey, issued annually). This persistent pattern of below-normal precipitation resulted in below-normal streamflows across the network. The mean annual streamflow for the 5-year monitoring period compared to long-term periods of record ranged from about 12 percent at Musselshell River at Mosby to 91 percent at Kootenai River below Libby Dam (table 4). Streamflows at sites in the Missouri River basin were the most depleted relative to long-term conditions, with the 5-year mean annual streamflows ranging from 12 to 80 percent of long-term means. In the Yellowstone River basin, the 5-year mean annual streamflows ranged from about 40 to 89 percent of long-term means. The least-affected sites were those in the Columbia River basin, with 5-year mean annual streamflows ranging from about 68 to 91 percent of long-term means.

In addition to a general assessment of mean annual streamflow, the magnitudes of peak flows that occurred during the sampling period are important for characterizing water quality because they represent the condition during which most of the suspended sediment and associated chemical constituents typically are transported through a river system. Climatic conditions not only affect the volume of streamflow annually discharged from a river basin, but also the duration and magnitude of peak flows. To illustrate general differences in daily streamflow patterns between short-term and long-term periods (fig. 2), annual hydrographs are shown depicting mean daily streamflows for both the 5-year monitoring period and the long-term period of record for representative sites in each of the three major river basins.

Mean daily streamflow during water years 1999-2003 at selected sites in the Missouri River basin (Missouri River at Toston) and Yellowstone River basin (Yellowstone River near Sidney) show that peak flows, on average, occurred earlier in the year and were substantially less in both magnitude and duration than long-term mean daily peak flows. The representative site for the Columbia River basin (Clark Fork at St. Regis) indicates that the magnitude of peak flow during 1999-2003 was slightly greater than the long-term mean; however, the duration of the 1999-2003 peak flow was less than the long-term mean. Overall, the hydrologic conditions during 1999-2003 were more similar to long-term conditions in the Columbia River basin than in the Missouri and Yellowstone River basins.

The implications of less-than-normal streamflow on water quality during the monitoring period cannot be directly quantified. However, relative comparisons between shortterm and long-term streamflow conditions can provide some perspective when evaluating water-quality characteristics. For example, constituents associated with erosional processes, such as suspended sediment, can exhibit relatively low concentrations in short-term sampling programs conducted during years of below-normal streamflow. This under-representation of long-term sediment transport also could result in relatively lower concentrations for sediment-associated constituents, such as nutrients and trace elements, than might be expected 

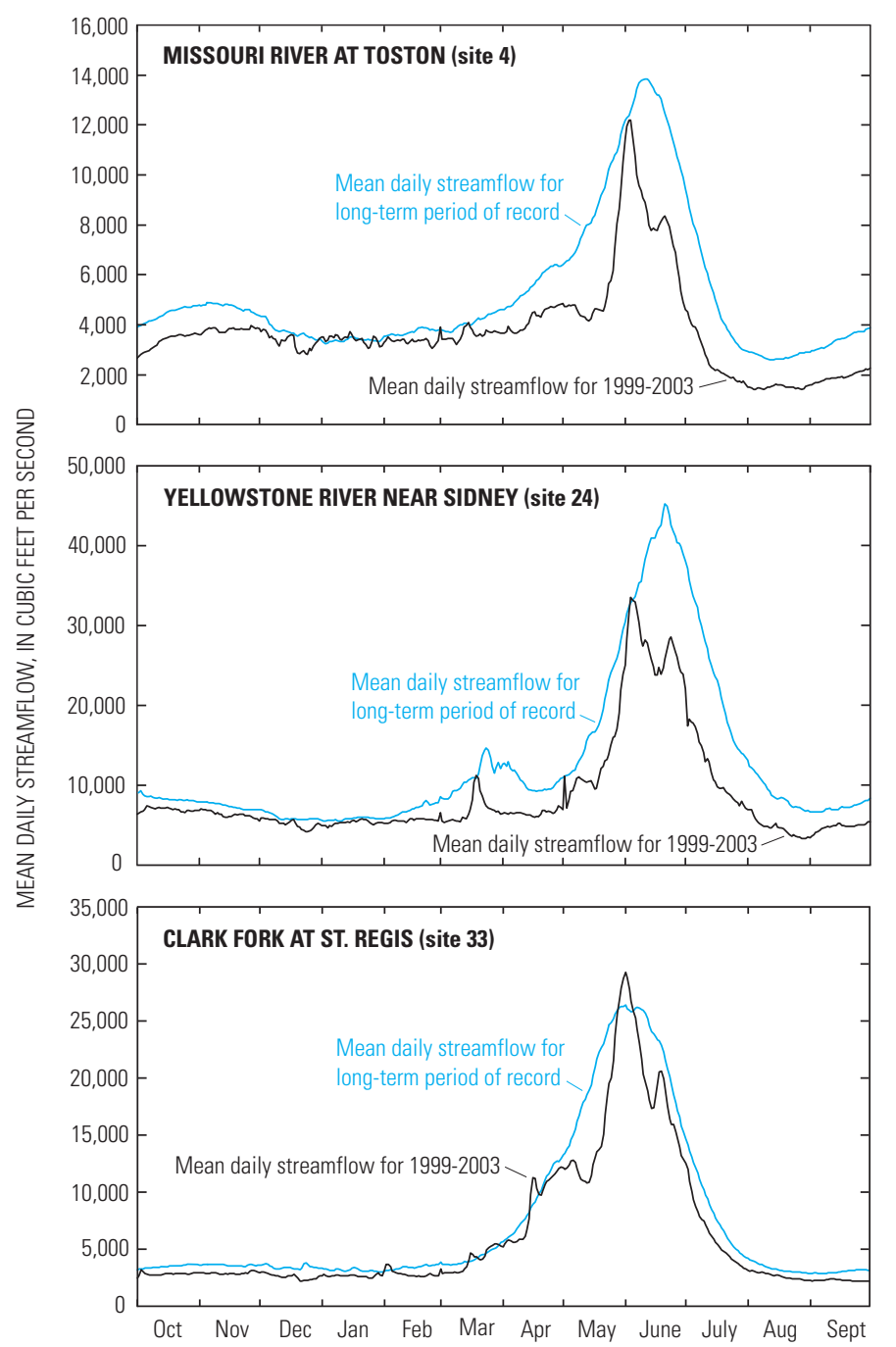

Figure 2. Annual hydrographs of mean daily streamflow during water years 1999-2003 and long-term mean daily streamflow for Missouri River at Toston (69 years of record), Yellowstone River near Sidney ( 90 years of record), and Clark Fork at St. Regis (87 years of record), Montana.

during conditions of increased streamflow. In contrast, properties such as water temperature may increase during belownormal flow conditions due to decreased stream depths and water velocities. Because constituent loads are directly related to streamflow, estimated mean annual loads transported during the monitoring period are likely to have been somewhat less than long-term mean annual loads.

\section{Water-Quality Characteristics}

All USGS data collected for the constituents analyzed (table 2) for sites in the statewide monitoring network during water years 1999-2003 are statistically summarized in table 15 (at the back of the report). These summaries also include any additional data that were collected for these sites as part of other USGS sampling programs during the monitoring period. Variable precision of values reported for selected constituents (table 15) results from the different LRLs (table 2) for the analytical methods available at the time of sample collection.

The statistical distributions of values for selected stream properties or constituent concentrations at each site in the statewide network also are illustrated using boxplots. The boxplot gives a graphical display of the minimum and maximum values along with selected percentiles $\left(10^{\text {th }}, 25^{\text {th }}, 50^{\text {th }}, 75^{\text {th }}\right.$, and $90^{\text {th }}$ ) that describe the percentage of samples having values equal to or less than an indicated value. The box encompasses the central 50 percent of the data (from the $25^{\text {th }}$ to $75^{\text {th }}$ percentiles) and represents the central tendency of values for the site. The $50^{\text {th }}$ percentile is the median. The median (unlike the mean) is not affected by the magnitude of extreme values that occur infrequently. The remaining values that fall outside the central 50 percent of data are shown as extensions above or below the box to the minimum and maximum values. Some boxes do not have extensions or are compressed to one or two horizontal lines, indicating a preponderance of equal values.

For selected stream properties and constituents, boxplots for sites in the statewide network are shown collectively in one figure to provide an overview. Boxplots are grouped by major river basin to allow geographic separation of general water-quality patterns. By collectively presenting data for all network sites in each figure, both the individual site characteristics and relative differences between sites are shown. With the exception of water temperature, the boxplots represent the distribution of instantaneous values at the time of sampling; consequently, conditions between sampling visits are not fully represented by the boxplots. Boxplots for sites within each basin or subbasin are presented in a downstream direction from left to right.

Various water-quality standards or recommended guidelines for protecting human health, freshwater aquatic life, and agricultural irrigation also are presented for selected properties and constituents to indicate the general percentage of sample values that exceeded the indicated standards or guidelines. Standards represent legally enforceable State law, whereas guidelines are recommended maximum values that indicate potential thresholds which, if exceeded by either a large margin or for extended periods of time, might result in potential impairment to the specified water use. Therefore, comparisons of values from periodically collected samples to the water-quality standards or guidelines shown on the graphs are intended only as a general reference to potential risk of impairment.

For plotting purposes, adjustments to the original data were sometimes necessary to account for concentrations reported as censored values (values less than the LRL). During the 5-year monitoring period, several LRLs were used by the laboratory for most constituents (table 2) as a result of differing analytical methods or improvements in analytical methods that usually provided increasingly lower LRLs. In most cases, censored values were substituted with a value equal to one- 
half the maximum LRL. Because censored values represent low concentrations, the effect of using one-half of the LRL on the statistical distribution of values usually is negligible for those constituents whose environmental concentrations are commonly greater than the censoring level. However, for some constituents that routinely occur at low concentrations and have a large percentage of the analytical results censored, the degree of variation in the LRLs during the monitoring period could be large enough that adjusting censored values to one-half the maximum LRL could affect the comparisons of data to water-quality standards and guidelines or misrepresent likely environmental concentrations. In these instances, where the range of variation in the LRLs during the monitoring period was large (for example, total-recoverable cadmium, copper, and zinc), the values censored at the higher LRLs cannot adequately be adjusted using one-half the censoring level because the resulting values may not reasonably represent actual environmental concentrations. Therefore, for constituents having reported values censored at high LRLs, those values were eliminated from the data set for the site prior to plotting the boxplot. Estimated values (values qualified with an "E" remark code) were plotted directly, but they also have a lower level of certainty than uncensored values.

Although selected censored data were removed from the data sets for the boxplots, all censored data were retained in the statistical summaries (table 15) to represent the full set of originally reported values stored in the USGS database. Thus, in a few instances, the percentile values for the modified data sets displayed by the boxplots do not necessarily match those shown in table 15. The modification to the boxplot data sets primarily affects only the low end of the data range. The elimination of ambiguous analytical results in the boxplots is intended to provide a more meaningful basis for comparison of values between sites or to water-quality standards and guidelines.

\section{Stream Properties}

Various stream properties, such as streamflow, $\mathrm{pH}$, specific conductance, and water temperature are important measures related to water quality because they either influence instream processes, such as chemical or biological reactions and transport, or they provide an indication of general waterquality characteristics that can be compared to recommended guidelines or used to estimate values of related constituents. During each sampling visit, streamflow, $\mathrm{pH}$, specific conductance, and water temperature were determined onsite to represent conditions at the time of sampling. Values for these stream properties are statistically summarized (table 15) for each site in the statewide network. Discussions and graphical presentation of data for selected stream properties measured at network sites are presented in the following sections for $\mathrm{pH}$, specific conductance, and water temperature.
$\mathrm{pH}$

The $\mathrm{pH}$ of stream water typically ranges from about 6.5 to 8.5 (Hem, 1985). However, many natural and anthropogenic activities can affect the $\mathrm{pH}$ of a stream. In acidic waters $(\mathrm{pH}$ less than 7), the solubility of many trace elements increases, thereby enhancing the potential for dissolution of particulatebound elements into a dissolved form that aquatic organisms can uptake more readily (Stumm and Morgan, 1996). Natural geothermal waters or acid drainage from areas affected by historical mining activities are potential sources of low $\mathrm{pH}$. Conversely, various geologic materials or photosynthesis by aquatic plants can cause increases in pH. Diel (24-hour) fluctuation in $\mathrm{pH}$ occurs in many streams in response to daily photosynthetic cycles of plants, with increasing values during daylight hours and decreasing values during the night. Maximum $\mathrm{pH}$ values commonly occur during summer as the result of photosynthesis.

The statistical distribution of $\mathrm{pH}$ values measured at network sites during water years 1999-2003 is shown in figure 3. Across the network, $\mathrm{pH}$ values ranged from 7.0 to 9.5 (table 15). Several sites in the Columbia River basin had minimum $\mathrm{pH}$ values near 7.0; only one site in the Missouri River basin (Peoples Creek near Dodson) and one site in the Columbia River basin (Kootenai River below Libby Dam) had maximum $\mathrm{pH}$ values greater than 9.0. Almost every site in the network had a median $\mathrm{pH}$ greater than 8.0. Peoples Creek near Dodson and Poplar River near Poplar both had median $\mathrm{pH}$ values of 8.7, which were the highest medians in the network. Only two sites had median $\mathrm{pH}$ less than 8.0, and both were in the Columbia River basin (Yaak River near Troy and Bitterroot River near Missoula). In general, $\mathrm{pH}$ values at most sites were within the expected range of natural values; extremely high or low values were not consistently measured.

In the Missouri River basin, $\mathrm{pH}$ values ranged from 7.4 at Prickly Pear Creek near Clancy to 9.3 at Peoples Creek near Dodson. Median $\mathrm{pH}$ values ranged from 8.1 at Prickly Pear Creek near Clancy to 8.7 at Peoples Creek near Dodson and Poplar River near Poplar (fig. 3, table 15). Prickly Pear Creek near Clancy had a distinctly lower $\mathrm{pH}$ distribution compared to the other sites in the Missouri River basin. This creek is a relatively small tributary that drains mountains and foothills that historically were mined for metals in some areas. Even though the $\mathrm{pH}$ values in Prickly Pear Creek commonly were lower than at the other network sites in the Missouri River basin, they were still within the typical range of natural waters.

In the Yellowstone River basin, $\mathrm{pH}$ values ranged from 7.3 at Yellowstone River near Livingston and Boulder River at Big Timber to 8.9 at Rosebud Creek near Rosebud. Median pH values varied over a relatively narrow range from 8.0 at Yellowstone River near Livingston to 8.6 at Bighorn River near Bighorn. Unusual variations or extreme values in $\mathrm{pH}$ are not apparent in the boxplots for the Yellowstone River basin.

In the Columbia River basin, $\mathrm{pH}$ values ranged from 7.0 at Kootenai River below Libby Dam and Middle Fork Flathead River near West Glacier to 9.5 at Kootenai River below 


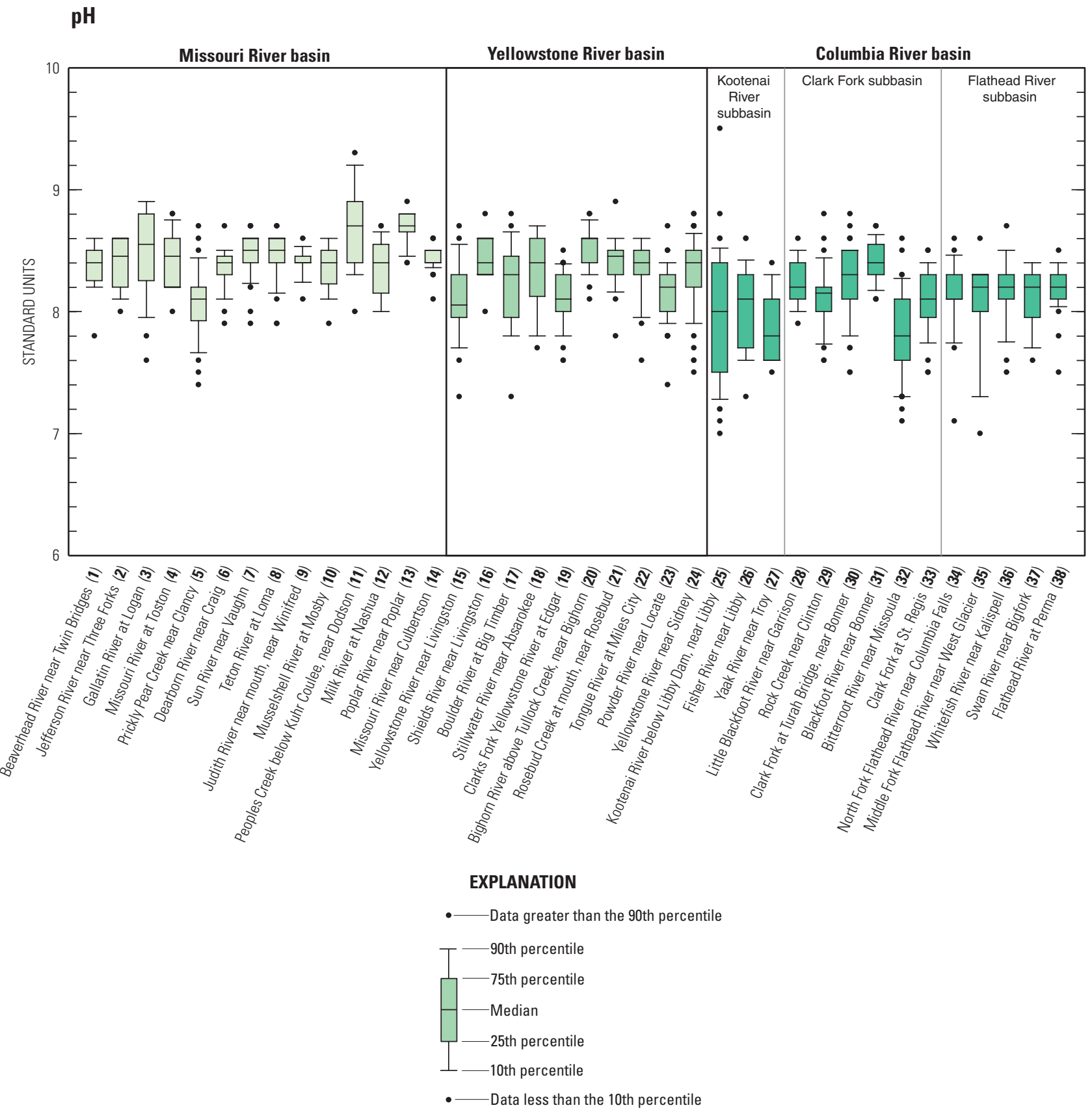

Note: When a data set contains multiple equal values, two or more of the percentile lines can overlap and result in a compressed plot

Figure 3. Statistical distribution of pH values at network sites in Montana, water years 1999-2003. Site number presented after station name (fig. 1, table 1). 
Libby Dam. Median pH values ranged from 7.8 at Yaak River near Troy and Bitterroot River near Missoula to 8.4 at the Blackfoot River near Bonner. Values of $\mathrm{pH}$ at Kootenai River below Libby Dam had the largest range of variation (2.5 units) among all network sites, possibly due to the discharge of water from Lake Koocanusa from varying depths or in response to algal productivity in the lake.

\section{Specific Conductance}

Specific conductance is a commonly measured property that represents the water's capacity to conduct an electrical current. The measurement provides an approximation of the concentration of dissolved solids in the water, which are composed largely of electrically charged ions. At many sites, specific conductance can be mathematically related to either the dissolved-solids concentration or the concentration of individual major ions. Therefore, specific conductance can serve as a surrogate measure of dissolved solids and be used to estimate major-ion concentrations where sufficient data have been previously obtained to define the relation for a site.

The statistical distribution of specific conductance values measured at network sites during water years 1999-2003 is shown in figure 4 . Also shown is a general irrigation guideline for specific conductance of $1,500 \mu \mathrm{S} / \mathrm{cm}$, which represents the lower end of a range $(1,500-3,000 \mu \mathrm{S} / \mathrm{cm})$ of specific conductance values that might have adverse effects on many crops (U.S. Department of Agriculture, 2002). In the Yellowstone River basin, State of Montana numeric standards for specific conductance have been established for the Rosebud Creek, Tongue River, and Powder River watersheds (Montana Department of Environmental Quality, 2003). In the Rosebud Creek and Tongue River mainstems, the monthly average specific conductance in the mainstems of these streams is not to exceed $1,000 \mu \mathrm{S} / \mathrm{cm}$ and at no time is a discrete sample value to exceed 1,500 $\mu \mathrm{S} / \mathrm{cm}$ during the irrigation season (March 2 through October 31). For the Powder River mainstem during the irrigation season, the specific conductance standards are $2,000 \mu \mathrm{S} / \mathrm{cm}$ for a monthly average and 2,500 $\mu \mathrm{S} / \mathrm{cm}$ for a discrete sample. Somewhat higher values are designated for these mainstems during the non-irrigation season (November 1 through March 1), with specific conductance standards ranging from 1,500-2,500 $\mathrm{SS} / \mathrm{cm}$ for monthly averages, and 2,500 $\mu \mathrm{S} / \mathrm{cm}$ for discrete samples. Because most of the samples collected in this program were obtained during the MarchOctober period, the numeric standards applicable to discrete samples collected during the irrigation season are shown in figure 4 for the sites on Rosebud Creek, Tongue River, and Powder River.

Across the network, specific-conductance values varied widely, ranging from 32 to $6,940 \mu \mathrm{S} / \mathrm{cm}$ (table 15). In the Missouri and Yellowstone River basins, notably higher values of specific conductance were measured at sites in the lower parts of the basin compared to those in the upper parts that are closer to mountain headwater streams. This spatial pattern presumably reflects precipitation differences, with wetter areas in the mountains and more arid areas in the prairies, which can affect the weathering of rocks and accumulation of soluble salts at or near the surface. In contrast, all sites in the Columbia River basin had consistently low specific conductance relative to the other two major river basins.

In the Missouri River basin, the specific-conductance values ranged from $112 \mu \mathrm{S} / \mathrm{cm}$ at Prickly Pear Creek near Clancy to $6,940 \mu \mathrm{S} / \mathrm{cm}$ at Musselshell River at Mosby. Median specific conductance ranged from $257 \mu \mathrm{S} / \mathrm{cm}$ at Prickly Pear Creek near Clancy to 2,480 $\mu \mathrm{S} / \mathrm{cm}$ at Musselshell River at Mosby (fig. 4, table 15). A distinct increase in specific conductance is evident from the Sun River near Vaughn downstream to Poplar River near Poplar. Musselshell River at Mosby had the largest range in values. The median specific conductance $(585 \mu \mathrm{S} / \mathrm{cm})$ at the lower-mainstem site at Missouri River near Culbertson is substantially lower than at the tributaries in the lower part of the basin.

Most values measured at Musselshell River at Mosby exceeded the general irrigation guideline of $1,500 \mu \mathrm{S} / \mathrm{cm}$, and often by a large amount, presumably due, at least in part, to the low streamflows during the monitoring period (table 4). Specific conductance exceeded the irrigation guideline in more than 25 percent of the samples at Peoples Creek near Dodson and Poplar River near Poplar, and occasionally at Milk River at Nashua (fig. 4). None of the other sites in the Missouri River basin had specific-conductance values that exceeded the general irrigation guideline.

In the Yellowstone River basin, specific-conductance values ranged from $42 \mu \mathrm{S} / \mathrm{cm}$ at Stillwater River near Absarokee to $3,770 \mu \mathrm{S} / \mathrm{cm}$ at Rosebud Creek near Rosebud. Median specific conductance ranged from $124 \mu \mathrm{S} / \mathrm{cm}$ at Stillwater River near Absarokee to about 2,000 $\mu \mathrm{S} / \mathrm{cm}$ at both Rosebud Creek near Rosebud and Powder River near Locate (fig. 4, table 15). Specific conductance generally increased downstream from the Clarks Fork Yellowstone River; however, both Rosebud Creek near Rosebud and Powder River near Locate had distinctly higher values and larger ranges of specific conductance compared to other sites in the basin.

The median specific conductance at Rosebud Creek near Rosebud and Powder River near Locate exceeded the general irrigation guideline of $1,500 \mu \mathrm{S} / \mathrm{cm}$, whereas only one sample at Tongue River at Miles City exceeded the guideline (fig. 4). The numeric standard for Rosebud Creek and Tongue River $(1,500 \mu \mathrm{S} / \mathrm{cm})$ is the same as the general irrigation guideline, thus the pattern of exceedances is the same. Fewer than 25 percent of the samples from Powder River near Locate exceeded the numeric standard for the Powder River mainstem $(2,500 \mu \mathrm{S} / \mathrm{cm})$, which is higher than the general irrigation guideline. All other specific-conductance values in the Yellowstone River basin were less than the general irrigation guideline.

In the Columbia River basin, specific-conductance values ranged from $32 \mu \mathrm{S} / \mathrm{cm}$ at Yaak River near Troy to $416 \mu \mathrm{S} / \mathrm{cm}$ at Clark Fork at Turah Bridge. All measured values of specific conductance were low relative to the other two basins, with medians ranging from $76 \mu \mathrm{S} / \mathrm{cm}$ at Yaak River near Troy to 


\section{SPECIFIC CONDUCTANCE}

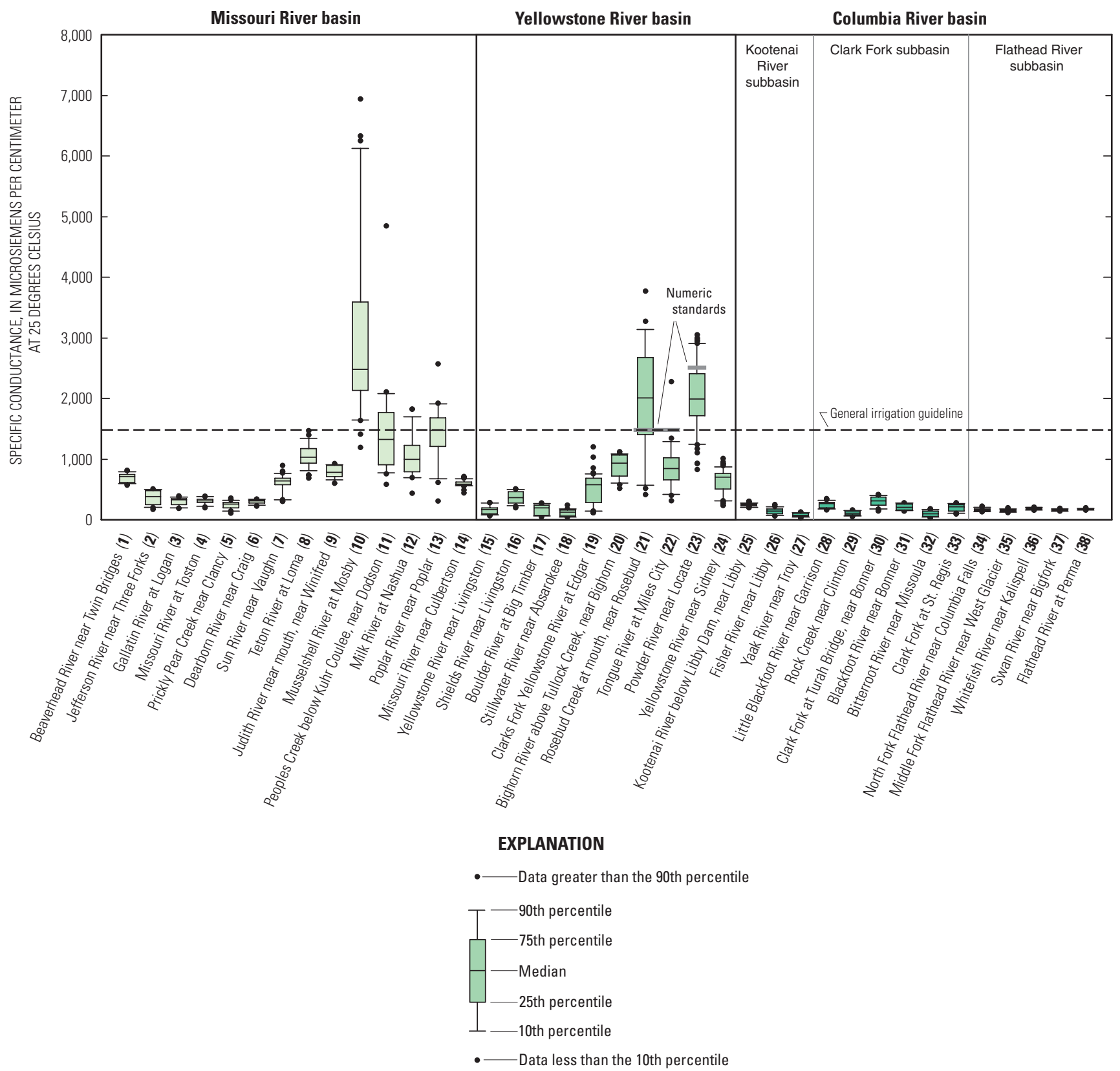

Note: When a data set contains multiple equal values, two or more of the percentile lines can overlap and result in a compressed plot

Figure 4. Statistical distribution of specific-conductance values at network sites in Montana, water years 1999-2003. Site number presented after station name (fig. 1, table 1). The State of Montana numeric standards (Montana Department of Environmental Quality, 2003) of 1,500 and 2,500 microsiemens per centimeter at 25 degrees Celsius represent the basin-specific maximum allowable values for samples collected during the irrigation season, March 2 through 0 ctober 31 . The U.S. Department of Agriculture general irrigation guideline (2002) is 1,500 microsiemens per centimeter at 25 degrees Celsius. 
$317 \mu \mathrm{S} / \mathrm{cm}$ at Clark Fork at Turah Bridge. Specific conductance did not substantially vary at individual sites or between sites, and all values were well below the general irrigation guideline (fig. 4).

\section{Water Temperature}

Water temperature is an important stream property that affects many of the beneficial uses of water. Elevated water temperatures can accelerate biodegradation of organic material, which consumes oxygen. Further exacerbating the effect of elevated temperature on oxygen is the fact that oxygen becomes less soluble as water temperature increases. Sustained temperature changes in water bodies can affect aquatic communities by altering the composition or geographic distribution of phytoplankton and aquatic invertebrate species. Similarly, elevated water temperatures can cause a shift from a cold-water to warm-water fishery through either direct lethality, reduction in activity, or reduced reproduction (U.S. Environmental Protection Agency, 1986).

Instantaneous water temperature was measured at the time of each sampling visit (table 15). Because water temperature can vary substantially, depending on time of day or season of the year, comparison of instantaneous values among sites is less informative than comparison of daily mean water temperatures obtained from continuous recorders that measure the duration and magnitude of daily temperature variations.

Not all sites were equipped with instruments to continuously record water temperature; therefore, daily mean water temperatures are not available for some sites. For 26 sites equipped with continuous temperature monitors, data typically were recorded seasonally (April through September). Several sites had water-temperature recorders added after 1999; thus, their period of record is less than 5 years. Because the effect of water temperature on aquatic biota is greatest during periods of warm weather (period of greatest thermal stress), the statistical distribution of daily mean water temperatures at selected sites for the summer months June, July, and August are shown on figure 5 .

Water-temperature thresholds for impairment vary based on the specific water-use classification of a stream (Montana Department of Environmental Quality, 2002a). Within each classification (table 1), various criteria are cited for allowable temperature increases or decreases relative to naturally occurring water temperatures. Assessment of complex temperature standards is beyond the scope of this report. However, the daily mean water temperatures available for selected network sites can be compared to the two maximum allowable temperatures cited for classifications that prescribe maintenance of salmonid or non-salmonid fishes and associated aquatic life. For simplicity, salmonid and non-salmonid categories will be described as "cold water," and "warm water," respectively. Cold-water guidelines apply to classifications A-1, B-1, and B-2 (cold water, marginal); warm-water guidelines apply to classifications B-3 and C-3 (table 1). Therefore, as general guidelines, water temperatures greater than $67.0^{\circ} \mathrm{F}\left(19.4{ }^{\circ} \mathrm{C}\right)$ might adversely affect cold-water aquatic life and water temperatures greater than $80.0^{\circ} \mathrm{F}\left(26.7^{\circ} \mathrm{C}\right)$ might adversely affect warm-water aquatic life (Montana Department of Environmental Quality, 2002b). Although these values are intended only to facilitate relative comparisons across the statewide network of sites, they closely match the maximum weekly average summer water temperatures recommended by the U.S. Environmental Protection Agency (1986) to prevent adverse effects on the growth of juveniles and adults of various cold-water and warm-water fish species.

Summer daily mean water temperatures varied widely across the network, ranging from a minimum of $4.0^{\circ} \mathrm{C}$ at Yaak River near Troy to a maximum of $29.5^{\circ} \mathrm{C}$ at Teton River at Loma and Tongue River at Miles City (fig. 5). Median values of daily mean water temperatures also varied widely, with the lowest median $\left(12.5^{\circ} \mathrm{C}\right)$ recorded at Kootenai River below Libby Dam and the highest median $\left(23.0^{\circ} \mathrm{C}\right)$ recorded at Poplar River near Poplar and Tongue River at Miles City (fig. 5). In general, sites in the Columbia River basin tended to have the lowest water temperatures, whereas sites in the Missouri River basin commonly had the highest; however, the lack of continuous temperature recorders at some sites makes this comparison incomplete.

In the Missouri River basin, summer daily mean water temperatures at sites with continuous temperature recorders ranged from $4.5^{\circ} \mathrm{C}$ at Dearborn River near Craig to $29.5^{\circ} \mathrm{C}$ at Teton River at Loma. Median summer daily mean water temperatures ranged from $17.0^{\circ} \mathrm{C}$ at Dearborn River near Craig to $23.0^{\circ} \mathrm{C}$ at Poplar River near Poplar (fig. 5).

Four sites (Jefferson River near Three Forks, Missouri River at Toston, Judith River near Winifred, and Poplar River near Poplar) that represent cold-water (C) or cold-water marginal (CM) fisheries had summer daily mean temperatures that exceeded the cold-water guideline of $19.4{ }^{\circ} \mathrm{C}$ on 50 percent or more of the days. Both the Judith and Poplar River sites, which represent cold-water marginal fisheries (CM), exceeded the cold-water guideline on about 75 percent or more of the days, and their maximum values exceeded the warm-water guidelines of $26.7^{\circ} \mathrm{C}$. Three sites (Beaverhead River near Twin Bridges, Gallatin River at Logan, and Dearborn River near Craig) that represent cold-water (C) fisheries exceeded the cold-water guideline on about 25 percent of the days. For the remaining sites that represent warm-water (W) fisheries, none had median summer daily mean temperatures that exceeded the warm-water guideline of $26.7^{\circ} \mathrm{C}$. Summer daily mean water temperatures at Teton River at Loma, Musselshell River at Mosby, and Milk River at Nashua exceeded the warmwater guideline, but only for a few days. Summer daily mean water temperatures at Missouri River near Culbertson did not exceed the warm-water guideline. A notable observation is the similarity of median temperatures in the mainstem Missouri River at Toston and near Culbertson, despite the inflows of intervening tributaries with warmer water. The relatively low temperatures at Missouri River near Culbertson are presumably the result of cold water discharged from Fort Peck Reservoir about 150 river mi upstream. 


\section{SUMMER DAILY MEAN WATER TEMPERATURE}
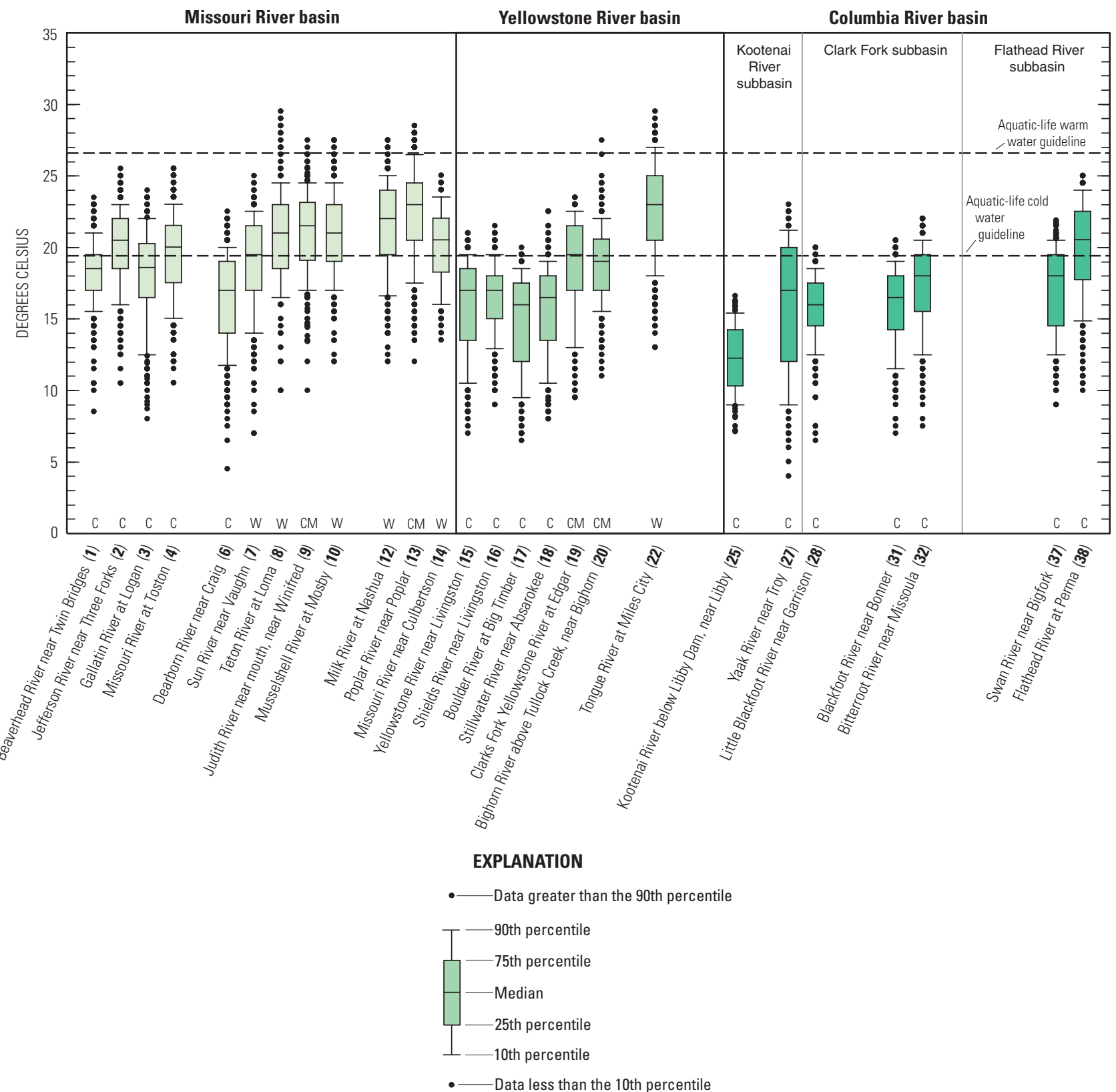

Note: When a data set contains multiple equal values, two or more of the percentile lines can overlap and result in a compressed plot

Figure 5. Statistical distribution of summer (June-August) daily mean water temperatures at selected network sites with continuous temperature recorders in Montana, water years 1999-2003. Site number presented after station name (fig. 1, table 1). Letters at base of the graph represent abbreviations for the type of aquatic biota supported by the streams (Montana Department of Environmental Quality, 2002a) based on water-use classifications: C, cold water (class A-1 and B-1); CM, cold water, marginal (class B-2); and W, warm water (class B-3 and C-3). The State of Montana water-temperature guidelines (Montana Department of Environmental Quality, 2002b) of 19.4 degrees Celsius (67.0 degrees Fahrenheit) and 26.7 degrees Celsius (80.0 degrees Fahrenheit) represent the maximum temperature recommended for salmonid (C and $\mathrm{CM}$ ) and nonsalmonid (W) fisheries, respectively. 
In the Yellowstone River basin, summer daily mean water temperatures at sites with continuous temperature recorders ranged from $6.5^{\circ} \mathrm{C}$ at Boulder River at Big Timber to $29.5^{\circ} \mathrm{C}$ at Tongue River at Miles City. Median summer daily mean water temperatures ranged from $16.0^{\circ} \mathrm{C}$ at Boulder River at Big Timber to $23.0^{\circ} \mathrm{C}$ at Tongue River at Miles City (fig. 5). Water temperatures were distinctly higher in three tributaries (Clarks Fork Yellowstone, Bighorn, and Tongue Rivers). The four most upstream sites (Yellowstone River near Livingston, Shields River near Livingston, Boulder River at Big Timber, and Stillwater River near Absarokee), which represent cold-water $(\mathrm{C})$ fisheries, exceeded the cold-water guideline of $19.4{ }^{\circ} \mathrm{C}$ on 10 percent or fewer days. Summer daily mean water temperatures at Clarks Fork Yellowstone River at Edgar and Bighorn River near Bighorn, which represent cold-water marginal (CM) fisheries, exceeded the cold-water guideline on about 50 percent of the days. Summer daily mean water temperatures at Tongue River at Miles City, which represents warm-water (W) fisheries, exceeded the warm-water guideline on about 10 percent of the days.

In the Columbia River basin, only about one-half of the sites were equipped with continuous water-temperature recorders. Summer daily mean water temperatures ranged from $4.0{ }^{\circ} \mathrm{C}$ at Yaak River near Troy to $25.0^{\circ} \mathrm{C}$ at Flathead River at Perma. Median summer daily mean temperatures ranged from $12.5^{\circ} \mathrm{C}$ at Kootenai River below Libby Dam to $20.5^{\circ} \mathrm{C}$ at Flathead River at Perma. All of the sites in the Columbia River basin represent cold-water (C) fisheries. Flathead River at Perma was the only site in the Columbia River basin having a median summer daily mean water temperature that exceeded the cold water guideline of $19.4{ }^{\circ} \mathrm{C}$, although every other site, except Kootenai River below Libby Dam, had occasional to moderately frequent exceedances of the cold-water guideline. Summer daily mean water temperatures at Yaak River near Troy, Bitterroot River near Missoula, and Swan River near Bigfork exceeded the cold-water guideline on about 25 percent of the days during the summer months of 1999-2003.

\section{Nutrients}

Nutrients were a primary constituent group analyzed in every sample collected for the statewide monitoring program. Although nutrients are essential to plant growth, elevated concentrations of nitrogen or phosphorus can be detrimental to the health of an aquatic system by promoting excessive plant growth. Nutrient enrichment in streams can lead to eutrophication, which is a condition characterized by increased biological productivity and associated decomposition of organic material that can lead to nuisance levels of algae, accumulation of organic material on streambeds, or depletion of dissolved oxygen. In addition to effects on aquatic plants, human health can be adversely affected by high concentrations of nitrate by impairing oxygen transport in the circulatory system of infants (U.S. Environmental Protection Agency, 1986). In general, concentrations of nutrients in unfiltered samples (total ammonia plus organic nitrogen and total phosphorus) tend to increase during conditions of runoff and high suspended-sediment concentrations as the result of adsorption of these compounds to sediment particles. Concentrations of nutrients in filtered samples (dissolved nitrite plus nitrate, dissolved nitrite, and dissolved orthophosphate) have a more variable response to differing hydrologic conditions, possibly responding to instream biological processes or seasonal land-use practices.

Nutrients sampled for this program were compounds of nitrogen $(\mathrm{N})$ or phosphorus $(\mathrm{P})$ that are essential for the growth of aquatic plants. The nutrient compounds analyzed included dissolved nitrite plus nitrate, dissolved nitrite, total ammonia plus organic nitrogen, dissolved orthophosphate, and total phosphorus (table 2). To provide an approximate measure of total nitrogen concentrations, the concentrations of dissolved nitrite plus nitrate and total ammonia plus organic nitrogen were summed. The statistical distributions of nutrient concentrations at network sites during water years 1999-2003 are summarized in table 15.

\section{Dissolved Nitrite plus Nitrate}

The statistical distribution of dissolved nitrite plus nitrate concentrations as $\mathrm{N}$ at network sites during water years 1999-2003 is shown in figure 6. Concentrations of nitrate as $\mathrm{N}$ exceeding $10 \mathrm{mg} / \mathrm{L}$ may cause methemoglobinemia in small children (U.S. Environmental Protection Agency, 1986). This value has been adopted as a State of Montana humanhealth standard for drinking water (Montana Department of Environmental Quality, 2004). Because nitrate tends to be the predominant form of inorganic nitrogen in surface waters (Allen and Kramer, 1972), a general eutrophication guideline of $0.30 \mathrm{mg} / \mathrm{L}$ also is used as a reference concentration for inorganic nitrogen that could potentially stimulate algal growth in the presence of adequate phosphorus (Mackenthun, 1969).

Across the network, concentrations of dissolved nitrite plus nitrate ranged from $<0.005$ to $3.80 \mathrm{mg} / \mathrm{L}$ as N. Consistent spatial patterns were not evident, although the lowest concentrations of dissolved nitrite plus nitrate in the statewide network generally were measured in the Columbia River basin. Dissolved nitrite concentrations consistently were low (less than $0.01 \mathrm{mg} / \mathrm{L}$ ) or less than the LRL; therefore, boxplots are not presented for dissolved nitrite. Because dissolved nitrite concentrations were low, the combined nitrite plus nitrate concentrations were used as a reference for comparison to the human-health standard for nitrate and the general eutrophication guideline. None of the sites in the statewide network had samples with dissolved nitrite plus nitrate concentrations that exceeded the human-health standard of $10 \mathrm{mg} / \mathrm{L}$ for nitrate as $\mathrm{N}$.

In the Missouri River basin, concentrations of dissolved nitrite plus nitrate ranged from $<0.005 \mathrm{mg} / \mathrm{L}$ at several sites to $3.80 \mathrm{mg} / \mathrm{L}$ at Sun River near Vaughn and were mostly less than $1 \mathrm{mg} / \mathrm{L}$. Many analyses were less than the LRL. Median concentrations of dissolved nitrite plus nitrate in the Missouri River basin ranged from $<0.013 \mathrm{mg} / \mathrm{L}$ as $\mathrm{N}$ at Poplar River 


\section{DISSOLVED NITRITE PLUS NITRATE}
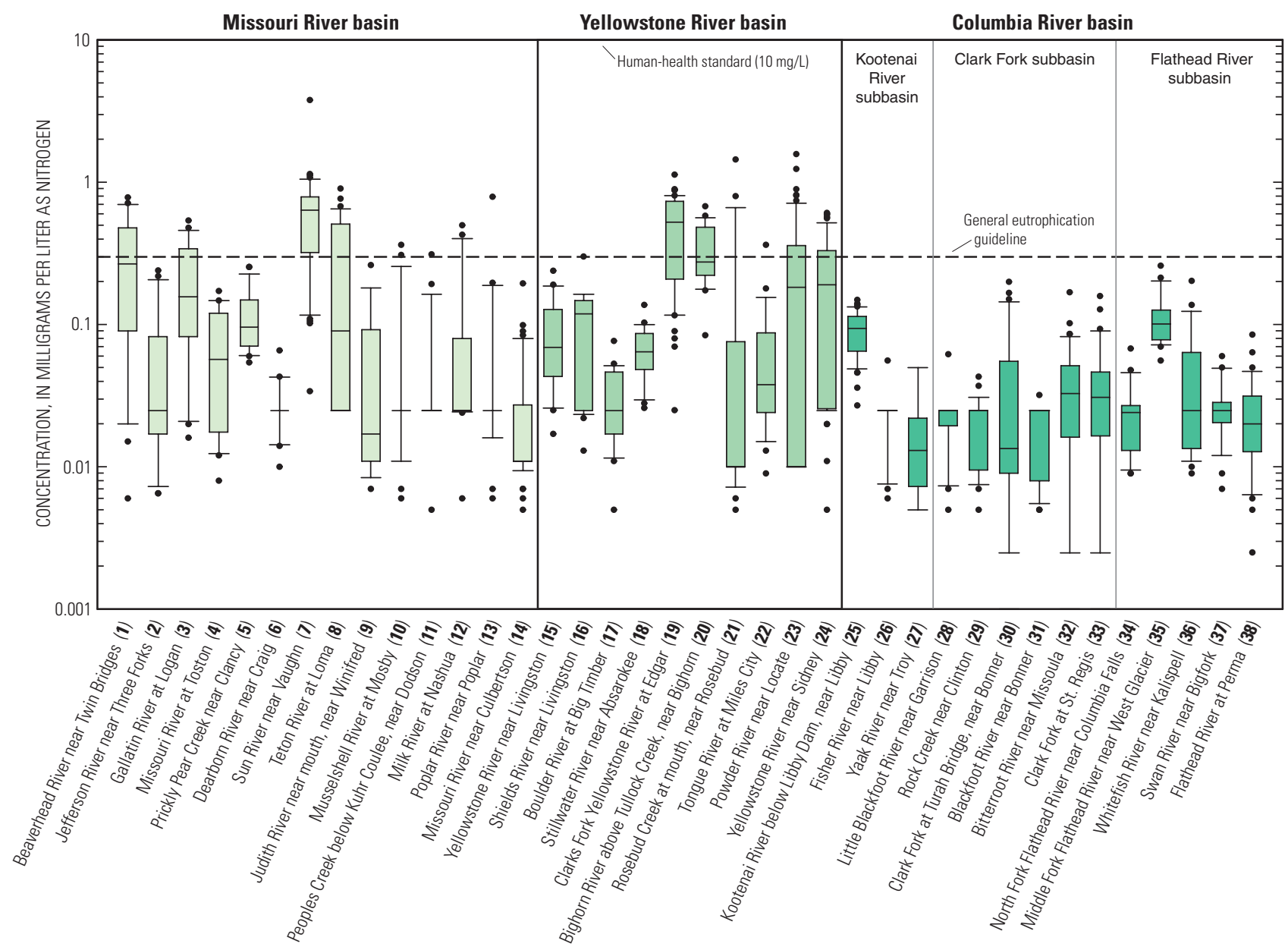

\section{EXPLANATION}

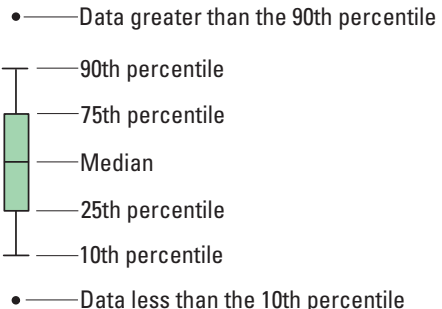

Note: When a data set contains multiple equal values, two or more of the percentile lines can overlap and result in a compressed plot

Figure 6. Statistical distribution of concentrations of dissolved nitrite plus nitrate at network sites in Montana, water years 1999-2003. Site number presented after station name (fig. 1, table 1). The U.S. Department of the Interior general eutrophication guideline is 0.30 milligram per liter (Mackenthun, 1969). Concentrations reported as less than the laboratory reporting level are plotted as one-half the maximum laboratory reporting level. 
near Poplar to $0.610 \mathrm{mg} / \mathrm{L}$ as $\mathrm{N}$ at Sun River near Vaughn (fig. 6, table 15). The median concentration $(0.610 \mathrm{mg} / \mathrm{L}$ as $\mathrm{N})$ at Sun River near Vaughn was more than two times greater than the next highest median concentration in the basin.

About one-half of the sites had one or more samples with dissolved nitrite plus nitrate concentrations exceeding the general eutrophication guideline of $0.30 \mathrm{mg} / \mathrm{L}$ (fig. 6). The guideline was most frequently exceeded (about 75 percent of the samples) at Sun River near Vaughn; the guideline also was exceeded (more than 25 percent of the samples) at Beaverhead River near Twin Bridges, Gallatin River at Logan, and Teton River at Loma.

In the Yellowstone River basin, dissolved nitrite plus nitrate concentrations ranged from $<0.005 \mathrm{mg} / \mathrm{L}$ at Rosebud Creek near Rosebud and Yellowstone River near Sidney to $1.58 \mathrm{mg} / \mathrm{L}$ at Powder River near Locate and also were mostly less than $1 \mathrm{mg} / \mathrm{L}$. Many analyses were less than the LRL. Median concentrations of dissolved nitrite plus nitrate ranged from $0.024 \mathrm{mg} / \mathrm{L}$ as $\mathrm{N}$ at Boulder River at Big Timber to $0.525 \mathrm{mg} / \mathrm{L}$ as $\mathrm{N}$ at Clarks Fork Yellowstone River at Edgar. The median dissolved nitrite plus nitrate concentration $(0.525 \mathrm{mg} / \mathrm{L})$ at Clarks Fork Yellowstone River at Edgar was substantially higher than the other sites in the Yellowstone River basin.

About one-half the sites in the Yellowstone River basin had one or more samples with dissolved nitrite plus nitrate concentrations exceeding the general eutrophication guideline. The guideline was most frequently exceeded (more than 50 percent of the samples) at Clarks Fork Yellowstone River near Edgar. The general eutrophication guideline was exceeded in about 25 to 50 percent of the samples at Bighorn River near Bighorn, Powder River near Locate, and Yellowstone River near Sidney.

In the Columbia River basin, concentrations of dissolved nitrite plus nitrate ranged from $<0.005 \mathrm{mg} / \mathrm{L}$ at several sites to $0.260 \mathrm{mg} / \mathrm{L}$ at Middle Fork Flathead River at West Glacier and commonly were less than $0.05 \mathrm{mg} / \mathrm{L}$. Many analyses were less than the LRL. Median concentrations of dissolved nitrite plus nitrate ranged from $<0.022 \mathrm{mg} / \mathrm{L}$ as $\mathrm{N}$ at Fisher Creek near Libby and Yaak River near Troy to $0.102 \mathrm{mg} / \mathrm{L}$ as $\mathrm{N}$ at Middle Fork Flathead River near West Glacier (fig. 6, table 15). Maximum concentrations at all sites in the basin were less than $0.30 \mathrm{mg} / \mathrm{L}$. The general eutrophication guideline was not exceeded at any of the sites in the Columbia River basin.

\section{Total Ammonia Plus Organic Nitrogen}

The statistical distribution of total ammonia plus organic nitrogen (commonly referred to as total kjeldahl nitrogen, or TKN) concentrations at network sites during water years 1999-2003 is shown in figure 7. Across the network, concentrations of total ammonia plus organic nitrogen ranged from $<0.08$ to $30 \mathrm{mg} / \mathrm{L}$ as $\mathrm{N}$ (table 15 ). Concentrations of total ammonia plus organic nitrogen commonly increased during conditions of high streamflow and suspended-sediment concentrations. Similar to dissolved nitrite plus nitrate, the total ammonia plus organic nitrogen values measured at sites in the Columbia River basin generally were lower than at most sites in the Missouri or Yellowstone River basins. Median concentrations varied among sites to a greater degree in the Missouri and Yellowstone River basins compared to the Columbia River basin, but no clear spatial pattern was evident. The highest concentrations in the Missouri and Yellowstone River basins were measured in tributaries in the lower parts of the basins.

In the Missouri River basin, concentrations of total ammonia plus organic nitrogen ranged from $<0.08 \mathrm{mg} / \mathrm{L}$ at Dearborn River near Craig to $5.2 \mathrm{mg} / \mathrm{L}$ at Teton River near Loma and most analyses were greater than the LRL. Median concentrations of total ammonia plus organic nitrogen ranged from $0.10 \mathrm{mg} / \mathrm{L}$ as $\mathrm{N}$ at Dearborn River near Craig to $0.88 \mathrm{mg} / \mathrm{L}$ as $\mathrm{N}$ at Milk River at Nashua (fig. 7, table 15). Four tributary sites (Musselshell River at Mosby, Peoples Creek near Dodson, Milk River at Nashua, and Poplar River near Poplar) in the lower part of the Missouri River basin had elevated median concentrations compared to the rest of the sites in the basin. The two mainstem sites (Missouri River at Toston and Missouri River near Culbertson) had very similar distributions of total ammonia plus organic nitrogen concentrations, with nearly identical values for the median concentration.

In the Yellowstone River basin, total ammonia plus organic nitrogen concentrations ranged from E0.04 mg/L at Yellowstone River near Sidney to $30 \mathrm{mg} / \mathrm{L}$ at Powder River near Locate and generally were similar to those at sites in the Missouri River basin (fig. 7). The maximum concentration $(30 \mathrm{mg} / \mathrm{L}$ as $\mathrm{N}$ ) measured in a sample collected at Powder River near Locate also was the highest concentration of total ammonia plus organic nitrogen measured in the statewide network. The second highest maximum concentration $(17 \mathrm{mg} / \mathrm{L}$ as N) was measured at Rosebud Creek near Rosebud (fig. 7).

Median concentrations for total ammonia plus organic nitrogen ranged from $0.16 \mathrm{mg} / \mathrm{L}$ as $\mathrm{N}$ at Boulder River at Big Timber to $0.74 \mathrm{mg} / \mathrm{L}$ as $\mathrm{N}$ at Rosebud Creek near Rosebud (table 15). Two sites (Boulder River at Big Timber and Stillwater River near Absarokee) had notably lower median concentrations of total ammonia plus organic nitrogen compared to the other sites in the Yellowstone River basin. Both streams drain headwater areas of mountainous terrain and forest with relatively little urban development. At the mainstem sites, the median concentration of total ammonia plus organic nitrogen at Yellowstone River near Sidney was about double that of the median concentration at Yellowstone River near Livingston, and the maximum concentration was nearly three times higher.

In the Columbia River basin, total ammonia plus organic nitrogen concentrations ranged from $<0.08 \mathrm{mg} / \mathrm{L}$ at North Fork Flathead River near Columbia Falls and Middle Fork Flathead River near West Glacier to $1.7 \mathrm{mg} / \mathrm{L}$ at Flathead River at Perma and generally were lower than at most sites in the Missouri or Yellowstone River basins (fig. 7). Median concentrations ranged from $0.07 \mathrm{mg} / \mathrm{L}$ as $\mathrm{N}$ at Middle Fork Flathead River near West Glacier to $0.28 \mathrm{mg} / \mathrm{L}$ as $\mathrm{N}$ at Little Blackfoot River near Garrison (table 15). The highest concentration $(1.7 \mathrm{mg} / \mathrm{L}$ as $\mathrm{N})$ measured in a sample collected at 
TOTAL AMMONIA PLUS ORGANIC NITROGEN

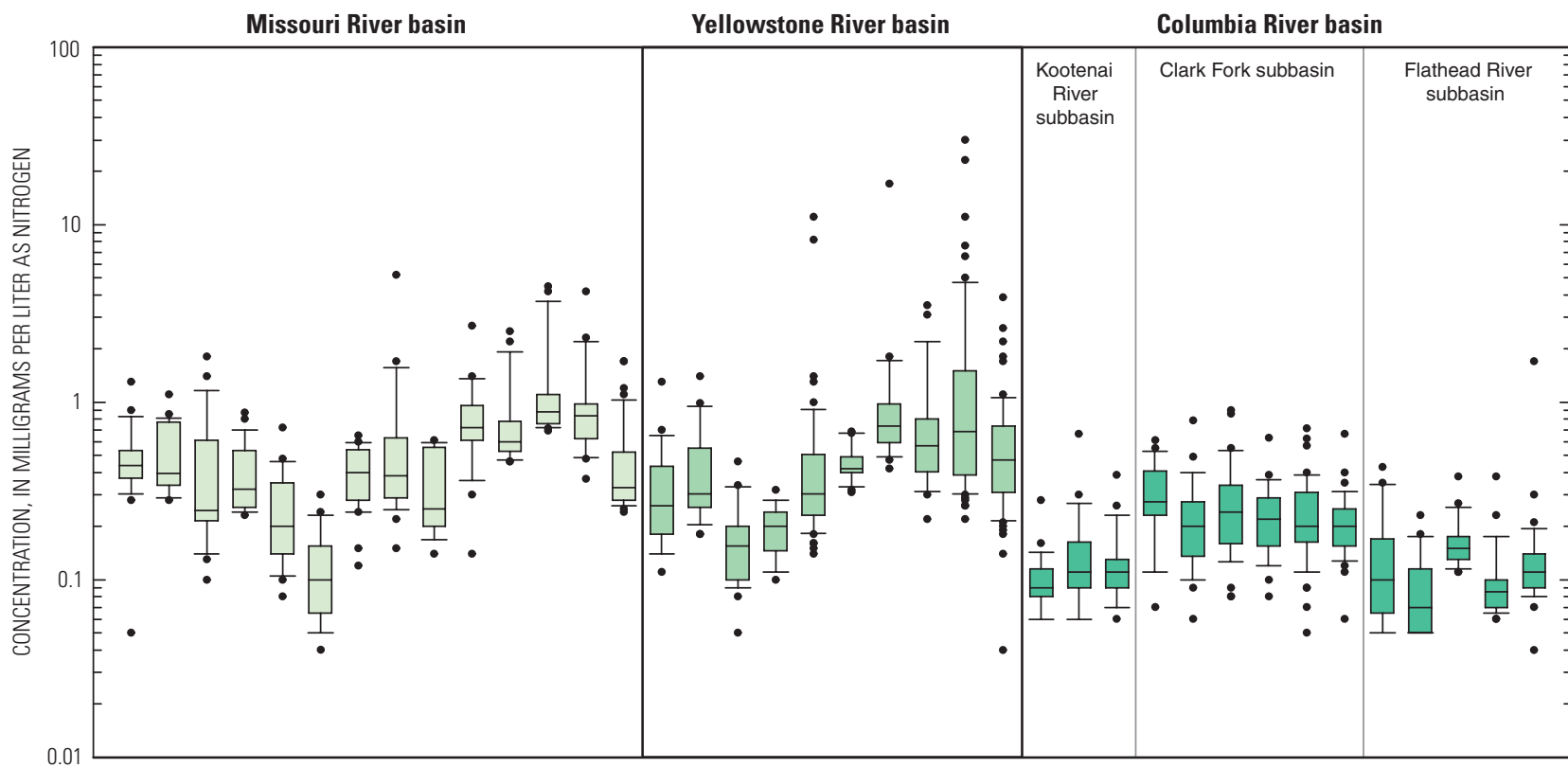

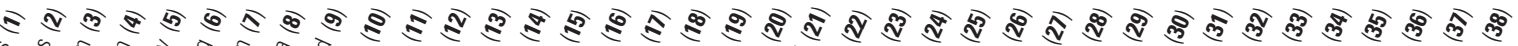

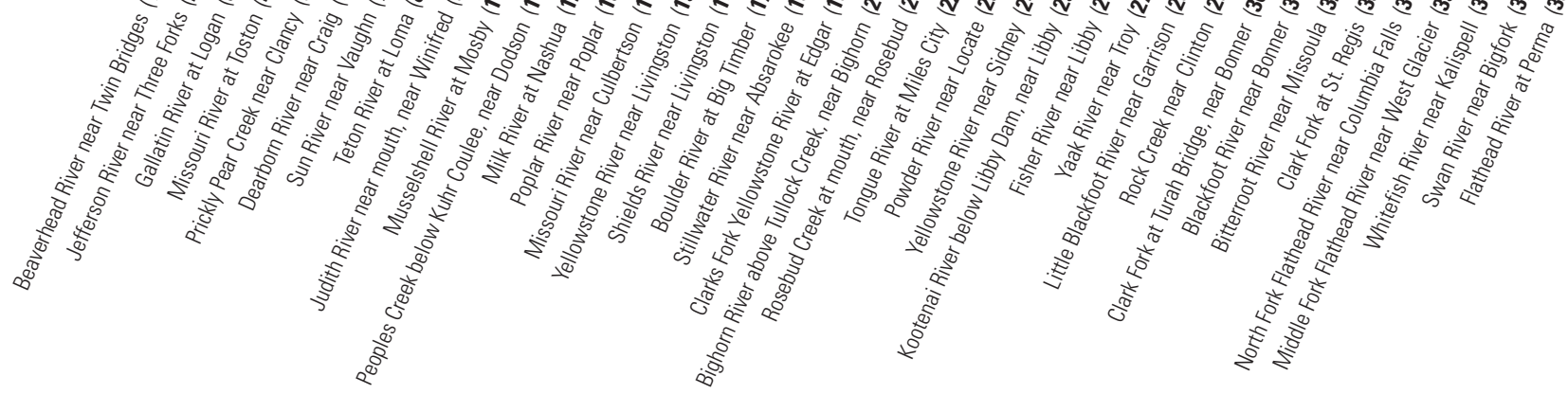

EXPLANATION

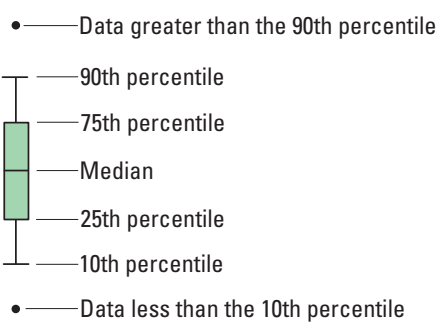

Note: When a data set contains multiple equal values, two or more of

the percentile lines can overlap and result in a compressed plot

Figure 7. Statistical distribution of concentrations of total ammonia plus organic nitrogen at network sites in Montana, water years 1999-2003. Site number presented after station name (fig. 1, table 1). Concentrations reported as less than the laboratory reporting level are plotted as one-half the maximum laboratory reporting level. 
Flathead River at Perma was almost two times greater than the next highest concentration $(0.90 \mathrm{mg} / \mathrm{L}$ as $\mathrm{N})$ measured at Clark Fork at Turah Bridge.

The six sites in the Clark Fork subbasin (sites 28-32, fig. 7) had distinctly higher median concentrations of total ammonia plus organic nitrogen compared to sites in the Kootenai and Flathead River subbasins. The generally consistent medians and ranges of concentrations among the six sites might indicate that the predominant sources of total ammonia plus organic nitrogen in this part of the basin are similar and widespread.

\section{Total Nitrogen}

Concentrations of total nitrogen were not analyzed directly because the analytical method was not available during the 1999-2003 monitoring period. However, total nitrogen concentrations were estimated by adding concentrations of dissolved nitrite plus nitrate and total ammonia plus organic nitrogen. These estimated concentrations are intended only for general comparisons among sites or to water-quality standards or guidelines. The Montana Department of Environmental Quality (2002b) has established a stream-specific numeric standard of $0.300 \mathrm{mg} / \mathrm{L}$ for total nitrogen as $\mathrm{N}$ for the mainstem reach of the Clark Fork that encompasses Clark Fork at Turah Bridge and Clark Fork at St. Regis. This standard is applicable seasonally during June 21-September 21. In addition to this seasonal standard for the Clark Fork, the U.S. Environmental Protection Agency (2001a,b) provides an ecoregion guideline concentration of $1.50 \mathrm{mg} / \mathrm{L}$ for total nitrogen to prevent eutrophication within applicable areas of central and eastern Montana.

The statistical distribution of estimated concentrations of total nitrogen at network sites during water years 1999-2003 is shown in figure 8 . Across the network, estimated concentrations of total nitrogen ranged from 0.043 to $31.6 \mathrm{mg} / \mathrm{L}$ (table 15). The magnitudes and spatial patterns of total nitrogen concentrations were very similar to those of total ammonia plus organic nitrogen. Estimated total nitrogen concentrations at sites in the Columbia River basin generally were lower than at most of the sites in the Missouri or Yellowstone River basins.

In the Missouri River basin, estimated total nitrogen concentrations ranged from $0.043 \mathrm{mg} / \mathrm{L}$ at Dearborn River near Craig to $5.80 \mathrm{mg} / \mathrm{L}$ at Teton River at Loma. Median estimated concentrations of total nitrogen ranged from $0.119 \mathrm{mg} / \mathrm{L}$ at Dearborn River near Craig to the very similar medians of 0.922 and $0.937 \mathrm{mg} / \mathrm{L}$ at Sun River near Vaughn and Milk River at Nashua (fig. 8, table 15), respectively. Two other streams in the lower Missouri River basin (Musselshell River at Mosby and Poplar River near Poplar) also had median concentrations of total nitrogen $(0.727$ and $0.851 \mathrm{mg} / \mathrm{L}$, respectively) that were somewhat elevated compared to other sites in the basin. The two mainstem sites (Missouri River at Toston and near Culbertson) had similar median concentrations of total nitrogen of 0.388 and $0.333 \mathrm{mg} / \mathrm{L}$, respectively. The negligible difference in median total-nitrogen concentrations between the two mainstem sites, even though most tributaries contribute water having higher concentrations, may result from nutrient uptake or deposition within the mainstem reservoirs between the two sites.

The only site in the Missouri River basin where most of the estimated total nitrogen concentrations were substantially higher than that of total ammonia plus organic nitrogen was Sun River near Vaughn, which indicates that dissolved nitrite plus nitrate composed a relatively large percentage of the total nitrogen at this site. With the exception of Judith River near Winifred, concentrations in one or more samples from all of the sites in the lower basin (Teton River and downstream) exceeded the ecoregion eutrophication guideline of $1.50 \mathrm{mg} / \mathrm{L}$.

In the Yellowstone River basin, estimated total nitrogen concentrations ranged from $0.098 \mathrm{mg} / \mathrm{L}$ at Boulder River near Big Timber to $31.6 \mathrm{mg} / \mathrm{L}$ at Powder River near Locate. The highest concentration measured at Powder River near Locate also was the highest in the statewide network. Median estimated concentrations of total nitrogen ranged from $0.173 \mathrm{mg} / \mathrm{L}$ at Boulder River at Big Timber to very similar medians ranging from 0.84 to $0.885 \mathrm{mg} / \mathrm{L}$ at three sites (Clarks Fork Yellowstone River at Edgar, Bighorn River near Bighorn, and Powder River near Locate). Three other sites with somewhat elevated median concentrations were Rosebud Creek near Rosebud (0.744 mg/L), Yellowstone River near Sidney (0.690 mg/L), and Tongue River near Miles City $(0.578 \mathrm{mg} / \mathrm{L})$.

Unlike the Missouri River basin, the lower mainstem site at Yellowstone River near Sidney had a median total nitrogen concentration $(0.690 \mathrm{mg} / \mathrm{L})$ that was about twice as high as the upper mainstem site at Yellowstone River near Livingston (0.383 mg/L). The Yellowstone River does not have mainstem reservoirs; thus, concentrations of total nitrogen in the mainstem may more closely reflect simple mixing of tributary inflows and be less affected by biological productivity and nutrient cycling that can occur in lakes and reservoirs. The only site in the Yellowstone River basin where most of the total nitrogen concentrations were substantially higher than that of total ammonia plus organic nitrogen was Clarks Fork Yellowstone River at Edgar, which indicates that dissolved nitrite plus nitrate composed a relatively large percentage of the total nitrogen in samples from this site (figs. 7 and 8). Concentrations in samples from all of the sites in the lower part of the basin (Clarks Fork Yellowstone River at Edgar and downstream) exceeded the ecoregion eutrophication guideline of $1.50 \mathrm{mg} / \mathrm{L}$, although only infrequently at five of the six sites (fig. 8). Concentrations at Powder River near Locate exceeded the ecoregion guideline in more than 25 percent of the samples.

In the Columbia River basin, total nitrogen concentrations ranged from $0.050 \mathrm{mg} / \mathrm{L}$ at North Fork Flathead River near Columbia Falls to $1.72 \mathrm{mg} / \mathrm{L}$ at Flathead River near Perma (fig. 8, table 15). Median estimated concentrations of total nitrogen ranged from $0.098 \mathrm{mg} / \mathrm{L}$ at Swan River near Bigfork to $0.293 \mathrm{mg} / \mathrm{L}$ at Little Blackfoot River near Garrison. 
ESTIMATED TOTAL NITROGEN

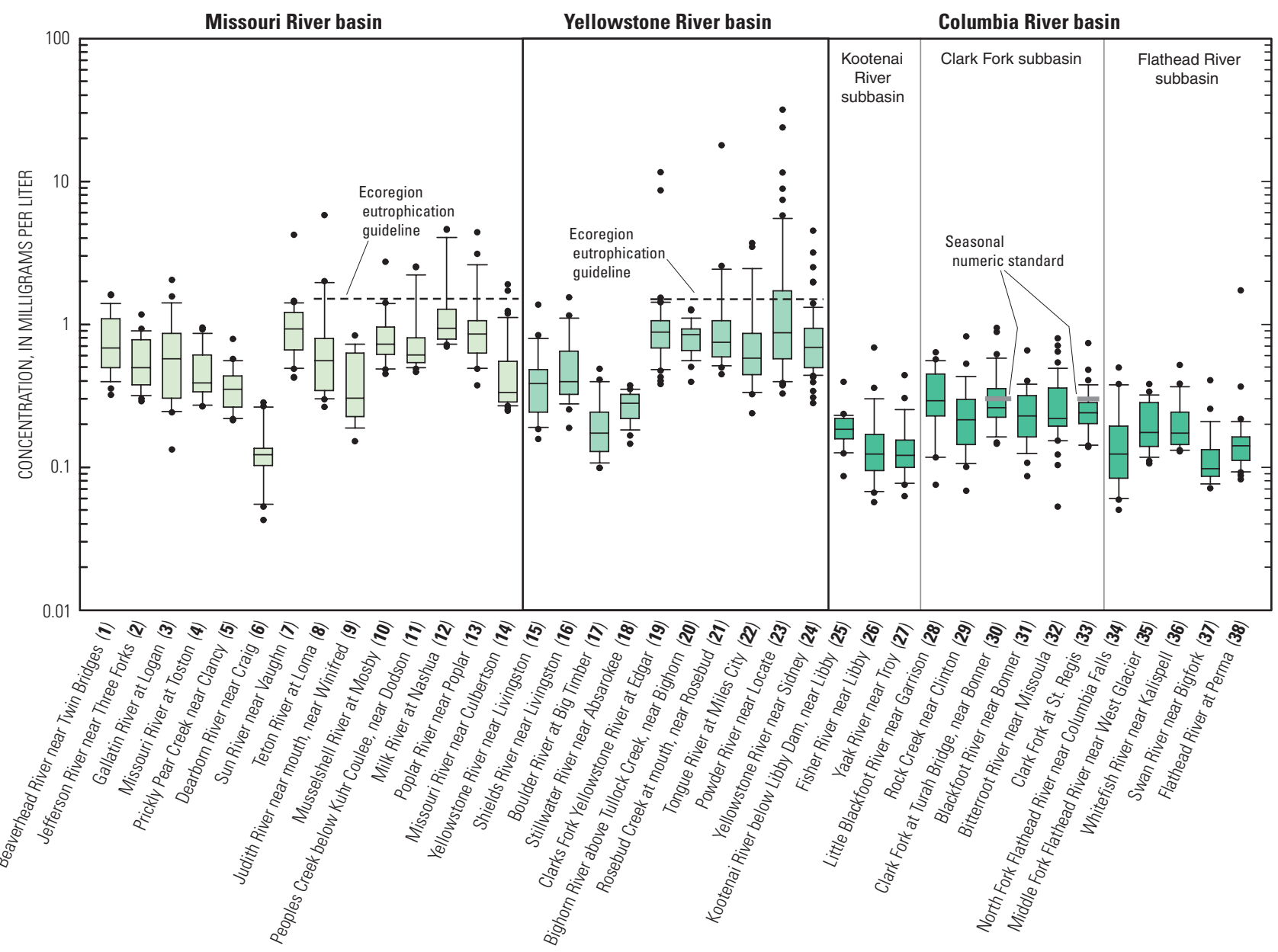

EXPLANATION

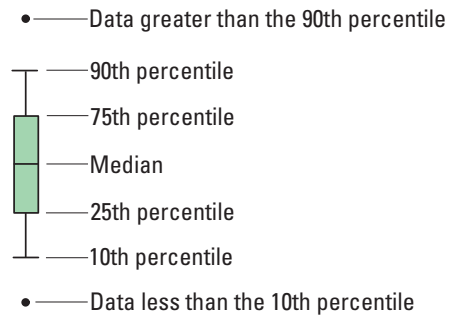

Note: When a data set contains multiple equal values, two or more of the percentile lines can overlap and result in a compressed plot

Figure 8. Statistical distribution of estimated concentrations of total nitrogen at network sites in Montana, water years 1999-2003. Site number presented after station name (fig. 1, table 1). Total nitrogen concentrations were determined by adding concentrations of dissolved nitrite plus nitrate and total ammonia plus organic nitrogen. Concentrations reported as less than the laboratory reporting level are plotted as one-half the maximum laboratory reporting level. The State of Montana seasonal (June 21-September 21) numeric standard (Montana Department of Environmental Quality, 2002b) of 0.300 milligram per liter is designated for the mainstem of the Clark Fork. The ecoregion eutrophication guideline provided by the U.S. Environmental Protection Agency $(2001 \mathrm{a}, \mathrm{b})$ is 1.50 milligrams per liter for areas in central and eastern Montana. 
Similar to the pattern observed for total ammonia plus organic nitrogen, the median concentrations of estimated total nitrogen for all six sites in the Clark Fork subbasin were higher when compared to sites in the Kootenai and Flathead River subbasins.

Two sites in the Columbia River basin (Kootenai River below Libby Dam and Middle Fork Flathead River near West Glacier) had statistical distributions of estimated total nitrogen concentrations (fig. 8) that were notably higher than that of total ammonia plus organic nitrogen (fig. 7), thereby indicating that dissolved nitrite plus nitrate composed a relatively large percentage of the total nitrogen in samples from these two sites. For the two sites (Clark Fork at Turah Bridge and Clark Fork at St. Regis) with a stream-specific numeric standard for total nitrogen of $0.300 \mathrm{mg} / \mathrm{L}$, the standard was exceeded in about 25 percent or more of the samples.

\section{Dissolved Orthophosphate}

The statistical distribution of dissolved orthophosphate concentrations at network sites during water years 1999-2003 is shown on figure 9. Across the network, dissolved orthophosphate concentrations ranged from $<0.001$ to $0.158 \mathrm{mg} / \mathrm{L}$ as $\mathrm{P}$ (table 15). Concentrations at most sites were consistently less than $0.04 \mathrm{mg} / \mathrm{L}$, with about 50 percent of the samples having concentrations less than the LRL. Generally, concentrations were more variable in the Missouri River basin than in the Yellowstone or Columbia River basins. Standards are not currently (2006) established for dissolved orthophosphate concentrations.

In the Missouri River basin, dissolved orthophosphate concentrations ranged from $<0.001 \mathrm{mg} / \mathrm{L}$ at many sites to $0.158 \mathrm{mg} / \mathrm{L}$ at Peoples Creek near Dodson (table 15). Median concentrations of dissolved orthophosphate ranged from $<0.007 \mathrm{mg} / \mathrm{L}$ as $\mathrm{P}$ at several sites to $0.017 \mathrm{mg} / \mathrm{L}$ as $\mathrm{P}$ at Milk River at Nashua (fig. 9, table 15). Peoples Creek near Dodson had the largest variation in orthophosphate concentrations of any site in the network, with more than 10 percent of the samples having concentrations greater than $0.10 \mathrm{mg} / \mathrm{L}$. Other relatively large variations occurred at Milk River at Nashua and Poplar River near Poplar (fig. 9).

In the Yellowstone River basin, dissolved orthophosphate concentrations ranged from $<0.001 \mathrm{mg} / \mathrm{L}$ at many sites to $0.040 \mathrm{mg} / \mathrm{L}$ at Clarks Fork Yellowstone River at Edgar (table 15). Yellowstone River near Livingston was the only site where all the samples had dissolved orthophosphate concentrations greater than the LRL. No clear spatial pattern was evident among the sites (fig. 9). Median concentrations of dissolved orthophosphate ranged from $<0.007 \mathrm{mg} / \mathrm{L}$ as $\mathrm{P}$ at several sites to $0.016 \mathrm{mg} / \mathrm{L}$ as $\mathrm{P}$ at Yellowstone River near Livingston.

In the Columbia River basin, dissolved orthophosphate concentrations ranged from $<0.001 \mathrm{mg} / \mathrm{L}$ at many sites to $0.049 \mathrm{mg} / \mathrm{L}$ at Rock Creek near Clinton (table 15). Little Blackfoot River near Garrison was the only site in the Columbia River basin where all samples had dissolved orthophos- phate concentrations greater than the LRL. Median concentrations of dissolved orthophosphate ranged from $<0.007 \mathrm{mg} / \mathrm{L}$ as $\mathrm{P}$ at all sites outside the Clark Fork subbasin to $0.019 \mathrm{mg} / \mathrm{L}$ as $\mathrm{P}$ at Little Blackfoot River near Garrison. The median concentration of dissolved orthophosphate at Little Blackfoot River was more than double the median concentration at the other sites in the Columbia River basin. Although the maximum concentration of dissolved orthophosphate $(0.049 \mathrm{mg} / \mathrm{L}$ as P) was measured in Rock Creek near Clinton, the median orthophosphate concentration ( $0.006 \mathrm{mg} / \mathrm{L}$ as $\mathrm{P})$ in Rock Creek was substantially lower compared to the Little Blackfoot River.

\section{Total Phosphorus}

The statistical distribution of total phosphorus concentrations at network sites during water years 1999-2003 is shown in figure 10. Across the network, concentrations of total phosphorus ranged from $<0.01$ to $15.4 \mathrm{mg} / \mathrm{L}$. Concentrations of total phosphorus commonly increased during periods of runoff and high suspended-sediment concentrations (table 15).

State of Montana seasonal numeric standards of 0.020 and $0.039 \mathrm{mg} / \mathrm{L}$ established by the Montana Department of Environmental Quality (2002b) for the reach of the Clark Fork mainstem that encompasses Clark Fork at Turah Bridge and Clark Fork at St. Regis, respectively, are shown in figure 10. Similar to total nitrogen, these seasonal standards are applicable only during June 21-September 21. Although national criteria have not been established for total phosphorus, the U.S. Environmental Protection Agency (1986) recommends as a general eutrophication guideline that total phosphorus concentrations be maintained below $0.10 \mathrm{mg} / \mathrm{L}$ in flowing waters to prevent eutrophication (fig. 10). A recent ecoregion guideline (U.S. Environmental Protection Agency, 2001a,b) of $0.075 \mathrm{mg} / \mathrm{L}$ for total phosphorus also is shown for the network sites that are located within the applicable areas of central and eastern Montana.

In the Missouri River basin, total phosphorus concentrations ranged from $<0.004 \mathrm{mg} / \mathrm{L}$ at Dearborn River near Craig to $2.12 \mathrm{mg} / \mathrm{L}$ at Teton River at Loma (table 15). Concentrations of total phosphorus typically were greater than the LRL. Milk River at Nashua had a maximum concentration $(1.77 \mathrm{mg} / \mathrm{L})$ nearly as high as the maximum concentration at Teton River at Loma. Many sites had minimum concentrations that were less than $0.01 \mathrm{mg} / \mathrm{L}$, but Dearborn River near Craig consistently had the lowest concentrations of total phosphorus, many of which were less than the LRL (fig. 10).

Median concentrations of total phosphorus ranged from $0.002 \mathrm{mg} / \mathrm{L}$ at Dearborn River near Craig to $0.160 \mathrm{mg} / \mathrm{L}$ at Missouri River near Culbertson (fig. 10, table 15). Total phosphorus concentrations increased downstream along the mainstem, with both the median $(0.160 \mathrm{mg} / \mathrm{L})$ and maximum $(0.760 \mathrm{mg} / \mathrm{L})$ concentrations at Missouri River near Culbertson being about three times greater than the respective concentrations at Missouri River at Toston (fig. 9). This pattern is quite different from that of total nitrogen at these two mainstem sites (fig. 8), where differences in concentration generally 
DISSOLVED ORTHOPHOSPHATE

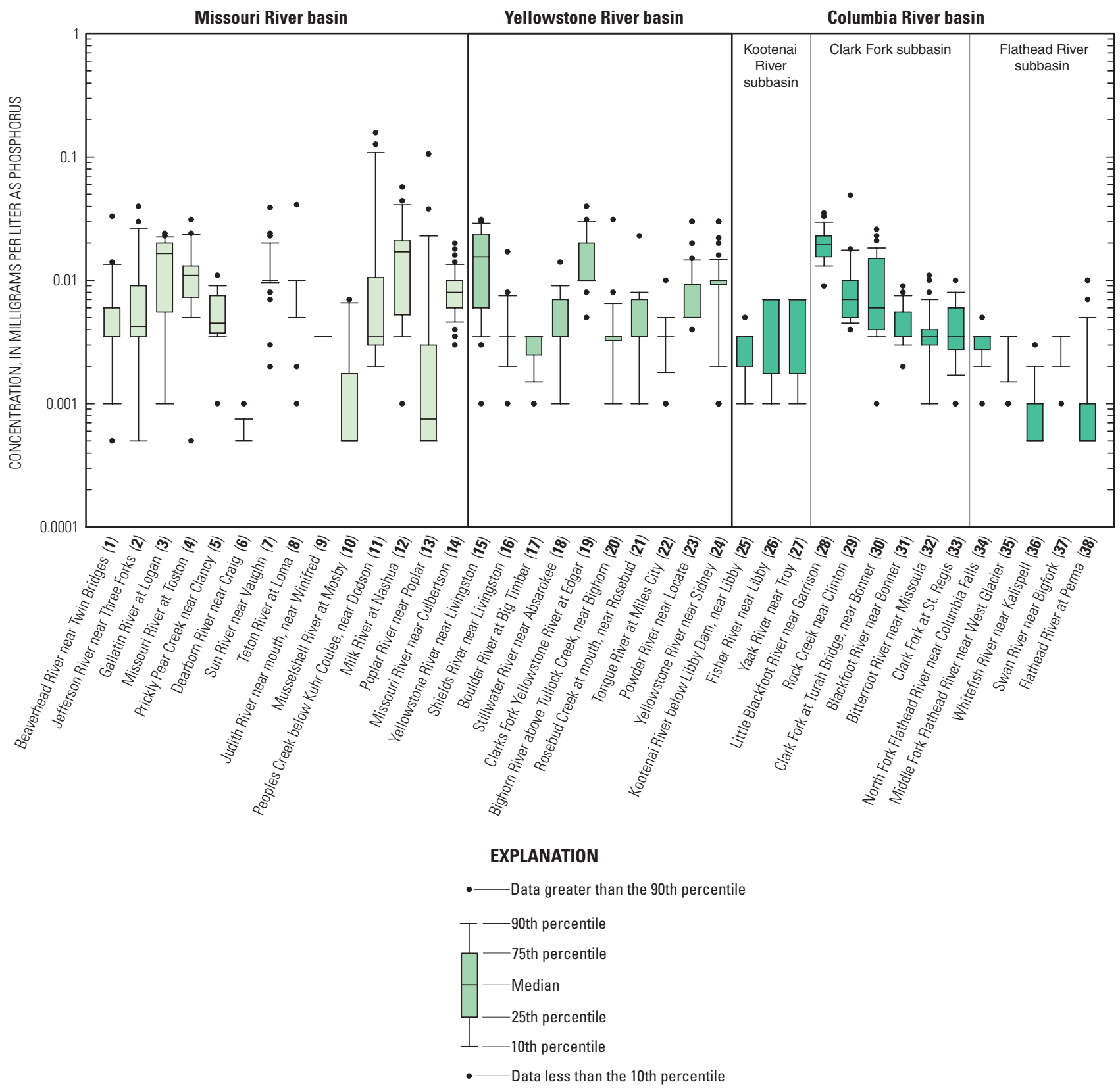

Note: When a data set contains multiple equal values, two or more of the percentile lines can overlap and result in a compressed plot

Figure 9. Statistical distribution of concentrations of dissolved orthophosphate at network sites in Montana, water years 1999-2003. Site number presented after station name (fig. 1, table 1). Concentrations reported as less than the laboratory reporting level are plotted as one-half the maximum laboratory reporting level. 


\section{TOTAL PHOSPHORUS}

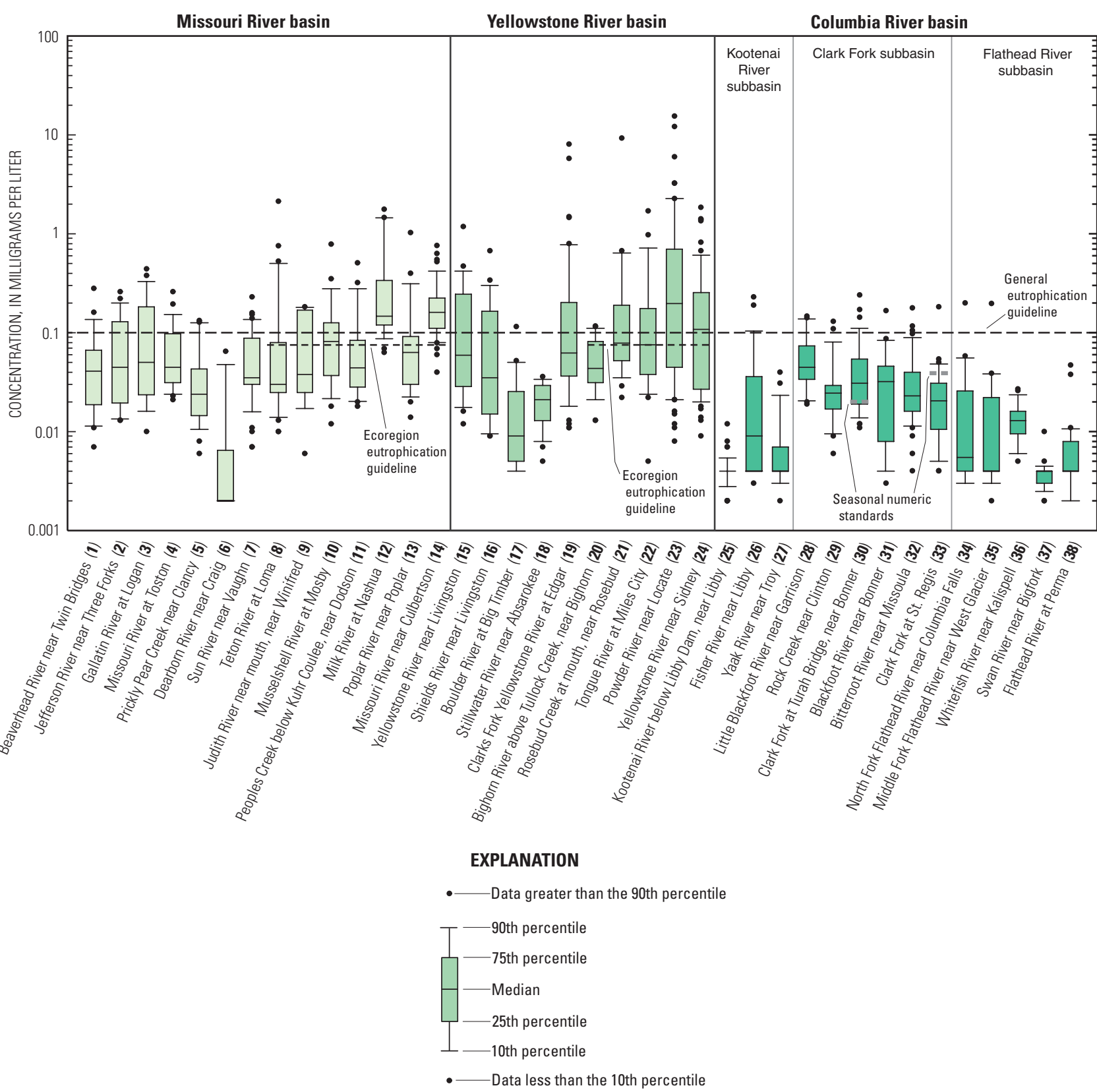

Note: When a data set contains multiple equal values, two or more of the percentile lines can overlap and result in a compressed plot

Figure 10. Statistical distribution of concentrations of total phosphorus at network sites in Montana, water years 1999-2003. Site number presented after station name (fig. 1, table 1). The State of Montana seasonal (June 21-September 21) numeric standards (Montana Department of Environmental Quality, 2002b) of 0.020 and 0.039 milligram per liter are designated for specific mainstem reaches of the Clark Fork. The general eutrophication guideline provided by the U.S. Environmental Protection Agency (1986) is 0.10 milligram per liter. The ecoregion eutrophication guideline provided by the U.S. Environmental Protection Agency $(2001 \mathrm{a}, \mathrm{b})$ is 0.075 milligram per liter for areas in central and eastern Montana. Concentrations reported as less than the laboratory reporting level are plotted as one-half the maximum laboratory reporting level. 
were negligible between the two sites. Milk River at Nashua and Missouri River near Culbertson had concentrations that exceeded both the general and ecoregion eutrophication prevention guidelines in more than 75 percent of the samples. All other sites in the Missouri River basin, except Dearborn River near Craig, had total phosphorus concentrations that exceeded the general guideline in from 10 to more than 25 percent of the samples. A higher frequency of exceedance (about 25 to 50 percent of the samples) of the more restrictive ecoregion guideline occurred in the other tributaries from the Teton River and downstream. Most of the exceedances occurred in the spring and early summer during runoff conditions.

In the Yellowstone River basin, total phosphorus concentrations ranged from $<0.004 \mathrm{mg} / \mathrm{L}$ at Boulder River near Big Timber to $15.4 \mathrm{mg} / \mathrm{L}$ at Powder River near Locate (table 15). Other sites in the Yellowstone River basin having relatively high maximum total phosphorus concentrations were Rosebud Creek near Rosebud (9.24 mg/L) and Clarks Fork Yellowstone River at Edgar (8.06 mg/L). Total phosphorus concentrations varied in a manner similar to the Missouri River basin, although maximum concentrations commonly were higher.

Median concentrations for total phosphorus ranged from $0.009 \mathrm{mg} / \mathrm{L}$ at Boulder River at Big Timber to $0.196 \mathrm{mg} / \mathrm{L}$ at Powder River near Locate (fig. 10, table 15). Similar to values for total nitrogen (fig. 8), median concentrations of total phosphorus were noticeably lower at Boulder River at Boulder and Stillwater River near Absarokee compared to other sites in the basin. The two mainstem sites on the Yellowstone River (Yellowstone River near Livingston and Yellowstone River near Sidney) had a similar range of total phosphorus concentrations; however, the median concentration $(0.098 \mathrm{mg} / \mathrm{L})$ at Yellowstone River near Sidney was about twice as high as the median $(0.059 \mathrm{mg} / \mathrm{L})$ at Yellowstone River near Livingston.

Total phosphorus concentrations at Powder River near Locate and Yellowstone River near Sidney exceeded the general eutrophication guideline in more than 50 percent of the samples. Samples from all other sites in the Yellowstone River basin, except Boulder River at Big Timber and Stillwater River near Absarokee, exceeded the general eutrophication guideline in 10 to more than 25 percent of the samples. The more restrictive ecoregion eutrophication guideline was exceeded more frequently (about 25 to 50 percent of samples) in the Bighorn River, Rosebud Creek, and Tongue River.

In the Columbia River basin, total phosphorus concentrations ranged from $<0.004$ at several sites to $0.240 \mathrm{mg} / \mathrm{L}$ at Clark Fork at Turah Bridge (table 15). Total phosphorus concentrations were relatively low compared to those in the Missouri and Yellowstone River basins. Concentrations of about $0.01 \mathrm{mg} / \mathrm{L}$ or lower were most common at the Kootenai River below Libby Dam, Yaak River near Troy, Swan River near Bigfork, and Flathead River at Perma.

Median concentrations for total phosphorus ranged from $0.002 \mathrm{mg} / \mathrm{L}$ at Kootenai River below Libby Dam and Swan River near Bigfork to $0.045 \mathrm{mg} / \mathrm{L}$ at Little Blackfoot River near Garrison (fig. 10, table 15). The highest median concentration of total phosphorus $(0.045 \mathrm{mg} / \mathrm{L})$ was measured at
Little Blackfoot River near Garrison. Similar to the pattern observed for total nitrogen, median concentrations of total phosphorus were consistently higher in the Clark Fork subbasin compared to the Flathead or Kootenai River subbasins.

Median concentrations for total phosphorus were less than the general eutrophication guideline at all sites, and only a small number of samples had concentrations that exceeded this threshold. Total phosphorus concentrations in about 75 percent of samples collected at Clark Fork at Turah Bridge exceeded the seasonal reach-specific numeric standard of $0.020 \mathrm{mg} / \mathrm{L}$ for the Clark Fork mainstem; concentrations in about 25 percent of samples collected at Clark Fork at St. Regis exceeded the numeric standard of $0.039 \mathrm{mg} / \mathrm{L}$.

\section{Suspended Sediment}

In addition to nutrients, suspended sediment was a primary constituent that was analyzed in every sample collected for the statewide monitoring program. The availability of suspended sediment within a watershed depends on many factors such as local geology and soils, topography, vegetation, climate, and land use (Guy, 1970). These factors determine the susceptibility of the landscape to erosion and the rate of delivery of sediment to the streams. In addition, hydraulic characteristics, such as stream discharge and velocity, also determine the capacity of a stream to maintain sediment particles in suspension and transport the eroded sediment. Some constituents, such as trace elements, can bind to suspended-sediment particles and be transported in a particulate form (Horowitz, 1991; Lambing, 1991). Consequently, the concentrations of some chemical constituents vary in direct response to the amount of suspended sediment in a stream, which typically increases during periods of high streamflow or overland runoff. Statistical distributions of suspended-sediment concentration and particle size (percent finer than $0.062 \mathrm{~mm}$ ) at network sites are summarized in table 15.

The statistical distribution of suspended-sediment concentrations at network sites during water years 1999-2003 is shown in figure 11. Across the network, concentrations varied widely, both at individual sites and among sites in the network and ranged from 1 to $25,400 \mathrm{mg} / \mathrm{L}$ (table 15). Both the Missouri and Yellowstone River basins had similar patterns of variation in suspended-sediment concentrations-sites in the upper parts of the basin that are closer to mountain headwaters typically had lower concentrations than sites in the lower parts of the basin where streams drain extensive areas of semi-arid prairie underlain primarily by sedimentary rocks and deposits (Ross and others, 1955). In general, the lowest suspended-sediment concentrations were more commonly measured in the Columbia River basin, although some sites had concentrations similar to those measured in the upper parts of the Missouri and Yellowstone River basins.

In the Missouri River basin, suspended-sediment concentrations ranged from $1 \mathrm{mg} / \mathrm{L}$ at Prickly Pear Creek near Clancy and Dearborn River near Craig to 2,850 mg/L at Milk River 


\section{SUSPENDED SEDIMENT}

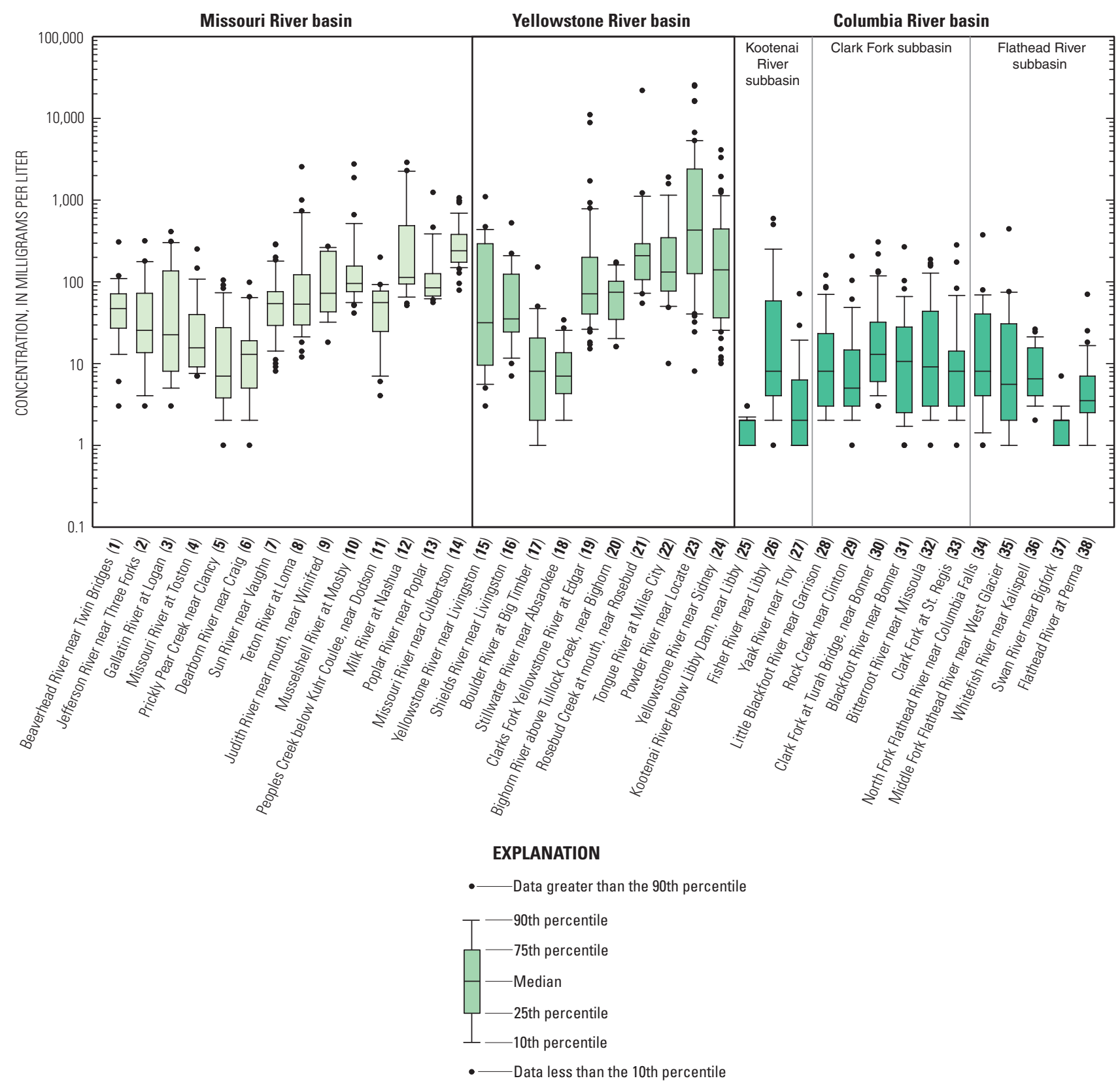

Note: When a data set contains multiple equal values, two or more of the percentile lines can overlap and result in a compressed plot

Figure 11. Statistical distribution of concentrations of suspended sediment at network sites in Montana, water years 1999-2003. Site number presented after station name (fig. 1, table 1). 
at Nashua (fig. 11, table 15). Minimum concentrations were less than $10 \mathrm{mg} / \mathrm{L}$ at all sites from the Sun River and upstream. Maximum concentrations of suspended sediment at five sites in the lower part of the Missouri River basin (Teton River near Loma, Musselshell River at Mosby, Milk River at Nashua, Poplar River near Poplar, and Missouri River near Culbertson) exceeded 1,000 mg/L.

Median suspended-sediment concentrations ranged from $7 \mathrm{mg} / \mathrm{L}$ at Prickly Pear Creek near Clancy to $237 \mathrm{mg} / \mathrm{L}$ at Missouri River near Culbertson (fig. 11, table 15). In general, suspended-sediment concentrations increased notably in the lower part of the basin from the Sun River downstream to Missouri River near Culbertson, where large portions of those basins drain semi-arid prairie areas and soils formed from sedimentary rocks and deposits. Three sites in the lower basin (Musselshell River at Mosby, Milk River at Nashua, and Missouri River near Culbertson) had median concentrations near or exceeding $100 \mathrm{mg} / \mathrm{L}$. Suspended-sediment concentrations at the two mainstem sites (Missouri River at Toston and Missouri River near Culbertson) were substantially different. The Missouri River near Toston had one of the lowest median concentrations (16 mg/L) among all the Missouri River basin sites, whereas Missouri River near Culbertson had the highest median concentration $(237 \mathrm{mg} / \mathrm{L})$ in the basin, representing about a 15-fold increase over that of the upper mainstem site.

In the Yellowstone River basin, suspended-sediment concentrations ranged from $1 \mathrm{mg} / \mathrm{L}$ at Boulder River at Big Timber to $25,400 \mathrm{mg} / \mathrm{L}$ at Powder River near Locate (fig. 11, table 15). The spatial pattern of suspended-sediment concentrations at sites in the Yellowstone River basin was similar to that in the Missouri River basin, where concentrations less than $10 \mathrm{mg} / \mathrm{L}$ most commonly occurred in the upper part of the basin (Stillwater River and upstream). The maximum suspended-sediment concentrations of 21,600 mg/L at Rosebud Creek near Rosebud was nearly as high as the maximum concentration $(25,400 \mathrm{mg} / \mathrm{L})$ at Powder River near Locate. Overall, suspended-sediment concentrations at Powder River near Locate were the highest in the statewide network, with more than 25 percent of the samples exceeding 2,000 mg/L.

Median suspended-sediment concentrations ranged from 7 and $8 \mathrm{mg} / \mathrm{L}$ at Stillwater River near Absarokee and Boulder River at Big Timber, respectively, to $426 \mathrm{mg} / \mathrm{L}$ at Powder River near Locate (fig. 11, table 15). Similar to the Missouri River, sites in the lower part of the Yellowstone River basin generally had the highest distribution of suspended-sediment concentrations, with four sites (Rosebud Creek near Rosebud, Tongue River at Miles City, Powder River near Locate, and Yellowstone River near Sidney) having median concentrations exceeding $100 \mathrm{mg} / \mathrm{L}$. Concentrations in the mainstem increased in a downstream direction from Yellowstone River near Livingston to Yellowstone River near Sidney, with the lower-mainstem site near Sidney having a median concentration $(137 \mathrm{mg} / \mathrm{L})$ more than 4-times greater than the uppermainstem site near Livingston (32 $\mathrm{mg} / \mathrm{L})$.

In the Columbia River basin, suspended-sediment concentrations ranged from $1 \mathrm{mg} / \mathrm{L}$ at many sites to $588 \mathrm{mg} / \mathrm{L}$ at Fisher River near Libby. Two sites, Kootenai River below Libby Dam and Swan River near Bigfork, had consistently low suspended-sediment concentrations due to their location downstream from large lakes or reservoirs. Minimum suspended-sediment concentrations at all sites in the Columbia River basin were $3 \mathrm{mg} / \mathrm{L}$ or less, with 11 of the 14 sites having minimum concentrations of $1 \mathrm{mg} / \mathrm{L}$. Maximum suspended-sediment concentrations ranged from $3 \mathrm{mg} / \mathrm{L}$ at Kootenai River below Libby Dam to $588 \mathrm{mg} / \mathrm{L}$ at Fisher River near Libby. Suspended-sediment concentrations exceeded $100 \mathrm{mg} / \mathrm{L}$ at only 9 of the 14 sites in the Columbia River basin. Median suspended-sediment concentrations were low relative to most sites in the Missouri and Yellowstone River basin and ranged from $2 \mathrm{mg} / \mathrm{L}$ at three sites (Kootenai River below Libby Dam, Yaak River near Troy, and Swan River near Bigfork) to $13 \mathrm{mg} / \mathrm{L}$ at Clark Fork at Turah Bridge (fig. 11, table 14); most median concentrations were less than $10 \mathrm{mg} / \mathrm{L}$.

\section{Major lons}

Major ions were a secondary constituent group that were analyzed only two times per year for the statewide monitoring program. The small number of samples limits the characterization of seasonal or hydrologic variations of concentrations. Generally, data were obtained that span the potential range of concentrations by sampling during high-flow and lowflow periods each year when annual minimum and maximum concentrations typically occur. Major ions that were analyzed include calcium, magnesium, sodium, potassium, alkalinity (an index of the sum of bicarbonate and carbonate), chloride, fluoride, silica, and sulfate (table 2). Statistical summaries of the individual major-ion concentrations measured in samples collected at network sites during water years 1999-2003 are presented in table 15.

Major ions constitute most of the dissolved constituents in water (Hem, 1985). Several water-quality indicators can be calculated from major-ion concentrations, such as hardness, dissolved solids, and sodium adsorption ratio (SAR). Hardness is calculated from calcium and magnesium concentrations and converted to an equivalent concentration of calcium carbonate (Fishman and Friedman, 1989). Hardness is used to determine aquatic-life toxicity standards for several trace elements (cadmium, chromium, copper, lead, nickel, and zinc) whose degree of toxicity varies with water hardness. An increase in hardness decreases metal toxicity because cations, such as calcium and magnesium, compete with metals for binding sites on biological membranes (Playle, 2004). Dissolved solids (also commonly referred to as total-dissolved solids, or TDS) represent the concentration of all dissolved material in water. Typically, the dissolved solids are composed almost entirely of the major ions. The concentration of dissolved solids can either be measured directly as a gravimetric analysis of the mass of an evaporated filtered sample, or it can be estimated by summing the individual major-ion concentrations, after converting alkalinity to an equivalent calcium carbonate concentration 
(Fishman and Friedman, 1989; p. 459-460). In the statewide monitoring program, dissolved solids were calculated as the "sum of constituents" (table 15). For this report, sum of constituents will be referred to as "dissolved solids."

Dissolved-solids concentration is a general indicator of water quality, as it represents a measure of the salt content (salinity) in water, which can affect many water uses including irrigation, livestock watering, or domestic-drinking water. Another water-quality indicator of salinity determined from selected major-ion concentrations is the SAR, which is used as an indicator of the suitability of water for irrigation. SAR is calculated from the relative proportion of the concentrations of the cations sodium, calcium, and magnesium. SAR values indicate the likelihood that irrigation water will generate cation-exchange reactions in soils, whereby calcium and magnesium ions attached to the soil are replaced by sodium ions from the applied water. This increased proportion of sodium in the soil can damage soil structure by decreasing infiltration capacity and permeability, as well as causing surface crusting when dry (U.S. Department of Agriculture, 2002).

Statistical summaries of calculated values for hardness, dissolved solids, and SAR are presented in table 15. Two of the indicators of water quality determined from major-ion concentrations, dissolved solids and SAR, are discussed in more detail in the following sections.

\section{Dissolved Solids}

The statistical distribution of dissolved-solids concentrations at network sites during water years 1999-2003 is shown in figure 12. Across the network, concentrations varied widely, ranging from 23 to $6,200 \mathrm{mg} / \mathrm{L}$ (table 15). Concentrations of dissolved solids commonly increased during conditions of low streamflow. In the Missouri and Yellowstone River basins, the highest values commonly occurred at sites in the lower part of the basins that drain extensive areas of semi-arid prairie. Upper-basin sites that have a large portion of their drainage area in wetter mountainous terrain had substantially lower dissolved-solids concentrations. In general, sites in the Columbia River basin had consistently low dissolved-solids concentrations. The U.S. Environmental Protection Agency (1986) recommends not exceeding a dissolved-solids concentration of $1,000 \mathrm{mg} / \mathrm{L}$ as a general irrigation guideline to prevent adverse effects on many crops (fig. 12).

In the Missouri River basin, dissolved-solids concentrations ranged from $75 \mathrm{mg} / \mathrm{L}$ at Prickly Pear Creek near Clancy to $6,200 \mathrm{mg} / \mathrm{L}$ at Musselshell River at Mosby (table 15). Median dissolved-solids concentrations ranged from $168 \mathrm{mg} / \mathrm{L}$ at Prickly Pear Creek near Clancy to $1,740 \mathrm{mg} / \mathrm{L}$ at Musselshell River at Mosby (fig. 12, table 15). Tributaries in the upper basin (Sun River and upstream), as well as the two mainstem sites (Missouri River at Toston and Missouri River near Culbertson), had relatively low dissolved-solids concentrations and a generally small range of variation. Dissolvedsolids concentrations generally increased in the tributaries downstream from the Sun River. One site, Musselshell River at Mosby, had notably higher dissolved-solids concentrations compared to the other sites. The maximum dissolved-solids concentration $(6,200 \mathrm{mg} / \mathrm{L})$ at this site was about 4 to 30 times larger than maximum values at other sites in the basin. This high concentration was measured in a sample collected during a time of extreme low flow $\left(0.03 \mathrm{ft}^{3} / \mathrm{s}\right)$. Musselshell River at Mosby also had the largest range in dissolved-solids concentrations indicating that various factors, possibly relating to flow conditions, might be affecting the dissolved-solids concentrations in this stream. About 90 percent of the samples collected at Musselshell River at Mosby exceeded the general irrigation guideline of $1,000 \mathrm{mg} / \mathrm{L}$. Three other sites in the Missouri River basin (Peoples Creek near Dodson, Milk River at Nashua, and Poplar River near Poplar) had dissolved-solids concentrations that exceeded the $1,000 \mathrm{mg} / \mathrm{L}$ general irrigation guideline in about 25 to 50 percent of the samples.

In the Yellowstone River basin, dissolved-solids concentrations ranged from $26 \mathrm{mg} / \mathrm{L}$ at the Stillwater River near Absarokee to 2,450 mg/L at Rosebud Creek near Rosebud (table 15). Median dissolved-solids concentrations ranged from $59 \mathrm{mg} / \mathrm{L}$ at Stillwater River near Absarokee to $1,870 \mathrm{mg} / \mathrm{L}$ at Rosebud Creek near Rosebud (fig. 12, table 15). Similar to the Missouri River basin, dissolved-solids concentrations generally increased in a downstream direction; samples from sites in the upper part of the basin (Stillwater River and upstream) had relatively low concentrations. Rosebud Creek near Rosebud and Powder River near Locate consistently had the highest dissolved-solids concentrations and were the only two sites in the basin with concentrations that exceeded the general irrigation guideline of $1,000 \mathrm{mg} / \mathrm{L}$; the guideline was exceeded in more than 75 percent of the samples from both sites.

In the Columbia River basin, dissolved-solids concentrations ranged from $23 \mathrm{mg} / \mathrm{L}$ at Yaak River near Troy to $257 \mathrm{mg} / \mathrm{L}$ at Clark Fork at Turah Bridge (table 15). Median concentrations ranged from $52 \mathrm{mg} / \mathrm{L}$ at Yaak River near Troy to $209 \mathrm{mg} / \mathrm{L}$ at Clark Fork at Turah Bridge. Dissolved-solids concentrations did not vary substantially with flow or season during the monitoring period and did not exceed the general irrigation guideline.

\section{Sodium Adsorption Ratio}

The SAR provides an indication of the degree to which sodium in water will be adsorbed by soil. The effects of SAR vary with the specific soil characteristics and other factors, such as salinity, which makes it difficult to evaluate the suitability of water for irrigation using a generalized SAR guideline value. The U.S. Department of Agriculture (2002) has recommended as a general irrigation guideline that water having an SAR of greater than 7 not be used for irrigation. In the Yellowstone River basin, basin-specific numeric standards for SAR have been established for the Rosebud Creek, Tongue River, and Powder River watersheds. In the Rosebud Creek and Tongue River mainstems, the monthly average SAR value is not to exceed 3.0 and a discrete sample value is not 


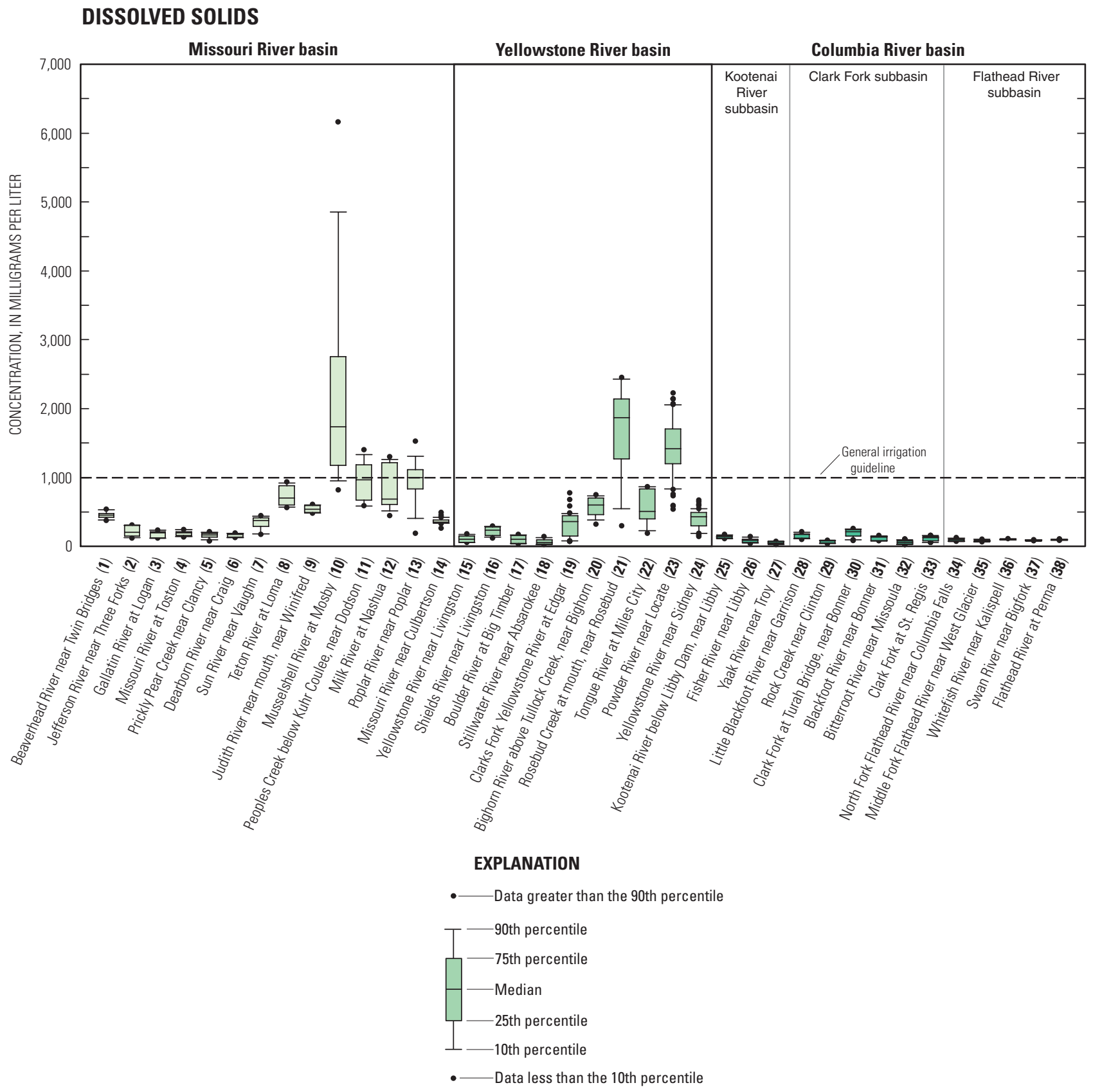

Note: When a data set contains multiple equal values, two or more of the percentile lines can overlap and result in a compressed plot

Figure 12. Statistical distribution of concentrations of dissolved solids at network sites in Montana, water years 1999-2003. Site number presented after station name (fig. 1, table 1). The general irrigation guideline provided by the U.S. Environmental Protection Agency (1986) is 1,000 milligrams per liter. 
to exceed 4.5 during the irrigation season of March 2 through October 31 (Montana Department of Environmental Quality, 2003). For the Powder River mainstem during the irrigation season, the SAR standards are 5.0 for a monthly average and 7.5 for a discrete sample. Somewhat higher values are designated for all of these mainstems during the non-irrigation season (November 1 through March 1), with SAR standards ranging from 5.0 to 6.5 for monthly averages, and from 7.5 to 9.75 for discrete samples. Basin-specific numeric standards established for irrigation-season discrete samples are shown in figure 13 because these standards represent the season when most of the samples were collected.

The statistical distribution of SAR values for network sites during water years 1999-2003 is shown in figure 13 . Across the network, SAR values ranged from $<0.1$ to 12 among all the sites (table 15). Several sites in the lower Missouri and Yellowstone River basins had SAR values that exceeded the general irrigation guideline of 7. All of the sites in the Columbia River basin had consistently low SAR values ( 0.4 or less) that were less than the general irrigation guideline.

In the Missouri River basin, SAR ranged from $<0.1$ at Dearborn River near Craig to 11 at Poplar River near Poplar (fig. 13, table 15). Median SAR values ranged from 0.1 at Dearborn River near Craig to 8 at Poplar River near Poplar. Tributaries in the upper part of the basin (Judith River and upstream) and both mainstem sites (Missouri River at Toston and Missouri River near Culbertson), typically had relatively low SAR values of 2 or less. SAR values at four tributaries in the lower Missouri River basin (Musselshell River at Mosby, Peoples Creek near Dodson, Milk River at Nashua, and Poplar River near Poplar) were elevated relative to the other sites in the basin, with median SAR values ranging from 4 to 8 .

The general irrigation guideline of 7 was exceeded in more than 25 percent of the samples at Musselshell River at Mosby and Peoples Creek near Dodson, and in more than 50 percent of the samples at Poplar River near Poplar (fig. 13). Consequently, the sodium content of the water in these three lower-basin tributaries could potentially be detrimental to soils if fields were irrigated during periods of high SAR in the streams.

In the Yellowstone River basin, SAR ranged from 0.1 at Boulder River at Big Timber and Stillwater River near Absarokee to 12 at Rosebud Creek near Rosebud (fig. 13, table 15). Median SAR values ranged from 0.2 at Boulder River at Big Timber and Stillwater River near Absarokee to 6 at Rosebud Creek near Rosebud. SAR values at most tributaries and both Yellowstone River mainstem sites were relatively low (typically about 2 or less). Three tributaries in the lower part of the basin (Rosebud Creek near Rosebud, Tongue River at Miles City, and Powder River near Locate) had SAR values that were elevated relative to other sites in the basin. Seventy-five percent of the samples collected at Rosebud Creek near Rosebud had SAR values that exceeded the irrigation-season numeric standard of 4.5 for discrete samples (fig. 13). The same SAR numeric standards for Rosebud Creek apply to Tongue River at
Miles City, but none of the samples collected at Tongue River at Miles City exceeded the irrigation-season SAR numeric standard of 4.5 for discrete samples. SAR values at Powder River near Locate occasionally exceeded the irrigation-season numeric standard of 7.5 for discrete samples. Because SAR values in Rosebud Creek and Powder River periodically exceeded the numeric standards, the sodium content of the water in these two streams could potentially be detrimental to soils if fields were irrigated during periods of high SAR in the streams. Even though no samples collected at Tongue River at Miles City exceeded the numeric standard of 4.5, the maximum value (4) approached the standard and some caution may be warranted.

In the Columbia River basin, SAR values ranged from 0.1 or less at several sites to 0.4 at Clark Fork at Turah Bridge and Clark Fork at St. Regis. Median SAR values were equal to or less than 0.3 (fig. 13, table 15). SAR values were well below the general irrigation guideline; consequently, water used for irrigation from these streams would not pose a sodium risk to soil.

\section{Trace Elements}

Similar to major ions, trace elements were a secondary constituent group that were analyzed only two times per year for the statewide monitoring program. The small number of samples limits the characterization of seasonal and hydrologic variations of concentrations. Generally, data were obtained that span the potential range of concentrations by sampling during high-flow and low-flow periods each year when annual minimum and maximum concentrations typically occur. Totalrecoverable concentrations of arsenic, cadmium, chromium, copper, lead, nickel, and zinc were analyzed for this monitoring program (table 2). Statistical summaries of trace-element concentrations measured in samples collected at network sites during water years 1999-2003 are presented in table 15.

Elevated trace-element concentrations can have detrimental effects on both aquatic and terrestrial biota, including humans (U.S. Environmental Protection Agency, 1986). Both natural and anthropogenic sources can contribute to elevated trace-element concentrations in streams (Hem, 1985). Natural sources can include geothermal water that discharges to the surface, or ground water that drains through mineralized rocks and deposits. Mining, which can generate mine wastes such as tailings or create acidic drainage, also can lead to elevated trace-element concentrations in streams. Examples of elevated trace-element concentrations and geochemical processes resulting from mining in Montana are described in Kimball and others (1999) and Nimick and others (2004). In general, due to the tendency for many trace elements to adsorb onto sediment particles (Horowitz, 1991; Lambing, 1991), concentrations of total-recoverable trace elements tend to increase when suspended-sediment concentrations increase, which is most common during periods of increased streamflow during rainfall or snowmelt runoff. 


\section{SODIUM ADSORPTION RATIO}

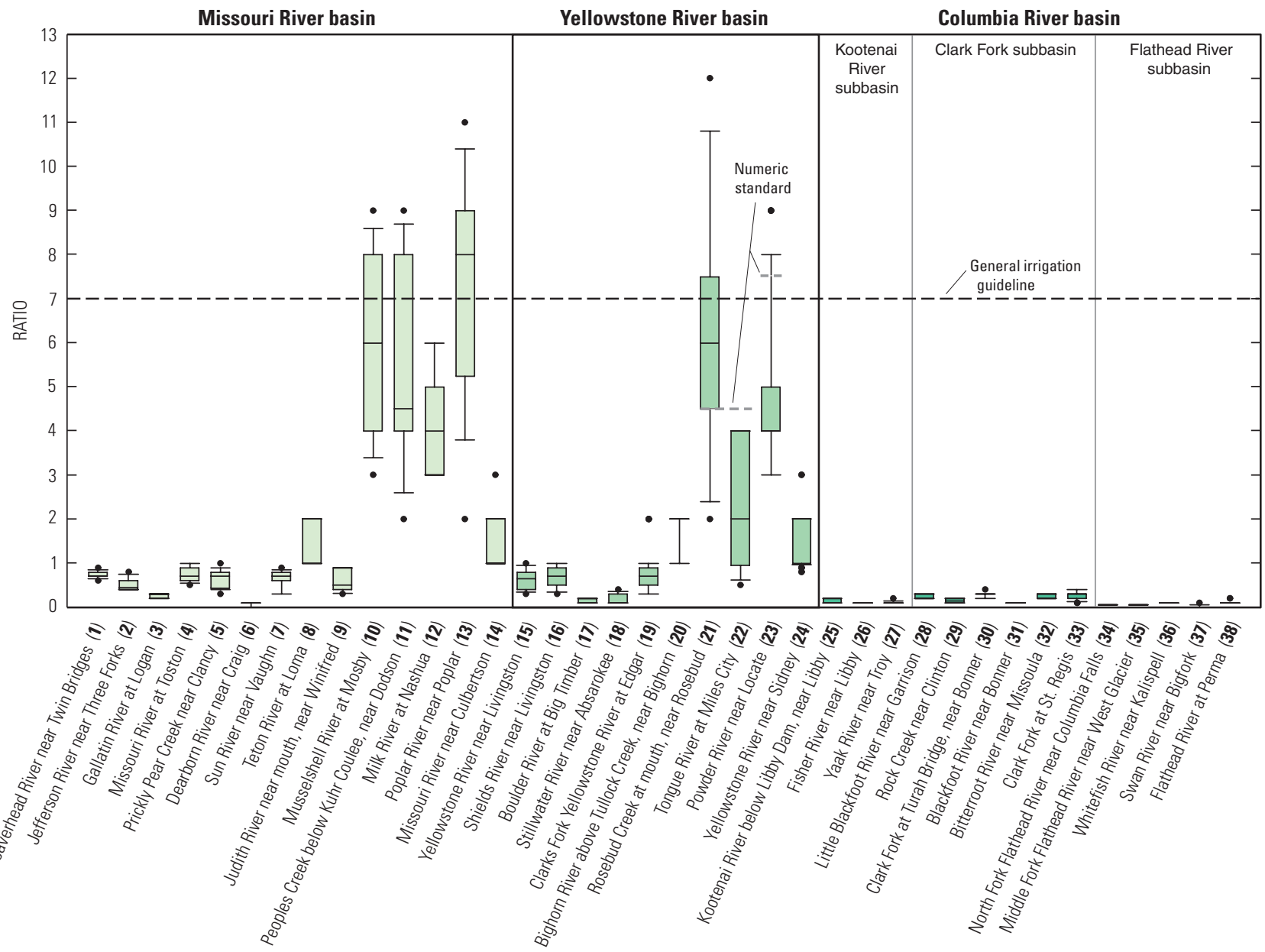

EXPLANATION

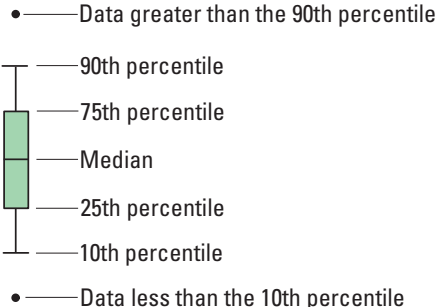

Note: When a data set contains multiple equal values, two or more of the percentile lines can overlap and result in a compressed plot

Figure 13. Statistical distribution of sodium adsorption ratio (SAR) at network sites in Montana, water years 1999-2003. Site number presented after station name (fig. 1, table 1). The State of Montana numeric standards (Montana Department of Environmental Quality, 2003) of 4.5 and 7.5 represent the basin-specific maximum allowable values for samples collected during the irrigation season, March 2 through October 31. The general irrigation guideline provided by the U.S. Department of Agriculture (2002) is 7. 
Human-health standards for drinking-water supplies and numeric standards for the protection of freshwater aquatic life have been established by the State of Montana for several trace elements (Montana Department of Environmental Quality, 2004). Aquatic-life standards are represented by two levels of toxicity effects - chronic and acute (U.S. Environmental Protection Agency, 1986). Chronic toxicity is commonly a long-term effect where functional impairment can occur to biota exposed to concentrations that exceed chronic standards for extended periods of time (96 hours or more). Chronic toxicity generally does not cause death directly, but can affect the growth, reproduction, or other biological activities necessary to sustain a healthy population of aquatic organisms. Acute toxicity commonly is manifested by death within a relatively short time as the result of exposure to concentrations that exceed acute standards for periods as brief as 1 hour. Acute toxicity can sometimes affect large numbers of the aquatic population.

The degree of toxicity to aquatic life from cadmium, chromium, copper, lead, nickel, and zinc varies with the ambient hardness of the water; therefore, aquatic-life standards are calculated on a site-specific and sample-specific basis to allow for direct comparison of sample concentrations to standards (Montana Department of Environmental Quality, 2004). However, to summarize analytical results for all samples collected at a site, a general aquatic-life standard was used for comparison to the overall distribution of trace-element concentrations. Thus, general hardness-dependent standards (chronic and acute) were calculated for each trace element using the average hardness for groups of sites having generally similar hardness values (table 5). The general standards, which vary among sites, are intended only to provide a reference for comparison of sample data to approximate thresholds of potential toxicity and to illustrate relative differences among groups of sites. Such relative measures of comparison cannot be used to identify when standards are exceeded, but they can be useful to indicate if concentrations persistently pose a potential risk to aquatic biota. Determination of actual exceedances would require that aquatic-life standards be calculated for each sample.

\section{Total-Recoverable Arsenic}

The statistical distribution of total-recoverable arsenic concentrations at network sites during water years 1999-2003 is shown in figure 14. The State of Montana human-health standard of $18 \mu \mathrm{g} / \mathrm{L}$ for arsenic (Montana Department of Environmental Quality, 2004) is shown in the figure as a general reference to potential toxicity. Aquatic-life standards for arsenic are not shown because all sample concentrations were substantially lower than the chronic aquatic-life standard of $150 \mu \mathrm{g} / \mathrm{L}$ (Montana Department of Environmental Quality, 2004).

Across the network, concentrations ranged from $<1$ to $48 \mu \mathrm{g} / \mathrm{L}$ (fig. 14, table 15). In general, water from most sites in the network had arsenic concentrations less than the State of Montana human-health standard. At one or more sites in each of the three major river basins, arsenic concentrations exceeded the human-health standard (fig. 14). At some of those sites, arsenic concentrations exceeded the standard in only a few samples. However, at two sites arsenic concentrations commonly exceeded the standard: Missouri River at Toston and Yellowstone River near Livingston. Geothermal water from Yellowstone National Park contributes large quantities of arsenic to the headwaters of the Missouri and Yellowstone Rivers (Nimick and others, 1998).

Table 5. General aquatic-life standards calculated from average hardness for groups of network sites with similar hardness, Montana.

[Abbreviations: $\mathrm{CaCO}_{3}$, calcium carbonate; $\mu \mathrm{g} / \mathrm{L}$, micrograms per liter; $\mathrm{mg} / \mathrm{L}$, milligrams per liter]

\begin{tabular}{|c|c|c|c|c|c|c|c|}
\hline \multirow{2}{*}{$\begin{array}{c}\text { Site numbers } \\
\text { for groups } \\
\text { of sites with } \\
\text { similar hardness } \\
\text { (table } 1 \text { and } \\
\text { fig. 1) }\end{array}$} & \multirow{2}{*}{$\begin{array}{c}\text { Average } \\
\text { hardness, } \\
\mathrm{mg} / \mathrm{L} \text { as } \mathrm{CaCO}_{3}\end{array}$} & \multicolumn{6}{|c|}{$\begin{array}{l}\text { General aquatic-life standards ( } \mu \mathrm{g} / \mathrm{L} \text { ) for average hardness }{ }^{1} \\
\text { (chronic/acute) }\end{array}$} \\
\hline & & Cadmium & Chromium & Copper & Lead & Nickel & Zinc \\
\hline $1-6$ & 168 & $0.37 / 3.2$ & $120 / 2,500$ & $13 / 20$ & $5.3 / 140$ & $74 / 660$ & $170 / 170$ \\
\hline $7-14$ & 303 & $.63 / 6.7$ & $220 / 4,500$ & $24 / 41$ & $13 / 340$ & $140 / 1,200$ & $310 / 310$ \\
\hline $15-18$ & 104 & $.24 / 1.8$ & $76 / 1,600$ & $8.2 / 12$ & $2.6 / 67$ & $46 / 410$ & $100 / 100$ \\
\hline $19-24$ & 337 & $.67 / 7.4$ & $230 / 4,900$ & $26 / 44$ & $15 / 390$ & $150 / 1,300$ & $340 / 340$ \\
\hline $25-38$ & 112 & $.26 / 2.0$ & $81 / 1,700$ & $8.8 / 13$ & $2.9 / 74$ & $49 / 440$ & $110 / 110$ \\
\hline
\end{tabular}

${ }^{1}$ General aquatic-life standards are calculated from equations in Montana Department of Environmental Quality (2004) using average hardness for each group. General aquatic-life standards are not legally enforceable values, but are presented to provide a basis to illustrate relative differences among groups of sites (figs. 15-20). The first number is the calculated standard for chronic toxicity; the second number is the calculated standard for acute toxicity. 


\section{TOTAL-RECOVERABLE ARSENIC}

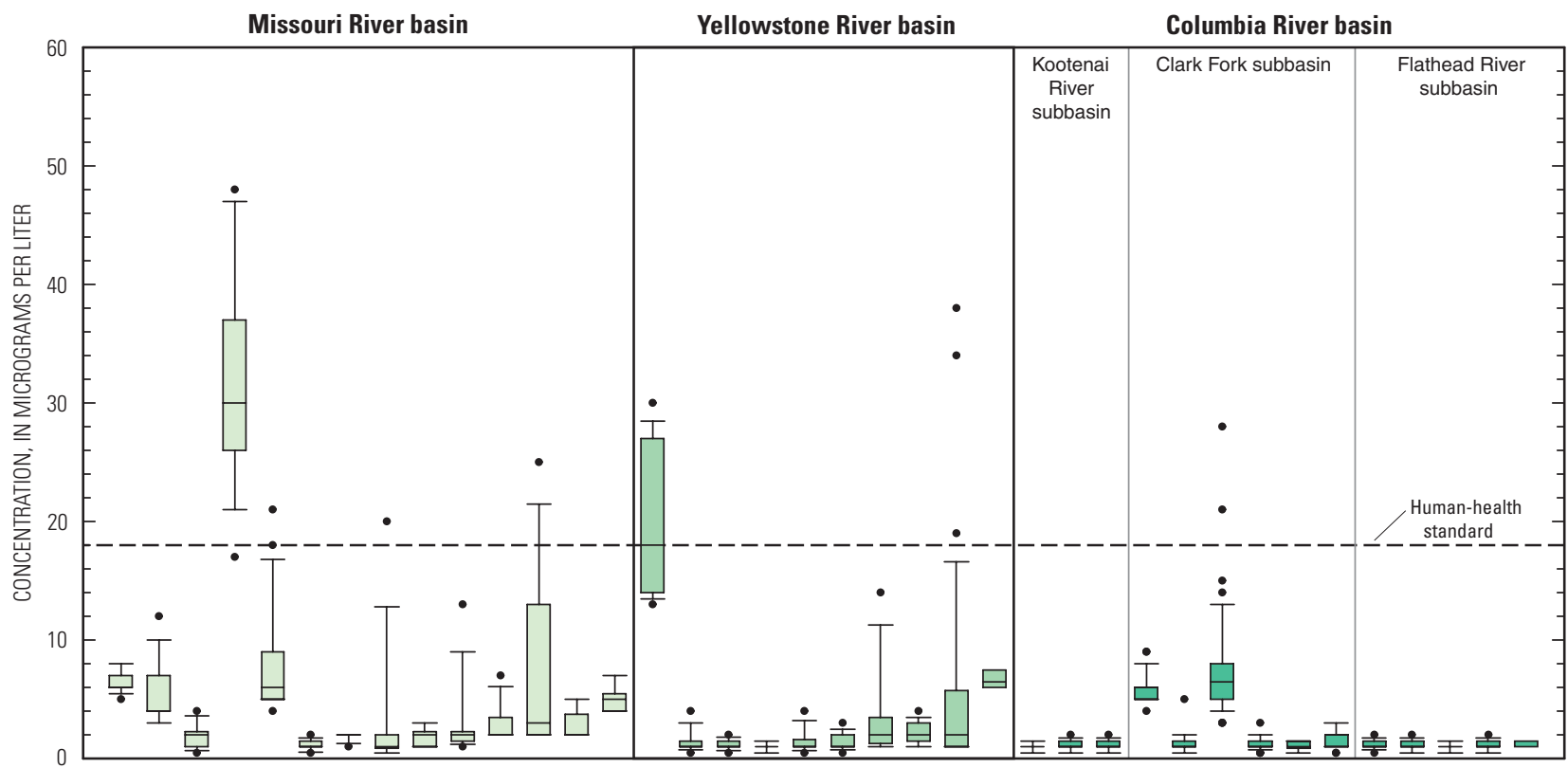

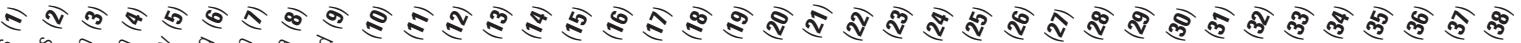

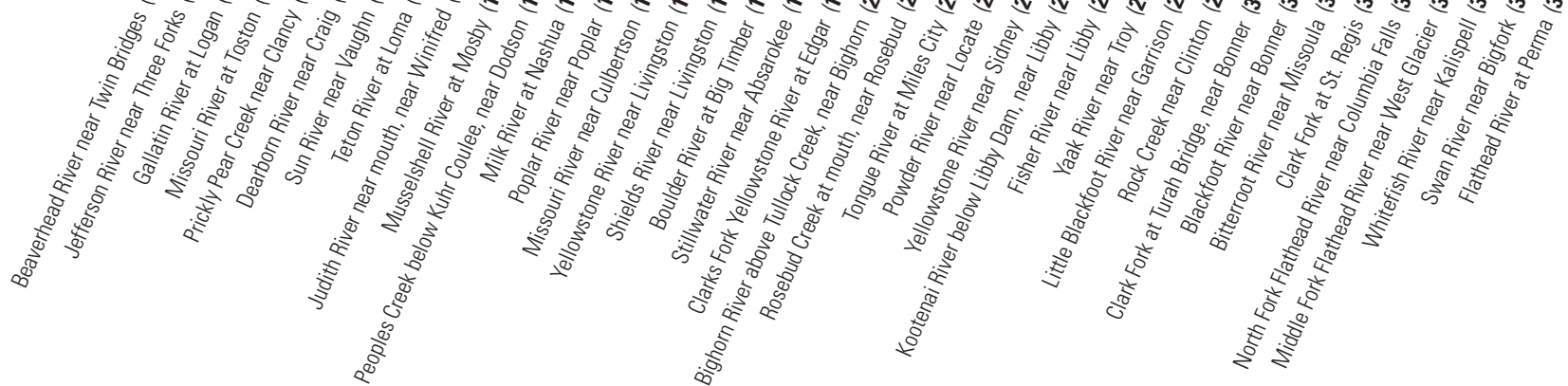

EXPLANATION

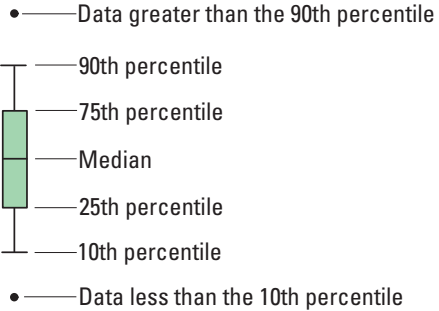

Note: When a data set contains multiple equal values, two or more of the percentile lines can overlap and result in a compressed plot

Figure 14. Statistical distribution of concentrations of total-recoverable arsenic at network sites in Montana, water years 1999-2003. Site number presented after station name (fig. 1, table 1). The State of Montana human-health standard is 18 micrograms per liter (Montana Department of Environmental Quality, 2004). Concentrations reported as less than the laboratory reporting level are plotted as one-half the maximum laboratory reporting level. 
In the Missouri River basin, total-recoverable arsenic concentrations ranged from less than $1 \mu \mathrm{g} / \mathrm{L}$ at Gallatin River at Logan, Dearborn River near Craig, and Teton River at Loma to $48 \mu \mathrm{g} / \mathrm{L}$ at Missouri River at Toston. The arsenic concentrations at Missouri River at Toston were substantially elevated compared to the other sites in the Missouri River basin. Median total-recoverable arsenic concentrations ranged from less than $2 \mu \mathrm{g} / \mathrm{L}$ at several sites to $30 \mu \mathrm{g} / \mathrm{L}$ at Missouri River at Toston, with most sites having median concentrations of $6 \mu \mathrm{g} / \mathrm{L}$ or less (fig. 14, table 15).

Almost all samples collected at Missouri River at Toston exceeded the State of Montana human health standard of $18 \mu \mathrm{g} / \mathrm{L}$ for arsenic. Arsenic concentrations in samples from three other sites (Prickly Pear near Clancy, Teton River at Loma, and Milk River at Nashua) occasionally exceeded the human-health standard. Although samples from Missouri River at Toston and several tributaries frequently or occasionally had elevated arsenic concentrations, samples from the Missouri River near Culbertson did not have any samples where arsenic concentrations exceeded $7 \mu \mathrm{g} / \mathrm{L}$, indicating that downstream either arsenic in water was diluted by tributary inflow or arsenic was sorbed onto suspended sediment and deposited in the mainstem or in reservoirs (Nimick and others, 1998).

In the Yellowstone River basin, total-recoverable arsenic concentrations range from $<1 \mu \mathrm{g} / \mathrm{L}$ at many sites to $38 \mu \mathrm{g} / \mathrm{L}$ at Powder River near Locate. Total-recoverable arsenic concentrations at Yellowstone River near Livingston were consistently elevated compared to most other Yellowstone River basin sites. Median total-recoverable arsenic concentrations ranged from $2 \mu \mathrm{g} / \mathrm{L}$ or less at several sites to $18 \mu \mathrm{g} / \mathrm{L}$ at Yellowstone River near Livingston (fig. 14, table 15). Median concentrations at the other sites in the Yellowstone River basin were $7 \mu \mathrm{g} / \mathrm{L}$ or less.

About one-half of the samples from Yellowstone River at Livingston had total-recoverable arsenic concentrations that exceeded the human-health standard of $18 \mu \mathrm{g} / \mathrm{L}$. Powder River near Locate was the only other site in the basin where arsenic concentrations in several samples exceeded the human-health standard.

In the Columbia River basin, total-recoverable arsenic concentrations ranged from $<1 \mu \mathrm{g} / \mathrm{L}$ at many sites to $28 \mu \mathrm{g} / \mathrm{L}$ at Clark Fork at Turah Bridge. Most of the maximum concentrations were $5 \mu \mathrm{g} / \mathrm{L}$ or less. Median total-recoverable arsenic concentrations ranged from less than $2 \mu \mathrm{g} / \mathrm{L}$ at most sites to $6 \mu \mathrm{g} / \mathrm{L}$ at Little Blackfoot River near Garrison and Clark Fork at Turah Bridge (fig. 14, table 15).

Only Clark Fork at Turah Bridge had samples with arsenic concentrations exceeding the human-health standard. This site is located downstream from an area that has had a long history of large-scale mining in its headwaters and elevated trace-element concentrations in the stream (Lambing, 1991).

\section{Total-Recoverable Cadmium}

The statistical distribution of total-recoverable cadmium concentrations at network sites during water years 1999-2003 is shown in figure 15. The State of Montana human-health standard of $5 \mu \mathrm{g} / \mathrm{L}$ and general aquatic-life standards for various levels of hardness (Montana Department of Environmental Quality, 2004) are shown in the figure as a general reference to potential toxicity. During the monitoring period, the LRL for cadmium varied substantially from 0.04 to $1 \mu \mathrm{g} / \mathrm{L}$; however, the high LRL of $1 \mu \mathrm{g} / \mathrm{L}$ was used only during the first year of the monitoring period (1999). Plotting these censored values using one-half the LRL is problematic because one-half of the LRL $(0.5 \mu \mathrm{g} / \mathrm{L})$ is still an order of magnitude greater than the more recent LRL of $0.04 \mu \mathrm{g} / \mathrm{L}$. Concentrations of cadmium in many stream samples analyzed with the lower LRL were less than $0.04 \mu \mathrm{g} / \mathrm{L}$; consequently, the earlier censored values of less than $1 \mu \mathrm{g} / \mathrm{L}$ could not be reasonably adjusted to a plotting value that could be combined and statistically summarized with the more recent data. The aquatic-life standard for cadmium in water having low hardness can be less than $0.5 \mu \mathrm{g} / \mathrm{L}$; thus, using one-half of the LRL of $1 \mu \mathrm{g} / \mathrm{L}$ might mistakenly be interpreted as an exceedance of the aquatic-life standards. As a result, cadmium concentrations that were reported as $<1 \mu \mathrm{g} / \mathrm{L}$ during 1999 were not used to calculate statistics for the boxplots (fig. 15).

Across the network, total-recoverable cadmium concentrations ranged from $<0.04$ to $10 \mu \mathrm{g} / \mathrm{L}$ (table 15). Although concentrations consistently were less than $1 \mu \mathrm{g} / \mathrm{L}$ at most sites, at least one site in every major river basin had one or more samples exceeding $1 \mu \mathrm{g} / \mathrm{L}$. Only two samples from one site in the Yellowstone River basin exceeded the human-health standard of $5 \mu \mathrm{g} / \mathrm{L}$ for cadmium, but several sites had one or more samples that exceeded general aquatic-life standards. The occasional elevated cadmium concentrations did not seem to display any consistent spatial pattern.

In the Missouri River basin, total-recoverable cadmium concentrations ranged from $<0.04 \mu \mathrm{g} / \mathrm{L}$ at several sites to $1.2 \mu \mathrm{g} / \mathrm{L}$ at Prickly Pear Creek near Clancy. Many concentrations were less than the LRL. Almost all median concentrations were less than $0.2 \mu \mathrm{g} / \mathrm{L}$. The median concentration for Prickly Pear Creek near Clancy $(0.2 \mu \mathrm{g} / \mathrm{L})$ was slightly elevated compared to the other sites in the basin (fig. 15, table 15). Historical hard-rock mining occurred in the headwaters of this creek and elevated cadmium concentrations are likely due to metal-rich drainage and sediment derived from the mined areas (Klein and others, 2003).

All cadmium concentrations in the Missouri River basin were well below the human-health standard of $5 \mu \mathrm{g} / \mathrm{L}$. Only two sites, Jefferson River near Three Forks and Prickly Pear Creek near Clancy, had concentrations in samples that occasionally exceeded the general chronic aquatic-life standard for cadmium. 
TOTAL-RECOVERABLE CADMIUM

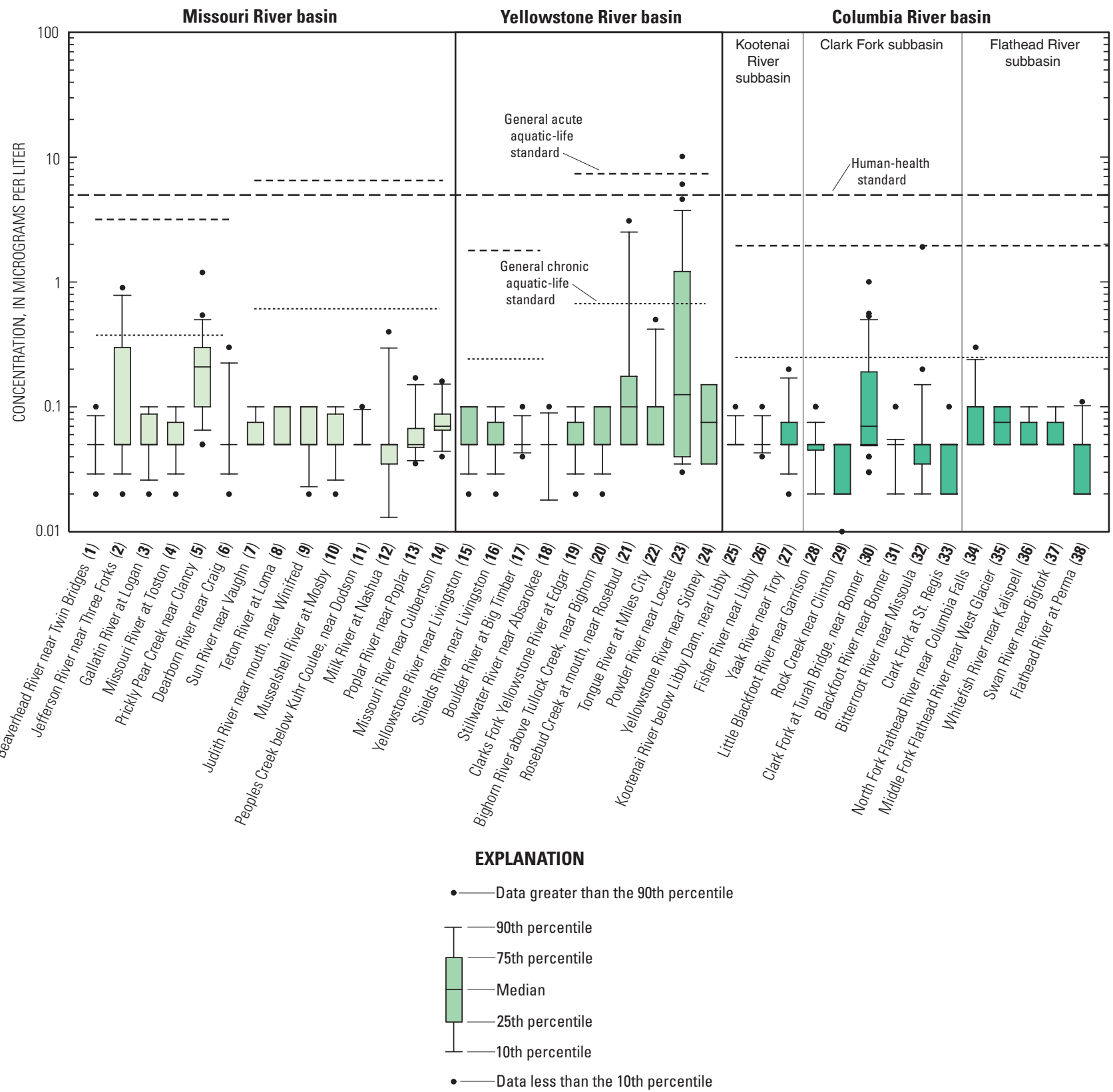

Note: When a data set contains multiple equal values, two or more of the percentile lines can overlap and result in a compressed plot

Figure 15. Statistical distribution of concentrations of total-recoverable cadmium at network sites in Montana, water years 1999-2003. Site number presented after station name (fig. 1, table 1). The State of Montana human-health standard is 5 micrograms per liter. The general aquatic-life standards for acute and chronic toxicity (table 5) were calculated using applicable equations (Montana Department of Environmental Quality, 2004) and average water hardness. Variable aquaticlife standards result from differences in the average water hardness among groups of sites. Cadmium values with a high laboratory reporting level of 1 microgram per liter during 1999 at 34 sites were not used to calculate statistics for this figure. Concentrations reported as less than lower laboratory reporting levels are plotted as one-half the maximum laboratory reporting level. 
In the Yellowstone River basin, total-recoverable cadmium concentrations ranged from $<0.04 \mu \mathrm{g} / \mathrm{L}$ at several sites to $10 \mu \mathrm{g} / \mathrm{L}$ at Powder River near Locate (fig. 15, table 15 ). Total-recoverable cadmium concentrations were commonly less than the LRL. Median concentrations were less than $0.2 \mu \mathrm{g} / \mathrm{L}$ at all sites. Although the median total-recoverable cadmium concentration $(0.1 \mu \mathrm{g} / \mathrm{L})$ at Powder River near Locate was relatively low and similar to median concentrations at several other sites in the basin, values in the upper 50 percent of the statistical distribution of concentrations at this site vary extensively. This variability is probably related to the large range of suspended-sediment concentrations typical of this stream (fig. 11) and the affinity for trace elements like cadmium to adsorb to sediment.

Only one site (Powder River near Locate) had concentrations that exceeded the human-health standard in two samples. The maximum total-recoverable cadmium concentration $(10 \mu \mathrm{g} / \mathrm{L})$ at this site was twice as high as the human-health standard and also was the highest concentration measured in the statewide network. In addition, more than 25 percent of the samples collected at Powder River near Locate exceeded the general chronic aquatic-life standard for cadmium, with the maximum concentration exceeding the general acute standard. One other site in the basin, Rosebud Creek near Rosebud, had concentrations that exceeded the general chronic aquatic-life standard.

In the Columbia River basin, total-recoverable cadmium concentrations ranged from $<0.04 \mu \mathrm{g} / \mathrm{L}$ at several sites to $1.9 \mu \mathrm{g} / \mathrm{L}$ at Bitterroot River near Missoula (fig. 15, table 15); concentrations generally were less than the LRL. Median concentrations at all sites were less than $0.2 \mu \mathrm{g} / \mathrm{L}$. The general chronic aquatic-life standard was exceeded most frequently in samples from Clark Fork at Turah Bridge, occurring in more than 10 percent of the samples. The concentration of cadmium in one sample from Bitterroot River near Missoula and North Fork Flathead River near Columbia Falls exceeded the general chronic aquatic-life standard; the concentration of cadmium $(1.9 \mu \mathrm{g} / \mathrm{L})$ in the sample from Bitterroot River near Missoula was nearly equal to the general acute aquatic-life standard.

\section{Total-Recoverable Chromium}

The statistical distribution of total-recoverable chromium concentrations at network sites during water years 1999-2003 is shown in figure 16. The State of Montana human-health standard of $100 \mu \mathrm{g} / \mathrm{L}$ for chromium and the general chronic aquatic-life standards for various levels of hardness (Montana Department of Environmental Quality, 2004) are shown in the figure as a general reference to potential toxicity. General acute aquatic-life standards are not plotted because all sample concentrations were well below the standards.

Across the network, concentrations ranged from $<0.8$ to $149 \mu \mathrm{g} / \mathrm{L}$ (table 15). In general, chromium concentrations were low relative to both the human-health standard and aquatic-life standards. Only two sites in the Yellowstone River basin had concentrations exceeding the human-health standard; none of the sites in the statewide network had concentrations that exceeded general chronic aquatic-life standards for chromium.

In the Missouri River Basin, total-recoverable chromium concentrations ranged from $<0.8 \mu \mathrm{g} / \mathrm{L}$ at several sites to $36.7 \mu \mathrm{g} / \mathrm{L}$ at Teton River at Loma (fig. 16, table 15). Three sites (Teton River at Loma, Musselshell River at Mosby, and Milk River at Nashua) had at least one sample with a chromium concentration that exceeded $20 \mu \mathrm{g} / \mathrm{L}$. Median totalrecoverable chromium concentrations were $2 \mu \mathrm{g} / \mathrm{L}$ or less at all sites. None of the samples collected in the Missouri River basin had total-recoverable chromium concentrations that exceeded the State of Montana human-health standard or general aquatic-life standards.

In the Yellowstone River basin, total-recoverable chromium concentrations ranged from $<0.8 \mu \mathrm{g} / \mathrm{L}$ at many sites to $149 \mu \mathrm{g} / \mathrm{L}$ at Powder River near Locate (fig. 16, table 15). Median concentrations ranged from $<1 \mu \mathrm{g} / \mathrm{L}$ at several sites to $3.0 \mu \mathrm{g} / \mathrm{L}$ at Powder River near Locate. Total-recoverable chromium concentrations varied more in the Yellowstone River basin than in the other river basins. In general, sites in the lower Yellowstone River basin (Rosebud Creek and downstream) had more variable and somewhat higher chromium concentrations compared to upstream sites in the basin. Powder River near Locate and Rosebud Creek near Rosebud were the only sites in the statewide network to have a chromium concentration greater than $100 \mu \mathrm{g} / \mathrm{L}$.

The maximum chromium concentrations at Powder River near Locate and Rosebud Creek near Rosebud exceeded the human-health standard. Although these maximum concentrations were elevated compared to other sites in the basin (fig. 16), none of the samples collected in the Yellowstone River basin had concentrations that exceeded the general chronic aquatic-life standards for chromium.

In the Columbia River basin, total-recoverable chromium concentrations ranged from $<0.8 \mu \mathrm{g} / \mathrm{L}$ at all sites to $4.4 \mu \mathrm{g} / \mathrm{L}$ at Middle Fork Flathead River near West Glacier (fig. 16, table 15). Concentrations were consistently low compared to many of the sites in the Missouri and Yellowstone River basins. Median concentrations were $<1 \mu \mathrm{g} / \mathrm{L}$ at all sites and total-recoverable chromium concentrations in most samples were $2 \mu \mathrm{g} / \mathrm{L}$ or less. None of the samples collected in the Columbia River basin had concentrations that exceeded the human-health and general aquatic-life standards.

\section{Total-Recoverable Copper}

The statistical distribution of total-recoverable copper concentrations at network sites during water years 1999-2003 is shown in figure 17. The State of Montana human-health standard of 1,300 $\mu \mathrm{g} / \mathrm{L}$ (Montana Department of Environmental Quality, 2004) for total-recoverable copper is not shown in the figure because all concentrations were substantially less than this value. The general acute and chronic aquatic-life standards for various levels of hardness (Montana Department of Environmental Quality, 2004) are shown as a general reference to potential toxicity. During 1999-2001, samples 
TOTAL-RECOVERABLE CHROMIUM

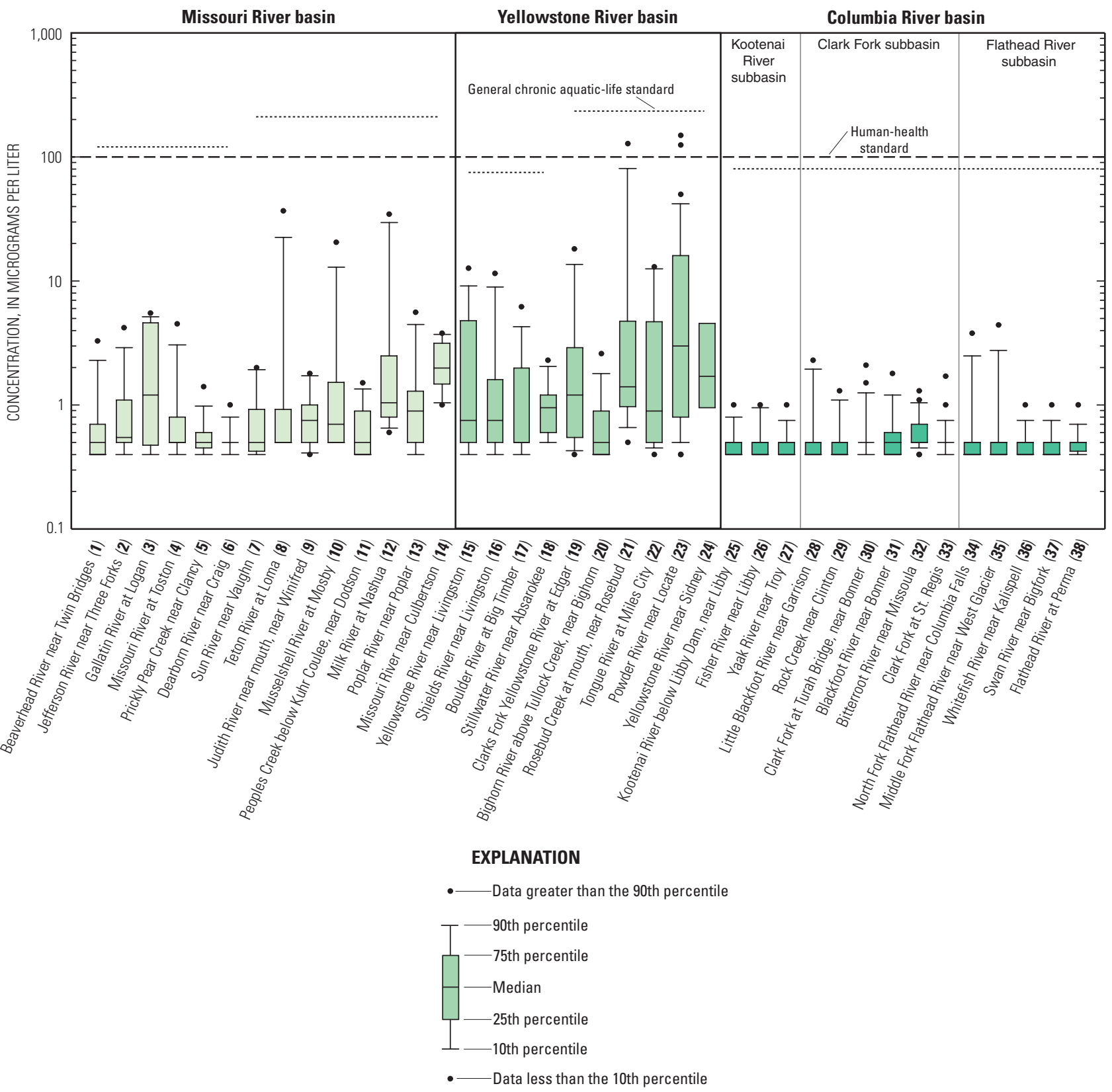

Note: When a data set contains multiple equal values, two or more of the percentile lines can overlap and result in a compressed plot

Figure 16. Statistical distribution of concentrations of total-recoverable chromium at network sites in Montana, water years 1999-2003. Site number presented after station name (fig. 1, table 1). The State of Montana human-health standard is 100 micrograms per liter. The general aquatic-life standard for chronic toxicity (table 5) was calculated using applicable equations (Montana Department of Environmental Quality, 2004) and average water hardness. Variable aquatic-life standards result from differences in the average water hardness among groups of sites. Concentrations reported as less than the laboratory reporting level are plotted as one-half the maximum laboratory reporting level. 
collected at four sites in the Columbia River basin as part of a USGS national program were analyzed with substantially higher LRLs (12-20 $\mu \mathrm{g} / \mathrm{L})$ than those used for other network sites $(0.6-1 \mu \mathrm{g} / \mathrm{L})$. Values that were censored at the higher LRLs could not be adequately adjusted to plot the statistical distribution of concentrations (fig. 17), and were deleted from the boxplot data sets. However, all data were retained for the statistical summaries presented in table 15.

Across the network, total-recoverable copper concentrations ranged from $<0.6$ to $302 \mu \mathrm{g} / \mathrm{L}$ (fig. 17 , table 15 ). Totalrecoverable copper was measured at detectable concentrations more commonly than most of the other trace elements; only about 15 percent of the samples had concentrations less than the LRL. About one-half of the sites in the network had one or more samples that exceeded either acute or chronic general aquatic-life standards for copper.

In the Missouri River basin, total-recoverable copper concentrations ranged from $<1 \mu \mathrm{g} / \mathrm{L}$ at Gallatin River at Logan, Dearborn River near Craig, and Peoples Creek near Dodson to $55.0 \mu \mathrm{g} / \mathrm{L}$ at Milk River at Nashua and commonly were less than $10 \mu \mathrm{g} / \mathrm{L}$ (fig. 17, table 15). Median concentrations ranged from $1.3 \mu \mathrm{g} / \mathrm{L}$ at Dearborn River near Craig to $5.8 \mu \mathrm{g} / \mathrm{L}$ at Missouri River near Culbertson. Copper concentrations were variable and did not show a clear spatial pattern, although median concentrations in the lower part of the basin (Teton River and downstream) generally were higher than at sites in the upper part of the basin.

The maximum concentrations at five sites (Jefferson River near Three Forks, Prickly Pear Creek near Clancy, Teton River at Loma, Musselshell River at Mosby, and Milk River at Nashua) were near or exceeded the general acute aquatic-life standards; effects of these exceedances on aquatic organisms is unknown. However, most samples had concentrations that were less than the general chronic aquatic-life standards.

In the Yellowstone River basin, total-recoverable copper concentrations ranged from $<1 \mu \mathrm{g} / \mathrm{L}$ at several sites to 302 $\mu \mathrm{g} / \mathrm{L}$ at Powder River near Locate (fig. 17, table 15); most of the concentrations were less than about $20 \mu \mathrm{g} / \mathrm{L}$. Copper concentrations showed a distinct spatial pattern with higher concentrations being more common in the lower part of the basin (Clarks Fork Yellowstone River at Edgar and downstream). Median concentrations ranged from $1.0 \mu \mathrm{g} / \mathrm{L}$ at Boulder River at Big Timber to $10.4 \mu \mathrm{g} / \mathrm{L}$ at Powder River near Locate.

Copper concentration in samples from four sites (Yellowstone River near Livingston, Shields River near Livingston, Rosebud Creek near Rosebud, and Powder River near Locate) exceeded the general acute aquatic-life standard in 10 percent or more of the samples; at Yellowstone River near Livingston and Powder River near Locate, about 25 percent of the samples were near or exceeded the general acute aquatic-life standard for copper (fig. 17). Effects of these elevated concentrations on aquatic organisms is unknown; however, a condition where copper concentrations commonly exceed general aquatic-life standards might represent a situation that poses a potential risk to biota. Copper concentrations in samples from Clarks Fork Yellowstone River at Edgar and Tongue River at
Miles City infrequently exceeded the general chronic aquaticlife standard.

In the Columbia River basin, total-recoverable copper concentrations ranged from $<0.6 \mu \mathrm{g} / \mathrm{L}$ at three sites to $117 \mu \mathrm{g} / \mathrm{L}$ at Clark Fork at Turah Bridge; most concentrations were less than $10 \mu \mathrm{g} / \mathrm{L}$ (fig. 17, table 15). Median total-recoverable copper concentrations ranged from $<1 \mu \mathrm{g} / \mathrm{L}$ at several sites to $9.0 \mu \mathrm{g} / \mathrm{L}$ at Clark Fork at Turah Bridge (after deleting values censored at high LRLs). Most median concentrations were less than about $2 \mu \mathrm{g} / \mathrm{L}$. One notable exception was Clark Fork at Turah Bridge, where elevated copper concentrations from historical mining wastes previously have been documented (Lambing, 1991; Hornberger and others, 1997; Lambing, 1998).

Copper concentrations in samples from 8 of the 14 sites occasionally exceeded either the general acute or chronic aquatic-life standards (fig. 17). At Clark Fork at Turah Bridge, more than 25 percent of the samples had concentrations that exceeded the general acute aquatic-life standard and about 50 percent of the samples had concentrations greater than the general chronic aquatic-life standard. Effects of the elevated copper concentrations on aquatic organisms at this site are unknown; however, concentrations commonly in excess of the general aquatic-life standards at Clark Fork at Turah Bridge might represent a situation that poses a potential risk to biota.

\section{Total-Recoverable Lead}

The statistical distribution of total-recoverable lead concentrations at network sites during water years 1999-2003 is shown in figure 18. The State of Montana human-health standard of $15 \mu \mathrm{g} / \mathrm{L}$, as well as the general chronic aquatic-life standards for various levels of hardness (Montana Department of Environmental Quality, 2004), are shown in the figure as a general reference to potential toxicity. General acute aquaticlife standards are not shown because all concentrations were considerably less than the standards. During the monitoring period, LRLs for lead varied substantially (table 2). However, plotting one-half of the various LRLs did not affect comparisons to the general aquatic-life standards; thus, all values were used in the boxplot data sets.

Across the network, total-recoverable lead concentrations ranged from $<0.06$ to $255 \mu \mathrm{g} / \mathrm{L}$ (table 15). With the exception of generally higher concentrations at sites in the lower Yellowstone River basin, no spatial patterns are evident for lead. In general, total-recoverable lead concentrations commonly were less than $10 \mu \mathrm{g} / \mathrm{L}$, and all median concentrations in the statewide network were $5 \mu \mathrm{g} / \mathrm{L}$ or less. However, one or more sites in every basin had at least one sample with concentrations that exceeded the human-health standard for lead. Also, about one-half of the sites had one or more samples that exceeded general chronic aquatic-life standards.

In the Missouri River basin, total-recoverable lead concentrations ranged from $<0.06 \mu \mathrm{g} / \mathrm{L}$ at Judith River near Winifred to $54 \mu \mathrm{g} / \mathrm{L}$ at Prickly Pear Creek near Clancy; concentrations typically were less than $10 \mu \mathrm{g} / \mathrm{L}$ and more than 
TOTAL-RECOVERABLE COPPER

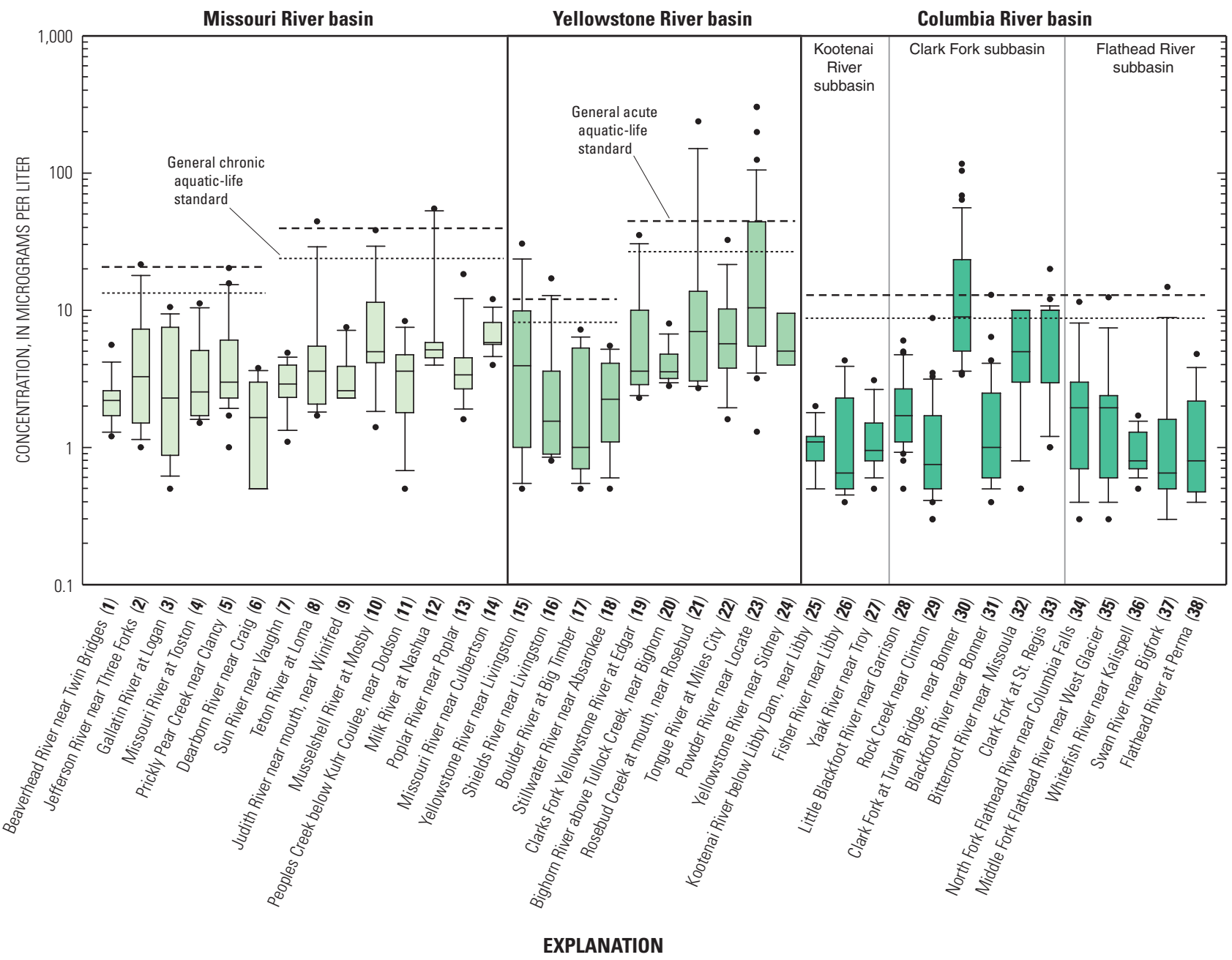

- Data greater than the 90th percentile

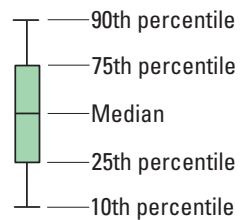

- Data less than the 10th percentile

Note: When a data set contains multiple equal values, two or more of the percentile lines can overlap and result in a compressed plot

Figure 17. Statistical distribution of concentrations of total-recoverable copper at network sites in Montana, water years 1999-2003. Site number presented after station name (fig. 1, table 1). The general aquatic-life standards for acute and chronic toxicity (table 5) were calculated using applicable equations (Montana Department of Environmental Quality, 2004) and average water hardness. Variable aquatic-life standards result from differences in the average water hardness among groups of sites. Copper values with a high laboratory reporting level of 12-20 micrograms per liter during 1999-2001 at four sites were not used to calculate statistics for this figure. Concentrations reported as less than lower laboratory reporting levels are plotted as onehalf the maximum laboratory reporting level. 
50 percent of the samples had concentrations less than $1 \mu \mathrm{g} / \mathrm{L}$ (fig. 18, table 15). Median concentrations ranged from $<1 \mu \mathrm{g} / \mathrm{L}$ at several sites to $4.9 \mu \mathrm{g} / \mathrm{L}$ at Prickly Pear Creek near Clancy. Total-recoverable lead concentrations at Prickly Pear Creek were more frequently greater than $10 \mu \mathrm{g} / \mathrm{L}$ than at other sites in the basin. Prickly Pear Creek drains a mineralized area that was mined historically and mine wastes are extensive throughout the basin (Klein and others, 2003).

Samples from several sites in the Missouri River basin exceeded the human-health standard and general chronic aquatic-life standards for lead. The human-health standard $(15 \mu \mathrm{g} / \mathrm{L})$ was exceeded in nearly 25 percent of the samples from Prickly Pear Creek near Clancy and in more than 10 percent of the samples at three other sites (Teton River at Loma, Musselshell River at Mosby, and Milk River at Nashua). General chronic aquatic-life standards were infrequently equaled or exceeded at six sites (Jefferson River near Three Forks, Gallatin River at Logan, Missouri River at Toston, Teton River at Loma, Musselshell River at Mosby, and Milk River at Nashua). However, about 50 percent of the samples from Prickly Pear Creek exceeded the general chronic aquaticlife standard for lead, which might indicate a potential risk to aquatic biota.

In the Yellowstone River basin, total-recoverable lead concentrations ranged from $<0.06 \mu \mathrm{g} / \mathrm{L}$ at Boulder River near Big Timber to $255 \mu \mathrm{g} / \mathrm{L}$ at Rosebud Creek near Rosebud; concentrations typically were less than $10 \mu \mathrm{g} / \mathrm{L}$ (fig. 18, table 15). Median concentrations ranged from $<1 \mu \mathrm{g} / \mathrm{L}$ at several sites to $5 \mu \mathrm{g} / \mathrm{L}$ at Yellowstone River near Sidney. In general, concentrations of lead at sites in the lower part of the basin (Rosebud Creek near Rosebud and downstream) were higher than at sites in the upper part of the basin. Compared to the other sites in the basin, lead concentrations varied over a wider range at Powder River near Locate, possibly due to the wide range of suspended-sediment concentrations typical of this site (fig. 11).

Several samples from three lower-basin sites (Rosebud Creek near Rosebud, Tongue River at Miles City, and Powder River near Locate) exceeded the human-health standard of $15 \mu \mathrm{g} / \mathrm{L}$ for lead in about 10 to more than 25 percent of the samples. Samples from these same three sites and two sites in the upper basin (Yellowstone River near Livingston and Shields River near Livingston) exceeded the general chronic aquatic-life standard. More than 25 percent of the samples collected from Powder River near Locate had concentrations greater than both the human-health standard and the chronic aquatic-life standard for lead. More than 25 percent of the samples collected from Yellowstone River near Livingston also exceeded the general chronic aquatic-life standard for lead, which was similar to the frequency of exceedances noted for copper at this site.

In the Columbia River basin, total-recoverable lead concentrations ranged from $<0.06 \mu \mathrm{g} / \mathrm{L}$ at Rock Creek near Clinton and Blackfoot River near Bonner to $30 \mu \mathrm{g} / \mathrm{L}$ at Clark Fork at Turah Bridge; concentrations typically were less than $5 \mu \mathrm{g} / \mathrm{L}$, with more than 70 percent of the samples having concentrations less than $1 \mu \mathrm{g} / \mathrm{L}$ (fig. 18, table 15). Almost all of the median concentrations were $<1 \mu \mathrm{g} / \mathrm{L}$. The elevated lead concentrations at Clark Fork at Turah Bridge, which had the highest median concentration $(1 \mu \mathrm{g} / \mathrm{L})$ and the highest maximum concentration $(30 \mu \mathrm{g} / \mathrm{L})$ of lead in the basin, are likely due to sediment derived from metal-rich mine wastes in the basin (Lambing, 1991; Hornberger and others, 1997; Lambing, 1998).

Three samples equaled or exceeded the human-health standard for lead at Clark Fork at Turah Bridge. Although lead concentrations at most sites commonly were low, the general chronic aquatic-life standard for lead was exceeded in at least one sample at 8 of the 14 sites in the basin. The sporadic exceedances of the standard in samples from seven of the eight sites may be partly due to the low hardness of the water at most sites in the Columbia River basin and the resulting low general chronic aquatic-life standard. The general chronic aquatic-life standard for lead was exceeded in more than 25 percent of the samples from Clark Fork at Turah Bridge, which indicates a persistent source of lead that could pose a potential risk to aquatic biota.

\section{Total-Recoverable Nickel}

The statistical distribution of total-recoverable nickel concentrations at network sites during water years 1999-2003 is shown in figure 19. The State of Montana human-health standard of $100 \mu \mathrm{g} / \mathrm{L}$, as well as the general chronic aquatic-life standards for various levels of hardness (Montana Department of Environmental Quality, 2004), are shown in the figure as a general reference to potential toxicity. General acute aquaticlife standards are not shown because all concentrations were less than the standards.

Across the network, total-recoverable nickel concentrations ranged from $<1$ to $349 \mu \mathrm{g} / \mathrm{L}$ (table 15). Distinct spatial patterns of increasing nickel concentrations in the lower parts of the Missouri and Yellowstone River basins are evident, with several samples at two sites exceeding human-health and general chronic aquatic-life standards in the Yellowstone River basin. No spatial differences in concentration are apparent for sites in the Columbia River basin, where all nickel concentrations were less than human-health and general aquatic-life standards. As with the other trace elements, concentrations of total-recoverable nickel in many samples were less than the LRL.

In the Missouri River basin, total-recoverable nickel concentrations ranged from $<1 \mu \mathrm{g} / \mathrm{L}$ at several sites to $57 \mu \mathrm{g} / \mathrm{L}$ at Milk River at Nashua; concentrations were notably higher in the tributaries and mainstem in the lower part of the basin (Sun River near Vaughn and downstream) compared to the upper basin (fig. 19, table 15). Median nickel concentrations at upper-basin sites (Dearborn River near Craig and upstream) were $2.0 \mu \mathrm{g} / \mathrm{L}$ or less, whereas the median at sites in the lower part of the basin ranged from $3.0 \mu \mathrm{g} / \mathrm{L}$ at Sun River near Vaughn to about $7 \mu \mathrm{g} / \mathrm{L}$ at both Musselshell River at Mosby and Missouri River near Culbertson. Despite the pattern of 
TOTAL-RECOVERABLE LEAD

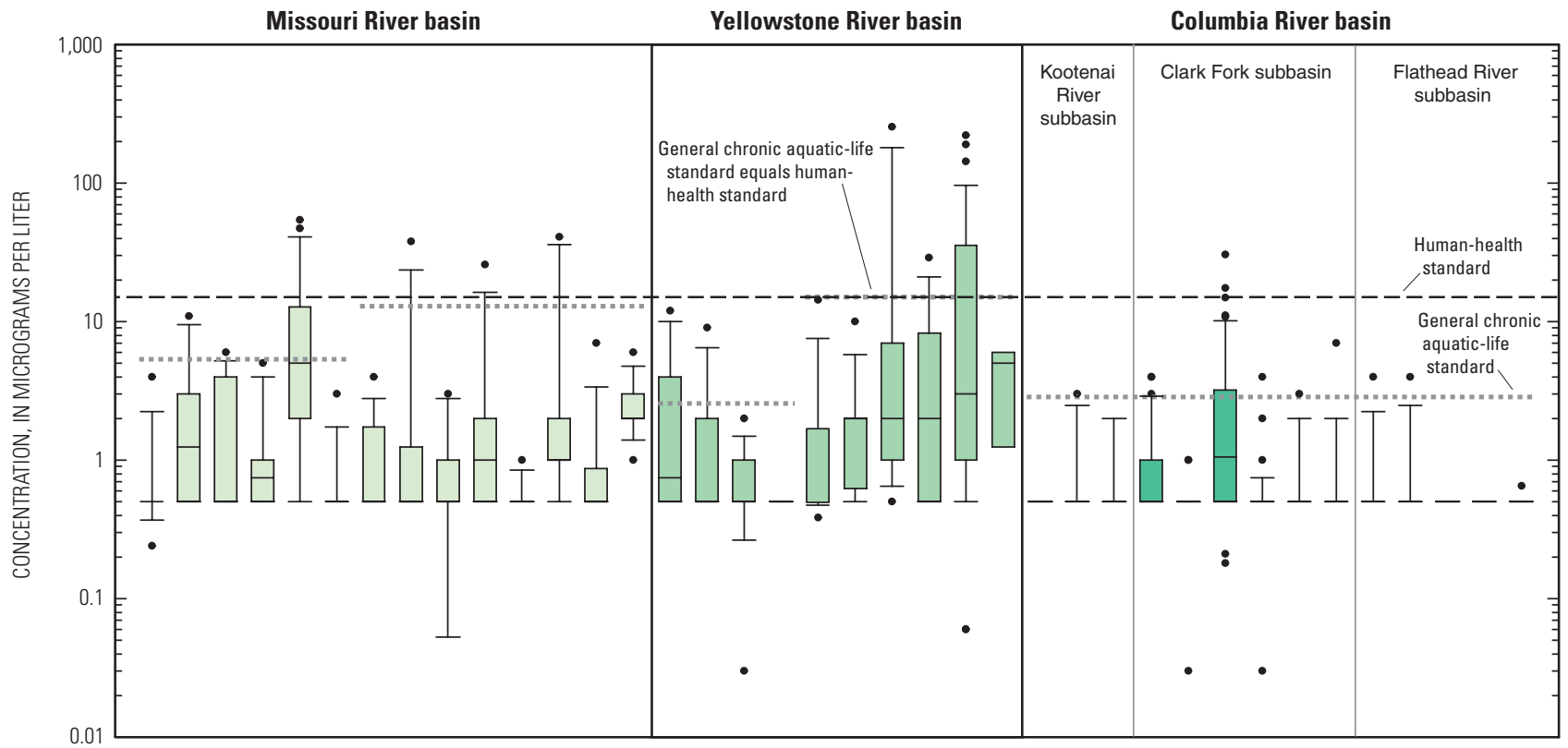

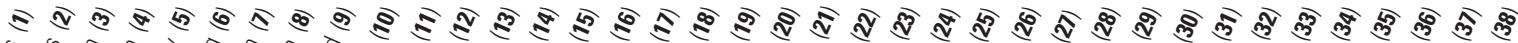

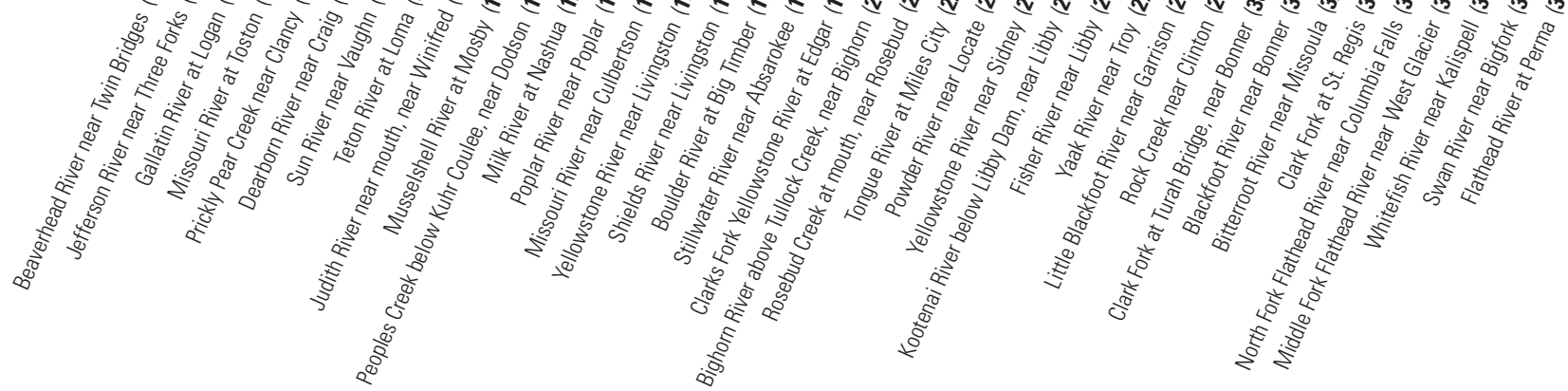

EXPLANATION

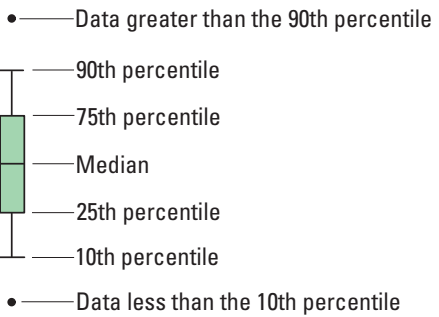

Note: When a data set contains multiple equal values, two or more of the percentile lines can overlap and result in a compressed plot

Figure 18. Statistical distribution of concentrations of total-recoverable lead at network sites in Montana, water years 19992003. Site number presented after station name (fig. 1, table 1). The State of Montana human-health standard is 15 micrograms per liter. The general aquatic-life standard for chronic toxicity (table 5) was calculated using the applicable equation (Montana Department of Environmental Quality, 2004) and average water hardness. Variable aquatic-life standards result from differences in the average water hardness among groups of sites. Concentrations reported as less than the laboratory reporting level are plotted as one-half the maximum laboratory reporting level. 
downstream increases, nickel concentrations generally were less than $10 \mu \mathrm{g} / \mathrm{L}$ in the Missouri River basin. A few samples from sites in the lower part of the basin had concentrations notably higher than $10 \mu \mathrm{g} / \mathrm{L}$, but total-recoverable nickel concentrations at all sites in the Missouri River basin were less than either the human-health or general chronic aquatic-life standards.

In the Yellowstone River basin, total-recoverable nickel concentrations ranged from $<1 \mu \mathrm{g} / \mathrm{L}$ at several sites to $349 \mu \mathrm{g} / \mathrm{L}$ at Powder River near Locate; concentrations were higher at sites in the lower part of the basin (Clarks Fork Yellowstone River at Edgar and downstream) compared to the upper basin (fig. 19, table 15). Median concentrations of totalrecoverable nickel were less than $2 \mu \mathrm{g} / \mathrm{L}$ at all of the upperbasin sites; at tributary and mainstem sites in the lower part of the basin, median concentrations ranged from 2.4 to $9.6 \mu \mathrm{g} / \mathrm{L}$. More than 10 percent of the samples from Rosebud Creek near Rosebud and Powder River near Locate exceeded the humanhealth standard of $100 \mu \mathrm{g} / \mathrm{L}$. Several samples from Rosebud Creek near Rosebud and Powder River near Locate had total-recoverable nickel concentrations greater than $200 \mu \mathrm{g} / \mathrm{L}$, which exceeded the general chronic aquatic-life standard.

In the Columbia River basin, total-recoverable nickel concentrations ranged from $<1 \mu \mathrm{g} / \mathrm{L}$ at all sites to $10.3 \mu \mathrm{g} / \mathrm{L}$ at Clark Fork at Turah Bridge; concentrations were consistently low at all sites relative to most sites in the Missouri and Yellowstone River basins (fig. 19, table 15). Median concentrations were less than $2 \mu \mathrm{g} / \mathrm{L}$ at all sites; no spatial patterns were evident. All total-recoverable nickel concentrations were considerably less than both the human-health and general chronic aquatic-life standards.

\section{Total-Recoverable Zinc}

The statistical distribution of total-recoverable zinc concentrations at network sites during water years 1999-2003 is shown in figure 20. The State of Montana human-health standard of 2,000 $\mu \mathrm{g} / \mathrm{L}$ and general aquatic-life standards for various levels of hardness (Montana Department of Environmental Quality, 2004) are shown in the figure as general references to potential toxicity. For zinc, the acute and chronic aquatic-life standards are equal. Similar to copper, a wide range of LRLs were used during the monitoring period (table 2). During the first 2 years of the monitoring period (1999 and 2000), the LRLs for zinc were 40 and $31 \mu \mathrm{g} / \mathrm{L}$, respectively. After a much lower LRL (1 $\mu \mathrm{g} / \mathrm{L})$ was available (2001-03), results of analyses showed that many stream samples had concentrations near or less than the lower censoring level. Using one-half of the LRLs from 1999-2000 (15-20 $\mu \mathrm{g} / \mathrm{L})$ would artificially introduce much higher concentrations into the boxplot data sets than were likely to have actually occurred. Consequently, because the data censored at the higher LRLs could not be adequately adjusted to plot the statistical distribution of concentrations, the censored values were deleted from the boxplot data sets. However, all data were retained for the statistical summaries presented in table 15 .
Across the network, total-recoverable zinc concentrations ranged from $<1$ to $1,110 \mu \mathrm{g} / \mathrm{L}$ (fig. 20 , table 15 ). In general, zinc concentrations varied widely among the sites, with some sites having a small range of values, while other sites exhibited a wide range of values. Similar to lead, the only apparent spatial pattern is that higher zinc concentrations generally occurred at sites in the lower part of the Yellowstone River basin (Clarks Fork Yellowstone River at Edgar and downstream) compared to sites in the upper basin. The general aquatic-life standards for zinc were exceeded infrequently across the network.

In the Missouri River basin, total-recoverable zinc concentrations ranged from $<1 \mu \mathrm{g} / \mathrm{L}$ at Dearborn River near Craig to $216 \mu \mathrm{g} / \mathrm{L}$ at Prickly Pear Creek near Clancy (fig. 20, table 15); concentrations did not indicate any clear spatial pattern. Median concentrations ranged from $1 \mu \mathrm{g} / \mathrm{L}$ at Beaverhead River near Twin Bridges and Dearborn River near Craig to $78 \mu \mathrm{g} / \mathrm{L}$ at Prickly Pear Creek near Clancy; medians at most sites were less than $5 \mu \mathrm{g} / \mathrm{L}$. The human-health standard of $2,000 \mu \mathrm{g} / \mathrm{L}$ for zinc was not exceeded in any samples. The general aquatic-life standards for zinc were exceeded occasionally in samples from one site (Prickly Pear Creek near Clancy). As with other trace elements, these elevated zinc concentrations in Prickly Pear Creek are likely due to metal-rich wastes from upstream areas where historical mining occurred (Klein and others, 2003). Three sites in the lower basin (Teton River at Loma, Musselshell River at Mosby, and Milk River at Nashua) had one or more samples with concentrations greater than $100 \mu \mathrm{g} / \mathrm{L}$, but the general aquatic-life standards were not exceeded.

In the Yellowstone River basin, total-recoverable zinc concentrations ranged from $<1 \mu \mathrm{g} / \mathrm{L}$ at several sites to $1,110 \mu \mathrm{g} / \mathrm{L}$ at Powder River near Locate (fig. 20, table 15); concentrations generally were higher in the lower part of the basin (Clarks Fork Yellowstone River and downstream). Median concentrations of zinc in the Yellowstone River basin ranged from $2 \mu \mathrm{g} / \mathrm{L}$ at Stillwater River near Absarokee to $26 \mu \mathrm{g} / \mathrm{L}$ (after deleting values censored at high LRLs) at Powder River near Locate. The human-health standard of $2,000 \mu \mathrm{g} / \mathrm{L}$ for zinc was not exceeded in any samples. About 10 percent or more of the samples from Rosebud Creek near Rosebud and Powder River near Locate had concentrations that exceeded the general aquatic-life standards for zinc.

In the Columbia River basin, total-recoverable zinc concentrations ranged from $<1 \mu \mathrm{g} / \mathrm{L}$ at many sites to $236 \mu \mathrm{g} / \mathrm{L}$ at Clark Fork at Turah Bridge (fig. 20, table 15). Zinc concentrations in the Columbia River basin generally were lower than in the Missouri and Yellowstone River basins, with many samples having concentrations less than the LRL. Clark Fork at Turah Bridge had notably higher zinc concentrations compared to the other sites in the Columbia River basin. Median concentrations of total-recoverable zinc ranged from $1 \mu \mathrm{g} / \mathrm{L}$ at several sites to $18 \mu \mathrm{g} / \mathrm{L}$ (after deleting censored values with high LRLs) at Clark Fork at Turah Bridge. The human-health standard of 2,000 $\mu \mathrm{g} / \mathrm{L}$ for zinc was not exceeded in any 
TOTAL-RECOVERABLE NICKEL

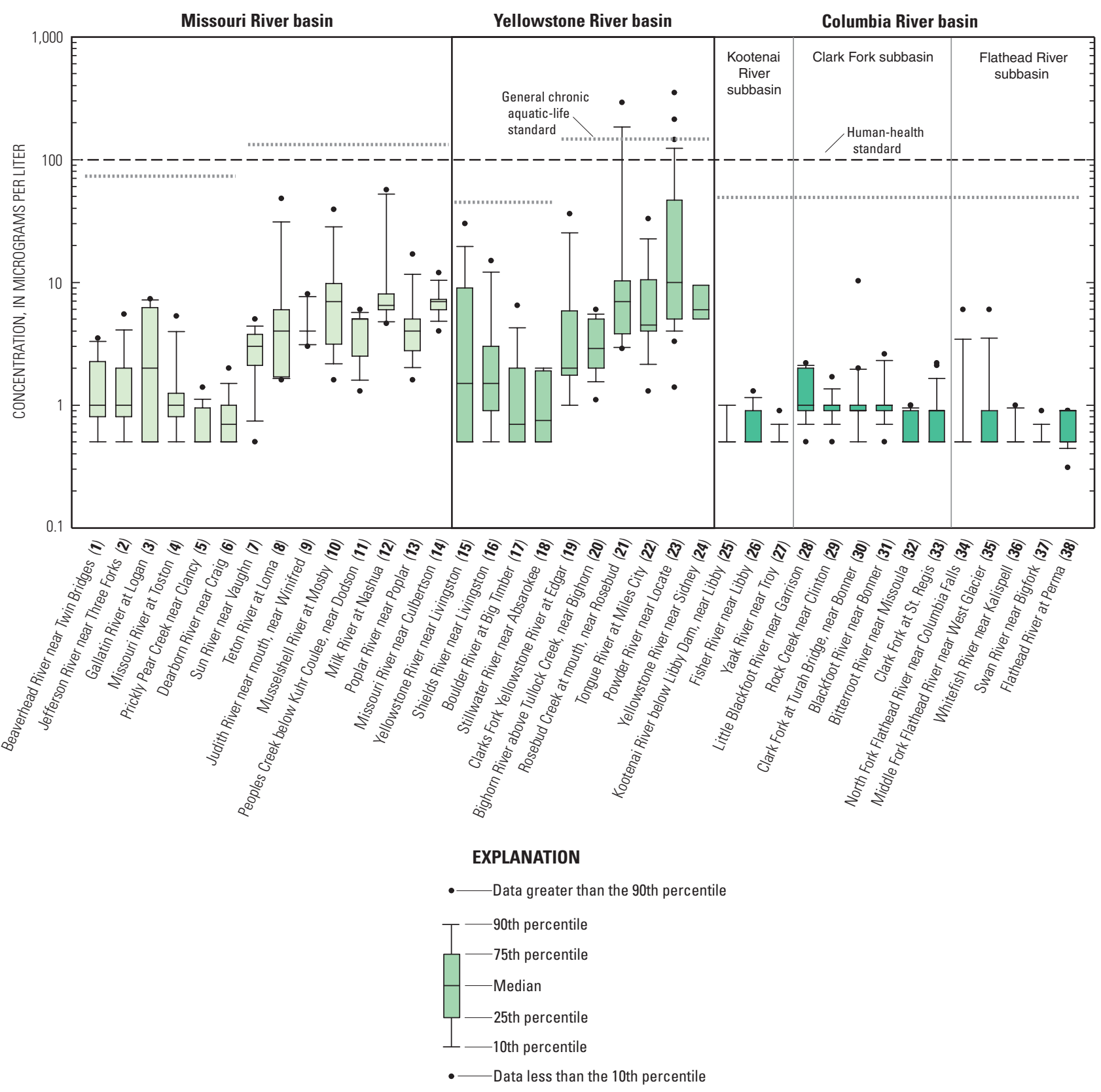

Note: When a data set contains multiple equal values, two or more of the percentile lines can overlap and result in a compressed plot

Figure 19. Statistical distribution of concentrations of total-recoverable nickel at network sites in Montana, water years 19992003. Site number presented after station name (fig. 1, table 1). The State of Montana human-health standard is 100 micrograms per liter. The general aquatic-life standard for chronic toxicity (table 5) was calculated using the applicable equation (Montana Department of Environmental Quality, 2004) and average water hardness. Variable aquatic-life standards result from differences in the average water hardness among groups of sites. Concentrations reported as less than the laboratory reporting level are plotted as one-half the maximum laboratory reporting level. 
TOTAL-RECOVERABLE ZINC

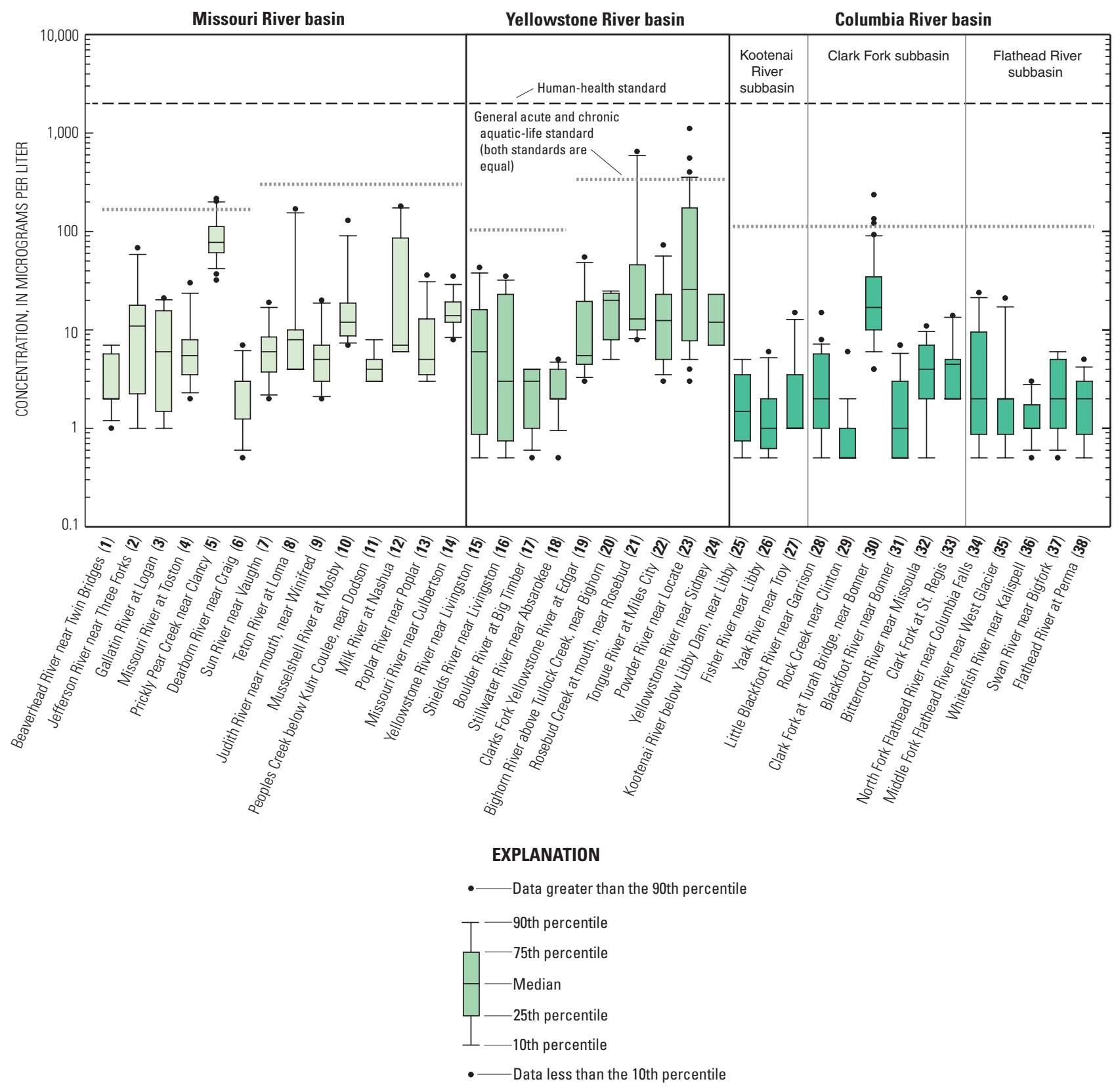

Note: When a data set contains multiple equal values, two or more of the percentile lines can overlap and result in a compressed plot

Figure 20. Statistical distribution of concentrations of total-recoverable zinc at network sites in Montana, water years 1999-2003. Site number presented after station name (fig. 1, table 1). The State of Montana human-health standard is 2,000 micrograms per liter. The general aquatic-life standards for acute and chronic toxicity (table 5) were calculated using applicable equations (Montana Department of Environmental Quality, 2004) and average water hardness. Variable aquatic-life standards result from differences in the average water hardness among groups of sites. Zinc values with a high laboratory reporting level of 31-40 micrograms per liter during 1999-2000 at 33 sites were not used to calculate statistics for this figure. Concentrations reported as less than lower laboratory reporting levels are plotted as one-half the maximum laboratory reporting level. 
samples. The general aquatic-life standards for zinc were exceeded occasionally only at Clark Fork at Turah Bridge.

\section{Estimated Annual Loads}

An additional objective of the statewide monitoring program was to examine the data obtained during water years 1999-2003 for adequacy in estimating annual constituent loads. Loads represent the mass of a constituent that is discharged past a point in the basin (the sampling site) during a specified period of time. Loads can be computed for instantaneous, daily, or annual time increments. However, estimates of annual loads are more informative than instantaneous loads measured at the time of sampling because annual loads are useful for comparisons of sustained constituent transport among sites. Therefore, loads in this report were estimated on an annual basis and descriptions of the relative differences in loads among sites are primarily based on the mean of estimated annual loads for the 5-year monitoring period. The range of estimated annual loads at each site during the 5-year period also is presented to demonstrate the degree of variability in annual loads that can result from varying hydrologic conditions.

The benefit of having an estimate of annual loads transported past a network of sites in a basin is to identify what parts of the watershed are contributing the largest quantities of a constituent to the receiving streams. An example of such a network assessment is the description of constituent loads transported out of tributary basins and discharged to the mainstem of the major river, which can reveal the magnitude of loads from individual tributaries relative to the total load at the downstream end of the mainstem. An accounting of load inputs can identify source areas in a watershed that are delivering disproportionate amounts of constituents relative to other source areas or relative to the streamflow contributed from the source area. This type of assessment cannot be determined solely by concentration data. If the network of sites is sufficient to provide detailed spatial resolution, specific parts of the basin contributing excessive quantities of constituent can be identified. Resource-management agencies can use this information to more effectively evaluate conditions, investigate possible localized sources of large loads, consider management actions that might decrease loads, and establish priorities for addressing particular areas within the basin.

In many instances, the quantity of streamflow is the major factor that determines the mass of a constituent transported, especially when constituent concentrations are low or relatively constant. Because streamflows can vary greatly between sites and from day to day at the same site, the mass load of constituents discharged over time from each source area may be as much a function of streamflow characteristics as it is of water-quality characteristics. In many basins, most of a stream's annual constituent load can be transported during the relatively short period of high flow (fig. 2). Consequently, annual load estimates provide an additional perspective from which to evaluate the relative influence of an inflow on the water quality in the receiving stream. Although beyond the scope of this report, detailed information on constituent loads and streamflow can be incorporated into mixing models, whereby the combined quantities of water and constituent from multiple inputs can be used to estimate the resulting concentration in the receiving stream.

Annual loads can be estimated if a statistically significant relation exists between the constituent that is to be estimated and a hydrologically related characteristic that is frequently measured. Streamflow commonly is used as the explanatory variable in constituent-discharge relations because of the generally strong association with water quality. Also, the continuous streamflow records from streamflow-gaging stations at the sampling sites provide a daily measure of variation in the explanatory variable that can be used to estimate a time series of daily constituent loads. In some cases, daily loads can be estimated without a relation if constituent concentrations are generally constant throughout the range of streamflow. Other variables, such as concentrations of suspended sediment or other constituents, may provide stronger relations with the constituent to be estimated but they are either typically not measured on a frequent basis or their use requires a multi-step computational process that is only warranted when sufficient data exist to characterize a wide range of conditions. Ideally, an adequate number of samples would be available by which to characterize a broad range of hydrologic and water-quality conditions, both within years and between years. In addition, sufficient seasonal data are needed to account for possible effects of variable land-use practices on the delivery of constituents to the streams.

As a result of the low sampling frequency used in the statewide monitoring program, especially for constituents sampled only two times per year, the amount of data at most sites is considered only marginally adequate to provide gross estimates of annual load. Some constituents do not have adequate data to make load estimates due to the excessive number of analytical results having censored concentrations less than the LRL. Therefore, this effort represents an exploratory tool to provide, where possible, generalized estimates of annual loads. Because the annual loads estimated in this report represent only gross approximations due to modest sample size, the primary use of these data is to illustrate relative differences among sites, rather than to represent quantitative measures of loads. In addition, because of the prevalence of below-normal streamflow at many of the sites during the monitoring period, annual loads estimated for 1999-2003 are assumed to be smaller than long-term mean annual loads.

Relative assessments of annual loads can be made by comparing loads at individual sites to the load at the downstream end of the mainstem. The load transported past each upstream sampling site can be described as a percentage of the total load at the downstream end of the mainstem to indicate the relative magnitude of load contributions from upstream source areas. The loads from individual upstream source areas also can be summed to determine if the combined load reason- 
ably matches the load at the downstream end of the mainstem (basin total load). In the absence of major sinks, such as mainstem reservoirs, the cumulative load from upstream source areas would be expected to be generally similar to the load at the downstream end of the mainstem, assuming that all of the major tributaries are sampled. A reasonably close match indicates a conservative downstream routing of loads, whereby loads are additive and do not decrease due to deposition or other processes. A combined load from upstream sources that is much greater than the load at the downstream end of the mainstem indicates non-conservative transport, presumably due to loss of constituent by deposition or other processes. A combined load from upstream sources that is much less than the load at the downstream end of the mainstem indicates that additional, unmeasured sources are contributing substantial quantities of constituent to the mainstem. Because all loads are subject to estimation error, minor differences in loads between sites are assumed to be negligible for purposes of relative comparison.

An additional assessment of relative inputs can be made by comparing the proportionality of load and streamflow. Sites that contribute a large percentage of the basin's total load, but only a small percentage of the total streamflow, can be assumed to have elevated concentrations relative to other sites where load and streamflow percentages are similar. Although disproportionate contributions of load and streamflow can result from natural conditions that reflect precipitation, geology, or soils characteristics, they may also indicate the effects of land use. Such cause-and-effect assessments are beyond the scope of this report.

In the Missouri River basin, major sources of load not accounted for by the sampling network include large tributaries such as the Smith and Marias Rivers (fig. 1). In addition, several large reservoirs on the Missouri River mainstem (Canyon Ferry, Hauser, Holter, and Fort Peck) presumably trap a large percentage of the incoming load, especially for constituents that are adsorbed to sediment derived from the upstream part of the basin. Because 63 percent of the drainage area at Missouri River near Culbertson is upstream from Fort Peck Reservoir (U.S. Geological Survey, issued annually), a large portion of the loads transported from the upper basin may be deposited either in this reservoir or other upstream reservoirs on the mainstem. Therefore, a substantial portion of constituent load passing the Missouri River near Culbertson that is not accounted for by the combined loads from the Milk and Poplar Rivers (which enter the mainstem downstream from Fort Peck Reservoir) may be derived from unmeasured sources downstream from Fort Peck Reservoir, such as tributaries and channel erosion. The load contributed by these unmeasured sources cannot be quantified, however, because the load passing through Fort Peck Reservoir is unknown.

All of the major tributaries in the Yellowstone River basin were sampled for this program; thus, combined loads from network sites presumably account for most of the major sources of constituent load contributed to the Yellowstone River mainstem. Also, the absence of reservoirs on the main- stem where loads could be deposited enables a fairly straightforward assessment of load contributions as a percentage of the mean annual load passing the Yellowstone River near Sidney.

Unlike the Missouri and Yellowstone River basins, the Columbia River basin does not have a single mainstem station that represents the total load transported from the entire Montana portion of the Columbia River basin. A partial assessment of load percentages can be done for the Clark Fork subbasin by using the Clark Fork at St. Regis as the downstream index site. The Flathead River enters the Clark Fork downstream from this site (fig. 1) so the contribution from this subbasin is not included in the loads estimated for the Clark Fork at St. Regis. However, the combined loads of the Clark Fork at St. Regis plus Flathead River at Perma can be used as a more comprehensive downstream index of total load for the Clark Fork and Flathead River subbasins for assessing relative contributions from upstream source areas. The Kootenai River subbasin does not have an equivalent downstream index station for total basin load. Thus, the loads in the Kootenai River subbasin are only generally described.

Annual loads can vary substantially between years, depending on the prevailing hydrologic conditions (such as drought or floods). This large degree of annual variation can have implications for the ability of short-term monitoring programs to adequately characterize the full range of constituent transport from source areas. The 5-year mean of the estimated annual loads for water years 1999-2003 provides the most representative measure available from the statewide monitoring program to compare transport characteristics for a common time period among all the network sites. Mean annual loads are the primary basis for comparisons among sites; however, it is useful to understand the degree to which annual loads can vary in order to recognize that the load transported in any individual year may not adequately characterize long-term average conditions. To illustrate the variability during the 5-year monitoring period, the range in estimated annual loads is presented to indicate the dynamic response of streams to either the supply of constituents in source areas or to the magnitude of runoff available to transport the constituent supply.

\section{Computational Methods for Estimating Annual Loads}

Regression analysis was used to examine the relation between constituent discharge and instantaneous streamflow for the 38 sites in the statewide monitoring program. Where possible, an ordinary least squares regression analysis was used to develop equations to estimate constituent loads. Streamflow was used as the explanatory variable because it was continuously determined at all sites and thereby could provide a quantitative measure of daily variations in hydrologic conditions.

Regression analysis generally was not used when the number of samples with uncensored values was less than eight 
because of the restricted range of data available to describe the response in constituent discharge to changes in streamflow. Additional uncertainty is imposed when the LRLs changed substantially during the monitoring period and adjustments to the censored data, such as substitution with a value of one-half the LRL, result in adjusted values of different magnitude. In these instances, an assessment was made on a case-by-case basis to determine whether to forego developing a relation by regression analysis, restrict the portion of the data used by analyzing only recent data with lower LRLs, substitute censored values with one-half of the LRL, or use an alternate method of load estimation.

Prior to developing the regression equations, instantaneous constituent discharge was determined from constituent concentrations and instantaneous streamflow for each of the samples and then converted to a constituent discharge, in tons per day, according to the following equation:

$$
Q \operatorname{con}=C Q K
$$

where

Qcon is the constituent discharge, in tons per day; $C \quad$ is the constituent concentration, in milligrams or micrograms per liter;

$Q \quad$ is the streamflow, in cubic feet per second; and

$K \quad$ is the units conversion constant (0.0027 if concentration is in milligrams per liter or 0.0000027 if concentration is in micrograms per liter).

After constituent concentrations were converted to constituent discharge, regression relations were developed between constituent discharge and streamflow. The resulting equations were applied to daily mean streamflow values obtained from gage records to compute estimated daily loads, in tons. The estimated daily loads for each water year were summed to determine an annual load. These estimated annual loads (for the 5-year period of water years 1999-2003) were then averaged to determine the mean of the estimated annual loads (referred to as mean annual load in subsequent sections).

Various forms of data transformation were examined to determine the best fit of the data to a linear regression line. Selection of the best data transformation for regression analysis was based on the ability to produce equations that were statistically significant at the 95-percent confidence level $(\mathrm{p}<0.05)$ and that had a uniform distribution of residuals about the regression line. No adjustments were made for logarithmic-transformation bias correction due to the minimal number of samples and the restriction of load interpretations to only relative comparisons among sites, rather than as quantitative estimates of loads. In addition, data were not analyzed by season because most sites had too few samples with which to partition the data and still maintain an adequate sample size for each season. Only those regression equations that were statistically significant $(\mathrm{p}<0.05)$ were used to estimate daily loads.

Sites where regression equations were developed from data sets having 25 percent or more censored concentrations, or where alternate methods of load estimation were used, are noted in subsequent sections of this report. Annual loads were estimated only for those constituents that had sufficient data to develop equations for most of the sites in one or more of the major river basins. Because of few data for some constituents, the estimated loads presented in this report are very general and intended primarily for relative comparisons between sites.

The relative accuracy of loads can be evaluated based on the regression statistics. Equations that have either a low p-value (about 0.0010 or lower) or high coefficient of determination $\left(\mathrm{R}^{2}\right)$ value (about 0.70 or higher) generally will provide more reliable load estimates than equations that have either p-values near 0.05 or low $R^{2}$ values (generally about 0.50 or less). The standard error (SE) of the regression estimate is a measure of the scatter of the data points around the regression line. The regression equations describe relations only for the range of streamflow that was sampled (table 4, table 15); therefore, extrapolation of the relation to higher streamflows might be subject to substantial error. Finally, selection of appropriate equations also was based on assessment of physical routing of loads, whereby the loads from upstream sources were assumed to be conservative and summed to a combined load that was reasonably similar to that at the downstream site on the mainstem. If the combined loads did not produce a reasonable match with the load at the downstream index station, a different form of equation was examined and used.

\section{Nutrients}

Mean annual loads were estimated for three nutrient compounds-total ammonia plus organic nitrogen, total nitrogen, and total phosphorus. Regression equations were not developed and loads were not estimated for dissolved nitrite plus nitrate or dissolved orthophosphate because these dissolved nutrient concentrations were low and many concentrations were less than the LRL. Loads for total nitrogen were determined from the estimated concentrations obtained by adding dissolved nitrite plus nitrate and total ammonia plus organic nitrogen.

\section{Total Ammonia Plus Organic Nitrogen}

Equations for estimating daily loads of total ammonia plus organic nitrogen at network sites are presented in table 6, along with the range and mean of estimated annual loads during water years 1999-2003. For all sites, the data were logarithmically transformed to produce the best fit of the data to a linear regression line. The equations for all sites in the statewide network were statistically significant (range of $\mathrm{p}$-values from $<0.0001$ to 0.0002 ). Values of $\mathrm{R}^{2}$ ranged from 0.42 to 0.98 indicating that the accuracy of estimated annual loads may vary substantially among sites. The range and mean 
of estimated annual loads of total ammonia plus organic nitrogen at network sites during water years 1999-2003 are shown in figure 21. Across the network, the means of the estimated annual loads of total ammonia plus organic nitrogen ranged from 2.73 to 5,030 tons (table 6).

Table 6. Equations for estimating daily loads of total ammonia plus organic nitrogen and summaries of the range and mean of estimated annual loads at network sites in Montana, water years 1999-2003.

[Abbreviations: $\mathrm{R}^{2}$, coefficient of determination; $\mathrm{p}$, significance level; SE, standard error, in percent; NQ, total ammonia plus organic nitrogen discharge, in tons per day; Q, daily mean streamflow, in cubic feet per second. Symbol: <, less than]

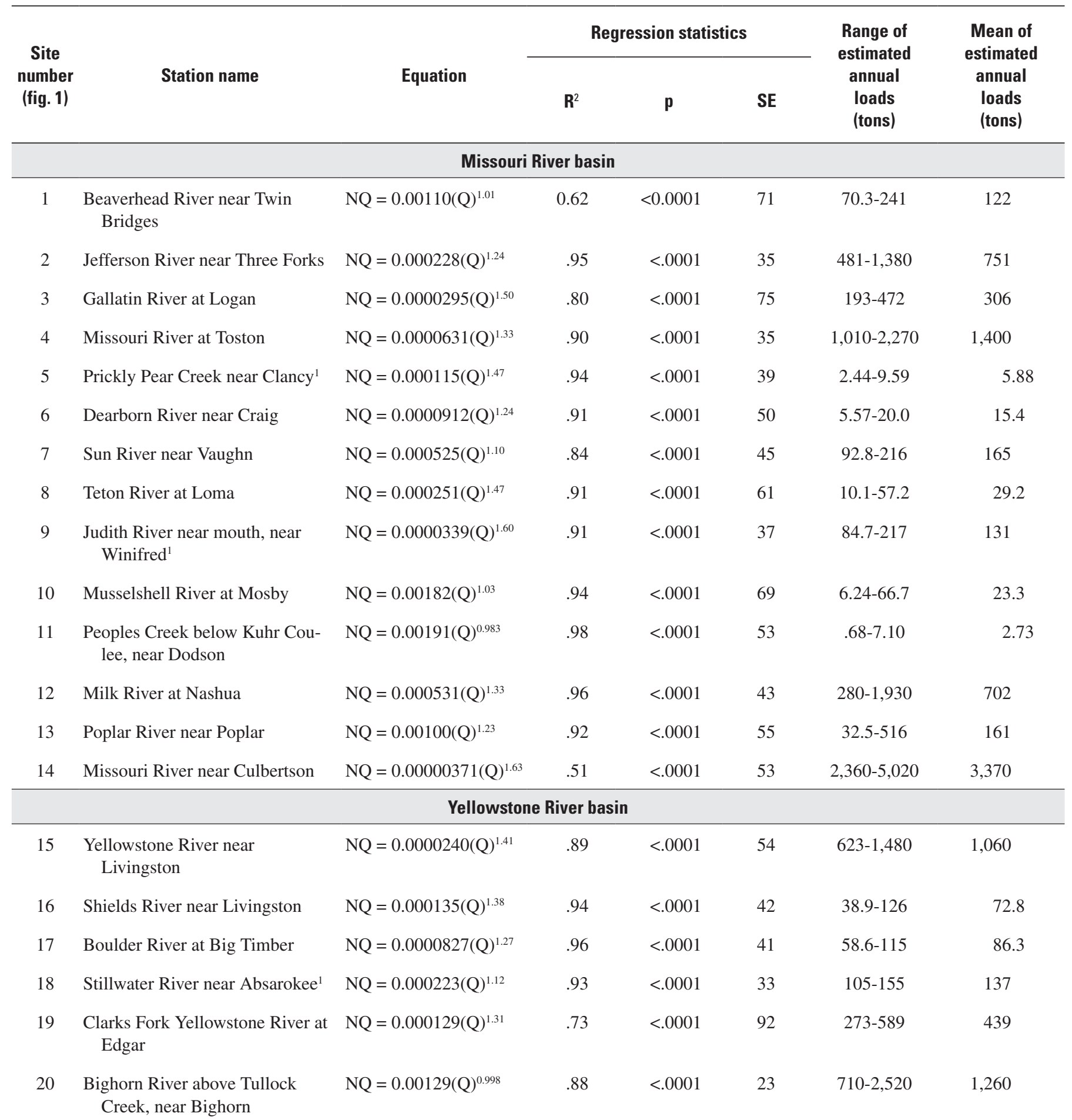


Table 6. Equations for estimating daily loads of total ammonia plus organic nitrogen and summaries of the range and mean of estimated annual loads at network sites in Montana, water years 1999-2003.—Continued

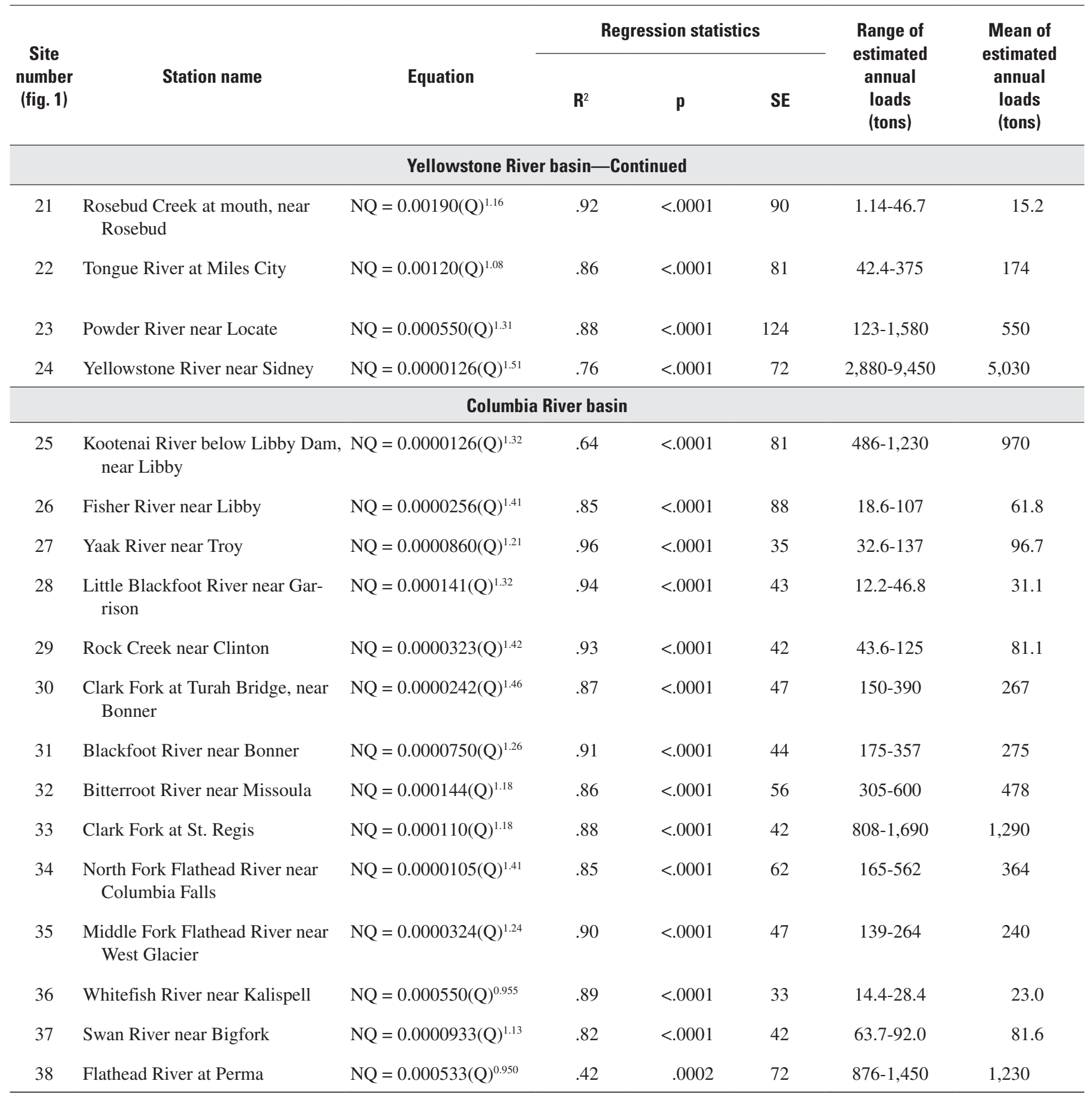

${ }^{1}$ Less than 5 years of either sample data or daily mean streamflow record were available for load calculations. 
In the Missouri River basin, mean annual loads of total ammonia plus organic nitrogen ranged from 2.73 tons at Peoples Creek near Dodson to 3,370 tons at Missouri River near Culbertson. Annual loads of total ammonia plus organic nitrogen for individual years during 1999-2003 ranged from 0.68 ton at Peoples Creek near Dodson to 5,020 tons at Missouri River near Culbertson (fig. 21, table 6). The largest variation in annual loads (ratio of the smallest annual load to the largest annual load, in percent) during the 5-year period occurred at Poplar River near Poplar, where the smallest annual load was about 6 percent of the largest load. The smallest variation in annual loads occurred at Missouri River near Culbertson, where the smallest annual load was about 47 percent of the largest load.

The combined mean annual load (2,640 tons) of total ammonia plus organic nitrogen for Missouri River at Toston plus the downstream sampled tributaries accounted for about 78 percent of the mean annual load (3,370 tons) at Missouri River near Culbertson. The combined mean annual streamflow for these sites during water years 1999-2003 (table 4) represented only about 62 percent of the mean annual streamflow at Missouri River near Culbertson; therefore, the combined

TOTAL AMMONIA PLUS ORGANIC NITROGEN

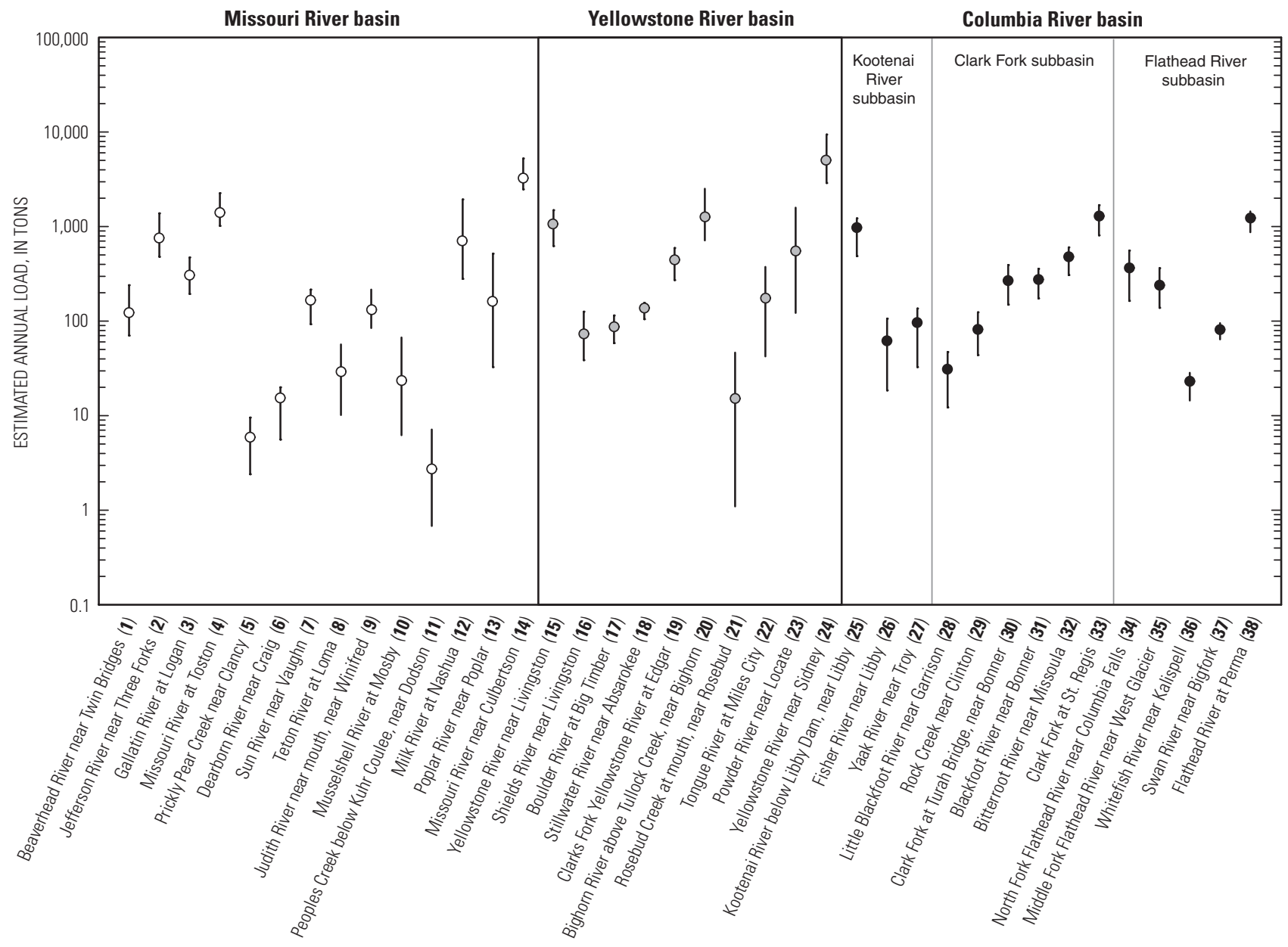

EXPLANATION

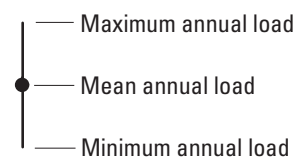

Figure 21. Range and mean of estimated annual loads of total ammonia plus organic nitrogen at network sites in Montana, water years 1999-2003. Site number presented after station name (fig. 1, table 1). 
load from upstream sources is proportionally high relative to the combined streamflow. The largest mean annual load of total ammonia plus organic nitrogen from upstream sources was transported past Missouri River at Toston (1,400 tons), which accounted for about 42 percent of the mean annual load at Missouri River near Culbertson (table 6). The load from the basin above Toston was generally proportional relative to the streamflow contribution of about 46 percent. The next largest mean-annual load from upstream sources was transported past Milk River at Nashua (702 tons), which accounted for about 21 percent of the mean annual load at Missouri River near Culbertson; the load from the Milk River was proportionally high relative to the streamflow contribution of only about 4 percent.

In the Yellowstone River basin, mean annual loads of total ammonia plus organic nitrogen ranged from 15.2 tons at Rosebud Creek near Rosebud to 5,030 tons at Yellowstone River near Sidney. Annual loads of total ammonia plus organic nitrogen for individual years during 1999-2003 ranged from 1.14 tons at Rosebud Creek near Rosebud to 9,450 tons at Yellowstone River near Sidney (fig. 21, table 6). The largest variation in annual loads occurred at Rosebud Creek near Rosebud, where the smallest annual load was about 2 percent of the largest load. The smallest variation in annual loads occurred at Stillwater River near Absarokee, where the smallest annual load was about 68 percent of the largest load.

The combined mean annual load (3,790 tons) of total ammonia plus organic nitrogen for Yellowstone River near Livingston plus downstream sampled tributaries accounted for about 75 percent of the mean annual load (5,030 tons) at Yellowstone River near Sidney (table 6). The combined mean annual streamflow for these sites during water years 1999-2003 (table 4) was within 2 percent of the flow at Yellowstone River near Sidney, thereby indicating that no major hydrologic source was unsampled. However, the proportional difference between load and streamflow contributions indicates that unmeasured sources are contributing about 25 percent of the total ammonia plus organic nitrogen load to the Yellowstone River near Sidney. The largest mean annual load of total ammonia plus organic nitrogen from upstream sources was transported past Bighorn River near Bighorn (1,260 tons), which accounted for about 25 percent of the mean annual load at Yellowstone River near Sidney (table 6). The load from the Bighorn River is proportional to the streamflow contribution of about 31 percent. The next largest mean annual load from upstream sources was transported past Yellowstone River near Livingston (1,060 tons), which accounted for about 21 percent of the mean annual load at Yellowstone River near Sidney; however, the load from this source area was small relative to the streamflow contribution of 39 percent.

In the Columbia River basin, mean annual loads of total ammonia plus organic nitrogen ranged from 23.0 tons at Whitefish River near Kalispell to 1,290 tons at Clark Fork at St. Regis. Annual loads of total ammonia plus organic nitrogen for individual years during 1999-2003 ranged from 12.2 tons at Little Blackfoot River near Garrison to 1,690 tons at Clark
Fork at St. Regis (fig. 21, table 6). Year-to-year variation in annual loads during the 5-year monitoring period generally was not as variable at sites in the Columbia River basin as in the other two major river basins. The largest variation in annual loads of total ammonia plus organic nitrogen occurred at Fisher River near Libby, where the smallest load was about 17 percent of the largest load. The smallest variation in annual loads occurred at Swan River near Bigfork, where the smallest annual load was about 69 percent of the largest annual load.

In the Kootenai River portion of the Columbia River basin, the largest mean annual load of total ammonia plus organic nitrogen (970 tons) was transported past Kootenai River below Libby Dam (table 6). The much larger load at this site compared to Yaak or Fisher Rivers is a function of the substantially greater streamflow (table 4 ) because concentrations of ammonia plus organic nitrogen were relatively low at Kootenai River below Libby Dam when compared to concentrations in samples from the Yaak and Fisher Rivers (fig. 7). In the Clark Fork and Flathead River subbasins of the Columbia River basin, similar mean annual loads of total ammonia plus organic nitrogen were transported past Clark Fork at St. Regis (1,290 tons) and Flathead River at Perma (1,230 tons) (table 6). These loads represented about 51 and 49 percent, respectively, of the combined mean annual load (2,520 tons) for Clark Fork at St. Regis plus Flathead River at Perma. The mean annual load from the Clark Fork (51 percent) was proportionally higher than the mean annual streamflow contribution of about 38 percent. The largest mean annual load of total ammonia plus organic nitrogen from sources in the Clark Fork subbasin upstream from St. Regis was transported past Bitterroot River near Missoula (478 tons), which accounted for about 37 percent of the mean annual load at Clark Fork at St. Regis (table 6). The load from the Bitterroot River was proportional to the streamflow contribution of about 33 percent. The combined mean annual load of total ammonia plus organic nitrogen (1,020 tons) for Clark Fork at Turah Bridge, Blackfoot River near Bonner, and Bitterroot River near Missoula represented about 79 percent of the mean annual load (1,290 tons) at Clark Fork at St. Regis, which is only slightly higher than the combined mean annual streamflow contribution of about 73 percent.

\section{Total Nitrogen}

Equations for estimating daily loads of total nitrogen at network sites are presented in table 7, along with the range and mean of estimated annual loads during water years 1999-2003. For all sites, the data were logarithmically transformed to produce the best linear fit of the regression line. The total nitrogen loads were calculated using regression equations that were developed from estimated sample concentrations of total nitrogen obtained by adding concentrations of dissolved nitrite plus nitrate and total ammonia plus organic nitrogen. The equations for all sites in the statewide network were statistically significant ( $\mathrm{p}$-values $<0.0001$ ). Values of $\mathrm{R}^{2}$ ranged from 0.42 to 0.98 , indicating that the accuracy of estimated annual 
loads may vary substantially among sites. The range and mean of estimated annual loads of total nitrogen at network sites during water years 1999-2003 are shown in figure 22. Across the network, the mean of the estimated annual loads of total nitrogen ranged from 2.96 to 7,220 tons (table 7). Both the magnitude and spatial pattern of variation in total nitrogen loads closely paralleled those of loads for total ammonia plus organic nitrogen, indicating that dissolved nitrite plus nitrate is a relatively small component of the total nitrogen load at most sites in the network.

Table 7. Equations for estimating daily loads of total nitrogen ${ }^{1}$ and summaries of the range and mean of estimated annual loads at network sites in Montana, water years 1999-2003.

[Abbreviations: $\mathrm{R}^{2}$, coefficient of determination; $\mathrm{p}$, significance level; SE, standard error, in percent; TNQ, total nitrogen discharge, in tons per day; Q, daily mean streamflow, in cubic feet per second. Symbol: <, less than]

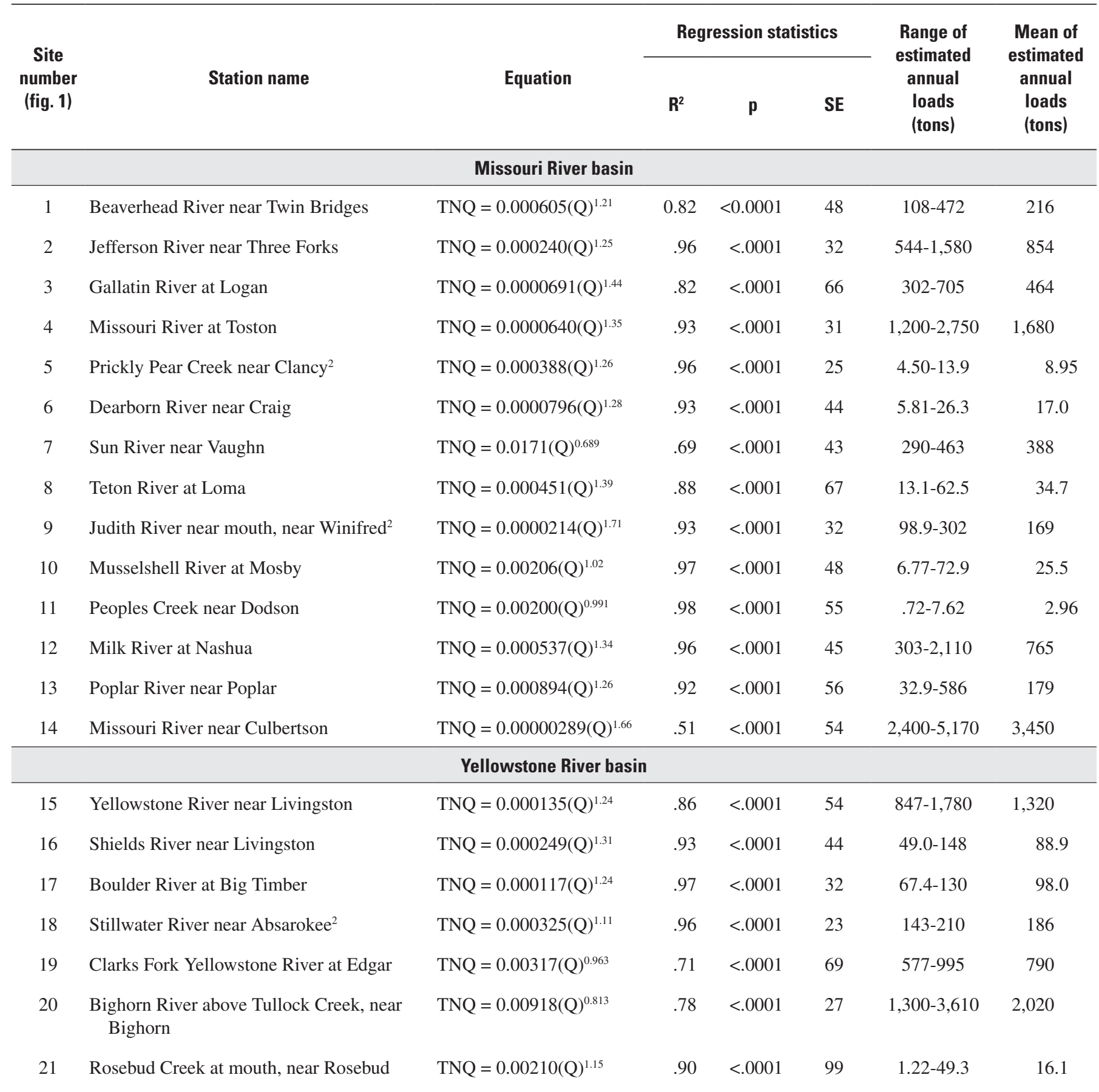


Table 7. Equations for estimating daily loads of total nitrogen ${ }^{1}$ and summaries of the range and mean of estimated annual loads at network sites in Montana, water years 1999-2003._-Continued

\begin{tabular}{|c|c|c|c|c|c|c|c|}
\hline \multirow{2}{*}{$\begin{array}{c}\text { Site } \\
\text { number } \\
\text { (fig. 1) }\end{array}$} & \multirow{2}{*}{ Station name } & \multirow{2}{*}{ Equation } & \multicolumn{3}{|c|}{ Regression statistics } & \multirow{2}{*}{$\begin{array}{c}\text { Range of } \\
\text { estimated } \\
\text { annual } \\
\text { loads } \\
\text { (tons) }\end{array}$} & \multirow{2}{*}{$\begin{array}{c}\text { Mean of } \\
\text { estimated } \\
\text { annual } \\
\text { loads } \\
\text { (tons) }\end{array}$} \\
\hline & & & $\mathbf{R}^{2}$ & $\mathbf{p}$ & SE & & \\
\hline \multicolumn{8}{|c|}{ Yellowstone River basin-Continued } \\
\hline 23 & Powder River near Locate & $\mathrm{TNQ}=0.000650(\mathrm{Q})^{1.31}$ & .90 & $<.0001$ & 105 & $159-1,870$ & 650 \\
\hline 24 & Yellowstone River near Sidney & $\mathrm{TNQ}=0.000112(\mathrm{Q})^{1.32}$ & .81 & $<.0001$ & 52 & $4,590-12,700$ & 7,220 \\
\hline \multicolumn{8}{|c|}{ Columbia River basin } \\
\hline 27 & Yaak River near Troy & $\mathrm{TNQ}=0.0000874(\mathrm{Q})^{1.22}$ & .96 & $<.0001$ & 36 & $37.8-172$ & 114 \\
\hline 28 & Little Blackfoot River near Garrison & $\mathrm{TNQ}=0.000139(\mathrm{Q})^{1.33}$ & .94 & $<.0001$ & 43 & $12.6-48.9$ & 32.4 \\
\hline 29 & Rock Creek near Clinton & $\mathrm{TNQ}=0.0000339(\mathrm{Q})^{1.42}$ & .93 & $<.0001$ & 40 & $44.5-128$ & 82.8 \\
\hline 30 & Clark Fork at Turah Bridge, near Bonner & $\mathrm{TNQ}=0.0000587(\mathrm{Q})^{1.36}$ & .90 & $<.0001$ & 39 & $185-441$ & 309 \\
\hline 31 & Blackfoot River near Bonner & $\mathrm{TNQ}=0.0000751(\mathrm{Q})^{1.27}$ & .91 & $<.0001$ & 43 & $189-388$ & 298 \\
\hline 32 & Bitterroot River near Missoula & $\mathrm{TNQ}=0.000229(\mathrm{Q})^{1.14}$ & .86 & $<.0001$ & 55 & $355-678$ & 545 \\
\hline 33 & Clark Fork at St. Regis & $\mathrm{TNQ}=0.000231(\mathrm{Q})^{1.12}$ & .90 & $<.0001$ & 37 & $1,010-2,000$ & 1,560 \\
\hline 37 & Swan River near Bigfork & $\mathrm{TNQ}=0.0000469(\mathrm{Q})^{1.26}$ & .87 & $<.0001$ & 38 & $80.3-121$ & 106 \\
\hline 38 & Flathead River at Perma & $\mathrm{TNQ}=0.000584(\mathrm{Q})^{0.961}$ & .42 & $<.0001$ & 63 & $1,060-1,760$ & 1,500 \\
\hline
\end{tabular}

${ }^{1}$ Daily loads of total nitrogen were estimated from total nitrogen concentrations, which were estimated by adding concentrations of dissolved nitrite plus nitrate and total ammonia plus organic nitrogen.

${ }^{2}$ Less than 5 years of either sample data or daily mean streamflow record were available for load calculations. 
In the Missouri River basin, mean annual loads of total nitrogen ranged from 2.96 tons at Peoples Creek near Dodson to 3,450 tons at Missouri River near Culbertson. Annual loads of total nitrogen for individual years during 1999-2003 ranged from 0.72 ton at Peoples Creek near Dodson to 5,170 tons at Missouri River near Culbertson (fig. 22, table 7). The largest variation in annual loads during the 5-year period occurred at Poplar River near Poplar, where the smallest annual load was less than about 6 percent of the largest load. The smallest variation in annual loads of total nitrogen occurred at Sun River near Vaughn, where the smallest annual load was about 63 percent of the largest load.
The combined mean annual load of total nitrogen (3,270 tons) for Missouri River at Toston plus the downstream sampled tributaries accounted for about 95 percent of the mean annual load (3,450 tons) at Missouri River near Culbertson. The combined mean annual streamflows for these sites during water years 1999-2003 (table 4) represented only about 62 percent of the mean annual streamflow at Missouri River near Culbertson; therefore, the combined load from upstream sources was proportionally high relative to the combined streamflow. The largest mean annual load of total nitrogen from upstream sources was transported past Missouri River at Toston (1,680 tons), which accounted for about 49 percent

TOTAL NITROGEN

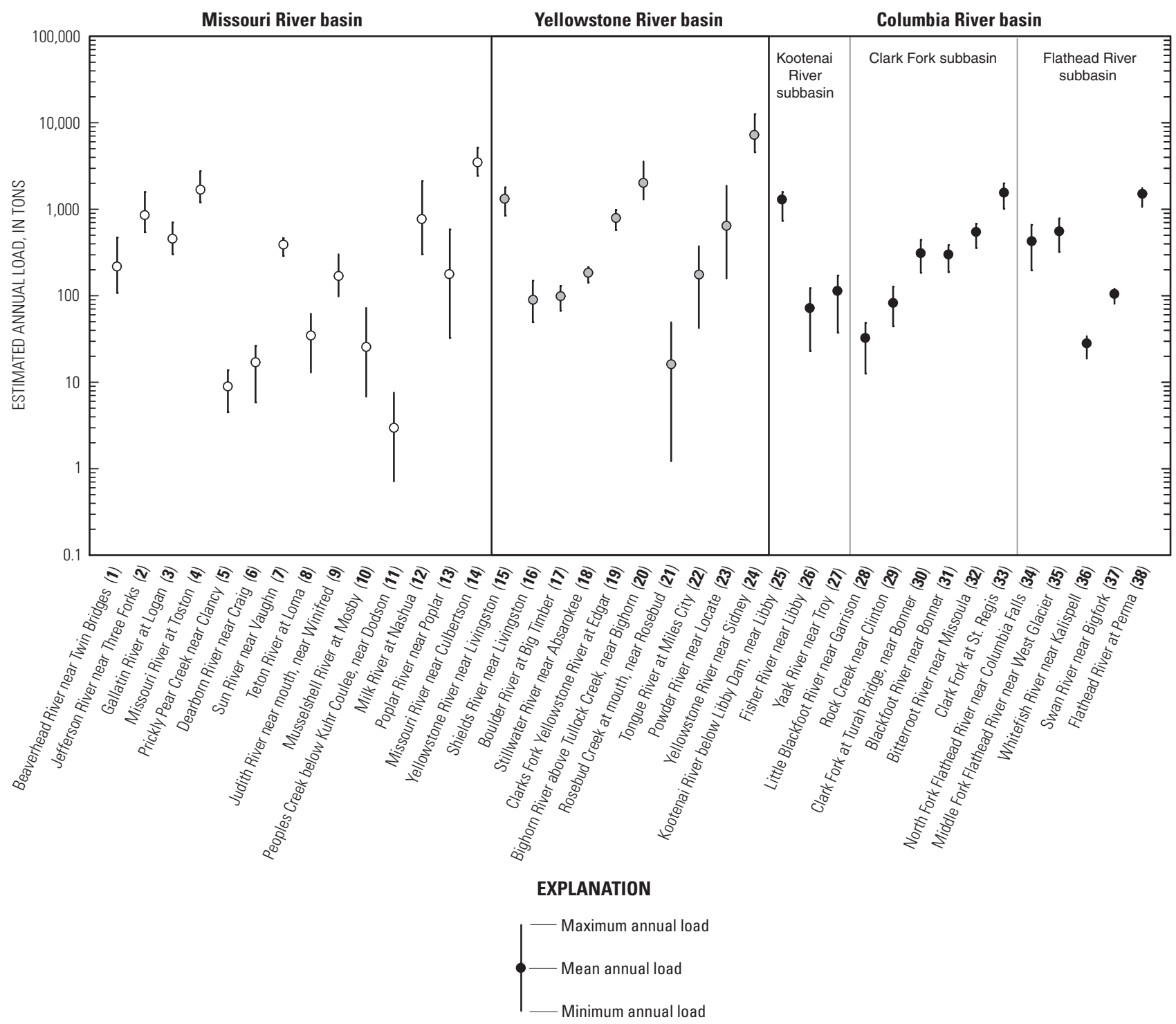

Figure 22. Range and mean of estimated annual loads of total nitrogen at network sites in Montana, water years $1999-2003$. Site number presented after station name (fig. 1, table 1). Equations used to estimate loads of total nitrogen were developed using estimated total nitrogen concentrations obtained by adding concentrations of dissolved nitrite plus nitrate and total ammonia plus organic nitrogen. 
of the mean annual load at Missouri River near Culbertson (table 7). The load from the basin above Toston was proportional to the streamflow contribution of about 46 percent. The next largest mean annual load of total nitrogen from upstream sources was transported past Milk River at Nashua (765 tons), which accounted for about 22 percent of the mean annual load at Missouri River near Culbertson; the load from the Milk River was proportionally high relative to the streamflow contribution of only about 4 percent.

In the Yellowstone River basin, mean annual loads of total nitrogen ranged from 16.1 tons at Rosebud Creek near Rosebud to 7,220 tons at Yellowstone River near Sidney. Annual loads of total nitrogen for individual years during 1999-2003 ranged from 1.22 tons at Rosebud Creek near Rosebud to 12,700 tons at Yellowstone River near Sidney (fig. 22, table 7). The largest variation in annual loads occurred at Rosebud Creek near Rosebud, where the smallest annual load was about 2 percent of the largest load. The smallest variation in annual loads occurred at Stillwater River near Absarokee, where the smallest annual load was about 68 percent of the largest load.

The combined mean annual load (5,340 tons) of total nitrogen for Yellowstone River near Livingston plus downstream sampled tributaries accounted for about 74 percent of the mean annual load (7,220 tons) at Yellowstone near Sidney. The combined mean annual streamflow for these sites during 1999-2003 (table 4) was within 2 percent of the flow at Yellowstone River near Sidney, thereby indicating that unmeasured sources are contributing about 26 percent of the total nitrogen load to the Yellowstone River near Sidney. The largest mean annual load from upstream sources was transported past Bighorn River near Bighorn (2,020 tons), which accounted for about 28 percent of the mean annual load at Yellowstone River near Sidney (table 7). The load from the Bighorn River is proportional to the streamflow contribution of about 31 percent. The next largest mean annual load from upstream sources was transported past Yellowstone River near Livingston (1,320 tons), which accounted for about 18 percent of the mean annual load at Yellowstone River near Sidney; however, the load from this source area was small relative to the streamflow contribution of about 39 percent.

In the Columbia River basin, mean annual loads of total nitrogen ranged from 28.0 tons at Whitefish River near Kalispell to 1,560 tons at Clark Fork at St. Regis. Annual loads of total nitrogen for individual years during 1999-2003 ranged from 12.6 tons at Little Blackfoot River near Garrison to 2,000 tons at Clark Fork at St. Regis (fig. 22, table 7). The largest variation in annual loads occurred at Fisher River near Libby, where the smallest annual load was about 19 percent of the largest load. The smallest variation in annual loads occurred at Swan River near Bigfork, where the smallest annual load was about 66 percent of the largest load.

In the Kootenai River subbasin of the Columbia River basin, the largest mean annual load of total nitrogen (1,290 tons) was transported past Kootenai River below Libby Dam (table 7). The much larger load at this site compared to the Yaak or Fisher Rivers is partly a function of the substantially greater streamflow (table 4), although concentrations of total nitrogen also were slightly higher at Kootenai River below Libby Dam (fig. 8). In the Clark Fork and Flathead River subbasins of the Columbia River basin, similar mean annual loads of total nitrogen were transported past Clark Fork at St. Regis (1,560 tons) and Flathead River at Perma (1,500 tons) (table 7). These loads represented about 51 and 49 percent, respectively, of the combined mean annual load (3,060 tons) for the Clark Fork at St. Regis and Flathead River at Perma. The mean annual load from the Clark Fork (51 percent) was proportionally high relative to the mean annual streamflow contribution of about 38 percent. The largest mean annual load of total nitrogen from sources in the Clark Fork subbasin upstream from St. Regis was transported past Bitterroot River near Missoula (545 tons), which accounted for about 35 percent of the mean annual load passing Clark Fork at St. Regis (table 7). The load from the Bitterroot River was proportional to the streamflow contribution of about 33 percent. The combined mean annual load of total nitrogen (1,150 tons) for Clark Fork at Turah Bridge, Blackfoot River near Bonner, and Bitterroot River near Missoula represented about 74 percent of the mean annual load (1,560 tons) at Clark Fork at St. Regis, which is proportional to the combined mean annual streamflow contribution of about 73 percent.

\section{Total Phosphorus}

Equations for estimating daily loads of total phosphorus at network sites are presented in table 8 , along with the range and mean of estimated annual loads during water years 1999-2003. Sites where censored concentrations exceeded 25 percent of the samples are noted in table 8 . At most sites, the data were logarithmically transformed prior to the regression analysis. At several sites, a square-root transformation of streamflow resulted in the best linear fit of the regression line. The equations for all sites were statistically significant (range of $\mathrm{p}$-values from $<0.0001$ to 0.0015$)$. Values of $\mathrm{R}^{2}$ ranged from 0.33 to 0.95 . Because of the low $R^{2}(0.33)$ of the equation for Flathead River near Perma, total phosphorus loads estimated for that site are subject to substantial error. The range and mean of estimated annual loads of total phosphorus at network sites during water years 1999-2003 are shown in figure 23 . Across the network, the means of the estimated annual loads of total phosphorus ranged from 0.22 to 1,930 tons (table 8 ).

In the Missouri River basin, mean annual loads of total phosphorus ranged from 0.22 ton at Peoples Creek near Dodson to 1,500 tons at Missouri River near Culbertson. Annual loads of total phosphorus for individual years during 1999-2003 ranged from 0.05 ton at Peoples Creek near Dodson to 2,540 tons at Missouri River near Culbertson (fig. 23, table 8). The largest variation in annual loads during the 5-year period occurred at Poplar River near Poplar, where the smallest load was less than 3 percent of the largest load. The smallest variation in annual loads occurred at Missouri River near Culbertson, where the smallest annual load was about 38 percent of the largest load. 
Table 8. Equations for estimating daily loads of total phosphorus and summaries of the range and mean of estimated annual loads at network sites in Montana, water years 1999-2003.

[Abbreviations: $\mathrm{R}^{2}$, coefficient of determinations; $\mathrm{p}$, significance level; SE, standard error, in percent; TPQ, total phosphorus discharge, in tons per day; Q, daily mean streamflow, in cubic feet per second; LOGTPQ, logarithm (base 10) of total phosphorus discharge, in tons per day. Symbol: <, less than]

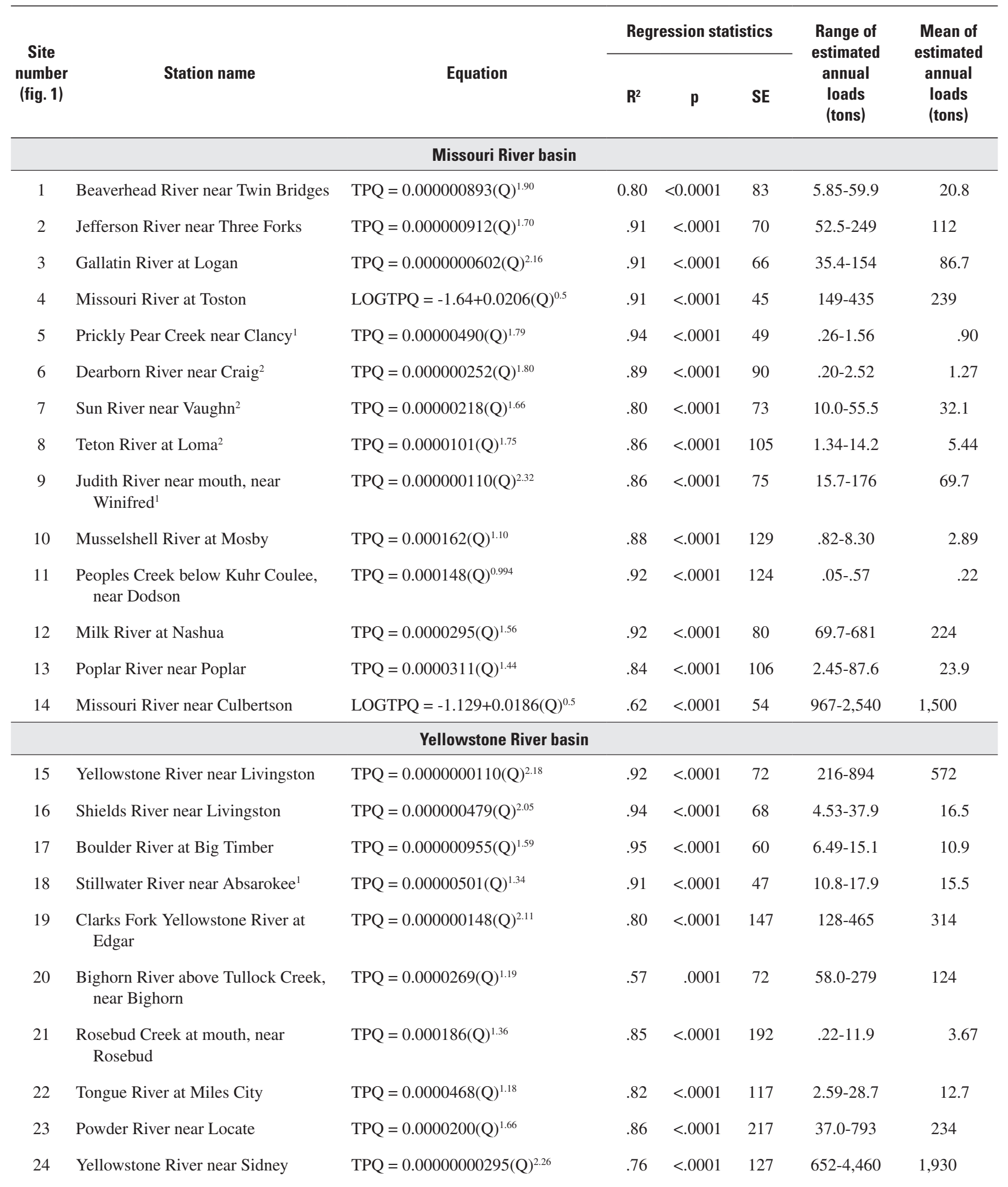


Table 8. Equations for estimating daily loads of total phosphorus and summaries of the range and mean of estimated annual loads at network sites in Montana, water years 1999-2003.-Continued

\begin{tabular}{|c|c|c|c|c|c|c|c|}
\hline \multirow{2}{*}{$\begin{array}{c}\text { Site } \\
\text { number } \\
\text { (fig. 1) }\end{array}$} & \multirow{2}{*}{ Station name } & \multirow{2}{*}{ Equation } & \multicolumn{3}{|c|}{ Regression statistics } & \multirow{2}{*}{$\begin{array}{c}\text { Range of } \\
\text { estimated } \\
\text { annual } \\
\text { loads } \\
\text { (tons) }\end{array}$} & \multirow{2}{*}{$\begin{array}{c}\text { Mean of } \\
\text { estimated } \\
\text { annual } \\
\text { loads } \\
\text { (tons) }\end{array}$} \\
\hline & & & $\mathbf{R}^{2}$ & $\mathbf{p}$ & SE & & \\
\hline \multicolumn{8}{|c|}{ Columbia River basin } \\
\hline 25 & $\begin{array}{l}\text { Kootenai River below Libby } \mathrm{Dam}^{2} \text {, } \\
\text { near Libby }\end{array}$ & $\mathrm{TPQ}=0.00000295(\mathrm{Q})^{1.12}$ & .72 & $<.0001$ & 49 & $19.3-41.6$ & 33.8 \\
\hline 26 & Fisher River near Libby & $\mathrm{TPQ}=0.000000120(\mathrm{Q})^{1.94}$ & .95 & $<.0001$ & 63 & $2.36-27.8$ & 12.8 \\
\hline 27 & Yaak River near Troy & $\mathrm{TPQ}=0.00000126(\mathrm{Q})^{1.39}$ & .93 & $<.0001$ & 60 & $1.70-9.72$ & 6.08 \\
\hline 28 & Little Blackfoot River near Garrison & $\mathrm{TPQ}=0.0000178(\mathrm{Q})^{1.40}$ & .94 & $<.0001$ & 47 & $2.18-9.40$ & 6.07 \\
\hline 29 & Rock Creek near Clinton & $\mathrm{TPQ}=0.00000100(\mathrm{Q})^{1.63}$ & .94 & $<.0001$ & 45 & $4.69-17.1$ & 10.4 \\
\hline 30 & $\begin{array}{l}\text { Clark Fork at Turah Bridge, near } \\
\text { Bonner }\end{array}$ & $\mathrm{TPQ}=0.000000209(\mathrm{Q})^{1.86}$ & .93 & $<.0001$ & 42 & $19.4-74.8$ & 46.7 \\
\hline 31 & Blackfoot River near Bonner & $\mathrm{TPQ}=0.0000000178(\mathrm{Q})^{2.04}$ & .95 & $<.0001$ & 51 & $15.2-55.2$ & 36.6 \\
\hline 32 & Bitterroot River near Missoula & $\mathrm{TPQ}=0.00000158(\mathrm{Q})^{1.49}$ & .88 & $<.0001$ & 67 & $39.0-98.1$ & 73.7 \\
\hline 33 & Clark Fork at St. Regis & $\mathrm{TPQ}=0.0000000912(\mathrm{Q})^{1.72}$ & .90 & $<.0001$ & 59 & $81.6-268$ & 183 \\
\hline 34 & $\begin{array}{l}\text { North Fork Flathead River near } \\
\text { Columbia Falls }\end{array}$ & LOGTPQ $=-2.83+0.0282(\mathrm{Q})^{0.5}$ & .91 & $<.0001$ & 72 & 19.2-308 & 113 \\
\hline 35 & $\begin{array}{l}\text { Middle Fork Flathead River near } \\
\text { West Glacier }\end{array}$ & LOGTPQ $=-2.75+0.0255(\mathrm{Q})^{0.5}$ & .83 & $<.0001$ & 100 & $20.5-154$ & 64.1 \\
\hline 36 & Whitefish River near Kalispell & $\mathrm{TPQ}=0.0000200(\mathrm{Q})^{1.10}$ & .82 & $<.0001$ & 50 & $1.05-2.32$ & 1.85 \\
\hline 37 & Swan River near Bigfork ${ }^{2}$ & $\mathrm{TPQ}=0.0000162(\mathrm{Q})^{0.907}$ & .71 & $<.0001$ & 46 & $2.34-3.17$ & 2.84 \\
\hline 38 & Flathead River at Perma & $\mathrm{TPQ}=0.0000295(\mathrm{Q})^{0.922}$ & .33 & .0015 & 90 & $37.8-61.3$ & 52.6 \\
\hline
\end{tabular}

${ }^{1}$ Less than 5 years of either sample data or daily mean streamflow record were available for load calculations.

${ }^{2}$ More than 25 percent of the analytical values used for load calculations are less than the laboratory reporting level.

The combined mean annual load of total phosphorus (599 tons) for Missouri River at Toston plus the downstream sampled tributaries accounted for only about 40 percent of the mean annual load (1,500 tons) at Missouri River near Culbertson. The combined mean annual streamflow for these sites (table 4) during water years 1999-2003 was about 62 percent of the streamflow at Missouri River near Culbertson; therefore, the combined load of total phosphorus from upstream sources is low relative to the combined streamflow. The small percentage of load implies that additional, unmeasured sources are contributing substantial quantities of total phosphorus to the mainstem. The largest mean annual load of total phosphorus from the upstream sources was transported past Missouri River at Toston (239 tons), which accounted for about 16 per- cent of the mean annual load at Missouri River near Culbertson (table 8). However, this load was proportionally small relative to the streamflow contribution of about 46 percent. The combined mean annual loads from Jefferson River near Three Forks and Gallatin River at Logan accounted for 83 percent of the load at Missouri River at Toston, indicating that the Madison River (which was not sampled) probably accounted for about 17 percent of the load. The next largest mean annual load of total phosphorus from upstream sources was transported past Milk River at Nashua (224 tons), which accounted for about 15 percent of the mean annual load at Missouri River near Culbertson; this load was proportionally high relative to the streamflow contribution of only about 4 percent. 
In the Yellowstone River basin, mean annual loads of total phosphorus ranged from 3.67 tons at Rosebud Creek near Rosebud to 1,930 tons at Yellowstone River near Sidney. Annual loads of total phosphorus for individual years during 1999-2003 ranged from 0.22 ton at Rosebud Creek near Rosebud to 4,460 tons at Yellowstone River near Sidney (fig. 23, table 8). The largest variation in annual loads occurred at Rosebud Creek near Rosebud, where the smallest annual load was less than 2 percent of the largest load. The smallest variation in annual loads occurred at Stillwater River near Absarokee, where the smallest annual load was about 60 percent of the largest load.

The combined mean annual load of total phosphorus (1,300 tons) for Yellowstone River near Livingston plus the downstream sampled tributaries accounted for about 67 percent of the mean annual load at Yellowstone River near Sidney (1,930 tons). The combined mean annual streamflows for these sites during water years 1999-2003 (table 4) represented essentially 100 percent of the mean annual streamflow at Yellowstone River near Sidney; therefore, the combined load from upstream sources was proportionally low relative to the combined streamflow. The relatively low percentage of load relative to streamflow indicates that unmeasured sources are contributing about 33 percent of the total phosphorus load at Yellowstone River at Sidney. The largest mean annual load of total phosphorus from upstream sources was transported past Yellowstone River near Livingston (572 tons), which accounted for about 30 percent of the mean annual load at

\section{TOTAL PHOSPHORUS}

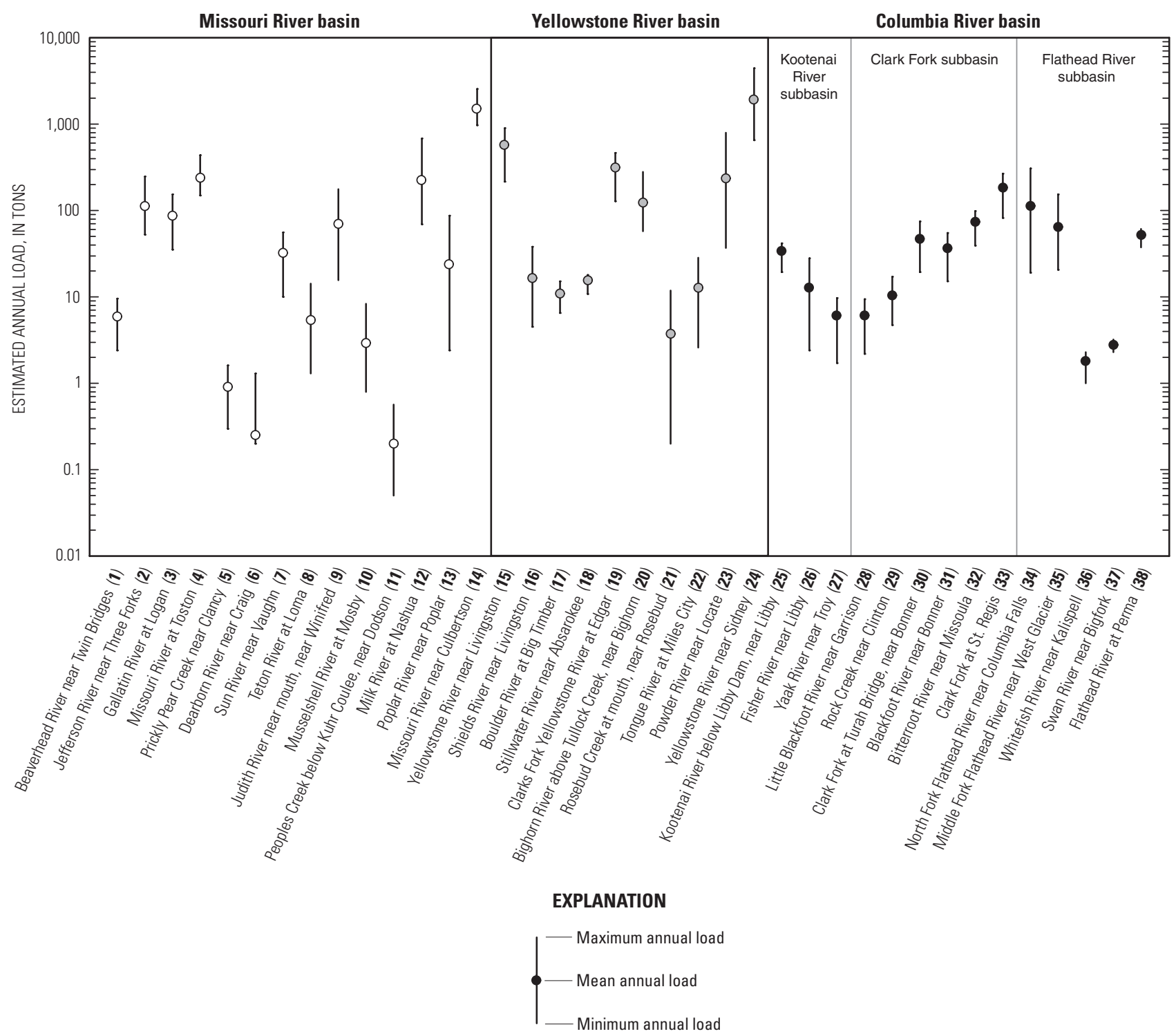

Figure 23. Range and mean of estimated annual loads of total phosphorus at network sites in Montana, water years $1999-2003$. Site number presented after station name (fig. 1, table 1). 
Yellowstone River near Sidney (table 8). The mean annual load at Yellowstone River near Livingston was slightly low relative to the mean annual streamflow contribution of about 39 percent. The next largest mean annual load from upstream sources was transported past Clarks Fork Yellowstone River at Edgar (314 tons), which accounted for about 16 percent of the load at Yellowstone River near Sidney; the load from Clarks Fork Yellowstone River was slightly high relative to the streamflow contribution of about 10 percent. Relatively large mean annual loads of total phosphorus also were transported past Bighorn River near Bighorn (124 tons) and Powder River near Locate (234 tons). The mean annual load at Bighorn River near Bighorn represented only about 6 percent of the mean annual load at Yellowstone River near Sidney, which was small relative to the streamflow contribution of about 31 percent. The Powder River near Locate accounted for about 12 percent of the load at Yellowstone River near Sidney, but contributed only about 4 percent of the streamflow.

In the Columbia River basin, mean annual loads of total phosphorus ranged from 1.85 tons at Whitefish River near Kalispell to 183 tons at Clark Fork at St. Regis. Annual loads of total phosphorus for individual years during 19992003 ranged from 1.05 tons at Whitefish River near Kalispell to 308 tons at North Fork Flathead River near Columbia Falls (fig. 23, table 8). The largest variation in annual loads occurred at North Fork Flathead River near Columbia Falls, where the smallest annual load was only about 6 percent of the largest. The smallest variation in annual loads occurred at Swan River near Bigfork, where the smallest annual load was about 74 percent of the largest load.

In the Kootenai River subbasin of the Columbia River basin, the largest mean annual load of total phosphorus (33.8 tons) was transported past Kootenai River below Libby Dam (table 8). Similar to the other nutrients, this large load is primarily a function of the large streamflow, rather than high concentrations (fig. 10). In the Clark Fork and Flathead River subbasins of the Columbia River basin, the largest mean annual load (183 tons) was transported past Clark Fork at St. Regis, which accounted for about 78 percent of the combined mean annual load (236 tons) of Clark Fork at St. Regis plus Flathead River at Perma (table 8). The mean annual load at Clark Fork at St. Regis was proportionally high relative to the mean annual streamflow contribution of about 38 percent (table 4); however, the regression relation for Flathead River at Perma (table 8 ) had a low $\mathrm{R}^{2}$ of 0.33 , which may result in considerable error in estimated annual loads. The largest mean annual load of total phosphorus from sources in the Clark Fork subbasin upstream from St. Regis was transported past Bitterroot River near Missoula (73.7 tons), which accounted for about 40 percent of the load at Clark Fork at St. Regis (table 8). The mean annual load from the Bitterroot River was slightly high relative to the mean annual streamflow contribution of about 33 percent. The combined mean annual load of total phosphorus (157 tons) for Clark Fork at Turah Bridge, Blackfoot River near Bonner, and Bitterroot River near Missoula represented about 86 percent of the mean annual load at
Clark Fork at St. Regis, which is moderately higher relative to the combined streamflow contribution of about 73 percent.

\section{Suspended Sediment}

Equations for estimating daily loads of suspended sediment at the network sites are presented in table 9, along with the range and mean of estimated annual loads during water years 1999-2003. The equations for all sites were statistically significant (range of p-values from 0.001 to $<0.0001$ ). Values of $\mathrm{R}^{2}$ ranged from 0.46 to 0.96 ; most sites had $\mathrm{R}^{2}$ values of 0.80 or higher. The range and mean of estimated suspendedsediment loads at network sites during water years 1999-2003 are shown in figure 24. Across the network, the means of the estimated annual loads of suspended sediment ranged from 262 to 2,890,000 tons (table 9).

In several instances, the approach to estimating annual loads was modified to accommodate the sediment-transport conditions that were unique at some sites (noted in table 9). For most sites, the data were transformed to either logarithms or square roots to achieve the best fit to the linear regression line; at one site (Bighorn River near Bighorn), the relation was developed using untransformed data. At Musselshell River at Mosby and Powder River near Locate, separate regression relations were developed for different flow ranges because a distinctly different slope in the relation was observed for low-flow and high-flow conditions. Using the visual distribution of the plotted data as a guide, thresholds of $14 \mathrm{ft}^{3} / \mathrm{s}$ for Musselshell River at Mosby and $36 \mathrm{ft}^{3} / \mathrm{s}$ for Powder River near Locate were determined to represent a break in slope of the regression line. Each of the separate regression relations was statistically significant and was applied to those days having daily mean streamflow within the ranges specified by the equations (table 9). In the Columbia River basin, the nearly constant concentrations of suspended sediment at two sites (Kootenai River below Libby Dam and Swan River near Bigfork) downstream from large lakes allowed loads to be calculated by multiplication of daily mean streamflow by the mean suspended-sediment concentration determined from the periodic samples (table 15) and a units-conversion constant.

In the Missouri River basin, mean annual loads of suspended sediment ranged from 262 tons at Peoples Creek near Dodson to 2,350,000 tons at Missouri River near Culbertson. Annual loads of suspended sediment for individual years during 1999-2003 ranged from 52.4 tons at Peoples Creek near Dodson to 3,860,000 tons at Missouri River near Culbertson (fig. 24, table 9). At most sites in the Missouri River basin, annual loads varied by about a factor of 10 during the 5-year period, with the exception of Missouri River near Culbertson, which varied by a factor of less than 3 (fig. 24). The largest variation in annual loads occurred at Poplar River near Poplar, with the smallest annual load being only about 5 percent of the largest load. The smallest variation occurred at Missouri River near Culbertson where the smallest annual load was about 39 percent of the largest load. 
Table 9. Equations for estimating daily loads of suspended sediment and summaries of the range and mean of estimated annual loads at network sites in Montana, water years 1999-2003.

[Abbreviations: $\mathrm{R}^{2}$, coefficient of determination; $\mathrm{p}$, significance level; SE, standard error, in percent; SEDQ, suspended-sediment discharge, in tons per day; Q, daily mean streamflow, in cubic feet per second; LOGSEDQ, logarithm (base 10) of suspended-sediment discharge, in tons per day; $\mathrm{ft}^{3} / \mathrm{s}$, cubic feet per second. Symbol: >, greater than; <, less than; --, regression equation not significant at $\mathrm{p}=0.05$ ]

\begin{tabular}{|c|c|c|c|c|c|c|c|}
\hline \multirow{2}{*}{$\begin{array}{c}\text { Site } \\
\text { number } \\
\text { (fig. 1) }\end{array}$} & \multirow{2}{*}{ Station name } & \multirow{2}{*}{ Equation } & \multicolumn{3}{|c|}{ Regression statistics } & \multirow{2}{*}{$\begin{array}{c}\text { Range of } \\
\text { estimated } \\
\text { annual } \\
\text { loads } \\
\text { (tons) }\end{array}$} & \multirow{2}{*}{$\begin{array}{c}\text { Mean of } \\
\text { estimated } \\
\text { annual } \\
\text { loads } \\
\text { (tons) }\end{array}$} \\
\hline & & & $\mathbf{R}^{2}$ & $\mathbf{p}$ & SE & & \\
\hline \multicolumn{8}{|c|}{ Missouri River basin } \\
\hline 2 & Jefferson River near Three Forks & SEDQ $=0.0000611(\mathrm{Q})^{1.99}$ & .92 & $<.0001$ & 77 & $27,900-188,000$ & 77,000 \\
\hline 3 & Gallatin River at Logan & $\mathrm{SEDQ}=0.00000113(\mathrm{Q})^{2.63}$ & .91 & $<.0001$ & 85 & $19,500-134,000$ & 70,200 \\
\hline 4 & Missouri River at Toston & $\begin{array}{l}\text { LOGSEDQ = } \\
\quad 0.615+0.0258(\mathrm{Q})^{0.5}\end{array}$ & .92 & $<.0001$ & 53 & $44,300-317,000$ & 128,000 \\
\hline 7 & Sun River near Vaughn & $\mathrm{SEDQ}=0.00102(\mathrm{Q})^{1.80}$ & .84 & $<.0001$ & 68 & $10,600-76,900$ & 41,500 \\
\hline 8 & Teton River at Loma & $\mathrm{SEDQ}=0.0126(\mathrm{Q})^{1.81}$ & .89 & $<.0001$ & 89 & $2,140-26,100$ & 9,760 \\
\hline 9 & Judith River near mouth, near Winifred ${ }^{1}$ & $\mathrm{SEDQ}=0.000620(\mathrm{Q})^{2.10}$ & .88 & $<.0001$ & 60 & $25,400-168,000$ & 73,500 \\
\hline \multirow[t]{2}{*}{10} & Musselshell River at Mosby $\left(<14 \mathrm{ft}^{3} / \mathrm{s}\right)^{2}$ & $\mathrm{SEDQ}=0.268(\mathrm{Q})^{0.818}$ & .92 & $<.0001$ & 55 & \multirow{2}{*}{$4,630-39,200$} & \multirow{2}{*}{19,800} \\
\hline & Musselshell River at Mosby $\left(>14 \mathrm{ft}^{3} / \mathrm{s}\right)^{2}$ & $\mathrm{SEDQ}=0.00729(\mathrm{Q})^{2.08}$ & .90 & $<.0001$ & 63 & & \\
\hline 11 & $\begin{array}{l}\text { Peoples Creek below Kuhr Coulee, near } \\
\text { Dodson }\end{array}$ & $\mathrm{SEDQ}=0.104(\mathrm{Q})^{1.13}$ & .94 & $<.0001$ & 125 & $52.4-630$ & 262 \\
\hline 15 & Yellowstone River near Livingston & $\mathrm{SEDQ}=0.0000000749(\mathrm{Q})^{2.69}$ & .93 & $<.0001$ & 88 & $137,000-810,000$ & 496,000 \\
\hline 16 & Shields River near Livingston & $\begin{array}{l}\text { LOGSEDQ }= \\
\quad-0.240+0.0997(Q)^{0.5}\end{array}$ & .90 & $<.0001$ & 79 & $3,200-66,108$ & 21,100 \\
\hline 17 & Boulder River at Big Timber & $\mathrm{SEDQ}=0.000181(\mathrm{Q})^{1.78}$ & .87 & $<.0001$ & 137 & $4,850-12,600$ & 8,870 \\
\hline 18 & Stillwater River near Absarokee $^{1}$ & $\mathrm{SEDQ}=0.000234(\mathrm{Q})^{1.65}$ & .92 & $<.0001$ & 58 & $4,720-9,340$ & 7,790 \\
\hline 19 & Clarks Fork Yellowstone River at Edgar & $\mathrm{SEDQ}=0.000177(\mathrm{Q})^{2.08}$ & .74 & $<.0001$ & 190 & $127,000-453,000$ & 306,000 \\
\hline 20 & $\begin{array}{l}\text { Bighorn River above Tullock Creek, } \\
\text { near Bighorn }\end{array}$ & SEDQ $=-192+0.273(Q)$ & .63 & $<.0001$ & 534 & $76,500-472,000$ & 200,000 \\
\hline 21 & Rosebud Creek at mouth, near Rosebud & $\mathrm{SEDQ}=0.385(\mathrm{Q})^{1.35}$ & .86 & $<.0001$ & 182 & $436-23,500$ & 7,280 \\
\hline 22 & Tongue River at Miles City & SEDQ $=0.0658(Q)^{1.37}$ & .80 & $<.0001$ & 163 & $8,440-145,000$ & 59,100 \\
\hline
\end{tabular}


Table 9. Equations for estimating daily loads of suspended sediment and summaries of the range and mean of estimated annual loads at network sites in Montana, water years 1999-2003.-Continued

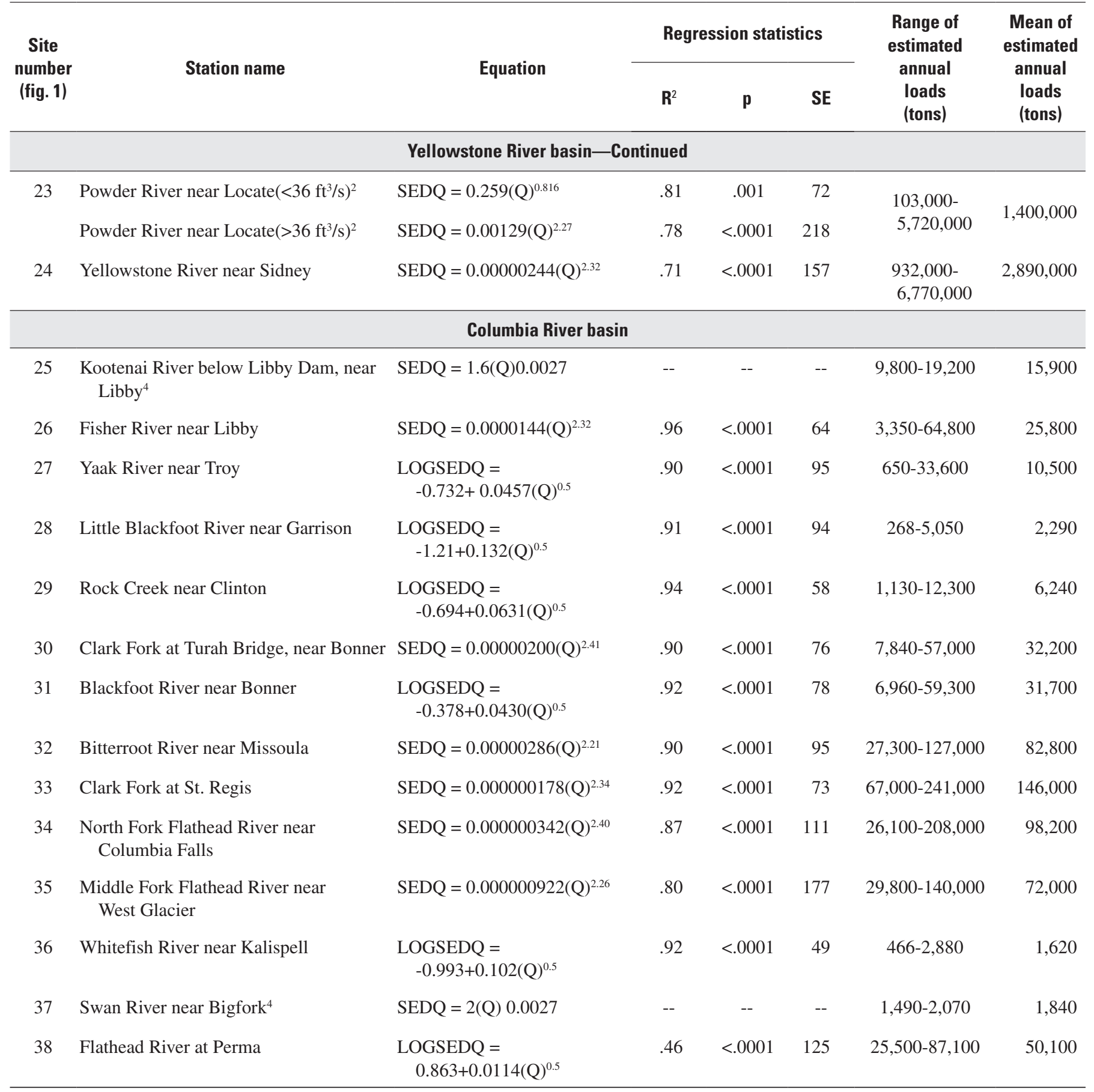

${ }^{1}$ Less than 5 years of either sample data or daily mean streamflow record were available for load calculations.

${ }^{2}$ Separate regressions were developed for each of the two flow ranges indicated to account for distinctly different slopes in regression relations for low-flow and high-flow conditions. Daily loads for both flow ranges were summed to produce annual loads.

${ }^{3}$ Regression equation was developed from untransformed data; standard error reported in units of tons per day rather than percent.

${ }^{4}$ Daily loads were calculated by multiplying by the mean concentration (table 15) determined from periodic samples by the daily mean streamflow and units conversion constant. 
The largest mean annual suspended-sediment load contributed to the mainstem from upstream sources was transported past Milk River at Nashua (319,000 tons), which accounted for about 14 percent of the mean annual load at Missouri River near Culbertson. The suspended-sediment load from the Milk River was proportionally high relative to the streamflow contribution of only about 4 percent (table 4 ).

Only about 26 percent of the mean annual suspended-sediment load at Missouri River near Culbertson (2,350,000 tons) can be accounted for by the combined load (620,000 tons) for Missouri River at Toston plus sampled tributaries downstream from Toston (table 9). The source of the remaining 74 percent of the suspended-sediment load (1,730,000 tons) at Missouri River near Culbertson that is unaccounted for by network sites can only be speculated. Two large tributaries (Smith and Marias Rivers not part of the statewide network, fig. 1) might have contributed part of the unmeasured load. If these streams contribute sediment loads similar in magnitude to other tributaries of similar size, the suspended-sediment load at Missouri River near Culbertson would likely still be substantially greater than the combined loads from the upstream parts of the basin. This is even more notable because the four major reservoirs on the mainstem downstream from Missouri River at Toston (Canyon Ferry, Hauser, Holter, and Fort Peck; fig. 1) likely trap a large percentage of the suspended-sediment load derived from source areas upstream from Fort Peck Reservoir. The large suspended-sediment load passing Missouri River near Culbertson, despite the likely depositional loss of

SUSPENDED SEDIMENT

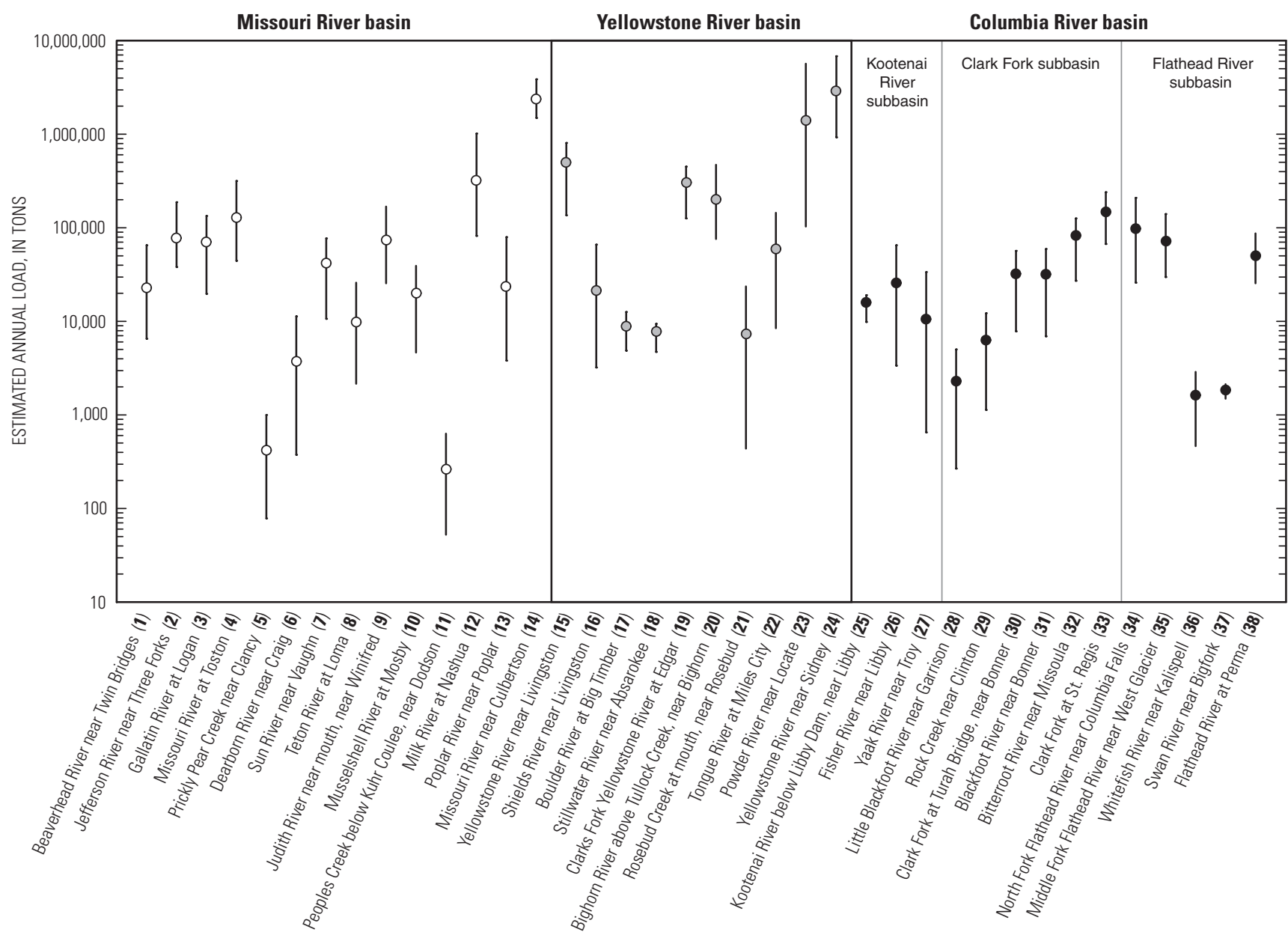

EXPLANATION

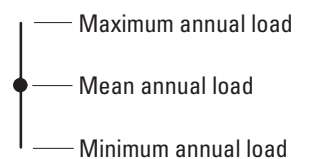

Figure 24. Range and mean of estimated annual loads of suspended sediment at network sites in Montana, water years $1999-2003$. Site number presented after station name (fig. 1, table 1). 
upstream sediment load in mainstem reservoirs, indicates that large quantities of sediment are being derived from sources downstream from Fort Peck Reservoir. Although the suspended-sediment load passing through Fort Peck Reservoir is unknown, the load is presumably much less than the load entering the reservoir due to deposition within the reservoir. The combined load (342,600 tons) of the two major tributaries (Milk and Poplar Rivers) discharging to the mainstem downstream from Fort Peck Reservoir only accounts for about 15 percent of the load at the Missouri River near Culbertson. If it is assumed that the outflow from Fort Peck Reservoir is not accounting for the remaining 85 percent of load, then a substantial portion of the suspended-sediment load at Missouri River near Culbertson might be derived from either unsampled tributaries or channel erosion downstream from Fort Peck Reservoir.

In the Yellowstone River basin, mean annual suspendedsediment loads ranged from 7,280 tons at Rosebud Creek near Rosebud to 2,890,000 tons at Yellowstone River near Sidney. Annual loads of suspended sediment for individual years during 1999-2003 in the Yellowstone River basin ranged from 436 tons at Rosebud Creek near Rosebud to 6,770,000 tons at Yellowstone River near Sidney (fig. 24, table 9). The largest variation in annual loads occurred at Rosebud Creek near Rosebud and Powder River near Locate, where the smallest loads were less than 2 percent of the largest loads. The smallest variation in annual loads occurred at Stillwater River near Absarokee, where the smallest annual load was about 51 percent of the largest load.

The combined mean annual load of suspended sediment (2,510,000 tons) for Yellowstone River near Livingston plus downstream sampled tributaries accounted for about 87 percent of the mean annual load (2,890,000 tons) at Yellowstone River near Sidney (table 9), which was proportionally slightly lower than the combined streamflow contribution of about 100 percent (table 4). The largest mean annual load of suspended sediment from upstream sources was transported past Powder River near Locate (1,400,000 tons), which accounted for nearly one-half (about 48 percent) of the mean annual load at Yellowstone River near Sidney. The suspended-sediment load from the Powder River was proportionally very large relative to the mean annual streamflow contribution of only about 4 percent. Other relatively large mean annual loads were transported past Yellowstone River near Livingston (496,000 tons) and Clarks Fork Yellowstone River at Edgar (306,000 tons). The mean annual load at Yellowstone River near Livingston represented only about 17 percent of the load at Yellowstone River near Sidney, which was proportionally small relative to the mean annual streamflow contribution of about 39 percent. Clarks Fork Yellowstone River contributed proportionally similar amounts of suspended-sediment load (about 11 percent) and streamflow (about 10 percent).

In the Columbia River basin, mean annual loads of suspended sediment ranged from 1,620 tons at Whitefish River near Kalispell to 146,000 tons at Clark Fork at St. Regis. Annual loads of suspended-sediment for individual years during 1999-2003 ranged from 268 tons at Little Blackfoot River near Garrison to 241,000 tons at Clark Fork at St. Regis (fig. 24, table 9). Yaak River near Troy had the largest variation in annual loads, with the smallest annual load being only about 2 percent of the largest annual load. The smallest variation in annual loads occurred at Swan River near Bigfork, where the smallest annual load was about 72 percent of the largest load.

In the Kootenai River subbasin of the Columbia River basin, the largest mean annual load of suspended-sediment (25,800 tons) was transported past Fisher River near Libby (table 9). In the Clark Fork and Flathead River subbasins of the Columbia River basin, the largest mean annual load was transported past Clark Fork at St. Regis (146,000 tons), accounting for about 74 percent of the combined mean annual load (196,000 tons) of Clark Fork at St. Regis plus Flathead River at Perma. The mean annual load at Clark Fork at St. Regis was proportionally high relative to the mean annual streamflow contribution of 38 percent (table 4); however, the regression relation for Flathead River at Perma (table 9) had a low $\mathrm{R}^{2}$ of 0.46 , which may result in considerable error in estimated annual loads. In the Clark Fork subbasin upstream from St. Regis, the largest mean annual load of suspended sediment was transported past Bitterroot River near Missoula (82,800 tons), which accounted for about 57 percent of the load at Clark Fork at St. Regis. The mean annual load from the Bitterroot River proportionally was substantially larger than the mean annual streamflow contribution of about 33 percent. The combined mean annual load of suspended sediment (146,700 tons) for Clark Fork at Turah Bridge, Blackfoot River near Bonner, and Bitterroot River near Missoula represented essentially 100 percent of the mean annual load (146,000 tons) at Clark Fork at St. Regis, which is high relative to the combined streamflow contribution of about 73 percent.

\section{Dissolved Solids}

Equations for estimating daily loads of dissolved solids at network sites are presented in table 10, along with the range and mean of estimated annual loads during water years 19992003. Dissolved solids (calculated as the sum of constituents, table 15) were analyzed at a frequency of only two times per year, thereby minimizing the extent of seasonal and hydrologic characterization available for developing regression relations. For all sites, the data were logarithmically transformed to produce the best linear fit of the regression line. All equations were highly significant $(\mathrm{p}<0.0001)$. Values of $\mathrm{R}^{2}$ ranged from 0.71 to 0.99 , indicating that estimated annual loads of dissolved solids likely are reasonably accurate. The range and mean of estimated dissolved-solids loads are shown in figure 25. Across the network, the means of the estimated annual loads of dissolved solids ranged from 2,830 to 2,970,000 tons (table 10). 
Table 10. Equations for estimating daily loads of dissolved solids and summaries of the range and mean of estimated annual loads at network sites in Montana, water years 1999-2003.

[Abbreviations: $\mathrm{R}^{2}$, coefficient of determination; $\mathrm{p}$, significance level; SE, standard error, in percent; DSQ, dissolved-solids discharge, in tons per day; Q, daily mean streamflow, in cubic feet per second. Symbol: <, less than]

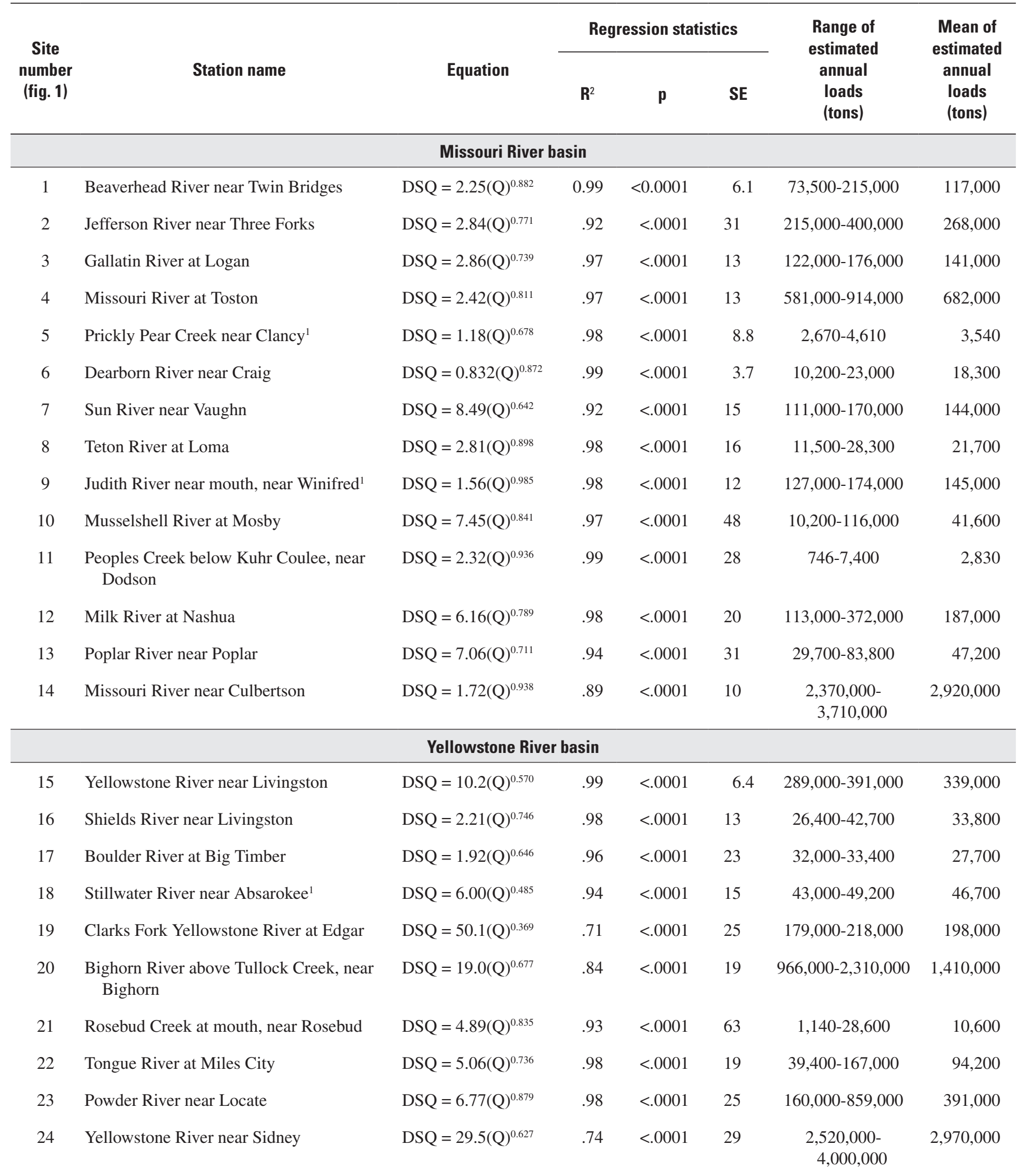


Table 10. Equations for estimating daily loads of dissolved solids and summaries of the range and mean of estimated annual loads at network sites in Montana, water years 1999-2003.-Continued

\begin{tabular}{|c|c|c|c|c|c|c|c|}
\hline \multirow{2}{*}{$\begin{array}{c}\text { Site } \\
\text { number } \\
\text { (fig. 1) }\end{array}$} & \multirow{2}{*}{ Station name } & \multirow{2}{*}{ Equation } & \multicolumn{3}{|c|}{ Regression statistics } & \multirow{2}{*}{$\begin{array}{c}\text { Range of } \\
\text { estimated } \\
\text { annual } \\
\text { loads } \\
\text { (tons) }\end{array}$} & \multirow{2}{*}{$\begin{array}{c}\text { Mean of } \\
\text { estimated } \\
\text { annual } \\
\text { loads } \\
\text { (tons) }\end{array}$} \\
\hline & & & $\mathbf{R}^{2}$ & $\mathbf{p}$ & SE & & \\
\hline \multicolumn{8}{|c|}{ Columbia River basin } \\
\hline 25 & $\begin{array}{l}\text { Kootenai River below Libby Dam, near } \\
\text { Libby }\end{array}$ & $\mathrm{DSQ}=1.90(\mathrm{Q})^{0.815}$ & .98 & $<.0001$ & 7.1 & $845,000-1,440,000$ & $1,230,000$ \\
\hline 26 & Fisher River near Libby & $\mathrm{DSQ}=1.49(\mathrm{Q})^{0.664}$ & .98 & $<.0001$ & 12 & $15,800-32,500$ & 26,000 \\
\hline 27 & Yaak River near Troy & $\mathrm{DSQ}=0.572(\mathrm{Q})^{0.762}$ & .98 & $<.0001$ & 16 & $13,700-33,800$ & 26,300 \\
\hline 28 & Little Blackfoot River near Garrison & $\mathrm{DSQ}=0.936(\mathrm{Q})^{0.827}$ & .98 & $<.0001$ & 6.7 & $33,300-89,200$ & 68,100 \\
\hline 29 & Rock Creek near Clinton & $\mathrm{DSQ}=1.23(\mathrm{Q})^{0.693}$ & .99 & $<.0001$ & 3.8 & $22,300-32,700$ & 26,700 \\
\hline 30 & Clark Fork at Turah Bridge, near Bonner & $\mathrm{DSQ}=7.09(\mathrm{Q})^{0.628}$ & .85 & $<.0001$ & 20 & $165,000-231,000$ & 195,000 \\
\hline 31 & Blackfoot River near Bonner & $\mathrm{DSQ}=1.70(\mathrm{Q})^{0.752}$ & .99 & $<.0001$ & 5.1 & $103,000-149,000$ & 128,000 \\
\hline 32 & Bitterroot River near Missoula & $\mathrm{DSQ}=3.26(\mathrm{Q})^{0.603}$ & .98 & $<.0001$ & 11 & $87,400-117,000$ & 104,000 \\
\hline 33 & Clark Fork at St. Regis & $\mathrm{DSQ}=6.60(\mathrm{Q})^{0.641}$ & .97 & $<.0001$ & 12 & $477,000-677,000$ & 586,000 \\
\hline 34 & $\begin{array}{l}\text { North Fork Flathead River near Columbia } \\
\text { Falls }\end{array}$ & $\mathrm{DSQ}=0.887(\mathrm{Q})^{0.843}$ & .99 & $<.0001$ & 3.7 & $145,000-287,000$ & 231,000 \\
\hline 35 & $\begin{array}{l}\text { Middle Fork Flathead River near West } \\
\text { Glacier }\end{array}$ & $\mathrm{DSQ}=0.510(\mathrm{Q})^{0.888}$ & .99 & $<.0001$ & 7.6 & $121,000-229,000$ & 183,000 \\
\hline 36 & Whitefish River near Kalispell & $\mathrm{DSQ}=2.85(\mathrm{Q})^{0.947}$ & .99 & $<.0001$ & 3.0 & $71,800-141,000$ & 118,000 \\
\hline 37 & Swan River near Bigfork & $\mathrm{DSQ}=0.315(\mathrm{Q})^{0.958}$ & .99 & $<.0001$ & 6.5 & $64,800-89,100$ & 79,500 \\
\hline 38 & Flathead River at Perma & $\mathrm{DSQ}=0.386(\mathrm{Q})^{0.956}$ & .99 & $<.0001$ & 3.4 & $669,000-1,110,000$ & 946,000 \\
\hline
\end{tabular}

${ }^{1}$ Less than 5 years of either sample data or daily mean streamflow record were available for load calculations.

In the Missouri River basin, mean annual loads of dissolved solids ranged from 2,830 tons at Peoples Creek near Dodson to 2,920,000 tons at Missouri River near Culbertson. Annual loads of dissolved solids for individual years during 1999-2003 ranged from 746 tons at Peoples Creek near Dodson to 3,710,000 tons at Missouri River near Culbertson (fig. 25, table 10). The largest variation in annual loads occurred at Musselshell River at Mosby, where the smallest annual load was only about 9 percent of the largest load. The smallest variation occurred at Judith River near Winifred, where the smallest annual load was about 73 percent of the largest load. With the exception of Musselshell River at Mosby and Peoples Creek near Dodson, the variation in loads between years generally was small, with most differences between the smallest and largest maximum annual loads representing only about a 2 - to 3 -fold difference.
The combined mean annual load of dissolved solids (about 1,290,000 tons) for Missouri River at Toston plus downstream sampled tributaries accounted for only about 44 percent of the mean annual load (2,920,000 tons) at Missouri River near Culbertson. This combined load is small relative to the combined mean annual streamflow contribution of about 62 percent (table 4), indicating that unmeasured sources in the Missouri River basin in the intervening reach from Toston to Culbertson are contributing substantial loads of dissolved solids to the mainstem. The largest mean annual load of dissolved solids from upstream sources was transported past Missouri River at Toston (682,000 tons), accounting for about 23 percent of the load at Missouri River near Culbertson. However, this load was proportionally small relative to the mean annual streamflow contribution of about 46 percent. Other relatively large mean annual loads of dissolved solids 


\section{DISSOLVED SOLIDS}

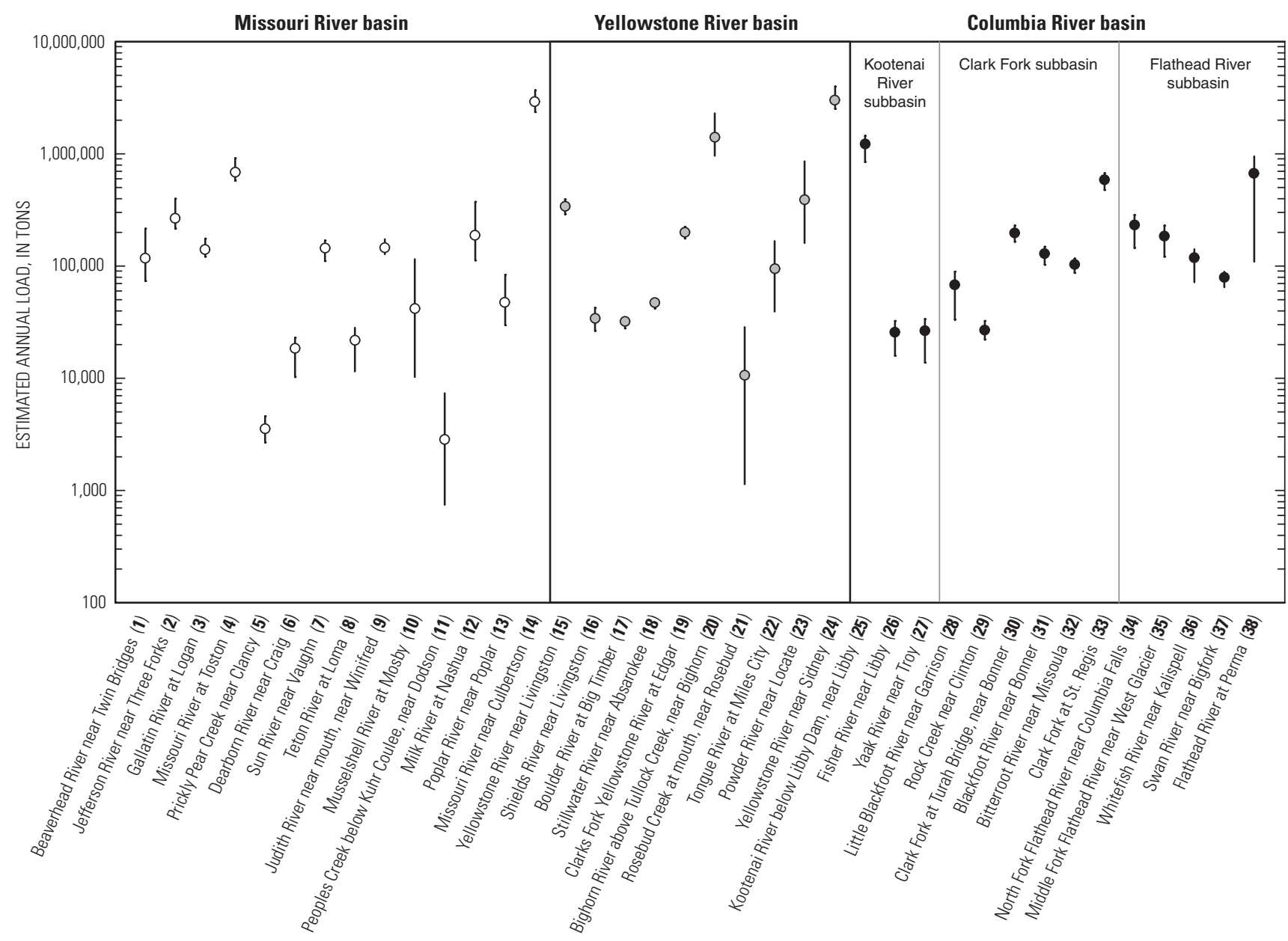

EXPLANATION

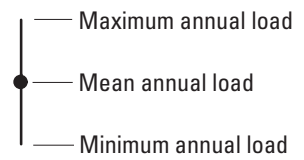

Figure 25. Range and mean of estimated annual loads of dissolved solids at network sites in Montana, water years 1999-2003. Site number presented after station name (fig. 1, table 1).

that exceeded 100,000 tons were transported past Sun River near Vaughn, Judith River near Winifred, and Milk River at Nashua. The loads from each of these tributaries generally were in proportion to their streamflow contributions of about 3-5 percent.

In the Yellowstone River basin, mean annual loads of dissolved solids ranged from 10,600 tons at Rosebud Creek near Rosebud to 2,970,000 tons at Yellowstone River near Sidney. Annual loads of dissolved solids for individual years during 1999-2003 ranged from 1,140 tons at Rosebud Creek near Rosebud to 4,000,000 tons at Yellowstone River near Sidney (fig. 25, table 10). The largest variation in annual loads occurred at Rosebud Creek near Rosebud, where the smallest annual load was only about 4 percent of the largest load. The smallest variation in annual loads occurred at Boulder River at Big Timber, where the smallest annual load was about 96 percent of the largest load.

The combined mean annual load of dissolved solids (2,550,000 tons) for the Yellowstone River near Livingston plus the downstream sampled tributaries accounted for about 86 percent of the mean annual load at Yellowstone River near Sidney $(2,970,000$ tons). Therefore, the sampled upstream source areas in the Yellowstone River basin (which account for essentially all of the streamflow, table 4) accounted for most 
of the load of dissolved solids at the Yellowstone River near Sidney. The largest mean annual load of dissolved solids from upstream sources was transported past Bighorn River near Bighorn (1,410,000 tons), which accounted for about 47 percent of the mean annual load at Yellowstone River near Sidney (table 10). The mean annual load from the Bighorn River was proportionally large relative to the mean annual streamflow contribution of about 31 percent (table 4). Other large mean annual loads of dissolved solids that exceeded 300,000 tons were transported past Yellowstone River near Livingston and Powder River near Locate. The loads at these two sites represented similar percentages (about 11 and 13 percent, respectively) of the load at Yellowstone River near Sidney, but the streamflow contributions relative to load contributions were notably different. Whereas the Yellowstone River near Livingston contributed only a proportionally small amount of dissolved solids (11 percent) relative to its streamflow contribution of about 39 percent, Powder River near Locate contributed a proportionally large amount of dissolved solids (13 percent) relative to its small streamflow contribution of only about 4 percent.

In the Columbia River basin, mean annual loads of dissolved solids ranged from about 26,000 tons at Fisher River near Libby to 1,230,000 tons at Kootenai River below Libby Dam. Annual loads of dissolved solids for individual years during 1999-2003 ranged from 13,700 tons at Yaak River near Troy to 1,440,000 tons at Kootenai River below Libby Dam (fig. 25, table 10). Most sites in the Columbia River basin displayed only small variation in annual dissolved-solids loads. The largest variation in annual loads occurred at Flathead River at Perma, where the smallest annual load was about 60 percent of the largest load. The smallest variation in annual loads occurred at Bitterroot River near Missoula, where the smallest annual load was about 75 percent of the largest load.

In the Kootenai River portion of the Columbia River basin, the largest mean annual load of dissolved solids (1,230,000 tons) was transported past Kootenai River below Libby Dam (table 10). In the Clark Fork and Flathead River subbasins of the Columbia River basin, the largest mean annual load (946,000 tons) was transported past Flathead River at Perma, which accounted for about 62 percent of the combined mean annual load (1,530,000 tons) of Clark Fork at St. Regis plus Flathead River at Perma. This load contribution from the Flathead River is the same as the streamflow contribution of 62 percent. In the Clark Fork subbasin upstream from St. Regis, the largest mean annual load of dissolved solids (195,000 tons) was transported past Clark Fork at Turah Bridge, which accounted for about 33 percent of the mean annual load (586,000 tons) at Clark Fork at St. Regis. This load contribution is proportionally large relative to the streamflow contribution of about 17 percent. The combined mean annual load (427,000 tons) for Clark Fork at Turah Bridge, Blackfoot River near Bonner, and Bitterroot River near Missoula represented about 73 percent of the mean annual load (586,000 tons) at Clark Fork at St. Regis. The combined loads are proportional to the combined streamflow contribu- tion of about 73 percent. The nearly identical proportionality between the relative contributions of dissolved-solids loads and streamflow at sites in the Columbia River basin indicates that streamflow magnitude predominates the load calculations, which typically happens when concentrations are low and generally constant (fig. 12).

\section{Trace Elements}

Trace elements were analyzed at a frequency of only two times per year. Consequently, the small number of samples collected during the monitoring period limits the extent of seasonal and hydrologic characterization available for developing regression relations. In addition, a large percentage of traceelement concentrations (table 15) were less than the LRL, which further restricts characterization of how trace-element discharge varies with streamflow. Annual loads were estimated for only two of the trace elements analyzed (total-recoverable arsenic and copper), which occurred at concentrations greater than the LRL in most samples from one or more of the major river basins. For several sites, the data were only marginally adequate for load estimation. Therefore, it is emphasized that the estimated loads are presented primarily for relative comparisons between sites and do not necessarily represent quantitative estimates.

\section{Total-Recoverable Arsenic}

Total-recoverable arsenic concentrations greater than the LRL were measured more frequently in samples from the Missouri River basin than in samples from the other two basins. For most sites in the Missouri River basin, the same type of regression analysis was used to estimate annual loads as was used for other constituent loads; however, samples from several sites had consistently uniform concentrations (typically less than the LRL or varied by no more than several micrograms per liter) over the range of flow conditions that were sampled. Where concentrations are nearly constant, the load is essentially controlled by the magnitude of the streamflow and differences in annual loads between sites primarily reflect differences in flow. At those sites where concentrations were consistently uniform, an alternate method of load estimation was used. The daily mean streamflows were multiplied by the mean concentration determined from the periodic samples (table 15) and a units conversion constant to compute daily loads of total recoverable arsenic.

Arsenic concentrations less than the LRL were common at sites in the Yellowstone River basin. Typically, these low concentrations preclude annual load calculations; however, to provide a complete set of estimated annual loads for arsenic at all sites in the Yellowstone River basin, generalized estimates of loads for sites where regression relations were not statistically significant were calculated using the alternate method of load estimation. Where mean concentrations were less than the LRL, a value equal to one-half the LRL was used. Generalized estimates of total-recoverable arsenic loads are presented 
primarily for relative comparisons between sites and do not necessarily represent quantitative estimates (table 11). The excessively large number of arsenic concentrations less than the LRL at most sites in the Columbia River basin precludes even a gross estimation of arsenic loads.
Equations for estimating daily loads of total-recoverable arsenic at network sites are presented in table 11, along with the range and means of estimated annual loads during water years 1999-2003. For some sites, the data were transformed to either logarithms or square roots to achieve the best linear fit to the regression line; equations for these sites were all

Table 11. Equations for estimating daily loads of total-recoverable arsenic and summaries of the range and mean of estimated annual loads at network sites in Montana, water years 1999-2003.

[For the Columbia River basin, most sites had an insufficient number of samples with concentrations greater than the laboratory reporting level to develop equations for estimating daily loads. Abbreviations: $\mathrm{R}^{2}$, coefficient of determination; $\mathrm{p}$, significance level; SE, standard error, in percent; ASQ, total-recoverable arsenic discharge, in tons per day; Q, daily mean streamflow, in cubic feet per second. Symbols: <, less than; --, regression equation not significant at $\mathrm{p}=0.05]$

\begin{tabular}{|c|c|c|c|c|c|c|c|}
\hline \multirow{2}{*}{$\begin{array}{c}\text { Site } \\
\text { number } \\
\text { (fig. 1) }\end{array}$} & \multirow{2}{*}{ Station name } & \multirow{2}{*}{ Equation } & \multicolumn{3}{|c|}{ Regression statistics } & \multirow{2}{*}{$\begin{array}{c}\text { Range of } \\
\text { estimated } \\
\text { annual } \\
\text { loads } \\
\text { (tons) }\end{array}$} & \multirow{2}{*}{$\begin{array}{c}\text { Mean of } \\
\text { estimated } \\
\text { annual } \\
\text { loads } \\
\text { (tons) }\end{array}$} \\
\hline & & & $\mathbf{R}^{2}$ & p & SE & & \\
\hline \multicolumn{8}{|c|}{ Missouri River basin } \\
\hline 2 & Jefferson River near Three Forks & $\mathrm{ASQ}=0.00000807(\mathrm{Q})^{1.07}$ & .90 & $<.0001$ & 49 & $5.06-12.3$ & 7.22 \\
\hline 3 & Gallatin River at Logan & $\mathrm{ASQ}=0.000000449(\mathrm{Q})^{1.32}$ & .87 & .0002 & 62 & $.94-2.00$ & 1.36 \\
\hline 4 & Missouri River at Toston & $\mathrm{ASQ}=0.000933(\mathrm{Q})^{0.705}$ & .92 & $<.0001$ & 18 & 95.4-141 & 109 \\
\hline 8 & Teton River at Loma ${ }^{3}$ & $\mathrm{ASQ}=0.000000302(\mathrm{Q})^{1.73}$ & .93 & $<.0001$ & 72 & $.04-.37$ & .15 \\
\hline 9 & Judith River near mouth, near Winifred ${ }^{1,3}$ & $\mathrm{ASQ}=0.000000224(\mathrm{Q})^{1.56}$ & .98 & .0001 & 20 & $.45-1.10$ & .41 \\
\hline 10 & Musselshell River at Mosby ${ }^{3}$ & $\mathrm{ASQ}=0.00000550(\mathrm{Q})^{1.05}$ & .95 & $<.0001$ & 81 & $.02-.22$ & .08 \\
\hline 11 & $\begin{array}{l}\text { Peoples Creek below Kuhr Coulee, near } \\
\text { Dodson }\end{array}$ & $\mathrm{ASQ}=0.00000676(\mathrm{Q})^{0.904}$ & .99 & $<.0001$ & 37 & $<.01-.02$ & .01 \\
\hline 12 & Milk River at Nashua & $\mathrm{ASQ}=0.00000174(\mathrm{Q})^{1.38}$ & .88 & $<.0001$ & 99 & $1.28-9.42$ & 3.35 \\
\hline 13 & Poplar River near Poplar & $\mathrm{ASQ}=0.0000115(\mathrm{Q})^{0.884}$ & .95 & $<.0001$ & 36 & $.09-.44$ & .20 \\
\hline 16 & Shields River near Livingston ${ }^{2}$ & $\mathrm{ASQ}=1.5(\mathrm{Q}) 0.0000027$ & -- & -- & -- & $.17-.40$ & .25 \\
\hline 17 & Boulder River at Big Timber ${ }^{2}$ & $\mathrm{ASQ}=1(\mathrm{Q}) 0.0000027$ & -- & -- & -- & $.31-.52$ & .41 \\
\hline 18 & Stillwater River near Absarokee ${ }^{1,2}$ & $\mathrm{ASQ}=1(\mathrm{Q}) 0.0000027$ & -- & -- & -- & $.56-.80$ & .70 \\
\hline 19 & Clarks Fork Yellowstone River at Edgar ${ }^{2}$ & $\mathrm{ASQ}=1.5(\mathrm{Q}) 0.0000027$ & -- & -- & -- & $.95-1.68$ & 1.33 \\
\hline 20 & $\begin{array}{l}\text { Bighorn River above Tullock Creek, } \\
\text { near Bighorn }{ }^{2}\end{array}$ & $\mathrm{ASQ}=1.5(\mathrm{Q}) 0.0000027$ & -- & -- & -- & $2.20-8.04$ & 4.01 \\
\hline
\end{tabular}


Table 11. Equations for estimating daily loads of total-recoverable arsenic and summaries of the range and mean of estimated annual loads at network sites in Montana, water years 1999-2003.-Continued

\begin{tabular}{|c|c|c|c|c|c|c|c|}
\hline \multirow{2}{*}{$\begin{array}{c}\text { Site } \\
\text { number } \\
\text { (fig. 1) }\end{array}$} & \multirow{2}{*}{ Station name } & \multirow{2}{*}{ Equation } & \multicolumn{3}{|c|}{ Regression statistics } & \multirow{2}{*}{$\begin{array}{c}\text { Range of } \\
\text { estimated } \\
\text { annual } \\
\text { Ioads } \\
\text { (tons) }\end{array}$} & \multirow{2}{*}{$\begin{array}{c}\text { Mean of } \\
\text { estimated } \\
\text { annual } \\
\text { loads } \\
\text { (tons) }\end{array}$} \\
\hline & & & $\mathbf{R}^{2}$ & $\mathbf{p}$ & SE & & \\
\hline \multicolumn{8}{|c|}{ Yellowstone River basin-Continued } \\
\hline 22 & Tongue River at Miles City ${ }^{3}$ & $\mathrm{ASQ}=0.00000295(\mathrm{Q})^{1.12}$ & .94 & $<.0001$ & 48 & $.12-1.21$ & .55 \\
\hline 23 & Powder River near Locate & $\mathrm{ASQ}=0.00000186(\mathrm{Q})^{1.34}$ & .93 & $<.0001$ & 105 & $.54-6.68$ & 2.29 \\
\hline 24 & Yellowstone River near Sidney & $\mathrm{ASQ}=0.00000479(\mathrm{Q})^{1.16}$ & .95 & $<.0001$ & 25 & $46.7-113$ & 67.7 \\
\hline 33 & Clark Fork at St. Regis & $\mathrm{ASQ}=0.00000355(\mathrm{Q})^{1.02}$ & .86 & $<.0001$ & 53 & $6.50-12.0$ & 9.53 \\
\hline
\end{tabular}

${ }^{1}$ Less than 5 years of either sample data or daily mean streamflow record were available for load calculations.

${ }^{2}$ Daily loads were calculated by multiplying the mean concentration (table 15) determined from periodic samples by the daily mean streamflow and units conversion constant.

${ }^{3}$ More than 25 percent of the analytical values used for load calculations are less than the laboratory reporting level.

highly significant $(\mathrm{p}<0.0001)$. At other sites, the mean concentration from periodic samples (table 15) and daily mean streamflow was used (table 11). The range and mean of estimated annual loads of total-recoverable arsenic above are shown in figure 26. Across the network, the means of the estimated annual loads of total-recoverable arsenic ranged from 0.01 to 109 tons (table 11 ).

In the Missouri River basin, mean annual loads of totalrecoverable arsenic ranged from 0.01 ton at Peoples Creek near Dodson to 109 tons at Missouri River at Toston. Annual loads of arsenic for individual years during 1999-2003 ranged from less than 0.01 ton at Peoples Creek near Dodson to 141 tons at Missouri River at Toston (fig. 26, table 11). The mean annual load at Missouri River at Toston (109 tons) was much larger than at any of the other sites in the Missouri River basin. The combined mean annual load of arsenic (8.58 tons) contributed by the Jefferson and Gallatin Rivers accounted for only about 8 percent of the arsenic load at Missouri River at Toston; consequently, most (92 percent) of the arsenic load originates in the Madison River basin. Although this headwater tributary was not sampled as part of the statewide network, a study by Nimick and others (1998) has shown that the Madison River transports a large quantity of arsenic that is derived from geothermal sources within Yellowstone National Park.
Arsenic transport is generally conservative in the upper part of the Missouri River basin, but becomes non-conservative in the lower part of the basin where suspended-sediment concentrations increase; suspended sediment provides sorption sites for dissolved arsenic, which binds to the sediment particles (Nimick and others, 1998). After sorbing to sediment, a substantial portion of the arsenic load likely settles out in the mainstem reservoirs. The combined mean annual load (114 tons) at the Missouri River at Toston plus the downstream sampled tributaries was greater than the mean annual load (40.2 tons) at Missouri River at Culbertson showing that about 65 percent of the arsenic load contributed to the Missouri River mainstem was deposited before reaching Culbertson. Tributaries downstream from Missouri River at Toston added only 5.24 tons of arsenic (table 11), indicating that these tributary basins are not a substantial source of arsenic relative to the Madison River. The approximately 74 tons of arsenic deposited annually in the bottom sediments of mainstem reservoirs could possibly represent a significant source of arsenic if geochemical processes occurred that mobilized arsenic back into solution in the water column or local ground water.

In the Yellowstone River basin, mean annual loads of total-recoverable arsenic ranged from 0.04 ton at Rosebud Creek near Rosebud to 67.7 tons at Yellowstone River near Sidney. Annual loads of arsenic for individual years during 1999-2003 ranged from less than 0.01 ton at Rosebud Creek 
near Rosebud to 113 tons at Yellowstone River near Sidney (fig. 26, table 11). The combined mean annual arsenic load (71.7 tons) of Yellowstone River near Livingston plus sampled tributaries downstream from Livingston was within 6 percent of the mean annual load (67.7 tons) at Yellowstone River near Sidney, indicating that arsenic transport in the absence of mainstem reservoirs is generally conservative in the Yellowstone River basin.

The largest mean annual load of arsenic from upstream sources was transported past Yellowstone River near Livingston (62.1 tons), which accounted for about 92 percent of the mean annual load (67.7 tons) at Yellowstone River near Sidney. This high percentage indicates that downstream tributaries are not a substantial source of arsenic relative to the source area upstream from Livingston. Similar to the Missouri River basin, most of the arsenic presumably originates from geothermal sources in Yellowstone National Park.

In the Columbia River basin, only three sites in the Clark Fork subbasin (Little Blackfoot River near Garrison, Clark Fork at Turah Bridge, and Clark Fork at St. Regis) had adequate data to develop regression equations for estimating total-recoverable arsenic loads. Alternate methods were not used at the other sites to estimate annual loads due to an excessive number of concentrations less than the LRL. Mean annual loads of total-recoverable arsenic for the three sites in the Clark Fork subbasin ranged from 0.65 ton at Little Blackfoot River near Garrison to 9.53 tons at Clark Fork at St. Regis. Annual loads of arsenic for individual years during 1999-2003

\section{TOTAL-RECOVERABLE ARSENIC}

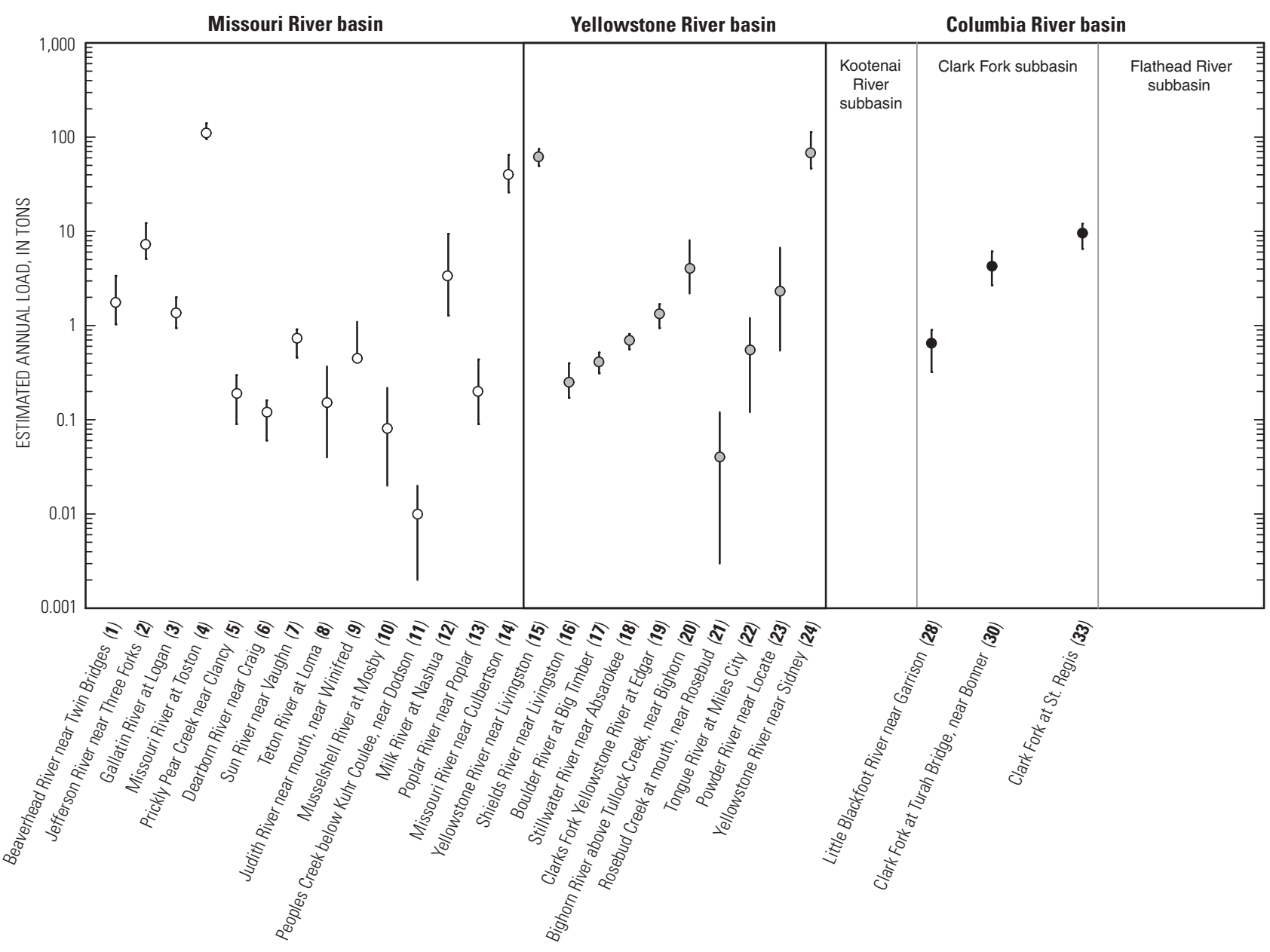

EXPLANATION

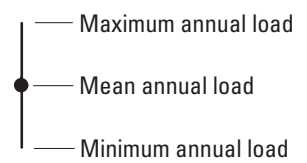

Figure 26. Range and mean of estimated annual loads of total-recoverable arsenic at network sites in Montana, water years 1999-2003. Site number presented after station name (fig. 1, table 1). 
ranged from 0.32 ton at Little Blackfoot River near Garrison to 12.0 tons at Clark Fork at St. Regis (fig. 26, table 11). In the Clark Fork subbasin upstream from St. Regis, the mean annual load (4.33 tons) transported past Clark Fork at Turah Bridge accounted for about 45 percent of the mean annual load (9.53 tons) at Clark Fork at St. Regis (table 11). The mean annual load at Clark Fork at Turah Bridge was proportionally large relative to the streamflow contribution of only 17 percent (table 4).

\section{Total-Recoverable Copper}

Equations for estimating daily loads of total-recoverable copper at network sites are presented in table 12, along with the range and mean of estimated annual loads during water years 1999-2003. The data were transformed to either logarithms or square roots prior to regression analysis to achieve the best linear fit to the regression line. All equations were statistically significant (range of p-values from $<0.0001$ to 0.0221 ). Values of $\mathrm{R}^{2}$ ranged from 0.55 to 0.99 , indicating that the accuracy of annual load estimates may vary substantially between sites. In the Columbia River basin, the annual loads for Swan River near Bigfork were estimated by the alternate method of multiplication of the mean total-recoverable copper concentration (table 15) by daily mean streamflows because total-recoverable copper concentrations were consistently uniform. The range and mean of estimated annual loads of total-recoverable copper are presented in figure 27. Across the network, the means of the estimated annual loads of totalrecoverable copper ranged from 0.02 to 80.9 tons (table 12).

In the Missouri River basin, mean annual loads of totalrecoverable copper ranged from 0.02 ton at Peoples Creek near Dodson to 54.9 tons at Missouri River near Culbertson. Annual loads of copper for individual years during 1999-2003 ranged from less than 0.01 ton at Peoples Creek near Dodson to 85.6 tons at Missouri River near Culbertson (fig. 27, table 12). Unlike the small combined mean annual arsenic load (about 8 percent) contributed to the Missouri River at Toston by the Jefferson and Gallatin Rivers, the combined mean annual copper load from these two streams (9.67 tons) represented about 71 percent of the mean annual load (13.6 tons) at Missouri River at Toston.

Only about 46 percent of the mean annual load of copper (54.9 tons) at Missouri River near Culbertson can be accounted for by the combined load (25.5 tons) for Missouri River at Toston plus the sampled tributaries downstream from Toston. The proportionally smaller mean annual load contribution (46 percent) relative to the combined mean annual streamflow contribution of 62 percent (table 4) might indicate that copper is deposited in the mainstem reservoirs. Similar to several other constituents, the relatively small percentage of the load at Missouri River near Culbertson that is accounted for by upstream source areas sampled in the network indicates the presence of substantial, unmeasured sources of totalrecoverable copper. The largest mean annual copper load from upstream sources was transported past Missouri River at Tos- ton (13.6 tons), which accounted for about 25 percent of the mean annual load at Missouri River near Culbertson. This load was proportionally small relative to the streamflow contribution of about 46 percent. The next largest load of copper from upstream sources was transported past Milk River at Nashua (7.82 tons), which accounted for about 14 percent of the mean annual load at Missouri River near Culbertson. The load from the Milk River was proportionally large relative to the streamflow contribution of only about 4 percent.

In the Yellowstone River basin, mean annual loads of total-recoverable copper ranged from 0.27 ton at Rosebud Creek near Rosebud to 80.9 tons at Yellowstone River near Sidney. Annual loads of copper for individual years during 1999-2003 ranged from 0.02 ton at Rosebud Creek near Rosebud to 154 tons at Yellowstone River near Sidney (fig. 27, table 12).

The combined mean annual load of copper (63.2 tons) at Yellowstone River near Livingston plus the downstream sampled tributaries accounted for about 78 percent of the mean annual load (80.9 tons) at Yellowstone River near Sidney. The largest mean annual copper load from upstream sources was transported past Yellowstone River near Livingston (18.8 tons), which accounted for about 23 percent of the mean annual load at Yellowstone River near Sidney. The load at Yellowstone River near Livingston was proportionally small relative to the streamflow contribution of about 39 percent (table 4). The next largest copper load from upstream sources was transported past Clarks Fork Yellowstone River at Edgar (16.4 tons), which accounted for about 20 percent of the load at Yellowstone River near Sidney. The copper load from the Clarks Fork Yellowstone River was proportionally about double the streamflow contribution of about 10 percent. Other relatively large copper loads of more than 10 tons were transported past Bighorn River near Bighorn (10.7 tons) and Powder River near Locate (11.7 tons), which represented about 13 and 14 percent, respectively, of the copper load at Yellowstone River near Sidney. The copper load from the Bighorn River was proportionally small (13 percent) relative to its streamflow contribution (about 31 percent), whereas the copper load from the Powder River was proportionally high (14 percent) relative to its streamflow contribution (about 4 percent).

In the Columbia River basin, mean annual loads of total-recoverable copper ranged from 0.09 ton at Yaak River near Troy to the nearly equal loads of 34.2 tons at Clark Fork at St. Regis and 34.8 tons at Flathead River at Perma. However, the regression relation for Flathead River at Perma was relatively poor $\left(\mathrm{p}=0.0221, \mathrm{R}^{2}=0.55\right)$ and analytical results from eight samples collected in 1999 and 2000 were not used in the regression analysis because they were censored at a high LRL. Thus, the estimated copper loads for Flathead River near Perma may have substantial error. Annual copper loads for individual years during 1999-2003 ranged from 0.03 ton at the Yaak River near Troy to 50.7 tons at the Clark Fork at St. Regis (fig. 27, table 12). Annual copper loads in the Columbia River basin generally varied less than in the Missouri or Yellowstone River basins. 
Table 12. Equations for estimating daily loads of total-recoverable copper and summaries of the range and mean of estimated annual loads at network sites in Montana, water years 1999-2003.

[Abbreviations: $\mathrm{R}^{2}$, coefficient of determination; $\mathrm{p}$, significance level; SE, standard error, in percent; CUQ, total-recoverable copper discharge, in tons per day; Q, streamflow in cubic feet per second; LOGCUQ, logarithm (base 10) of total recoverable copper discharge, in tons per day. Symbols: <, less than; --, no data]

\begin{tabular}{|c|c|c|c|c|c|c|c|}
\hline \multirow{2}{*}{$\begin{array}{c}\text { Site } \\
\text { number } \\
\text { (fig. 1) }\end{array}$} & \multirow{2}{*}{ Station name } & \multirow{2}{*}{ Equation } & \multicolumn{3}{|c|}{ Regression statistics } & \multirow{2}{*}{$\begin{array}{c}\text { Range of } \\
\text { estimated } \\
\text { annual } \\
\text { loads } \\
\text { (tons) }\end{array}$} & \multirow{2}{*}{$\begin{array}{c}\text { Mean of } \\
\text { estimated } \\
\text { annual } \\
\text { loads } \\
\text { (tons) }\end{array}$} \\
\hline & & & $\mathbf{R}^{2}$ & p & SE & & \\
\hline \multicolumn{8}{|c|}{ Missouri River basin } \\
\hline 2 & Jefferson River near Three Forks & $\mathrm{CUQ}=0.000000155(\mathrm{Q})^{1.58}$ & .85 & .0001 & 104 & $3.75-15.5$ & 7.33 \\
\hline 3 & Gallatin River at Logan & $\mathrm{CUQ}=0.00000000933(\mathrm{Q})^{1.93}$ & .92 & $<.0001$ & 69 & $1.13-3.98$ & 2.34 \\
\hline 4 & Missouri River at Toston & CUQ $=0.0000000933(Q)^{1.55}$ & .85 & .0001 & 64 & $8.90-23.9$ & 13.6 \\
\hline 8 & Teton River at Loma & $\mathrm{CUQ}=0.00000162(\mathrm{Q})^{1.57}$ & .90 & .0001 & 81 & $.10-.70$ & .32 \\
\hline 9 & Judith River near mouth, near Winifred ${ }^{1}$ & $\mathrm{CUQ}=0.00000112(\mathrm{Q})^{1.39}$ & .91 & .0033 & 41 & $.87-1.69$ & 1.16 \\
\hline 10 & Musselshell River at Mosby & $\mathrm{CUQ}=0.0000204(\mathrm{Q})^{0.937}$ & .87 & .0002 & 139 & $.04-.75$ & .17 \\
\hline 11 & $\begin{array}{l}\text { Peoples Creek below Kuhr Coulee, near } \\
\text { Dodson }\end{array}$ & $\mathrm{CUQ}=0.000000813(\mathrm{Q})^{1.11}$ & .95 & $<.0001$ & 110 & $<.01-.05$ & .02 \\
\hline 12 & Milk River at Nashua & $\mathrm{CUQ}=0.00000151(\mathrm{Q})^{1.51}$ & .92 & $<.0001$ & 82 & $4.31-23.2$ & 7.82 \\
\hline 13 & Poplar River near Poplar & $\mathrm{CUQ}=0.00000417(\mathrm{Q})^{1.24}$ & .94 & $<.0001$ & 62 & $.14-2.33$ & .72 \\
\hline 17 & Boulder River at Big Timber & $\mathrm{CUQ}=0.000000219(\mathrm{Q})^{1.48}$ & .94 & $<.0001$ & 72 & $.68-1.49$ & 1.09 \\
\hline 18 & Stillwater River near Absarokee ${ }^{1}$ & CUQ $=0.0000000661(Q)^{1.62}$ & .96 & $<.0001$ & 46 & $1.04-2.00$ & 1.70 \\
\hline 19 & Clarks Fork Yellowstone River at Edgar & LOGCUQ $=-3.44+0.0432(\mathrm{Q})^{0.5}$ & .97 & $<.0001$ & 39 & $4.05-25.8$ & 16.4 \\
\hline 20 & $\begin{array}{l}\text { Bighorn River above Tullock Creek, } \\
\text { near Bighorn }\end{array}$ & $\mathrm{CUQ}=0.0000200(\mathrm{Q})^{0.924}$ & .76 & .001 & 35 & $6.20-20.6$ & 10.7 \\
\hline 21 & Rosebud Creek at mouth, near Rosebud & $\mathrm{CUQ}=0.0000162(\mathrm{Q})^{1.33}$ & .87 & .0002 & 226 & $.02-.85$ & .27 \\
\hline 22 & Tongue River at Miles City & $\mathrm{CUQ}=0.0000110(\mathrm{Q})^{1.09}$ & .86 & .0003 & 106 & $.41-3.68$ & 1.70 \\
\hline 23 & Powder River near Locate & $\mathrm{CUQ}=0.00000832(\mathrm{Q})^{1.36}$ & 90 & $<.0001$ & 147 & $2.70-34.6$ & 11.7 \\
\hline 24 & Yellowstone River near Sidney & $\mathrm{CUQ}=0.000000125(\mathrm{Q})^{1.56}$ & .82 & $<.0001$ & 205 & $45.0-154$ & 80.9 \\
\hline
\end{tabular}


Table 12. Equations for estimating daily loads of total-recoverable copper and summaries of the range and mean of estimated annual loads at network sites in Montana, water years 1999-2003.—Continued

\begin{tabular}{|c|c|c|c|c|c|c|c|}
\hline \multirow{2}{*}{$\begin{array}{c}\text { Site } \\
\text { number } \\
\text { (fig. 1) }\end{array}$} & \multirow{2}{*}{ Station name } & \multirow{2}{*}{ Equation } & \multicolumn{3}{|c|}{ Regression statistics } & \multirow{2}{*}{$\begin{array}{c}\text { Range of } \\
\text { estimated } \\
\text { annual } \\
\text { loads } \\
\text { (tons) }\end{array}$} & \multirow{2}{*}{$\begin{array}{c}\text { Mean of } \\
\text { estimated } \\
\text { annual } \\
\text { loads } \\
\text { (tons) }\end{array}$} \\
\hline & & & $\mathbf{R}^{2}$ & p & SE & & \\
\hline \multicolumn{8}{|c|}{ Columbia River basin } \\
\hline 26 & Fisher River near Libby & $\mathrm{CUQ}=0.0000000812(\mathrm{Q})^{1.62}$ & .95 & $<.0001$ & 48 & $.40-1.64$ & .86 \\
\hline 27 & Yaak River near Troy & $\mathrm{CUQ}=0.0000000812(\mathrm{Q})^{1.62}$ & .93 & $<.0001$ & 53 & $.03-.14$ & .09 \\
\hline 28 & Little Blackfoot River near Garrison & $\mathrm{CUQ}=0.000000891(\mathrm{Q})^{1.36}$ & .95 & $<.0001$ & 39 & $.09-.40$ & .24 \\
\hline 31 & Blackfoot River near Bonner & $\mathrm{CUQ}=0.0000000109(\mathrm{Q})^{1.78}$ & .94 & $<.0001$ & 50 & $1.26-3.77$ & 2.62 \\
\hline 32 & Bitterroot River near Missoula & $\mathrm{CUQ}=0.00000000977(\mathrm{Q})^{1.78}$ & .96 & $<.0001$ & 46 & $2.56-8.14$ & 5.81 \\
\hline 33 & Clark Fork at St. Regis & $\mathrm{CUQ}=0.0000000105(\mathrm{Q})^{1.77}$ & .95 & $<.0001$ & 46 & $14.8-50.7$ & 34.2 \\
\hline 34 & $\begin{array}{l}\text { North Fork Flathead River near } \\
\text { Columbia Falls }\end{array}$ & $\mathrm{CUQ}=0.0000000135(\mathrm{Q})^{1.73}$ & .90 & $<.0001$ & 82 & $3.18-14.4$ & 8.31 \\
\hline 35 & $\begin{array}{l}\text { Middle Fork Flathead River near West } \\
\text { Glacier }^{2}\end{array}$ & $\mathrm{CUQ}=0.0000000229(\mathrm{Q})^{1.65}$ & .95 & $<.0001$ & 54 & $3.34-10.7$ & 6.58 \\
\hline
\end{tabular}

${ }^{1}$ Less than 5 years of either sample data or daily mean streamflow record were available for load calculations.

${ }^{2}$ More than 25 percent of the analytical values used for load calculations are less than the laboratory reporting level.

${ }^{3}$ Daily loads were calculated by multiplying the mean concentration (table 15) determined from periodic samples by daily mean streamflow and units conversion constant.

${ }^{4}$ Analytical results for several samples from 1999 and 2000 that were censored at high laboratory reporting levels were not used in regression analysis.

In the Kootenai River subbasin of the Columbia River basin, the largest annual load of copper (10.7 tons) was transported past Kootenai River below Libby Dam. In the Clark Fork and Flathead River subbasins of the Columbia River basin, the combined mean annual load (69.0 tons) for Clark Fork at St. Regis plus Flathead River at Perma was contributed in nearly equal amounts by each river (34.2 and 34.8 tons, respectively). The copper load from the Clark Fork at St. Regis of about 50 percent of the combined load was proportionally large compared to the streamflow contribution of about
38 percent (table 4). In the Clark Fork subbasin upstream from St. Regis, the largest mean annual load of copper (17.7 tons) was transported past Clark Fork at Turah Bridge, which was about 3-7 times larger than the mean annual loads contributed by the Blackfoot (2.62 tons) and Bitterroot Rivers (5.81 tons), and represented about 52 percent of the mean annual load at Clark Fork at St. Regis. The copper load at Clark Fork at Turah Bridge was proportionally much larger than the streamflow contribution of 17 percent. The combined mean annual load of copper (26.1 tons) for Clark Fork at Turah Bridge, 
TOTAL-RECOVERABLE COPPER
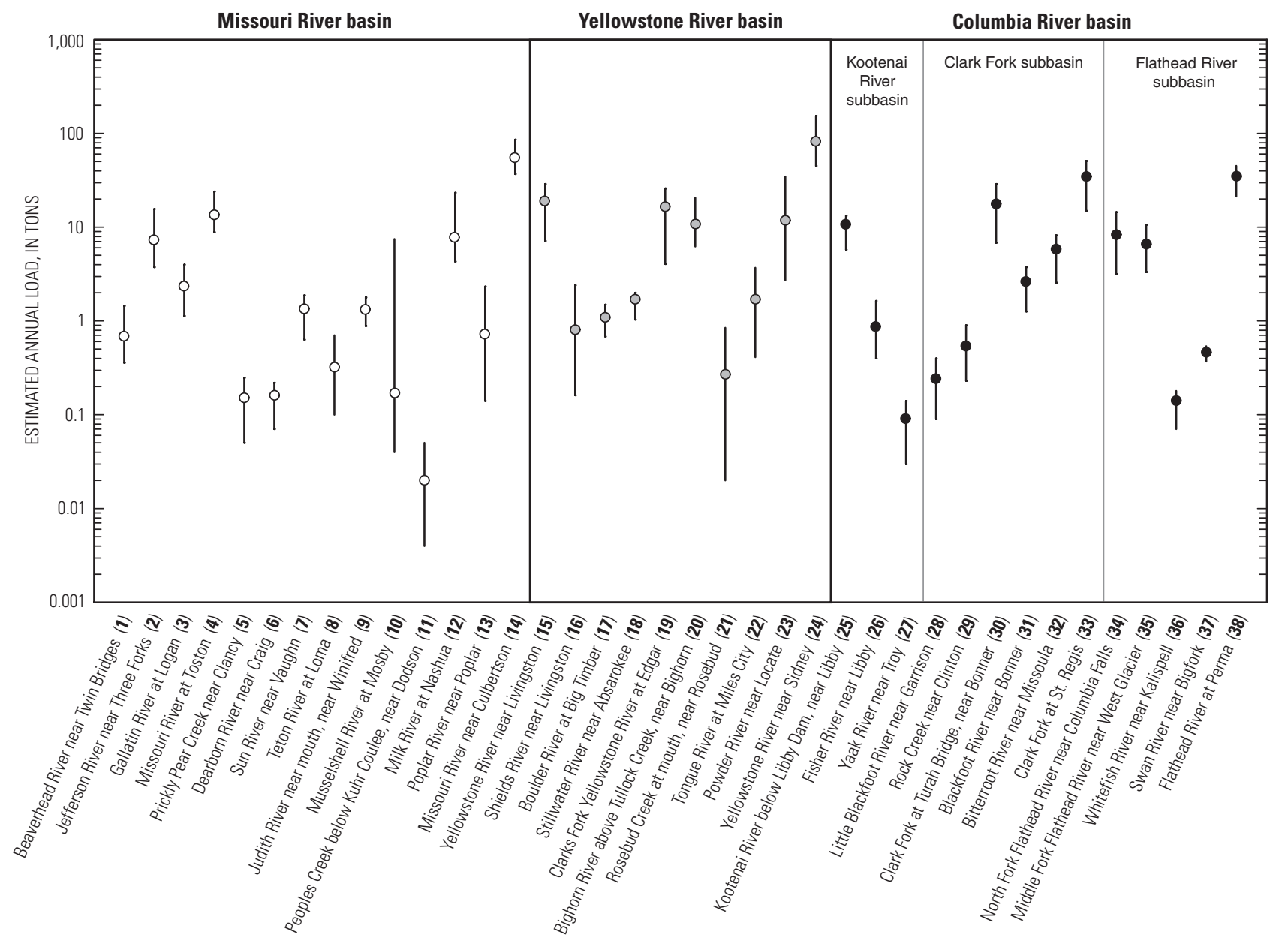

EXPLANATION

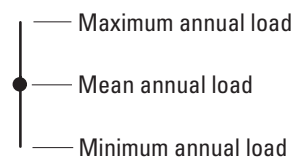

Figure 27. Range and mean of estimated annual loads of total-recoverable copper at network sites in Montana, water years 1999-2003. Site number presented after station name (fig. 1, table 1).

Blackfoot River near Bonner, and Bitterroot River near Missoula accounted for about 76 percent of the mean annual load (34.2 tons) at Clark Fork at St. Regis. The combined loads are closely proportional to the combined streamflow contribution of about 73 percent (table 4), indicating that the copper loads from the Blackfoot and Bitterroot Rivers are proportionally small relative to their streamflow contributions.

\section{Summary and Conclusions}

A statewide monitoring network of 38 sites was established in May 1999 by the U.S. Geological Survey (USGS), in cooperation with the Montana Department of Environmental Quality (MDEQ), to address the State's need for a general characterization of water quality in Montana streams. The sites were distributed within the Missouri, Yellowstone, and Columbia River basins and were located at active USGS streamflowgaging stations. Samples were collected four times per year for selected stream properties, nutrients, and suspended sediment. Major ions and selected trace elements were analyzed two times per year. A subset of 26 sites also had continuous water-temperature monitors that were operated during the 
warm-weather season (typically April through September). Data collected during the 5-year monitoring period of water years 1999-2003 were statistically summarized to describe general water-quality conditions and illustrate relative differences among sites. In addition, annual loads were estimated for selected constituents to allow relative comparison of input from various source areas.

Mean annual streamflows during water years 1999-2003 were below normal compared to long-term periods of record, ranging from about 12 percent at Musselshell River at Mosby to 91 percent at Kootenai River below Libby Dam. Streamflows at sites in the Missouri River basin were the most depleted relative to long-term conditions; sites in the Columbia River basin were the least affected. Peak flows in the Missouri River and Yellowstone River basins during 1999-2003 generally occurred earlier in the year and were substantially less in magnitude and duration than long-term peak flows; peak flows in the Columbia River basin were more similar to long-term conditions. The less-than-normal streamflow presumably affected both constituent concentrations and annual loads.

The $\mathrm{pH}$ values across the State ranged from 7.0 to 9.5, with almost every site having a median $\mathrm{pH}$ greater than 8.0. Only two sites in the Columbia River basin had a median $\mathrm{pH}$ less than 8.0 (Yaak River near Troy and Bitterroot River near Missoula). Extremely high or low $\mathrm{pH}$ was not consistently measured at any site.

Specific conductance varied widely across the network, ranging from $32 \mu \mathrm{S} / \mathrm{cm}$ at Yaak River near Troy to $6,940 \mu \mathrm{S} / \mathrm{cm}$ at Musselshell River at Mosby. Median specific conductance ranged from $76 \mu \mathrm{S} / \mathrm{cm}$ at Yaak River near Troy to 2,480 $\mathrm{SS} / \mathrm{cm}$ at Musselshell River at Mosby. Rosebud Creek near Rosebud and Powder River near Locate also had relatively high specific conductance values, with both sites having medians near 2,000 $\mu \mathrm{S} / \mathrm{cm}$. Samples from several sites across the network had specific conductance that occasionally exceeded the general irrigation guideline of $1,500 \mu \mathrm{S} / \mathrm{cm}$; more than 50 percent of the samples from Musselshell River at Mosby, Rosebud Creek near Rosebud, and Powder River near Locate exceeded the general guideline. The State of Montana numeric standard for the Powder River mainstem $(2,500 \mu \mathrm{S} / \mathrm{cm})$ is substantially higher than the general irrigation guideline; thus, fewer than 25 percent of the samples from Powder River near Locate exceeded the standard.

Daily mean water temperatures for the 3-month summer period (June, July, and August) varied widely at the 26 sites with continuous temperature monitors, ranging from $4.0^{\circ} \mathrm{C}$ at Yaak River near Troy to $29.5^{\circ} \mathrm{C}$ at Teton River at Loma and Tongue River at Miles City. The lowest median $\left(12.5^{\circ} \mathrm{C}\right)$ occurred at Kootenai River below Libby Dam and the highest median $\left(23.0^{\circ} \mathrm{C}\right)$ occurred at Poplar River near Poplar and Tongue River at Miles City. In general, sites in the Columbia River basin had the lowest water temperatures, whereas sites in the Missouri River basin had the highest. Four sites in the Missouri River basin that represent cold-water or cold-water marginal fisheries (Jefferson River near Three Forks, Missouri River at Toston, Judith River near Winifred, and Poplar River near Poplar) had summer daily mean water temperatures that exceeded the general guideline of $67.0^{\circ} \mathrm{F}\left(19.4^{\circ} \mathrm{C}\right)$ for the protection of cold-water aquatic life on 50 percent or more of the days. Three sites in the Missouri River basin (Beaverhead River near Twin Bridges, Gallatin River at Logan, and Dearborn River near Craig) that represent cold-water fisheries exceeded the cold-water guideline on about 25 percent of the days. In the Yellowstone River basin, two sites that represent cold-water marginal fisheries (Clarks Fork Yellowstone River at Edgar and Bighorn River near Bighorn) exceeded the coldwater guideline on about 50 percent of the days. In the Columbia River basin, the cold-water guideline was exceeded on more than 50 percent of the days at Flathead River at Perma and on about 25 percent of the days at Yaak River near Troy, Bitterroot River near Missoula, and Swan River near Bigfork. The warm-water guideline of $80.0^{\circ} \mathrm{F}\left(26.7^{\circ} \mathrm{C}\right)$ was exceeded infrequently across the network.

Dissolved nitrite plus nitrate concentrations across the network ranged from $<0.005 \mathrm{mg} / \mathrm{L}$ as $\mathrm{N}$ at many sites to $3.80 \mathrm{mg} / \mathrm{L}$ as $\mathrm{N}$ at Sun River near Vaughn. None of the sites had samples with concentrations that exceeded the humanhealth standard for nitrate of $10 \mathrm{mg} / \mathrm{L}$ as $\mathrm{N}$. About one-half of the sites in the Missouri and Yellowstone River basins had one or more samples with dissolved nitrite plus nitrate concentrations that exceeded the general eutrophication guideline of $0.30 \mathrm{mg} / \mathrm{L}$. Concentrations of total ammonia plus organic nitrogen varied widely, ranging from $<0.08 \mathrm{mg} / \mathrm{L}$ at many sites to $30 \mathrm{mg} / \mathrm{L}$ at Powder River near Locate. The magnitudes and spatial patterns of total nitrogen concentrations were very similar to those of total ammonia plus organic nitrogen. For nitrogen compounds, concentrations in the Columbia River basin generally were lower than in the Missouri or Yellowstone River basins. The six sites in the Clark Fork subbasin of the Columbia River basin had distinctly higher median concentrations of total ammonia plus organic nitrogen and total nitrogen compared to sites in the Kootenai and Flathead River subbasins. The ecoregion eutrophication guideline of $1.50 \mathrm{mg} / \mathrm{L}$ for total nitrogen was exceeded infrequently at most sites within applicable areas of eastern and central Montana, but was exceeded in more than 25 percent of the samples at Powder River near Locate. The seasonal numeric standards of $0.300 \mathrm{mg} / \mathrm{L}$ for total nitrogen in the Clark Fork mainstem was exceeded in about 25 percent or more of the samples at Clark Fork at Turah Bridge and Clark Fork at St. Regis.

Dissolved orthophosphate concentrations were consistently low across the network, ranging from $<0.001 \mathrm{mg} / \mathrm{L}$ as $\mathrm{P}$ at many sites to $0.158 \mathrm{mg} / \mathrm{L}$ as $\mathrm{P}$ at Peoples Creek near Dodson; standards are not currently (2006) established. Total phosphorus concentrations varied from $<0.01 \mathrm{mg} / \mathrm{L}$ as $\mathrm{P}$ at many sites to $15.4 \mathrm{mg} / \mathrm{L}$ as $\mathrm{P}$ at Powder River near Locate. A general guideline concentration of $0.10 \mathrm{mg} / \mathrm{L}$ for total phosphorus to prevent eutrophication was exceeded by the median total phosphorus concentrations at several sites in the Missouri and Yellowstone River basins (Milk River at Nashua, Missouri River near Culbertson, Powder River near Locate, and Yellowstone River near Sidney). The more restrictive ecoregion 
guideline of $0.075 \mathrm{mg} / \mathrm{L}$ for total phosphorus was exceeded in about 25 to more than 75 percent of samples at all the sites within the applicable areas of eastern and central Montana. Although medians did not exceed the general eutrophication guideline concentration of $0.10 \mathrm{mg} / \mathrm{L}$ in the Columbia River basin, the median concentrations of total phosphorus were consistently higher at sites in the Clark Fork subbasin, similar to the spatial pattern observed for total nitrogen. About 75 percent of the samples collected at Clark Fork at Turah Bridge and about 25 percent of the samples collected at Clark Fork at St. Regis exceeded the seasonal reach-specific numeric standards of $0.020 \mathrm{mg} / \mathrm{L}$ and $0.039 \mathrm{mg} / \mathrm{L}$, respectively, for total phosphorus.

Suspended-sediment concentrations varied widely across the network and ranged from 1 to $25,400 \mathrm{mg} / \mathrm{L}$. In both the Missouri and Yellowstone River basins, sites in the upper parts of the basins that are closer to the mountain headwaters typically had lower concentrations than at sites in the lower parts of the basin that drain extensive areas of semi-arid prairie. Median suspended-sediment concentrations were near or exceeded $100 \mathrm{mg} / \mathrm{L}$ in the Missouri River basin at Musselshell River at Mosby, Milk River at Nashua, and Missouri River near Culbertson. Median concentrations exceeded $100 \mathrm{mg} / \mathrm{L}$ in the Yellowstone River basin at Rosebud Creek at Rosebud, Tongue River at Miles City, Powder River near Locate, and Yellowstone River near Sidney. The maximum suspended-sediment concentration of $25,400 \mathrm{mg} / \mathrm{L}$ was measured at Powder River near Locate. Overall, suspended-sediment concentrations at Powder River near Locate were the highest in the network, with more than 25 percent of the samples exceeding $2,000 \mathrm{mg} / \mathrm{L}$. The lowest concentrations commonly were measured at sites in the Columbia River basin.

Dissolved-solids concentrations varied widely across the network, ranging from 23 to $6,200 \mathrm{mg} / \mathrm{L}$. In the Missouri and Yellowstone River basins, the highest values commonly occurred at sites in the lower parts of the basins. In the Missouri River basin, the Musselshell River at Mosby had notably higher concentrations relative to the other sites in the basin, and also had the highest concentration $(6,200 \mathrm{mg} / \mathrm{L})$ measured in the statewide network. About 90 percent of the samples from Musselshell River at Mosby exceeded the general irrigation guideline of $1,000 \mathrm{mg} / \mathrm{L}$. Concentrations of three other sites in the Missouri River basin (Peoples Creek near Dodson, Milk River at Nashua, and Poplar River near Poplar) exceeded the irrigation guideline in about 25 to 50 percent of the samples. In the Yellowstone River basin, two sites (Rosebud Creek near Rosebud and Powder River near Locate) consistently had the highest dissolved-solids concentrations, exceeding the $1,000 \mathrm{mg} / \mathrm{L}$ irrigation guideline concentration in more than 75 percent of the samples. Sites in the Columbia River basin commonly had low dissolved-solids concentrations compared to the other two basins and concentrations did not vary substantially with flow or season. None of the sites in the Columbia River basin had dissolved-solids concentrations that exceeded the general irrigation guideline.
SAR values, which can be used to indicate the suitability of water for irrigation, ranged from $<0.1$ to 12 across the network. Several sites in the lower parts of the Missouri and Yellowstone River basins had SAR values that were elevated relative to other sites in the basin. The general irrigation guideline of 7 was exceeded in more than 25 percent of the samples at Musselshell River at Mosby and Peoples Creek near Dodson, and in more than 50 percent of the samples at Poplar River near Poplar. Numeric standards for SAR have been established for the Rosebud Creek, Tongue River, and Powder River watersheds. Sites in these three streams had SAR values that were elevated relative to other sites in the Yellowstone River basin. Rosebud Creek near Rosebud had the maximum SAR value (12) measured in the network. SAR values at Rosebud Creek near Rosebud commonly exceeded and at Powder River near Locate occasionally exceeded the irrigation-season SAR standards of 4.5 and 7.5 for each stream, respectively. None of the samples from Tongue River at Miles City exceeded the Tongue River irrigation-season SAR standard of 4.5. SAR values in the Columbia River basin were low at all sites, with no exceedances of the irrigation guideline.

Total-recoverable concentrations of selected trace elements were compared to the State of Montana human-health standards for drinking-water supplies. Human-health standards for cadmium, chromium, and nickel were exceeded only infrequently in samples from network sites; no exceedances were measured for copper and zinc. Samples from most sites in the network had arsenic concentrations less than the human-health standard of $18 \mu \mathrm{g} / \mathrm{L}$; however, arsenic concentrations commonly exceeded the standard at two sites which receive geothermal waters enriched in arsenic from Yellowstone National Park. Arsenic concentrations in almost all samples collected at Missouri River at Toston, and about one-half the samples collected at Yellowstone River near Livingston, exceeded the human-health standard. The maximum arsenic concentration in the network $(48 \mu \mathrm{g} / \mathrm{L})$ was measured at Missouri River at Toston. Lead concentrations in samples from one to several sites in each major river basin exceeded the human-health standard of $15 \mu \mathrm{g} / \mathrm{L}$. Four sites in the Missouri River basin (Prickly Pear Creek near Clancy, Teton River at Loma, Musselshell River at Mosby, and Milk River at Nashua) had concentrations that exceeded the human-health standard for lead in more than 10 percent of the samples. Similarly, concentrations at three sites in the Yellowstone River basin (Rosebud Creek near Rosebud, Tongue River at Miles City, and Powder River near Locate) exceeded the human-health standard for lead in about 10 to more than 25 percent of the samples; Rosebud Creek near Rosebud had the highest lead concentration $(255 \mu \mathrm{g} / \mathrm{L})$ in the network. In the Columbia River basin, concentrations at only one site (Clark Fork at Turah Bridge) infrequently exceeded the human-health standard for lead.

Total-recoverable concentrations of selected trace elements also were compared to general numeric standards for the protection of aquatic life. Aquatic-life standards for chronic and acute toxicity vary with water hardness for several trace elements. General hardness-dependent aquatic-life 
standards for chronic and acute toxicity were calculated using average hardness for groups of sites having similar water quality to provide a reference comparison of sample concentrations to approximate thresholds of potential toxicity. Overall, exceedances of general chronic aquatic-life standards were infrequent at most sites throughout the network, and exceedances of general acute aquatic-life standards were rare. However, elevated trace-element concentrations were relatively common at some sites.

Arsenic and chromium concentrations did not exceed general aquatic-life standards at any of the network sites. Cadmium concentrations only sporadically exceeded chronic standards at a few sites. However, more than 25 percent of the samples from Powder River near Locate exceeded the chronic standard for cadmium; the maximum concentration $(10 \mu \mathrm{g} / \mathrm{L})$ exceeded the acute standard. Copper concentrations in most samples were less than general aquatic-life standards, although about one-half of the sites in the statewide network had one or more samples that exceeded either acute or chronic standards for copper. Persistent exceedances of chronic and acute standards for copper were most common (between 25 and 50 percent of the samples) at Clark Fork at Turah Bridge and, to a lesser degree (about 25 percent or more of the samples), at Yellowstone River near Livingston and Powder River near Locate. Lead concentrations at all sites were less than the acute standards; however, about one-half of the sites had one or more samples exceeding chronic standards. Six sites in the Missouri River basin infrequently equaled or exceeded the chronic standards for lead, but one site (Prickly Pear Creek near Clancy) exceeded the chronic standard in about 50 percent of the samples. Six sites in the Yellowstone River basin had samples that exceeded the chronic standards for lead; concentrations at two of the sites (Yellowstone River near Livingston and Powder River near Locate) exceeded the chronic standard in more than 25 percent of the samples. Although eight sites in the Columbia River basin had one or more samples that equaled or exceeded the chronic standard for lead, only the Clark Fork at Turah Bridge persistently exceeded the chronic standard in more than 25 percent of the samples. With the exception of two sites in the Yellowstone River basin (Rosebud Creek near Rosebud and Powder River near Locate), all sites in the network had nickel concentrations less than aquatic-life standards. Only four sites (Prickly Pear Creek near Clancy, Rosebud Creek near Rosebud, Powder River near Locate, and Clark Fork at Turah Bridge) occasionally exceeded aquatic-life standards for zinc.

Annual loads were estimated for selected constituents to illustrate relative differences among sites in order to identify upstream source areas contributing the largest proportion of the load at the most downstream site on the mainstem. Due to the low sampling frequency, the amount of data available at most sites is considered only marginally adequate to provide gross estimates of annual load.

Mean annual loads of nutrients were estimated for total ammonia plus organic nitrogen, total nitrogen, and total phosphorus. Mean annual loads of total ammonia plus organic nitrogen across the statewide network ranged from 2.73 tons at Peoples Creek near Dodson to 5,030 tons at Yellowstone River near Sidney. The largest mean annual loads of total ammonia plus organic nitrogen from upstream sources were transported past Missouri River at Toston (1,400 tons) in the Missouri River basin, Bighorn River near Bighorn (1,260 tons) in the Yellowstone River basin, and Clark Fork at St. Regis (1,290 tons) in the Columbia River basin. Mean annual loads for total nitrogen closely paralleled those of total ammonia plus organic nitrogen in both magnitude and spatial patterns. Mean annual loads for total phosphorus across the network ranged from 0.22 ton at Peoples Creek near Dodson to 1,930 tons at Yellowstone River near Sidney. The largest mean annual loads of total phosphorus from upstream sources were transported past Missouri River at Toston (239 tons) in the Missouri River basin, Yellowstone River near Livingston (572 tons) in the Yellowstone River basin, and Clark Fork at St. Regis (183 tons) in the Columbia River basin.

Mean annual loads of suspended sediment across the network ranged from 262 tons at Peoples Creek near Dodson to 2,890,000 tons at Yellowstone River near Sidney. The largest mean annual loads of suspended sediment from upstream sources were transported past Milk River at Nashua (319,000 tons) in the Missouri River basin, Powder River near Locate $(1,400,000$ tons) in the Yellowstone River basin, and Clark Fork at St. Regis (146,000 tons) in the Columbia River basin. One notable observation was that the combined mean annual load for the upper mainstem site Missouri River at Toston plus downstream tributaries accounted for only 26 percent of the mean annual suspended-sediment load at Missouri River near Culbertson. The large load passing the lower mainstem site, despite the likely deposition of much of the upstream sediment load in mainstem reservoirs, might indicate that other unmeasured sources, such as unsampled tributaries or channel erosion, are contributing large quantities of sediment to the Missouri River mainstem downstream from Fort Peck Reservoir.

Mean annual loads of dissolved solids ranged from 2,830 tons at Peoples Creek near Dodson to 2,970,000 tons at Yellowstone River near Sidney. The largest mean annual loads of dissolved solids from upstream sources were transported past Missouri River at Toston (682,000 tons) in the Missouri River basin, Bighorn River near Bighorn (1,410,000 tons) in the Yellowstone River basin, and Kootenai River below Libby Dam (1,230,000 tons) in the Columbia River basin.

Mean annual loads of total-recoverable arsenic ranged from 0.01 ton at Peoples Creek near Dodson to 109 tons at Missouri River at Toston. The largest source of arsenic in the Missouri River basin was an unsampled tributary basin (Madison River) upstream from Missouri River at Toston that previous studies have shown to transport large quantities of arsenic derived from geothermal sources in Yellowstone National Park. The Madison River basin supplied, by indirect estimation, about 92 percent of the arsenic load (109 tons) at Missouri River at Toston. The smaller arsenic load at Missouri River near Culbertson (40.2 tons) indicates that about 
65 percent of the combined arsenic load for Missouri River at Toston plus downstream tributaries presumably was deposited in mainstem reservoirs before reaching Culbertson. The largest mean annual arsenic load from upstream sources in the Yellowstone River basin was transported past Yellowstone River near Livingston (62.1 tons), which accounted for about 92 percent of the arsenic load at Yellowstone River near Sidney. Arsenic transport is generally conservative in the Yellowstone River basin owing to the absence of mainstem reservoirs, as indicated by the similarity of loads estimated for the Yellowstone River near Sidney and the combined loads from the upstream sampling sites. Arsenic loads were not estimated for most sites in the Columbia River basin due to a large number of concentrations less than the LRL. In the Clark Fork subbasin, the mean annual arsenic load (4.33 tons) transported past Clark Fork at Turah Bridge accounted for about 45 percent of the mean annual load (9.53 tons) at the Clark Fork at St. Regis.

Mean annual loads of total-recoverable copper ranged from 0.02 ton at Peoples Creek near Dodson to 80.9 tons at Yellowstone River near Sidney. The largest mean annual loads of copper from upstream sources were transported past Missouri River at Toston (13.6 tons) in the Missouri River basin, Yellowstone River near Livingston (18.8 tons) in the Yellowstone River basin, and Clark Fork at St. Regis and Flathead River at Perma (34.2 and 34.8 tons, respectively) in the Columbia River basin. In the Clark Fork subbasin, the largest mean annual copper load (17.7 tons) was transported past Clark Fork at Turah Bridge and accounted for about 52 percent of the mean annual load (34.2 tons) at Clark Fork at St. Regis.

\section{References Cited}

Allen, H.E., and Kramer, J.R., eds., 1972, Nutrients in natural waters: New York, Wiley, Environmental Science and Technology Series, $457 \mathrm{p}$.

Cannon, M.R., and Johnson, D.R., 2004, Estimated water use in Montana in 2000: U.S. Geological Survey Scientific Investigations Report 2004-5223, 50 p.

Childress, C.J.O., Foreman, W.T., Connor, B.F., and Maloney, T.J., 1999, New reporting procedures based on longterm method detection levels and some considerations for interpretations of water-quality data provided by the U.S. Geological Survey National Water Quality Laboratory: U.S. Geological Survey Open-File Report 99-193, 19 p.

Edwards, T.K., and Glysson, G.D., 1999, Field methods for measurement of fluvial sediment: U.S. Geological Survey Techniques of Water-Resources Investigations, book 3, chap. C2, 89 p.
Fishman, M.J., ed., 1993, Methods of analysis by the U.S. Geological Survey National Water Quality LaboratoryDetermination of inorganic and organic constituents in water and fluvial sediments: U.S. Geological Survey OpenFile Report 93-125, 217 p.

Fishman, M.J., and Friedman, L.C., eds., 1989, Methods for determination of inorganic substances in water and fluvial sediments: U.S. Geological Survey Techniques of WaterResources Investigations, book 5, chap. A1, 545 p.

Friedman, L.C., and Erdmann, D.E., 1982, Quality assurance practices for the chemical and biological analyses of water and fluvial sediment: U.S. Geological Survey Techniques of Water-Resources Investigations, book 5, chap. A6, 181 p.

Garbarino, J.R., and Struzeski, T.M., 1998, Methods of analysis by the U.S. Geological Survey National Water Quality Laboratory-Determination of elements in whole-water digests using inductively coupled plasma-optical emission spectrometry and inductively coupled plasma-mass spectrometry: U.S. Geological Survey Open-File Report 98-165, $101 \mathrm{p}$.

Guy, H.P., 1969, Laboratory theory and methods for sediment analysis: U.S. Geological Survey Techniques of WaterResources Investigations, book 5, chap. C1, 58 p.

Guy, H.P., 1970, Fluvial sediment concepts: U.S. Geological Survey Techniques of Water-Resources Investigations, book 3, chap. C1, 55 p.

Helsel, D.R., and Cohn, T.A., 1988, Estimation of descriptive statistics for multiply censored water quality data: Water Resources Research, v. 24, no. 12, p. 1997-2004.

Hem, J.D., 1985, Study and interpretation of the chemical characteristics of natural water ( $3 \mathrm{~d}$ ed.): U.S. Geological Survey Water-Supply Paper 2254, 63 p.

Hoffman, G.L., Fishman, M.J., and Garbarino, J.R., 1996, Methods of analysis by the U.S. Geological Survey National Water Quality Laboratory-In-bottle acid digestion of whole-water samples: U.S. Geological Survey Open-File Report 96-225, 28 p.

Hornberger, M.I., Lambing, J.H., Luoma, S.N., and Axtmann, E.V., 1997, Spatial and temporal trends of trace metals in surface water, bed sediment, and biota of the upper Clark Fork basin, Montana, 1985-95: U.S. Geological Survey Open-File Report 97-669, 84 p.

Horowitz, A.J., 1991, A primer on sediment-trace element chemistry, $2^{\text {nd }}$ ed.: Chelsea, Mich., Lewis Publishers, Inc., $136 \mathrm{p}$. 
Horowitz, A.J., Demas, C.R., Fitzgerald, K.K., Miller, T.L., and Rickert, D.A., 1994, U.S. Geological Survey protocol for the collection and processing of surface-water samples for the subsequent determination of inorganic constituents in filtered water: U.S. Geological Survey Open-File Report 94-539, 57 p.

Jones, B.E., 1987, Quality control manual of the U.S. Geological Survey's National Water Quality Laboratory: U.S. Geological Survey Open-File Report 87-457, 17 p.

Jones, S.R., and Garbarino, J.R., 1999, Methods of analysis by the U.S. Geological Survey National Water Quality Laboratory-Determination of arsenic and selenium in water and sediment by graphite furnace-atomic absorption spectrometry: U.S. Geological Survey Open-File Report 98-639, 39 p.

Kimball, B.A., Nimick, D.A., Gerner, L.J., and Runkel, R.L., 1999, Quantification of metal loading in Fisher Creek by tracer injection and synoptic sampling, Park County, Montana, August, 1997: U.S. Geological Survey WaterResources Investigations Report 99-4119, 40 p.

Klein, T.L., Thamke, J.N., Harper, D.D., Farag, A.M., Nimick, D.A., and Fey, D.L., 2003, Water-quality, bed-sediment, and biological data for streams in the upper Prickly Pear Creek watershed, Montana, 2001: U.S. Geological Survey OpenFile Report 03-032, version 1.1, 103 p.

Knapton, J.R., and Nimick, D.A., 1991, Quality assurance for water-quality activities of the U.S. Geological Survey in Montana: U.S. Geological Survey Open-File Report 91-216, $41 \mathrm{p}$.

Lambing, J.H., 1991, Water-quality and transport characteristics of suspended sediment and trace elements in streamflow of the upper Clark Fork basin from Galen to Missoula, Montana, 1985-90: U.S. Geological Survey WaterResources Investigations Report 91-4139, 73 p.

Lambing, J.H., 1998, Estimated 1996-97 and long-term average annual loads for suspended sediment and selected trace metals in streamflow of the upper Clark Fork basin from Warm Springs to Missoula, Montana: U.S. Geological Survey Water-Resources Investigations Report 98-4137, 35 p.

Lambing, J.H., and Dodge, K.A., 1993, Quality assurance for laboratory analysis of suspended-sediment samples by the U.S. Geological Survey in Montana: U.S. Geological Survey Open-File Report 93-131, 34 p.

Mackenthun, K.M., 1969, The practice of water pollution biology: U.S. Department of the Interior, Federal Water Pollution Control Administration, Division of Technical Support, $281 \mathrm{p}$.
McLain, Betty, 1993, Methods of analysis by the U.S. Geological Survey National Water Quality Laboratory-Determination of chromium in water by graphite furnace-atomic absorption spectrophotometry: U.S. Geological Survey Open-File Report 93-449, 16 p.

Montana Department of Environmental Quality, 2002a, Water-use classifications: Administrative Rules of Montana 17.30.607 to 17.30 .611 , p. 17-2697 to $17-2707$.

Montana Department of Environmental Quality, 2002b, Classification standards: Administrative Rules of Montana 17.30.621 to 17.30 .629 , p. $17-2711$ to $17-2736$.

Montana Department of Environmental Quality, 2003, Numeric standards for electrical conductivity (EC) and sodium adsorption ratio (SAR): Administrative Rules of Montana 17.30 .670 , p. $17-2757$ to $17-2758$.

Montana Department of Environmental Quality, 2004, Montana numeric water quality standards: Administrative Rules of Montana 17.30.619, Circular WQB-7, 38 p.

Moody, D.W., Chase, E.B., and Aronson, D.A., 1986, National Water Summary 1985-Hydrologic events and surfacewater resources: U.S. Geological Survey Water-Supply Paper 2300, 506 p.

Nimick, D.A., Church, S.E., and Finger, S.E., eds., 2004, Integrated investigation of environmental effects of historical mining in the Basin and Boulder mining districts, Boulder River watershed, Jefferson County, Montana: U.S. Geological Survey Professional Paper 1652, 523 p.

Nimick, D.A., Moore, J.N., Dalby, C.E., and Savka, M.W., 1998, The fate of geothermal arsenic in the Madison and Missouri Rivers, Montana and Wyoming: Water Resources Research, v. 34, no. 11, p. 3051-3067.

Playle, R.C., 2004, Using multiple metal-gill binding models and the toxic unit concept to help reconcile multiple-metal toxicity results: Aquatic Toxicology, v. 67, p. 359-370.

Pritt, J.W., and Raese, J.W., eds., 1995, Quality assurance/ quality control manual-National Water Quality Laboratory: U.S. Geological Survey Open-File Report 95-443, $35 \mathrm{p}$.

Rantz, S.E., and others, 1982, Measurement and computation of streamflow: U.S. Geological Survey Water-Supply Paper 2175, 2 v., 631 p.

Ross, C.P., Andrews, D.A., and Witkind, I.J., 1955, Geologic map of Montana: U.S. Geological Survey, scale 1:500,000.

Stumm, Werner, and Morgan, J.J., eds., 1996, Aquatic chemistry-Chemical equilibria and rates in natural waters (3d ed.): New York, Wiley, 1,022 p. 
Taylor, J.K., 1987, Quality assurance of chemical measurements: Chelsea, Mich., Lewis Publishers, 328 p.

U.S. Department of Agriculture, 2002, Natural Resources Conservation Service, Assessing water quality for agriculture and aquatic life uses: Environment Technical Note No. MT-1, 27 p.

U.S. Environmental Protection Agency, 1986, Quality criteria for water 1986: Washington, D.C., Office of Water Regulations and Standards, EPA 440/5-86-001, unpaged.

U.S. Environmental Protection Agency, 2001a, Ambient water quality criteria recommendations-Rivers and streams in nutrient ecoregion 4: EPA 822-B-01-013, $30 \mathrm{p}$.

U.S. Environmental Protection Agency, 2001b, Ambient water quality criteria recommendations-Rivers and streams in nutrient ecoregion 5: EPA 822-B-01-014, 29 p.

U.S. Geological Survey, issued annually, Water resources data, Montana: U.S. Geological Survey Water-Data Report.

U.S. Geological Survey, variously dated, National field manual for the collection of water-quality data: U.S. Geological Survey Techniques of Water-Resources Investigations, book 9, chap. A1-A9, available online at http://pubs.water.usgs. gov/twri9A/

Wagner, R.J., Mattraw, H.C., Ritz, G.F., and Smith, B.A., 2000, Guidelines and standard procedures for continuous water-quality monitors-Site selection, field operation, calibration, record computation, and reporting: U.S. Geological Survey Water-Resources Investigations Report 00-4252, $53 \mathrm{p}$.

Ward, J.R., and Harr, C.A., eds., 1990, Methods for collection and processing of surface-water and bed-material samples for physical and chemical analyses: U.S. Geological Survey Open-File Report 90-140, 71 p. 
Data 
Table 13. Analytical results for replicate samples from sites in the statewide monitoring network in Montana, water years 1999-2003. [Abbreviations: $\mathrm{CaCO}_{3}$, calcium carbonate; E, estimated; $\mu \mathrm{g} / \mathrm{L}$, micrograms per liter; mg/L, milligrams per liter; mm, millimeters; $\mathrm{N}$, nitrogen; P, phosphorus. Symbols: --, no data; <, less than laboratory reporting level]

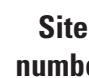

number Station

(fig. 1)
Station
number

number Station name
Date Time
Calcium, dissolved (mg/L)

$\begin{array}{cc}\begin{array}{c}\text { Magnesium, } \\ \text { dissolved } \\ (\mathrm{mg} / \mathrm{L})\end{array} & \begin{array}{c}\text { Potassium, } \\ \text { dissolved } \\ (\mathrm{mg} / \mathrm{L})\end{array}\end{array}$

Sodium dissolved (mg/L)

\begin{tabular}{|c|c|c|c|c|c|c|c|c|}
\hline 1 & 06018500 & $\begin{array}{l}\text { Beaverhead River near Twin } \\
\text { Bridges }\end{array}$ & $\begin{array}{l}05 / 22 / 2002 \\
05 / 22 / 2002\end{array}$ & $\begin{array}{l}1430 \\
1440\end{array}$ & $\begin{array}{l}88.2 \\
85.8\end{array}$ & $\begin{array}{l}37.1 \\
36.0\end{array}$ & $\begin{array}{l}7.90 \\
7.44\end{array}$ & $\begin{array}{l}34.8 \\
33.9\end{array}$ \\
\hline 1 & 06018500 & $\begin{array}{l}\text { Beaverhead River near Twin } \\
\text { Bridges }\end{array}$ & $\begin{array}{l}05 / 20 / 2003 \\
05 / 20 / 2003\end{array}$ & $\begin{array}{l}0930 \\
0940\end{array}$ & $\begin{array}{l}-- \\
--\end{array}$ & -- & -- & -- \\
\hline 2 & 06036650 & $\begin{array}{l}\text { Jefferson River near Three } \\
\text { Forks }\end{array}$ & $\begin{array}{l}02 / 15 / 2001 \\
02 / 15 / 2001\end{array}$ & $\begin{array}{l}1410 \\
1415\end{array}$ & $\begin{array}{l}-- \\
--\end{array}$ & -- & $\begin{array}{l}-- \\
--\end{array}$ & $\begin{array}{l}-- \\
--\end{array}$ \\
\hline 4 & 06054500 & Missouri River at Toston & $\begin{array}{l}06 / 01 / 1999 \\
06 / 01 / 1999\end{array}$ & $\begin{array}{l}1440 \\
1445\end{array}$ & $\begin{array}{l}23.1 \\
23.0\end{array}$ & $\begin{array}{l}6.26 \\
6.24\end{array}$ & $\begin{array}{l}2.59 \\
2.62\end{array}$ & $\begin{array}{l}10.2 \\
10.2\end{array}$ \\
\hline 4 & 06054500 & Missouri River at Toston & $\begin{array}{l}08 / 21 / 2001 \\
08 / 21 / 2001\end{array}$ & $\begin{array}{l}1345 \\
1350\end{array}$ & $\begin{array}{l}28.3 \\
27.9\end{array}$ & $\begin{array}{l}9.49 \\
9.33\end{array}$ & $\begin{array}{l}4.05 \\
4.08\end{array}$ & $\begin{array}{l}26.0 \\
26.0\end{array}$ \\
\hline 5 & 06061500 & $\begin{array}{l}\text { Prickly Pear Creek near } \\
\text { Clancy }\end{array}$ & $\begin{array}{l}05 / 20 / 2002 \\
05 / 20 / 2002\end{array}$ & $\begin{array}{l}1110 \\
1120\end{array}$ & $\begin{array}{l}16.1 \\
15.9\end{array}$ & $\begin{array}{l}3.52 \\
3.49\end{array}$ & $\begin{array}{l}1.65 \\
1.73\end{array}$ & $\begin{array}{l}6.26 \\
6.28\end{array}$ \\
\hline 5 & 06061500 & $\begin{array}{l}\text { Prickly Pear Creek near } \\
\text { Clancy }\end{array}$ & $\begin{array}{l}05 / 20 / 2003 \\
05 / 20 / 2003\end{array}$ & $\begin{array}{l}0900 \\
0905\end{array}$ & $\begin{array}{l}23.1 \\
22.2\end{array}$ & $\begin{array}{l}5.03 \\
4.89\end{array}$ & $\begin{array}{l}1.98 \\
2.04\end{array}$ & $\begin{array}{l}8.78 \\
8.86\end{array}$ \\
\hline 8 & 06108800 & Teton River at Loma & $\begin{array}{l}05 / 23 / 2001 \\
05 / 23 / 2001\end{array}$ & $\begin{array}{l}0820 \\
0830\end{array}$ & $\begin{array}{l}73.0 \\
72.4\end{array}$ & $\begin{array}{l}79.6 \\
80.1\end{array}$ & $\begin{array}{l}4.15 \\
4.12\end{array}$ & $\begin{array}{l}118 \\
117\end{array}$ \\
\hline 8 & 06108800 & Teton River at Loma & $\begin{array}{l}05 / 29 / 2002 \\
05 / 29 / 2002\end{array}$ & $\begin{array}{l}1320 \\
1330\end{array}$ & $\begin{array}{l}56.4 \\
56.5\end{array}$ & $\begin{array}{l}51.8 \\
51.1\end{array}$ & $\begin{array}{l}2.73 \\
2.70\end{array}$ & $\begin{array}{l}60.5 \\
58.5\end{array}$ \\
\hline 8 & 06108800 & Teton River at Loma & $\begin{array}{l}06 / 17 / 2003 \\
06 / 17 / 2003\end{array}$ & $\begin{array}{l}1440 \\
1450\end{array}$ & $\begin{array}{l}60.5 \\
59.8\end{array}$ & $\begin{array}{l}65.6 \\
65.1\end{array}$ & $\begin{array}{l}3.64 \\
3.57\end{array}$ & $\begin{array}{l}91.1 \\
90.2\end{array}$ \\
\hline 12 & 06174500 & Milk River at Nashua & $\begin{array}{l}06 / 14 / 2001 \\
06 / 14 / 2001\end{array}$ & $\begin{array}{l}1115 \\
1125\end{array}$ & $\begin{array}{l}45.5 \\
45.4\end{array}$ & $\begin{array}{l}21.0 \\
20.9\end{array}$ & $\begin{array}{l}6.62 \\
6.49\end{array}$ & $\begin{array}{l}122 \\
123\end{array}$ \\
\hline 12 & 06174500 & Milk River at Nashua & $\begin{array}{l}05 / 05 / 2002 \\
05 / 05 / 2002\end{array}$ & $\begin{array}{l}1215 \\
1220\end{array}$ & $\begin{array}{l}86.9 \\
85.9\end{array}$ & $\begin{array}{l}43.5 \\
44.1\end{array}$ & $\begin{array}{l}7.64 \\
6.51\end{array}$ & $\begin{array}{l}263 \\
262\end{array}$ \\
\hline 12 & 06174500 & Milk River at Nashua & $\begin{array}{l}05 / 05 / 2003 \\
05 / 05 / 2003\end{array}$ & $\begin{array}{l}1345 \\
1350\end{array}$ & $\begin{array}{l}53.5 \\
53.5\end{array}$ & $\begin{array}{l}25.6 \\
25.6\end{array}$ & $\begin{array}{l}8.98 \\
9.04\end{array}$ & $\begin{array}{l}102 \\
101\end{array}$ \\
\hline 13 & 06181000 & Poplar River near Poplar & $\begin{array}{l}05 / 11 / 2000 \\
05 / 11 / 2000\end{array}$ & $\begin{array}{l}1045 \\
1055\end{array}$ & $\begin{array}{l}26.6 \\
26.4\end{array}$ & $\begin{array}{l}33.8 \\
34.0\end{array}$ & $\begin{array}{l}6.03 \\
5.97\end{array}$ & $\begin{array}{l}272 \\
274\end{array}$ \\
\hline
\end{tabular}


Table 13. Analytical results for replicate samples from sites in the statewide monitoring network in Montana, water years 1999-2003. -Continued

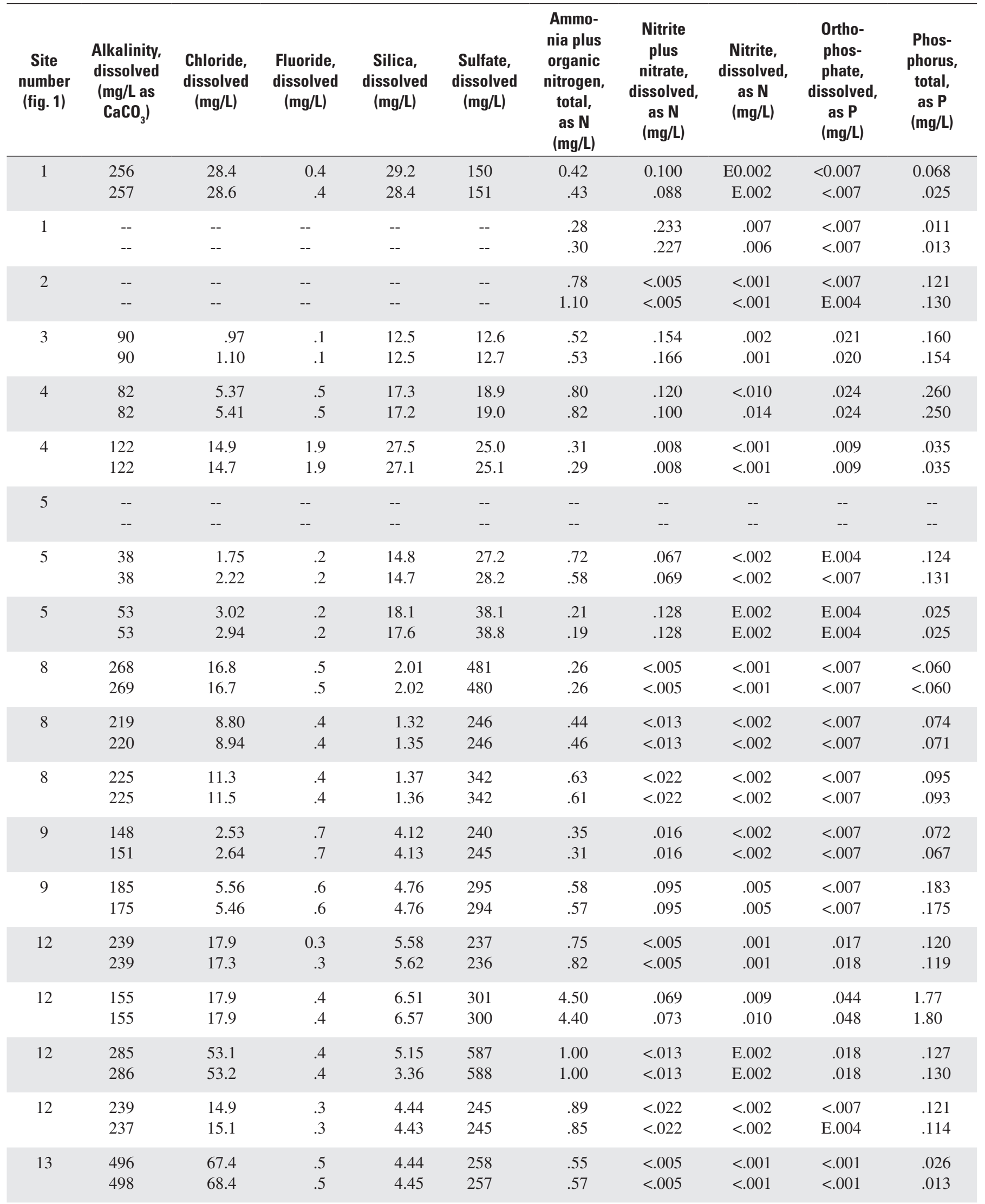


Table 13. Analytical results for replicate samples from sites in the statewide monitoring network in Montana, water years 1999-2003. -Continued

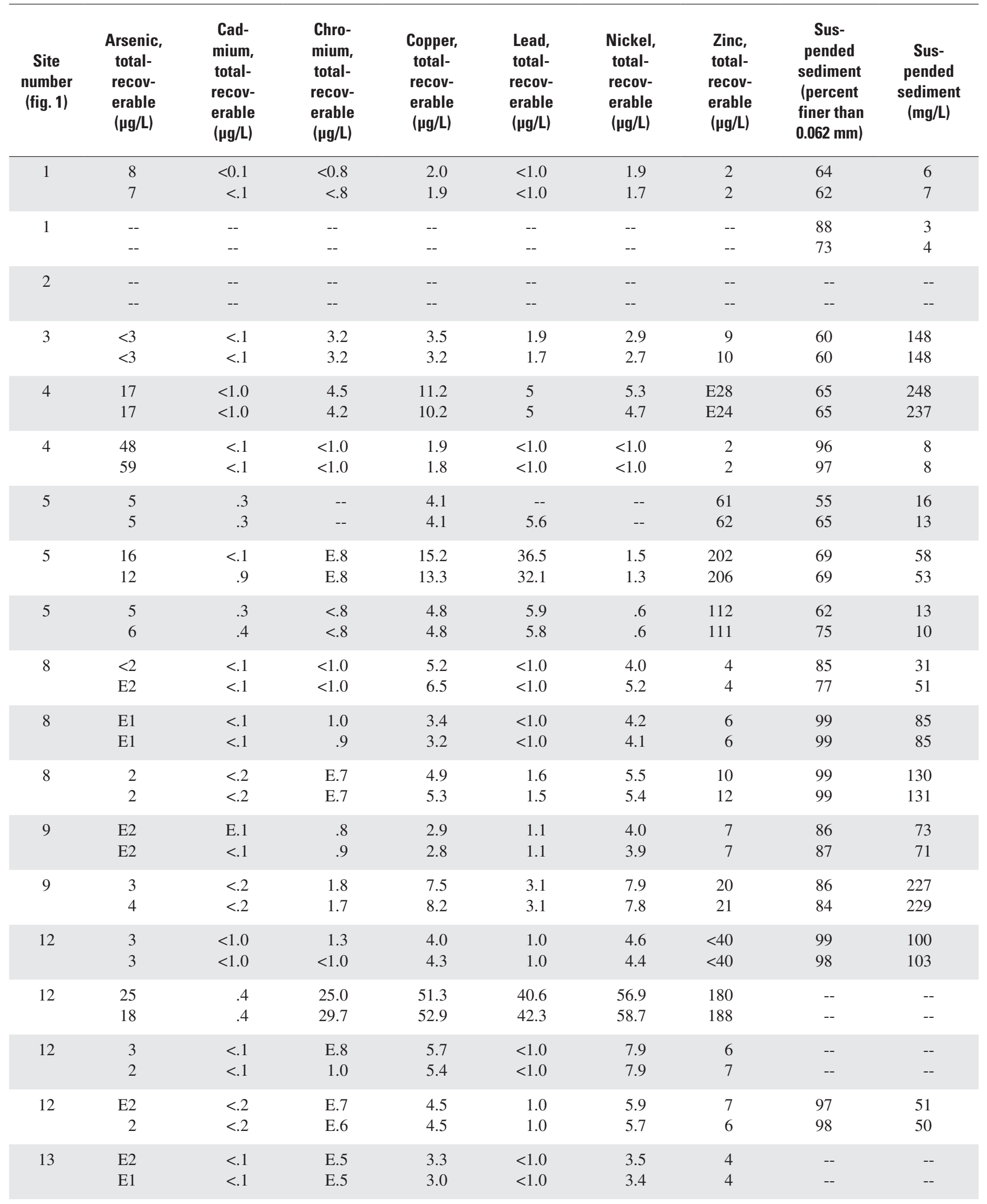


Table 13. Analytical results for replicate samples from sites in the statewide monitoring network in Montana, water years 1999-2003. -Continued

Site (fig. 1)

\section{Station} number
Station name
Date Time
Calcium, Magnesium, Potassium, dissolved (mg/L)

$\begin{array}{cc}\begin{array}{c}\text { dissolved } \\ (\mathrm{mg} / \mathrm{L})\end{array} & \begin{array}{c}\text { dissolved } \\ (\mathrm{mg} / \mathrm{L})\end{array}\end{array}$

Sodium, dissolved (mg/L)

\begin{tabular}{|c|c|c|c|c|c|c|c|c|}
\hline 14 & 06185500 & $\begin{array}{l}\text { Missouri River near } \\
\text { Culbertson }\end{array}$ & $\begin{array}{l}05 / 18 / 1999 \\
05 / 18 / 1999\end{array}$ & $\begin{array}{l}1100 \\
1110\end{array}$ & $\begin{array}{l}41.6 \\
41.3\end{array}$ & $\begin{array}{l}18.9 \\
18.7\end{array}$ & $\begin{array}{l}3.97 \\
3.98\end{array}$ & $\begin{array}{l}67.9 \\
67.7\end{array}$ \\
\hline 14 & 06185500 & $\begin{array}{l}\text { Missouri River near } \\
\text { Culbertson }\end{array}$ & $\begin{array}{l}05 / 01 / 2000 \\
05 / 01 / 2000\end{array}$ & $\begin{array}{l}1215 \\
1225\end{array}$ & $\begin{array}{l}49.8 \\
50.1\end{array}$ & $\begin{array}{l}19.4 \\
19.4\end{array}$ & $\begin{array}{l}3.52 \\
3.41\end{array}$ & $\begin{array}{l}39.6 \\
40.5\end{array}$ \\
\hline 14 & 06185500 & $\begin{array}{l}\text { Missouri River near } \\
\text { Culbertson }\end{array}$ & $\begin{array}{l}06 / 04 / 2001 \\
06 / 04 / 2001\end{array}$ & $\begin{array}{l}1230 \\
1240\end{array}$ & $\begin{array}{l}49.4 \\
50.2\end{array}$ & $\begin{array}{l}18.9 \\
19.2\end{array}$ & $\begin{array}{l}3.50 \\
3.58\end{array}$ & $\begin{array}{l}40.1 \\
40.6\end{array}$ \\
\hline 14 & 06185500 & $\begin{array}{l}\text { Missouri River near } \\
\text { Culbertson }\end{array}$ & $\begin{array}{l}09 / 04 / 2001 \\
09 / 04 / 2001\end{array}$ & $\begin{array}{l}1030 \\
1040\end{array}$ & $\begin{array}{l}49.6 \\
49.9\end{array}$ & $\begin{array}{l}19.5 \\
19.8\end{array}$ & $\begin{array}{l}3.67 \\
3.72\end{array}$ & $\begin{array}{l}42.6 \\
42.0\end{array}$ \\
\hline 14 & 06185500 & $\begin{array}{l}\text { Missouri River near } \\
\text { Culbertson }\end{array}$ & $\begin{array}{l}05 / 28 / 2002 \\
05 / 28 / 2002\end{array}$ & $\begin{array}{l}1030 \\
1040\end{array}$ & $\begin{array}{l}48.3 \\
50.2\end{array}$ & $\begin{array}{l}20.0 \\
19.3\end{array}$ & $\begin{array}{l}3.60 \\
3.59\end{array}$ & $\begin{array}{l}39.5 \\
41.6\end{array}$ \\
\hline 14 & 06185500 & $\begin{array}{l}\text { Missouri River near } \\
\text { Culbertson }\end{array}$ & $\begin{array}{l}05 / 19 / 2003 \\
05 / 19 / 2003\end{array}$ & $\begin{array}{l}1115 \\
1125\end{array}$ & $\begin{array}{l}48.9 \\
48.9\end{array}$ & $\begin{array}{l}20.6 \\
20.6\end{array}$ & $\begin{array}{l}4.61 \\
4.48\end{array}$ & $\begin{array}{l}57.9 \\
57.6\end{array}$ \\
\hline 15 & 06192500 & $\begin{array}{l}\text { Yellowstone River near } \\
\text { Livingston }\end{array}$ & $\begin{array}{l}08 / 18 / 1999 \\
08 / 18 / 1999\end{array}$ & $\begin{array}{l}0800 \\
0810\end{array}$ & $\begin{array}{l}12.9 \\
12.5\end{array}$ & $\begin{array}{l}4.49 \\
4.35\end{array}$ & $\begin{array}{l}2.70 \\
2.89\end{array}$ & $\begin{array}{l}11.9 \\
11.4\end{array}$ \\
\hline 16 & 06195600 & $\begin{array}{l}\text { Shields River near Livings- } \\
\text { ton }\end{array}$ & $\begin{array}{l}08 / 09 / 2000 \\
08 / 09 / 2000\end{array}$ & $\begin{array}{l}1015 \\
1020\end{array}$ & $\begin{array}{l}-- \\
--\end{array}$ & $\begin{array}{l}-- \\
--\end{array}$ & $\begin{array}{l}-- \\
--\end{array}$ & $\begin{array}{l}-- \\
--\end{array}$ \\
\hline 17 & 06200000 & Boulder River at Big Timber & $\begin{array}{l}08 / 23 / 2001 \\
08 / 23 / 2001\end{array}$ & $\begin{array}{l}1100 \\
1110\end{array}$ & -- & -- & $\begin{array}{l}-- \\
--\end{array}$ & -- \\
\hline 18 & 06205000 & $\begin{array}{l}\text { Stillwater River near } \\
\text { Absarokee }\end{array}$ & $\begin{array}{l}10 / 25 / 2001 \\
10 / 25 / 2001\end{array}$ & $\begin{array}{l}1340 \\
1350\end{array}$ & $\begin{array}{l}-- \\
--\end{array}$ & $\begin{array}{l}-- \\
--\end{array}$ & $\begin{array}{l}-- \\
--\end{array}$ & -- \\
\hline 18 & 06205000 & $\begin{array}{l}\text { Stillwater River near } \\
\text { Absarokee }\end{array}$ & $\begin{array}{l}09 / 08 / 2003 \\
09 / 08 / 2003\end{array}$ & $\begin{array}{l}0845 \\
0855\end{array}$ & $\begin{array}{l}-- \\
--\end{array}$ & $\begin{array}{l}-- \\
--\end{array}$ & $\begin{array}{l}-- \\
--\end{array}$ & -- \\
\hline 19 & 06208500 & $\begin{array}{l}\text { Clarks Fork Yellowstone } \\
\text { River at Edgar }\end{array}$ & $\begin{array}{l}05 / 21 / 2002 \\
05 / 21 / 2002\end{array}$ & $\begin{array}{l}1020 \\
1030\end{array}$ & $\begin{array}{l}14.3 \\
14.4\end{array}$ & $\begin{array}{l}3.34 \\
3.34\end{array}$ & $\begin{array}{l}.54 \\
.54\end{array}$ & $\begin{array}{l}5.05 \\
5.08\end{array}$ \\
\hline 19 & 06208500 & $\begin{array}{l}\text { Clarks Fork Yellowstone } \\
\text { River at Edgar }\end{array}$ & $\begin{array}{l}06 / 05 / 2003 \\
06 / 05 / 2003\end{array}$ & $\begin{array}{l}0845 \\
0855\end{array}$ & $\begin{array}{l}15.5 \\
15.4\end{array}$ & $\begin{array}{l}3.87 \\
3.84\end{array}$ & $\begin{array}{l}.72 \\
.71\end{array}$ & $\begin{array}{l}5.92 \\
5.89\end{array}$ \\
\hline 20 & 06294500 & Bighorn River near Bighorn & $\begin{array}{l}05 / 17 / 2001 \\
05 / 17 / 2001\end{array}$ & $\begin{array}{l}1000 \\
1010\end{array}$ & $\begin{array}{l}80.9 \\
82.1\end{array}$ & $\begin{array}{l}29.8 \\
30.1\end{array}$ & $\begin{array}{l}3.47 \\
3.49\end{array}$ & $\begin{array}{l}74.1 \\
75.7\end{array}$ \\
\hline 21 & 06296003 & $\begin{array}{l}\text { Rosebud Creek at mouth, } \\
\text { near Rosebud }\end{array}$ & $\begin{array}{l}06 / 16 / 2000 \\
06 / 16 / 2000\end{array}$ & $\begin{array}{l}1125 \\
1135\end{array}$ & $\begin{array}{l}71.2 \\
72.2\end{array}$ & $\begin{array}{l}124 \\
126\end{array}$ & $\begin{array}{l}25.1 \\
25.6\end{array}$ & $\begin{array}{l}340 \\
342\end{array}$ \\
\hline 22 & 06308500 & Tongue River at Miles City & $\begin{array}{l}06 / 15 / 1999 \\
06 / 15 / 1999\end{array}$ & $\begin{array}{l}0900 \\
0910\end{array}$ & $\begin{array}{l}27.6 \\
27.7\end{array}$ & $\begin{array}{l}13.8 \\
13.9\end{array}$ & $\begin{array}{l}2.21 \\
2.28\end{array}$ & $\begin{array}{l}14.0 \\
14.0\end{array}$ \\
\hline 23 & 06326500 & Powder River near Locate & $\begin{array}{l}12 / 12 / 2002 \\
12 / 12 / 2002\end{array}$ & $\begin{array}{l}0830 \\
0835\end{array}$ & $\begin{array}{l}186 \\
190\end{array}$ & $\begin{array}{l}84.7 \\
87.0\end{array}$ & $\begin{array}{l}9.33 \\
9.43\end{array}$ & $\begin{array}{l}352 \\
360\end{array}$ \\
\hline 24 & 06329500 & $\begin{array}{l}\text { Yellowstone River near } \\
\text { Sidney }\end{array}$ & $\begin{array}{l}06 / 10 / 1999 \\
06 / 10 / 1999\end{array}$ & $\begin{array}{l}0800 \\
0810\end{array}$ & $\begin{array}{l}32.0 \\
32.4\end{array}$ & $\begin{array}{l}11.6 \\
11.7\end{array}$ & $\begin{array}{l}2.35 \\
2.34\end{array}$ & $\begin{array}{l}32.3 \\
32.5\end{array}$ \\
\hline 24 & 06329500 & $\begin{array}{l}\text { Yellowstone River near } \\
\text { Sidney }\end{array}$ & $\begin{array}{l}06 / 05 / 2000 \\
06 / 05 / 2000\end{array}$ & $\begin{array}{l}1200 \\
1210\end{array}$ & $\begin{array}{l}25.2 \\
24.9\end{array}$ & $\begin{array}{l}8.76 \\
8.70\end{array}$ & $\begin{array}{l}1.78 \\
1.87\end{array}$ & $\begin{array}{l}20.5 \\
20.7\end{array}$ \\
\hline
\end{tabular}


Table 13. Analytical results for replicate samples from sites in the statewide monitoring network in Montana, water years 1999-2003. -Continued

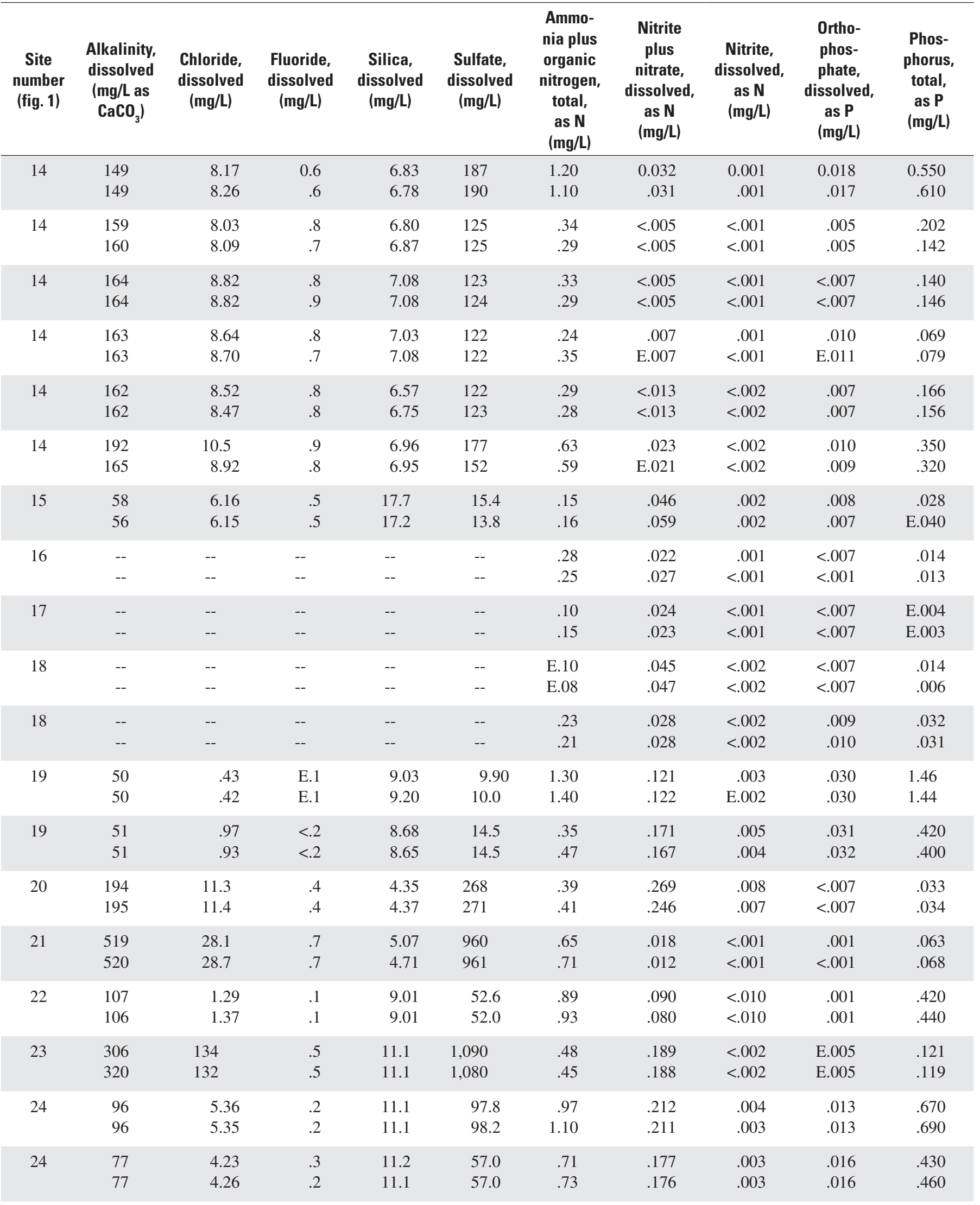


Table 13. Analytical results for replicate samples from sites in the statewide monitoring network in Montana, water years 1999-2003. -Continued

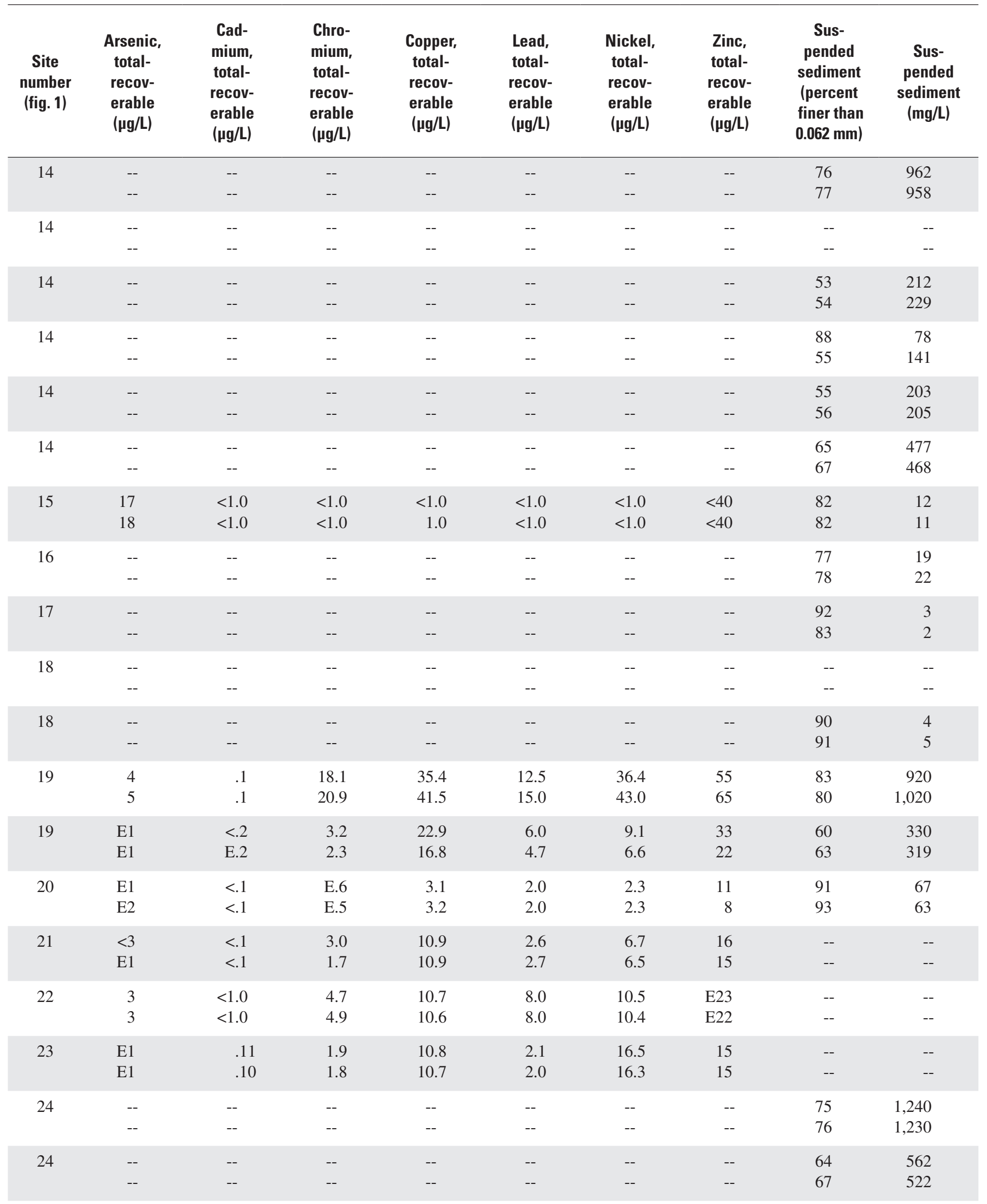


Table 13. Analytical results for replicate samples from sites in the statewide monitoring network in Montana, water years 1999-2003. -Continued

\begin{tabular}{|c|c|c|c|c|c|c|c|c|}
\hline $\begin{array}{c}\text { Site } \\
\text { number } \\
\text { (fig. 1) }\end{array}$ & $\begin{array}{l}\text { Station } \\
\text { number }\end{array}$ & Station name & Date & Time & $\begin{array}{l}\text { Calcium, } \\
\text { dissolved } \\
\text { (mg/L) }\end{array}$ & $\begin{array}{l}\text { Magnesium, } \\
\text { dissolved } \\
\text { (mg/L) }\end{array}$ & $\begin{array}{c}\text { Potassium, } \\
\text { dissolved } \\
\text { (mg/L) }\end{array}$ & $\begin{array}{c}\text { Sodium, } \\
\text { dissolved } \\
\text { (mg/L) }\end{array}$ \\
\hline
\end{tabular}

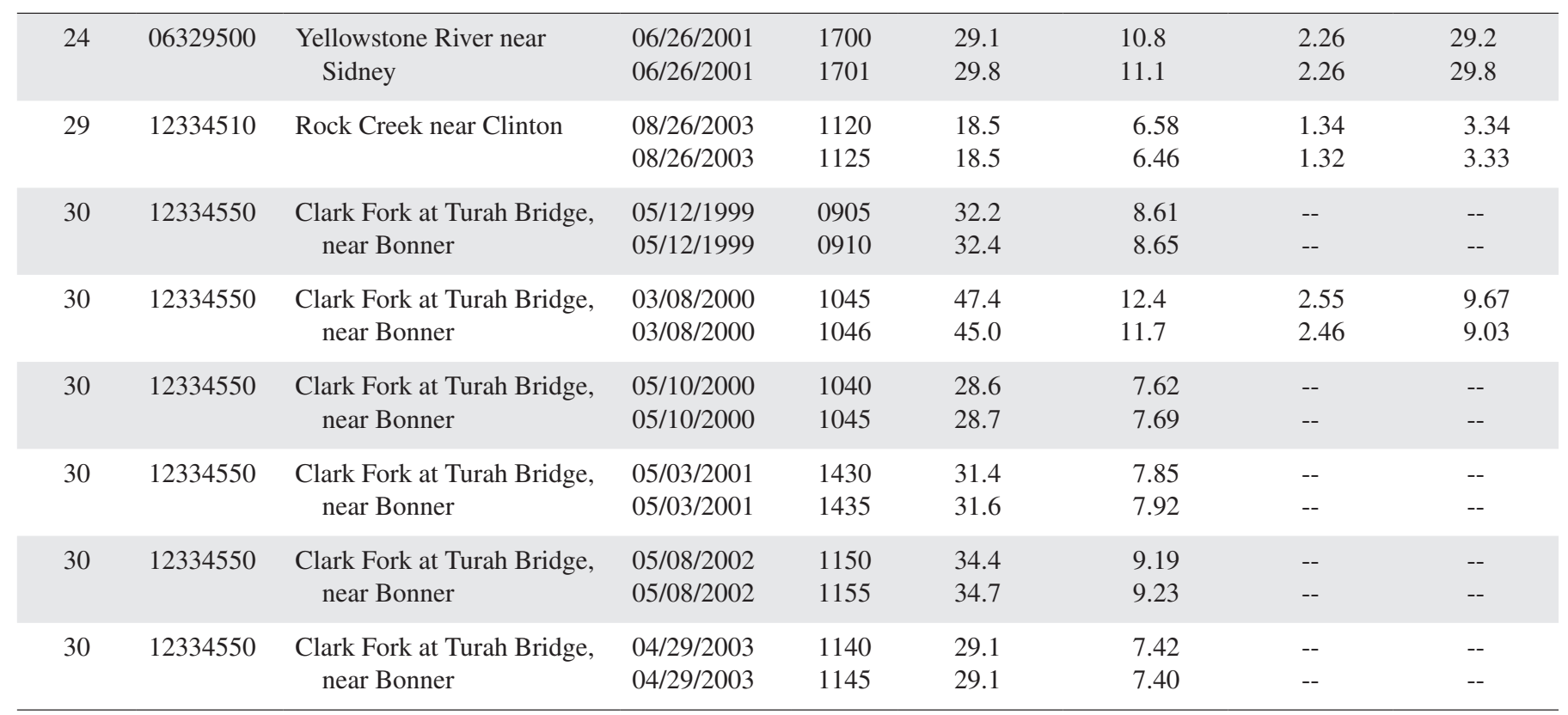


Table 13. Analytical results for replicate samples from sites in the statewide monitoring network in Montana, water years 1999-2003. -Continued

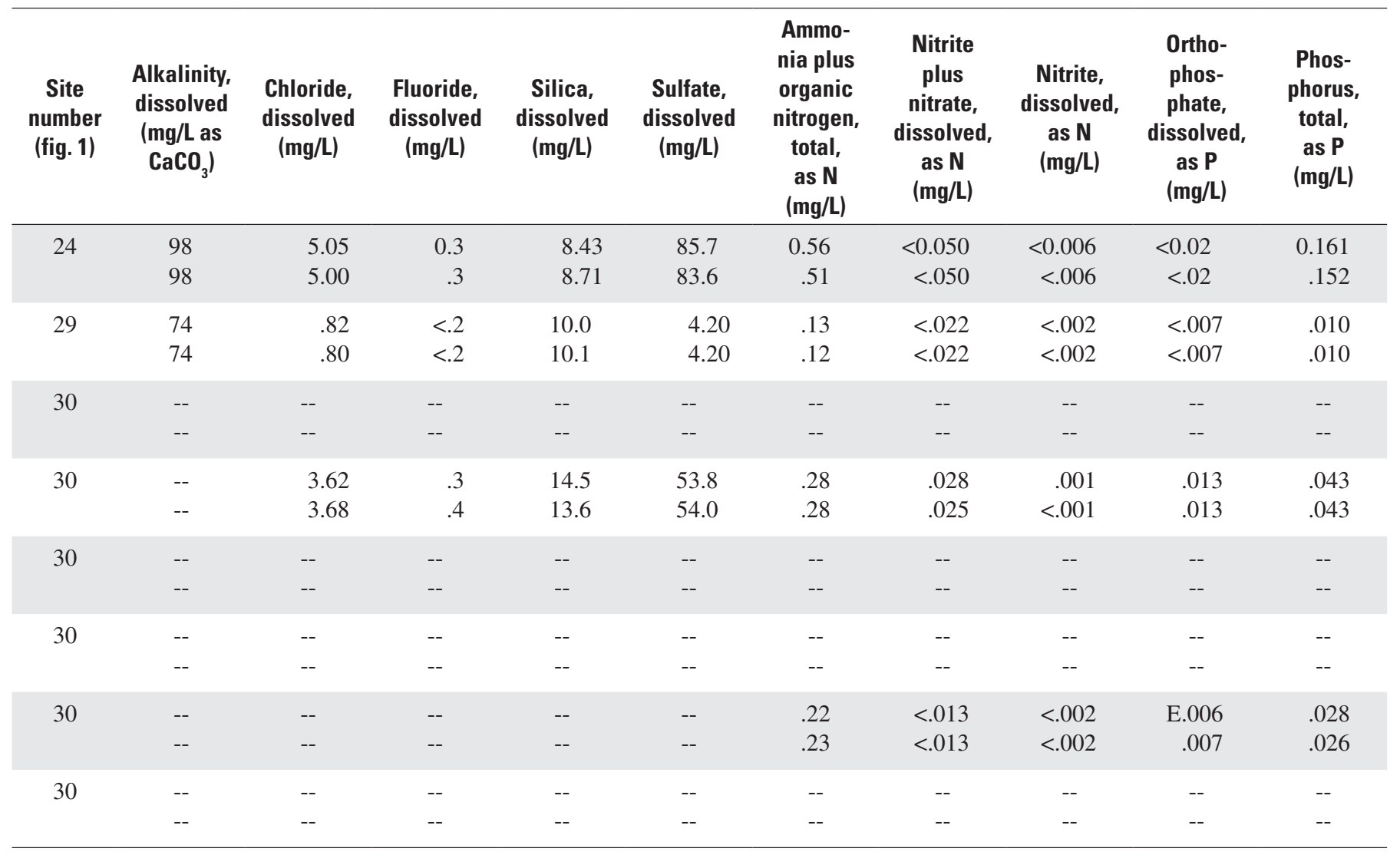


98 Water-Quality Characteristics of Montana Streams in a Statewide Monitoring Network, 1999-2003

Table 13. Analytical results for replicate samples from sites in the statewide monitoring network in Montana, water years $1999-2003$. -Continued

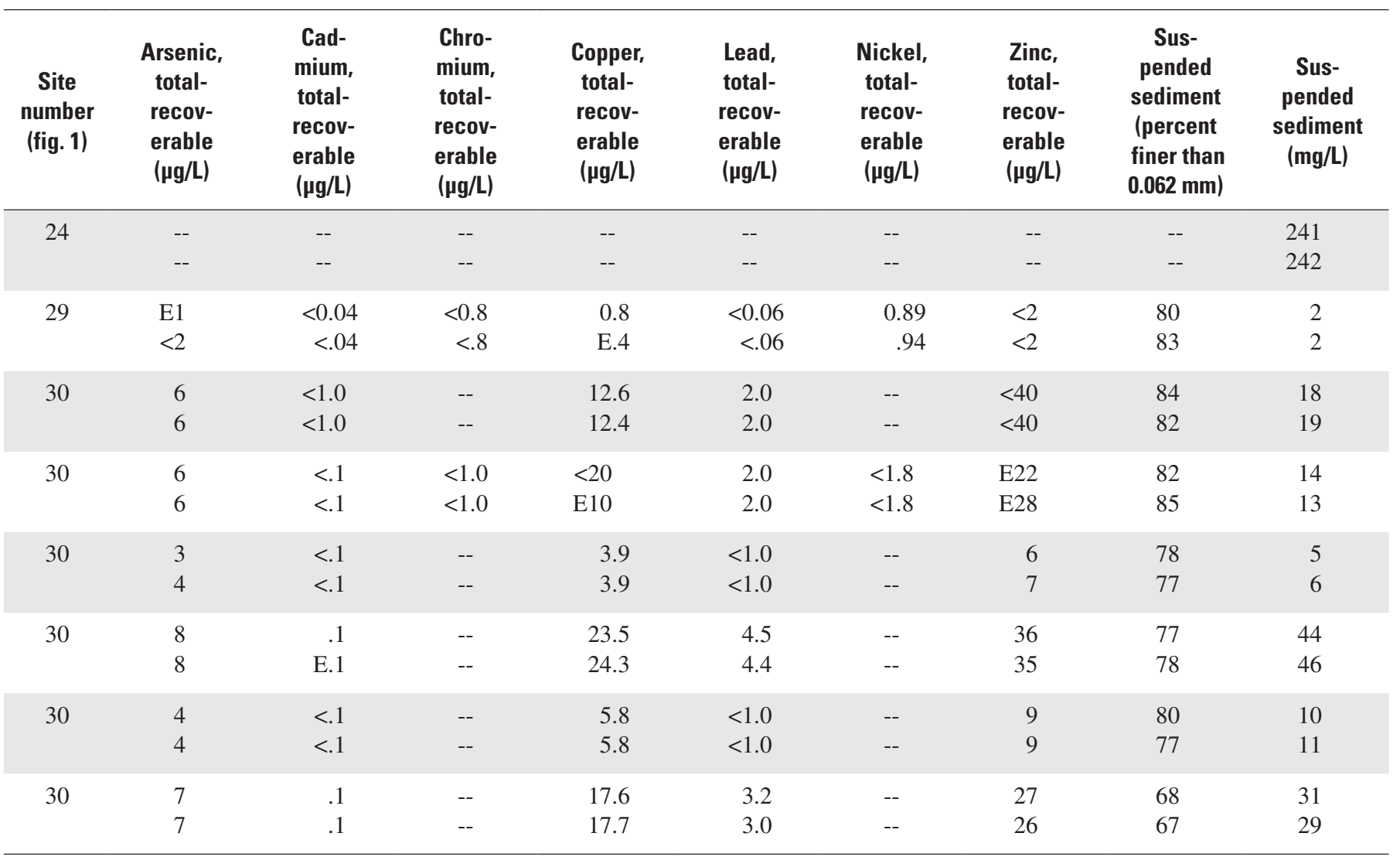


Table 14. Analytical results for blank samples from sites in the statewide monitoring network in Montana, water years 1999-2003.

[Constituent concentrations that equal or exceed twice the laboratory reporting level are in bold print. $\mathrm{Abbreviations:} \mathrm{CaCO}_{3}$, calcium carbonate; $\mu \mathrm{g} / \mathrm{L}$, micrograms per liter; mg/L milligrams per liter; N, nitrogen; P, phosphorus. Symbols: <, less than laboratory reporting level; --, no data]

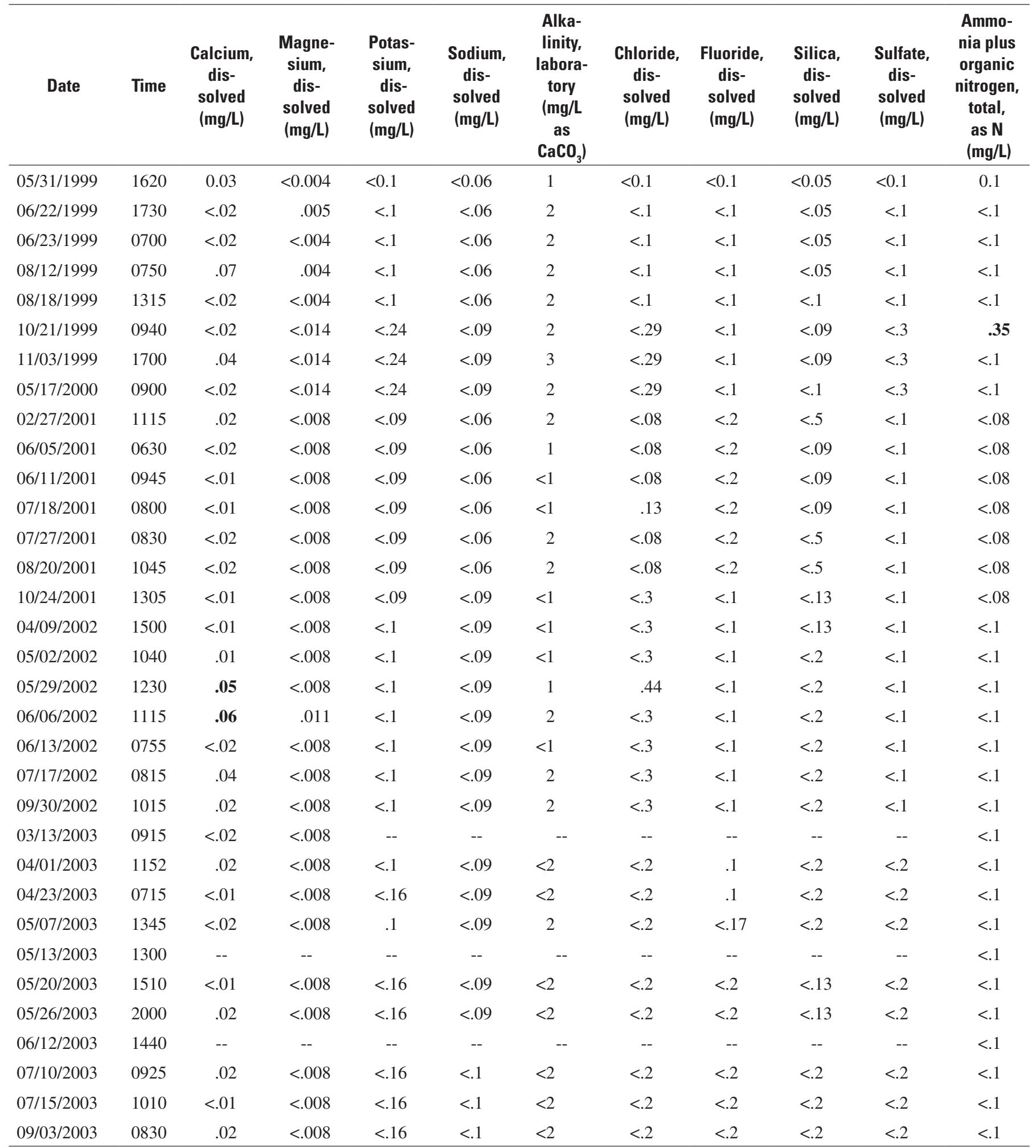


Table 14. Analytical results for blank samples from sites in the statewide monitoring network in Montana, water years 1999-2003. -Continued

\begin{tabular}{|c|c|c|c|c|c|c|c|c|c|c|c|}
\hline Date & $\begin{array}{l}\text { Nitrite } \\
\text { plus } \\
\text { nitrate, } \\
\text { dis- } \\
\text { solved, } \\
\text { as N } \\
\text { (mg/L) }\end{array}$ & $\begin{array}{l}\text { Nitrite, } \\
\text { dis- } \\
\text { solved, } \\
\text { as N } \\
\text { (mg/L) }\end{array}$ & $\begin{array}{c}\text { Ortho- } \\
\text { phos- } \\
\text { phate, } \\
\text { as } P \\
\text { (mg/L) }\end{array}$ & $\begin{array}{l}\text { Phos- } \\
\text { phorus, } \\
\text { total } \\
\text { as } P \\
\text { (mg/L) }\end{array}$ & $\begin{array}{c}\text { Arsenic, } \\
\text { total- } \\
\text { recov- } \\
\text { erable } \\
\text { ( } \mu \mathrm{g} / \mathrm{L})\end{array}$ & $\begin{array}{c}\text { Cad- } \\
\text { mium, } \\
\text { total- } \\
\text { recov- } \\
\text { erable } \\
\text { ( } \mu \mathrm{g} / \mathrm{L} \text { ) }\end{array}$ & $\begin{array}{l}\text { Chro- } \\
\text { mium, } \\
\text { total- } \\
\text { recov- } \\
\text { erable } \\
\text { ( } \mu \mathrm{g} / \mathrm{L} \text { ) }\end{array}$ & $\begin{array}{c}\text { Copper, } \\
\text { total- } \\
\text { recov- } \\
\text { erable } \\
(\mu \mathrm{g} / \mathrm{L})\end{array}$ & $\begin{array}{l}\text { Lead, } \\
\text { total- } \\
\text { recov- } \\
\text { erable } \\
\text { ( } \mu \mathrm{g} / \mathrm{L} \text { ) }\end{array}$ & $\begin{array}{c}\text { Nickel, } \\
\text { total- } \\
\text { recov- } \\
\text { erable } \\
\text { ( } \mu \mathrm{g} / \mathrm{L})\end{array}$ & $\begin{array}{l}\text { Zinc, } \\
\text { total- } \\
\text { recov- } \\
\text { erable } \\
(\mu \mathrm{g} / \mathrm{L})\end{array}$ \\
\hline 06/23/1999 & $<.05$ & $<.01$ & $<.001$ & $<.004$ & $<1$ & $<1$ & $<1$ & $<1$ & $<1$ & $<1$ & $<40$ \\
\hline 08/12/1999 & .007 & $<.001$ & $<.001$ & $<.004$ & $<1$ & $<1$ & $<1$ & $<1$ & $<1$ & $<1$ & $<40$ \\
\hline 08/18/1999 & $<.005$ & $<.001$ & $<.001$ & $<.004$ & $<1$ & $<1$ & $<1$ & $<1$ & $<1$ & $<1$ & $<40$ \\
\hline 10/21/1999 & $<.005$ & .001 & $<.001$ & $<.004$ & $<3$ & $<.1$ & $<1$ & $<1.2$ & $<1$ & $<1.8$ & $<31$ \\
\hline 06/05/2001 & .006 & $<.001$ & $<.007$ & $<.004$ & $<2$ & $<.1$ & $<1$ & $<.6$ & $<1$ & $<2$ & $<1$ \\
\hline $06 / 11 / 2001$ & $<.005$ & $<.001$ & $<.007$ & $<.004$ & $<2$ & $<.1$ & $<1$ & $<.6$ & $<1$ & $<1$ & $<1$ \\
\hline 07/18/2001 & .006 & $<.001$ & $<.007$ & .004 & $<2$ & $<.1$ & $<1$ & $<.6$ & $<1$ & $<1$ & $<1$ \\
\hline $07 / 27 / 2001$ & .005 & $<.001$ & $<.007$ & $<.004$ & $<2$ & $<.1$ & $<1$ & $<.6$ & $<1$ & $<1$ & 1 \\
\hline 08/20/2001 & $<.005$ & $<.001$ & $<.007$ & $<.004$ & -- & -- & -- & -- & -- & -- & -- \\
\hline $10 / 24 / 2001$ & $<.013$ & $<.002$ & $<.007$ & $<.004$ & $<2$ & $<.1$ & $<.8$ & $<.6$ & $<1$ & $<1$ & $<1$ \\
\hline 04/09/2002 & $<.013$ & $<.002$ & $<.007$ & $<.004$ & $<2$ & $<.1$ & $<.8$ & $<.6$ & $<1$ & $<2$ & $<1$ \\
\hline 05/02/2002 & $<.013$ & $<.002$ & $<.007$ & $<.004$ & $<2$ & $<.04$ & $<.8$ & $<.6$ & $<1$ & $<1$ & $<1$ \\
\hline 03/13/2003 & $<.022$ & $<.002$ & $<.007$ & $<.004$ & $<2$ & $<.04$ & -- & $<.6$ & .12 & -- & 2 \\
\hline 04/01/2003 & $<.022$ & $<.002$ & $<.007$ & $<.004$ & $<2$ & $<.04$ & $<.8$ & $<.6$ & $<.06$ & $<.16$ & $<2$ \\
\hline $04 / 23 / 2003$ & $<.022$ & $<.002$ & $<.007$ & $<.004$ & $<2$ & $<.04$ & $<.8$ & $<.6$ & $<.06$ & $<.16$ & $<2$ \\
\hline 05/07/2003 & $<.022$ & $<.002$ & $<.007$ & $<.004$ & $<2$ & $<.04$ & $<.8$ & $<.6$ & $<.06$ & $<.16$ & $<2$ \\
\hline 05/13/2003 & $<.022$ & -- & $<.007$ & $<.004$ & -- & -- & -- & -- & -- & -- & -- \\
\hline 05/20/2003 & $<.022$ & $<.002$ & $<.007$ & $<.004$ & $<2$ & $<.2$ & $<.8$ & $<.6$ & $<.06$ & $<.16$ & $<2$ \\
\hline $05 / 26 / 2003$ & $<.022$ & $<.002$ & $<.007$ & $<.004$ & $<2$ & $<.2$ & $<.8$ & $<.6$ & $<.06$ & $<.16$ & $<2$ \\
\hline $06 / 12 / 2003$ & $<.022$ & $<.002$ & $<.007$ & $<.004$ & -- & -- & -- & -- & -- & -- & -- \\
\hline 07/10/2003 & $<.022$ & $<.002$ & $<.007$ & $<.004$ & $<2$ & $<.2$ & $<.8$ & $<.6$ & $<.06$ & $<.16$ & $<2$ \\
\hline $07 / 15 / 2003$ & $<.022$ & -- & $<.007$ & $<.004$ & $<2$ & $<.04$ & $<.8$ & $<.6$ & .07 & $<.16$ & $<2$ \\
\hline 09/03/2003 & $<.022$ & $<.002$ & $<.007$ & $<.004$ & $<2$ & $<.04$ & $<.8$ & $<.6$ & $<.06$ & $<.16$ & $<2$ \\
\hline
\end{tabular}


Data 101

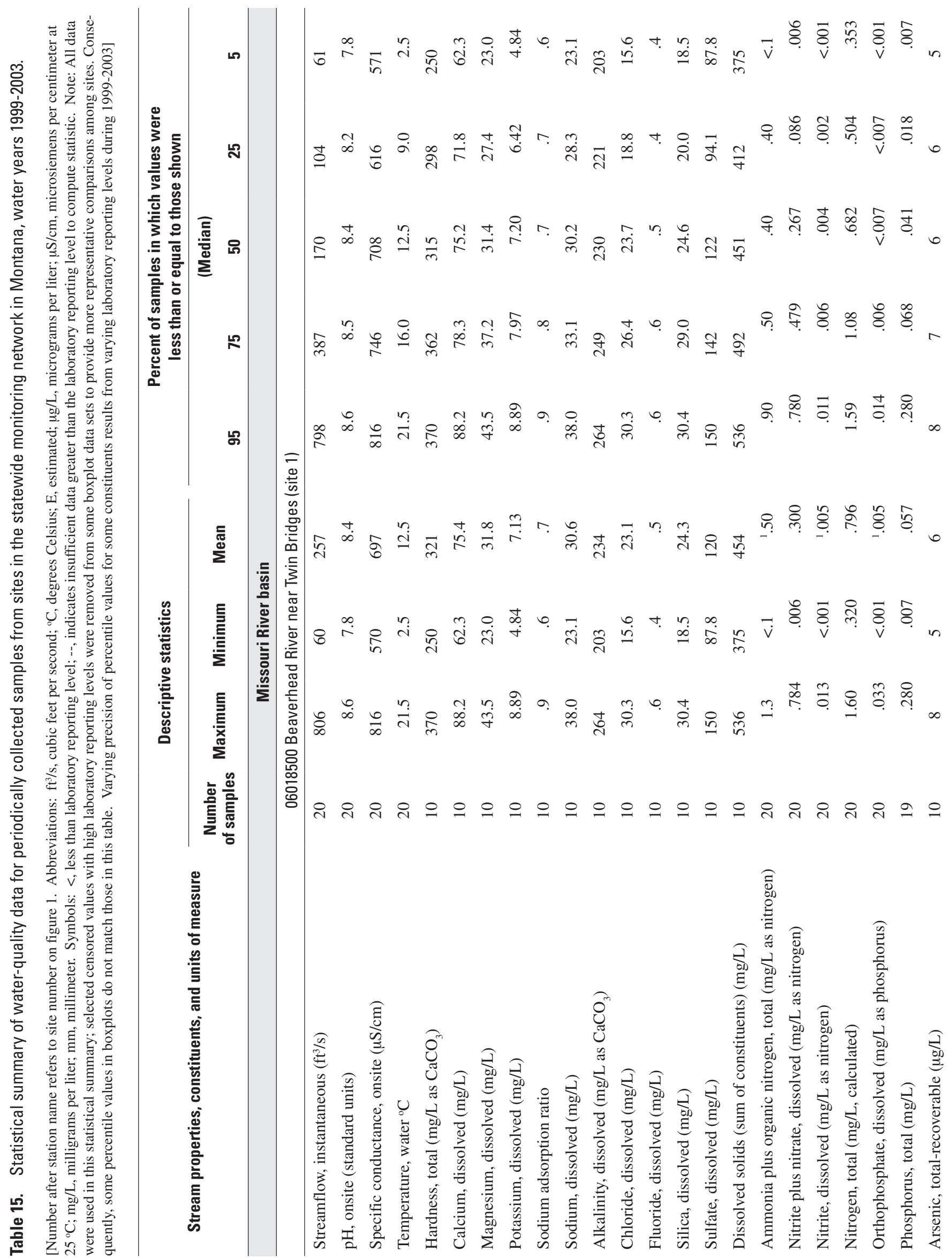




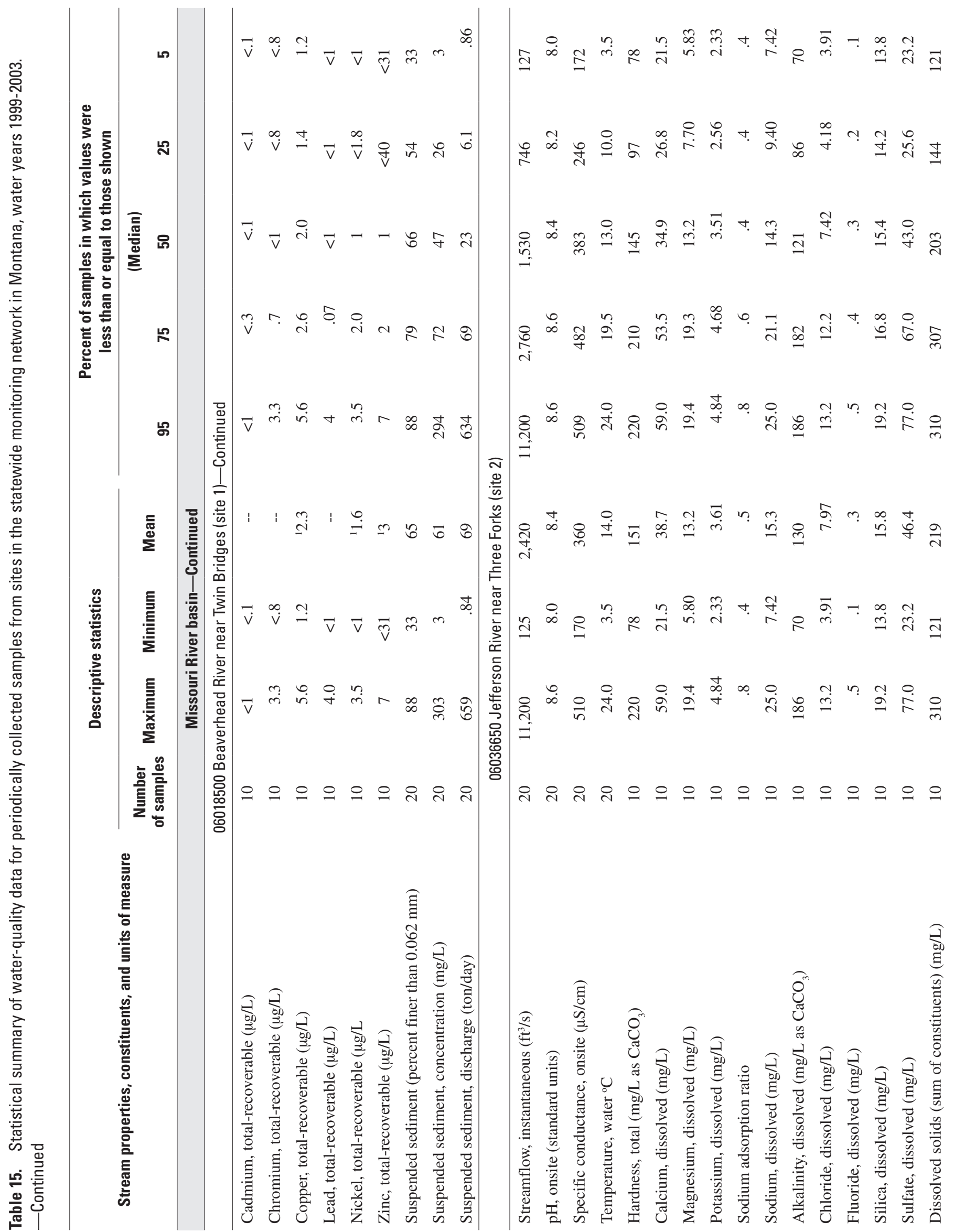




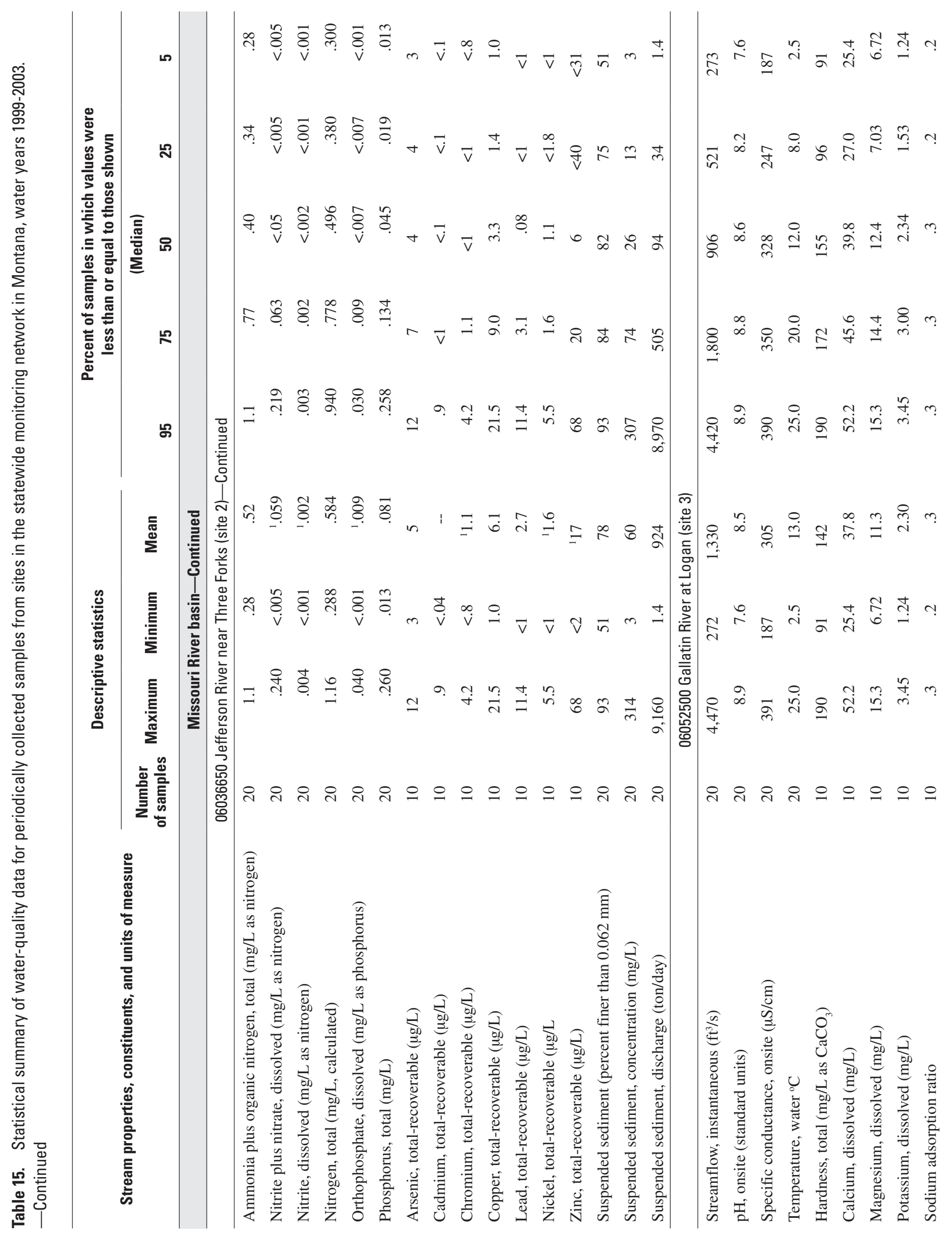




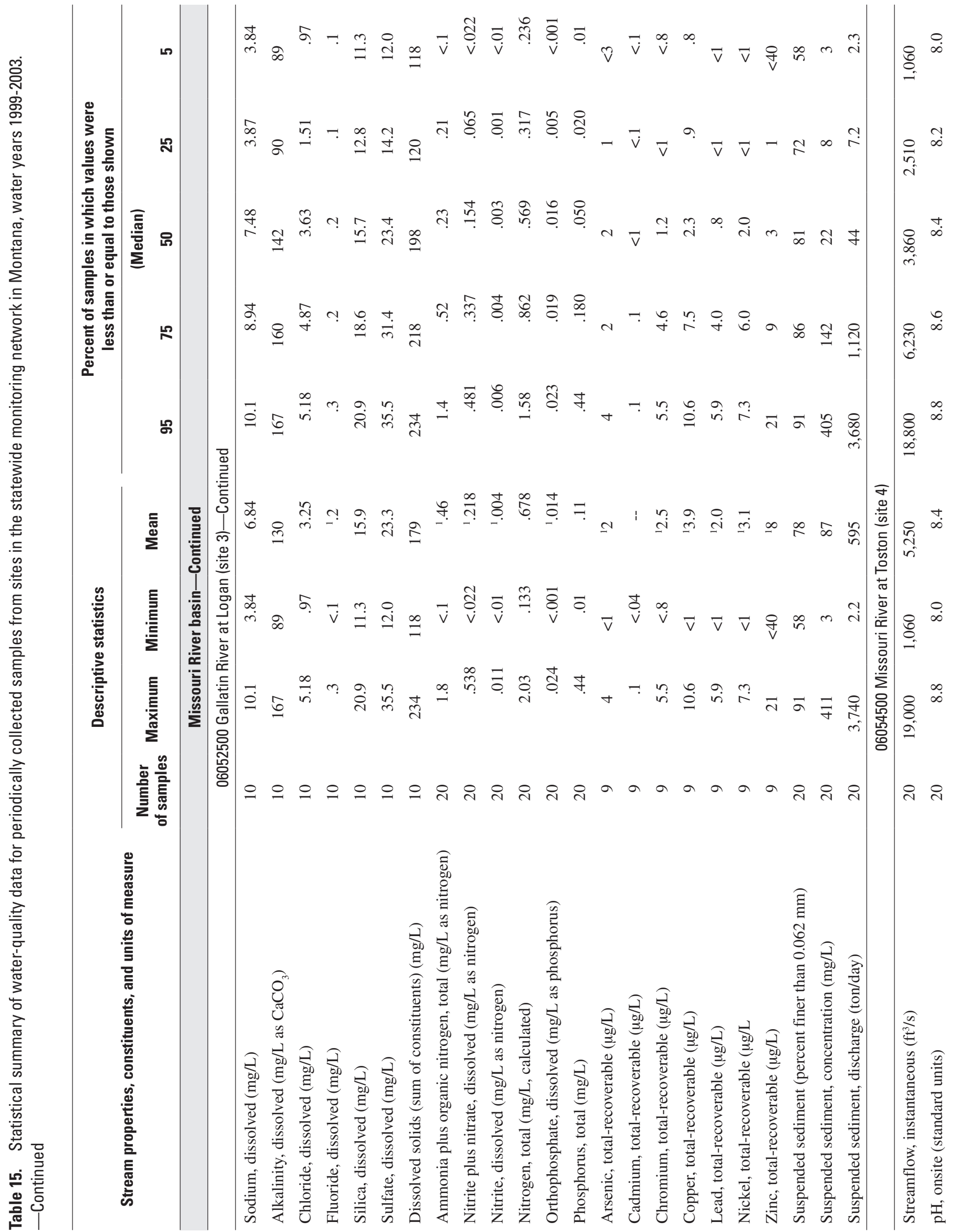




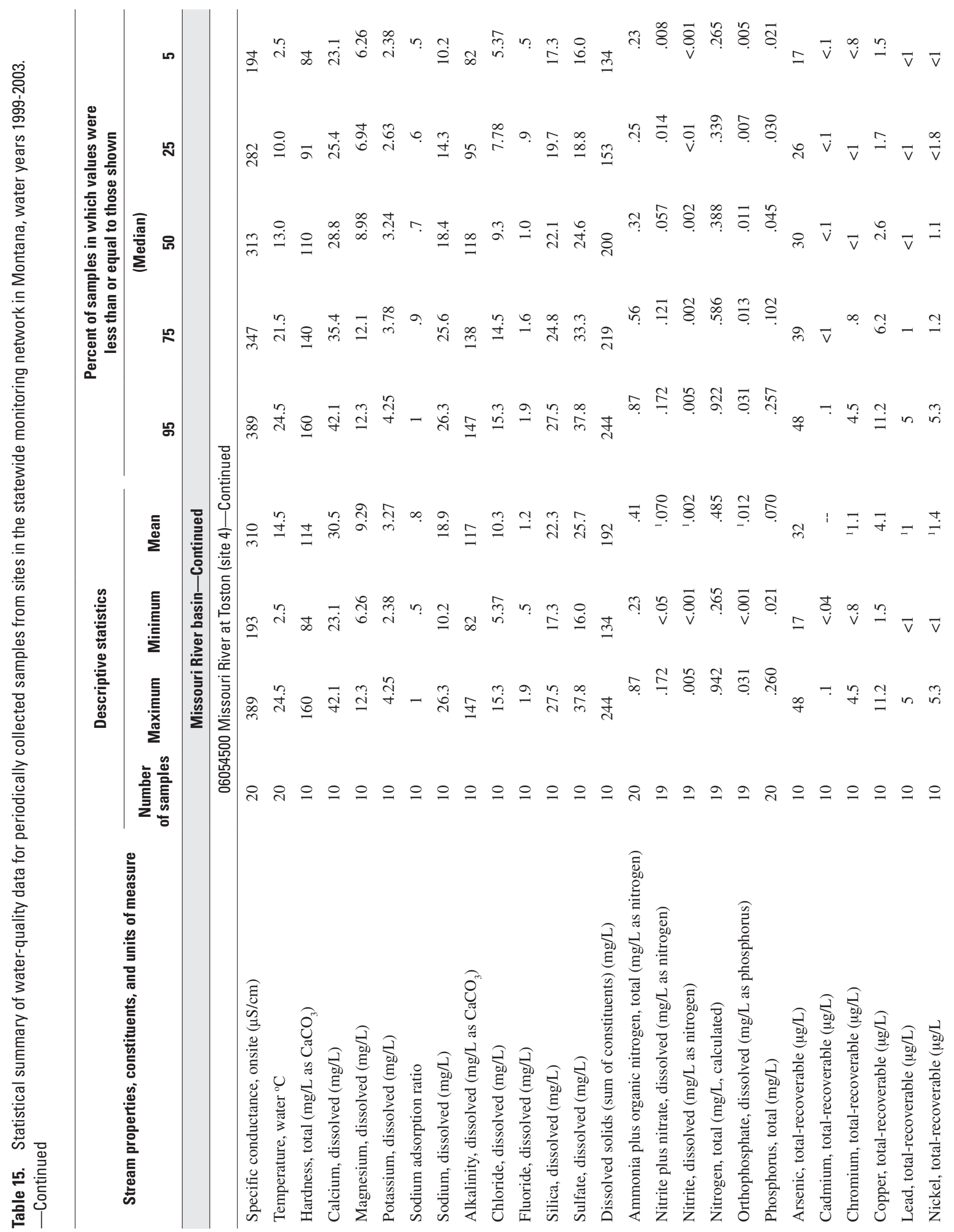




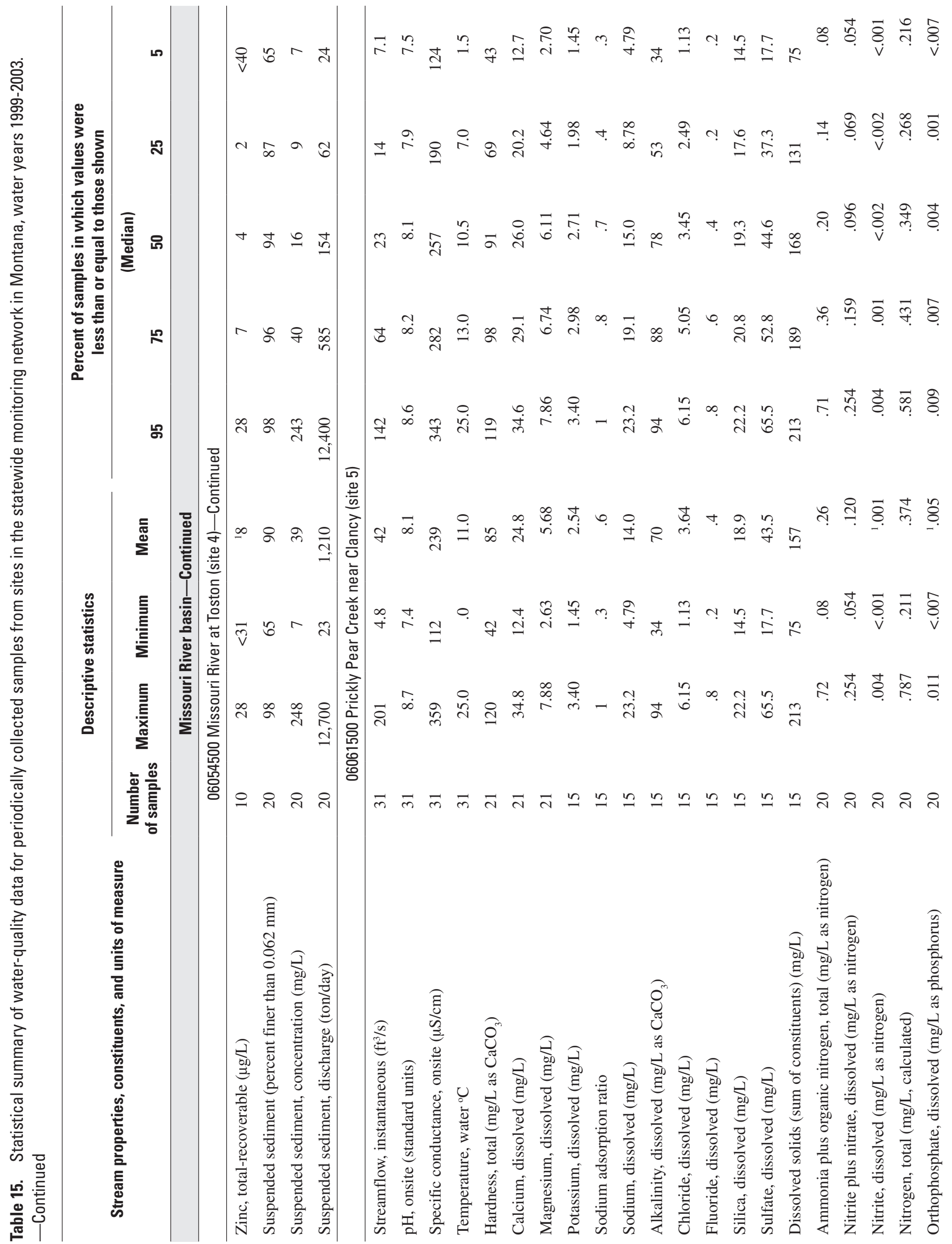




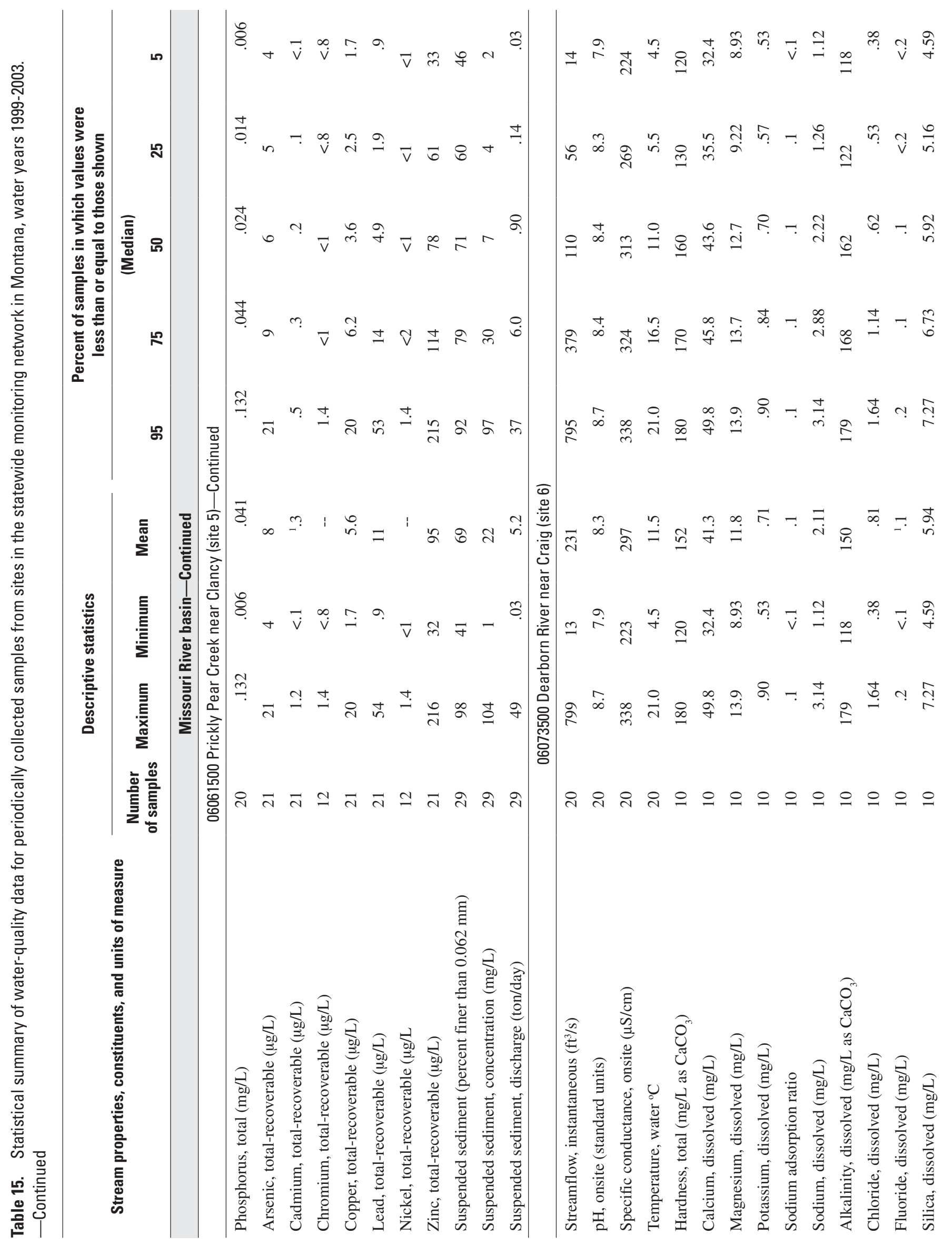




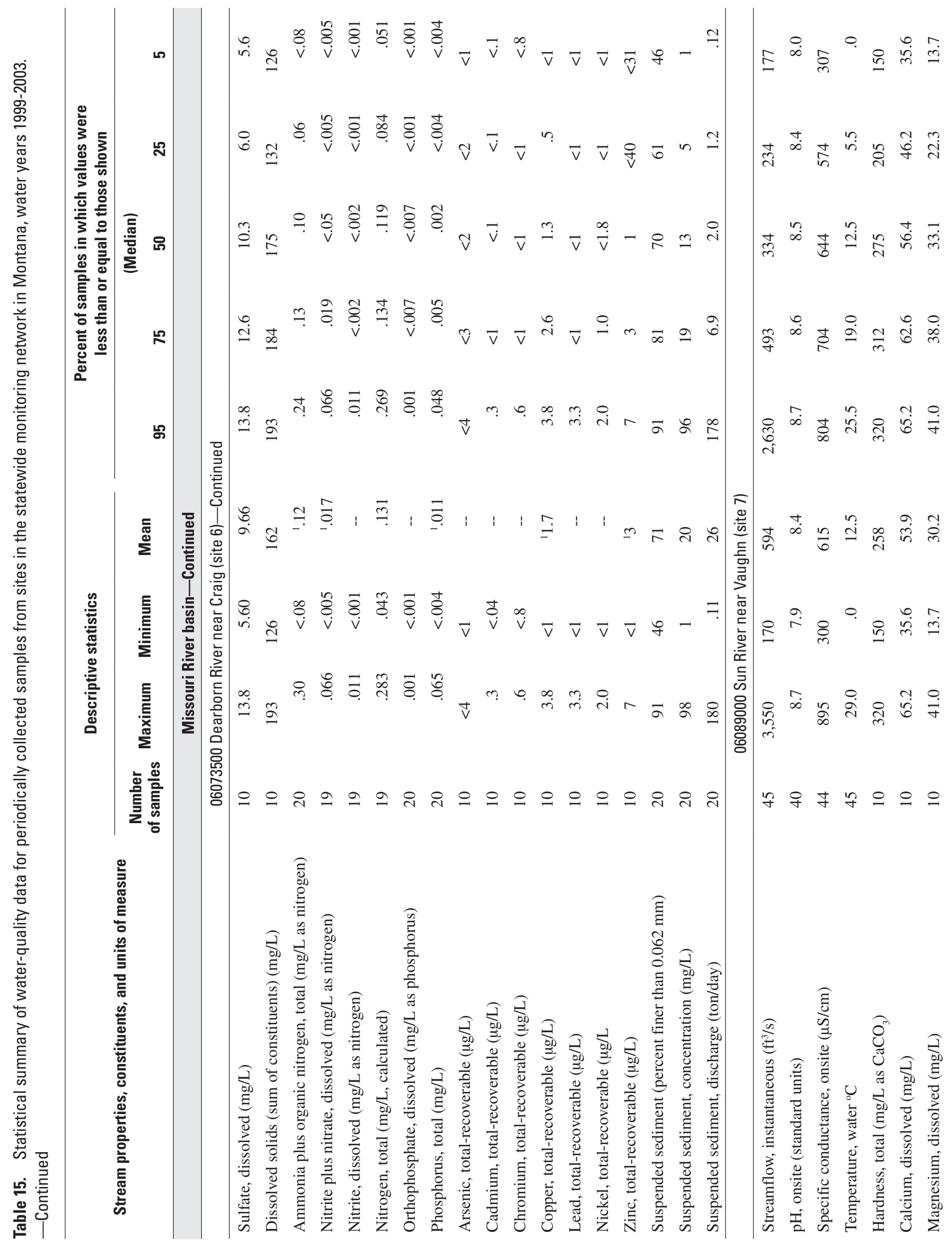




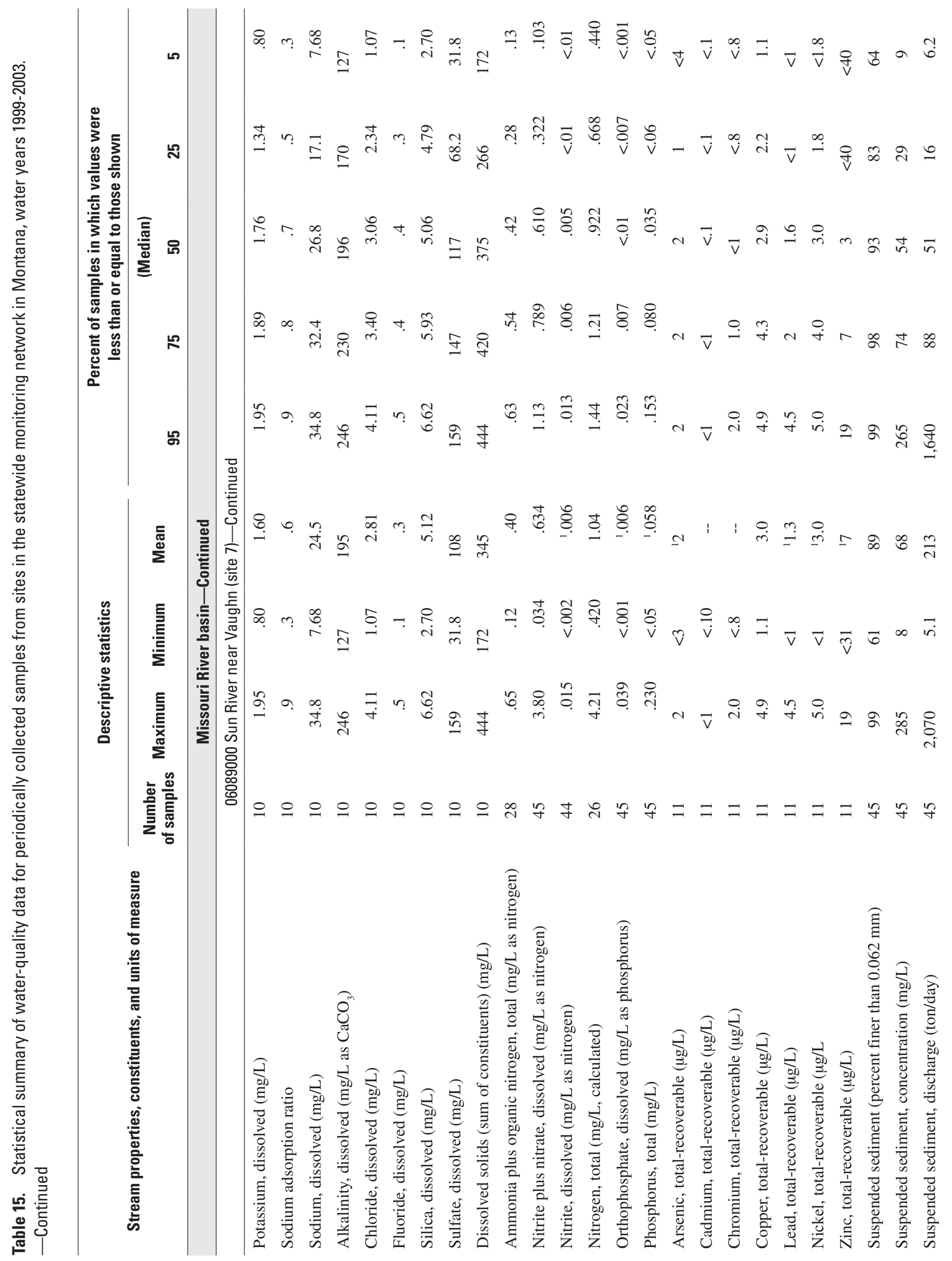




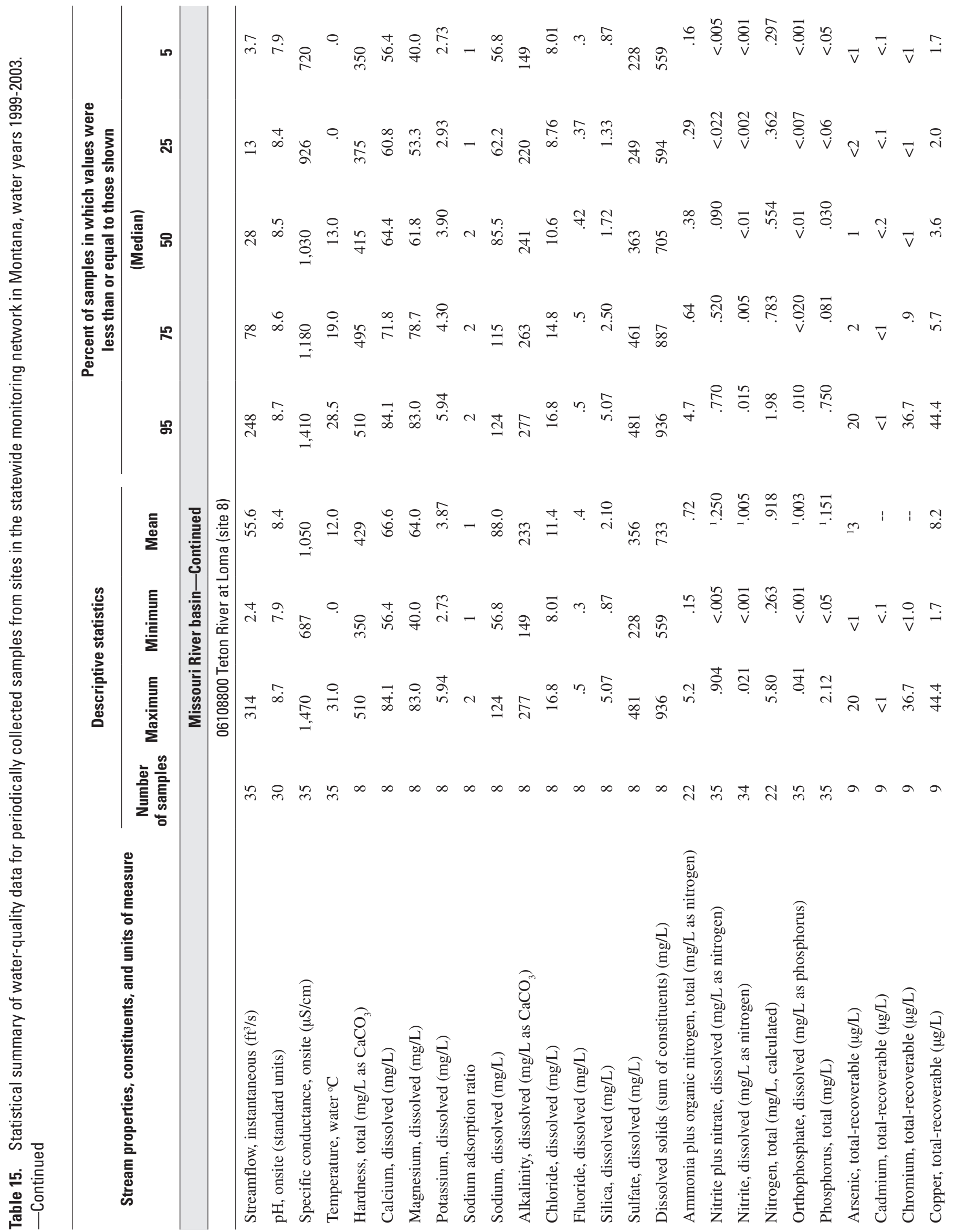


Data 111

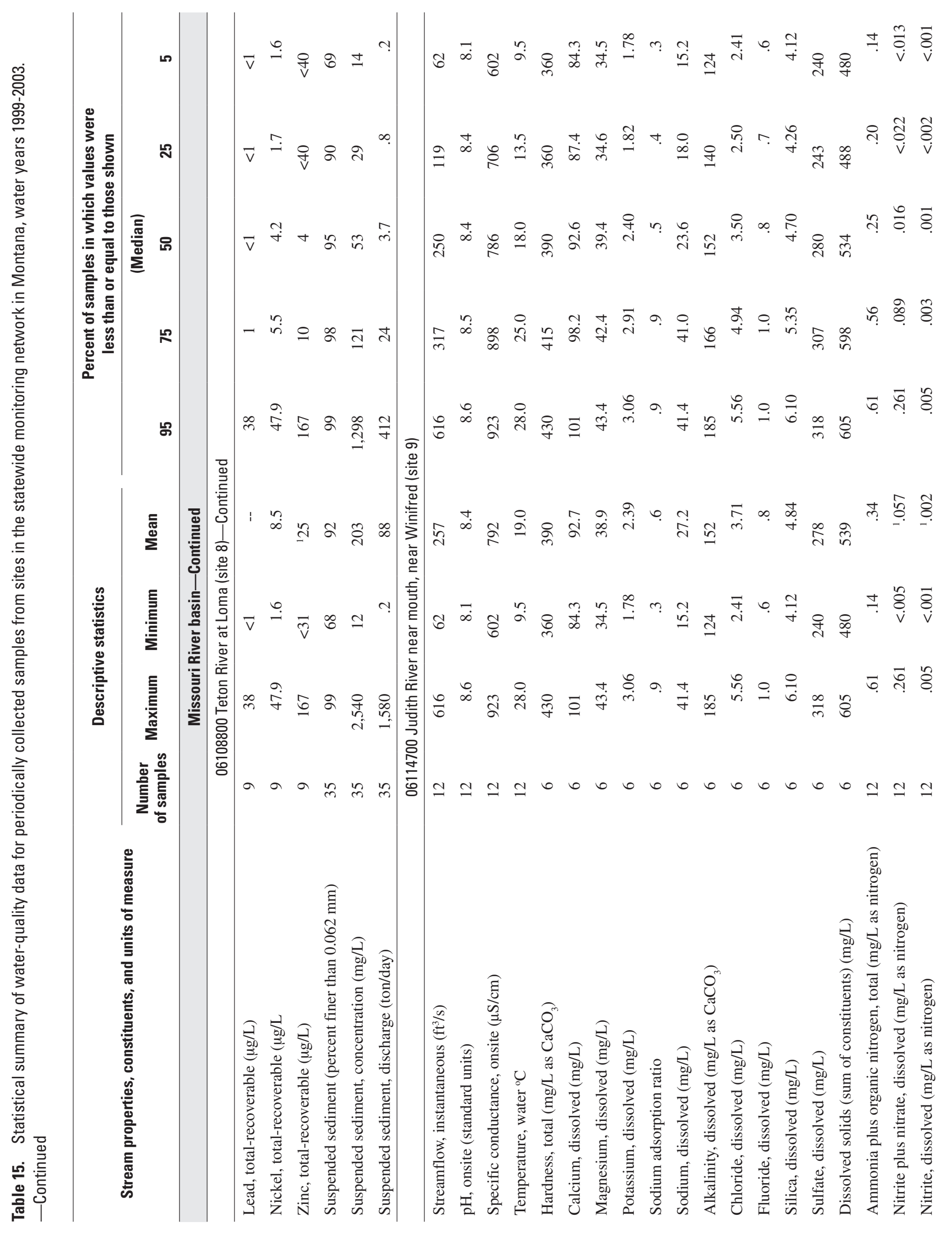




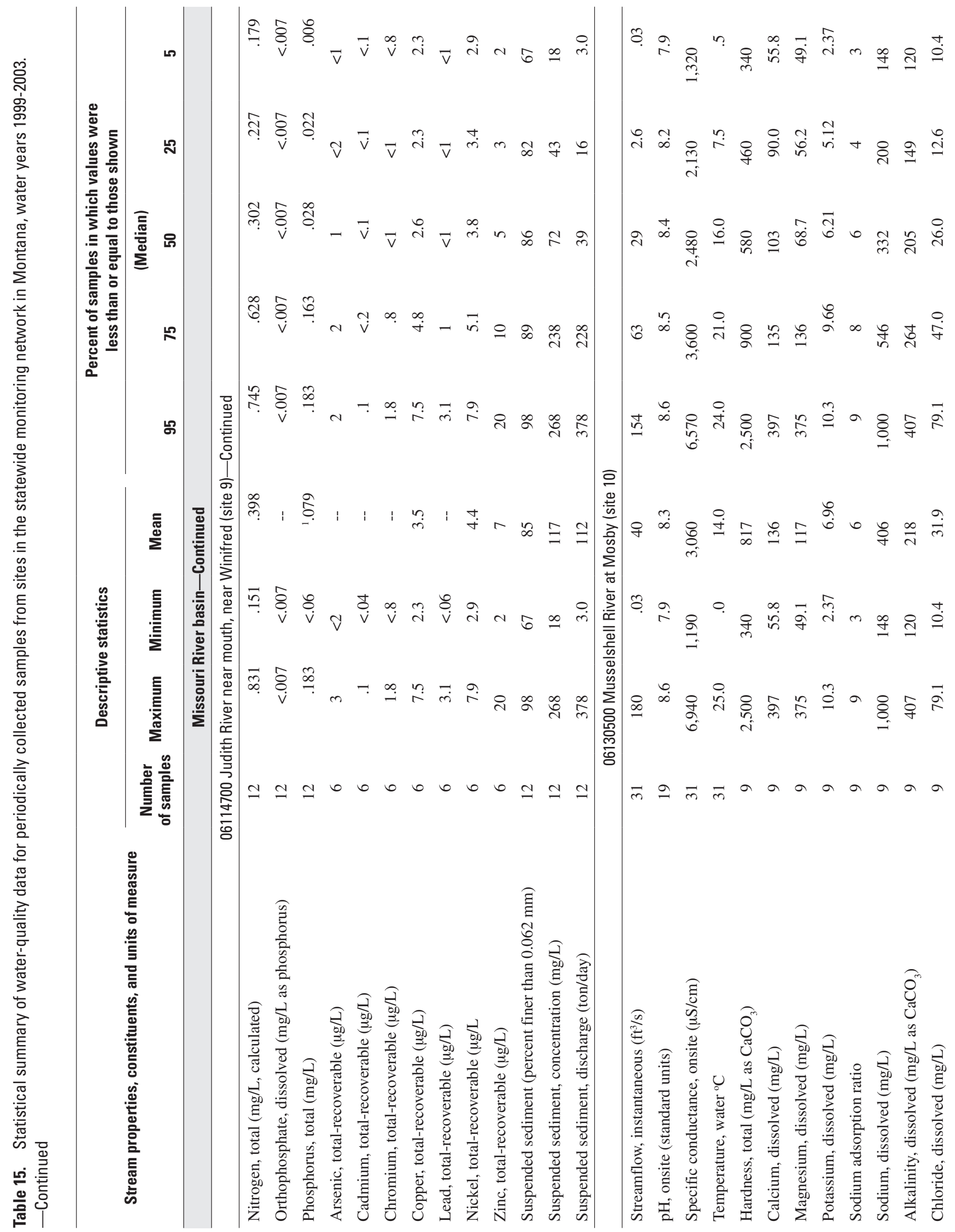


Data 113

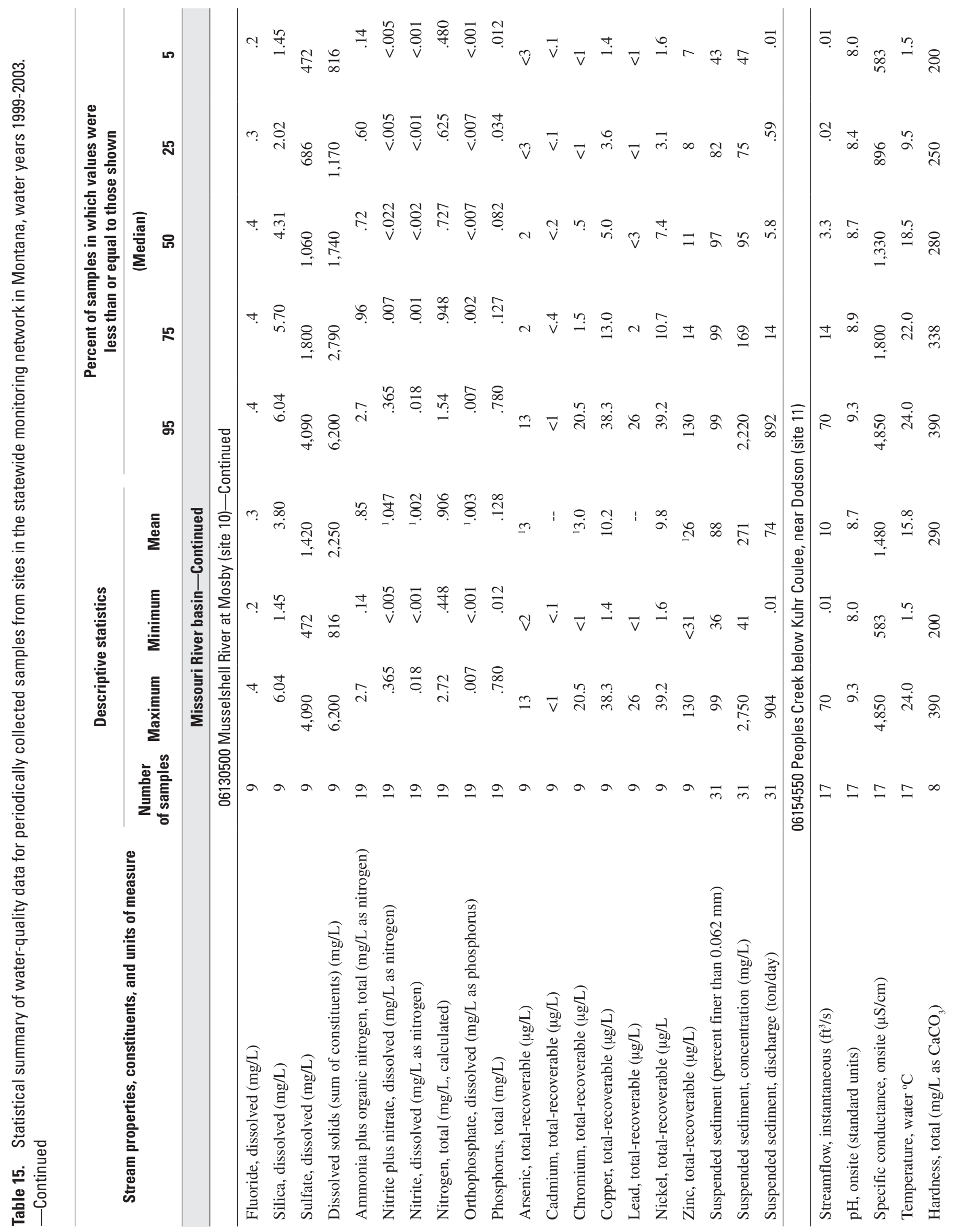




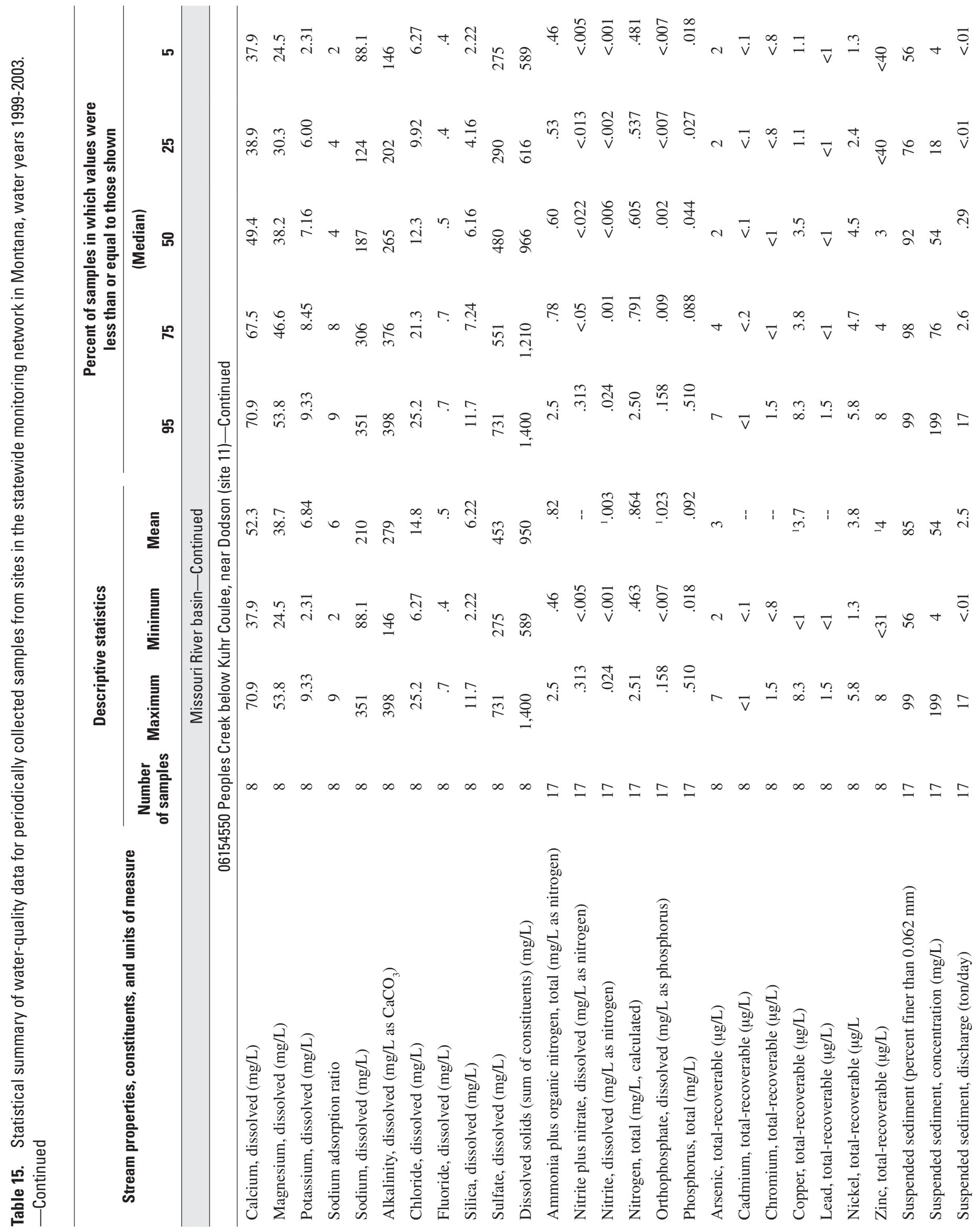




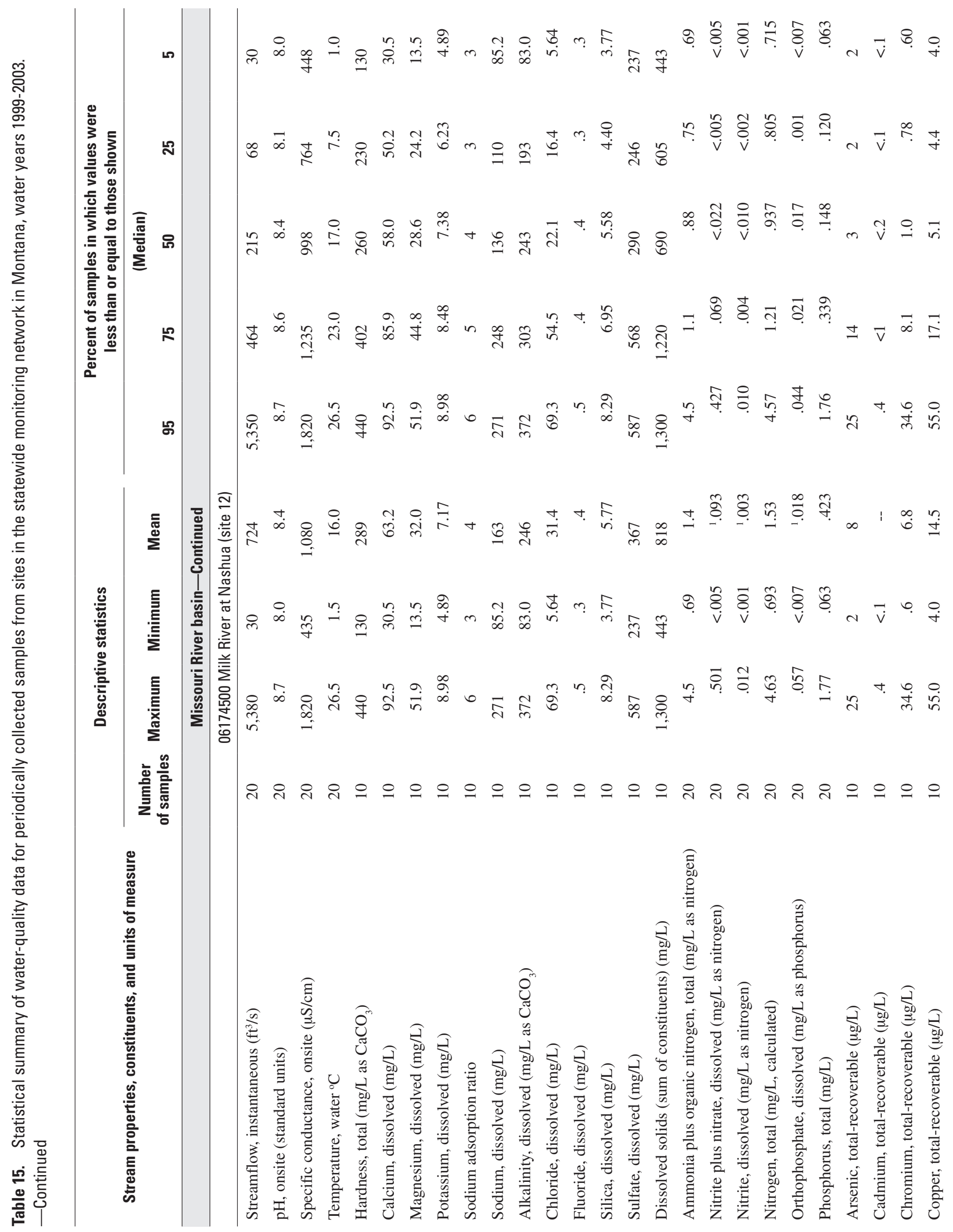




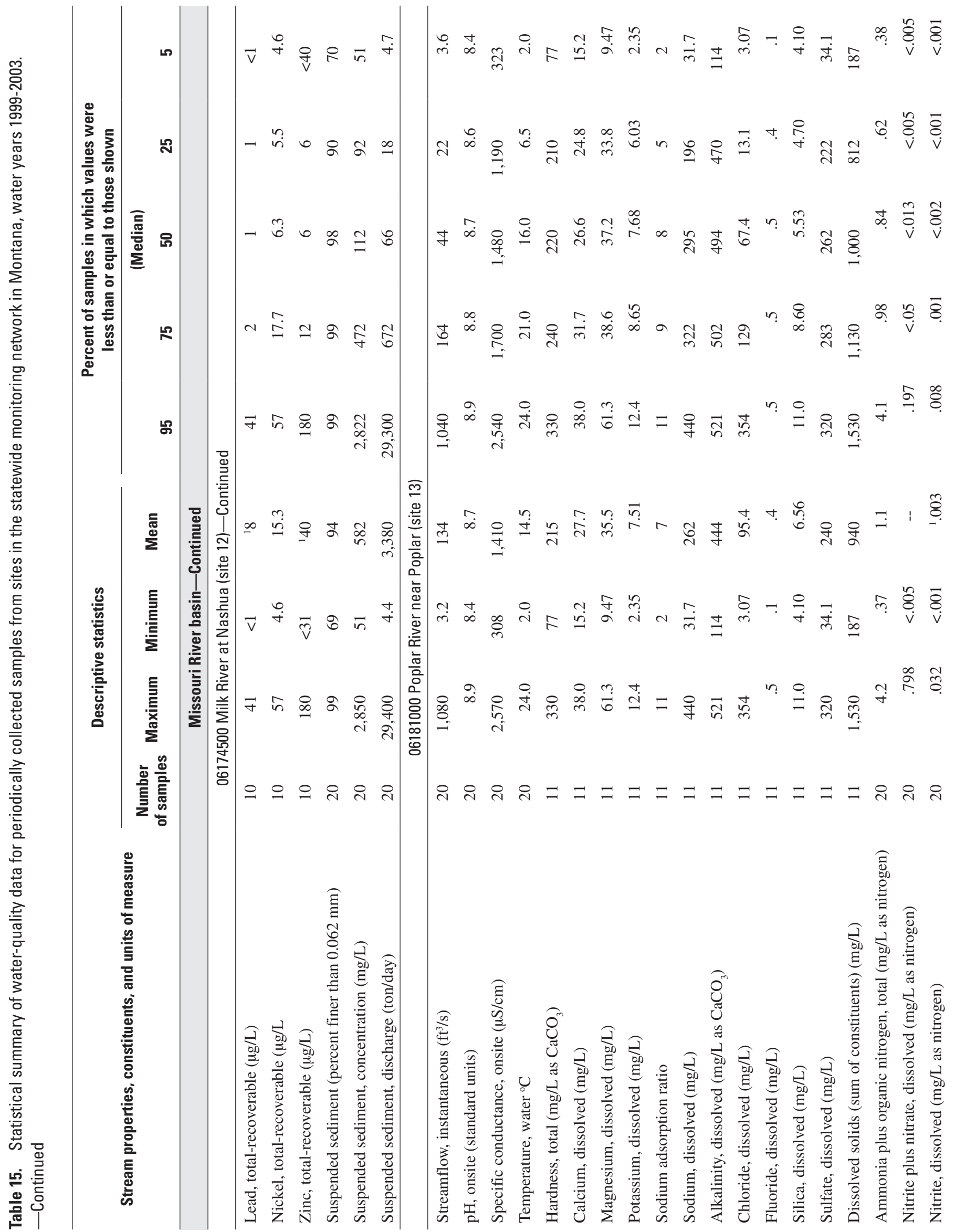




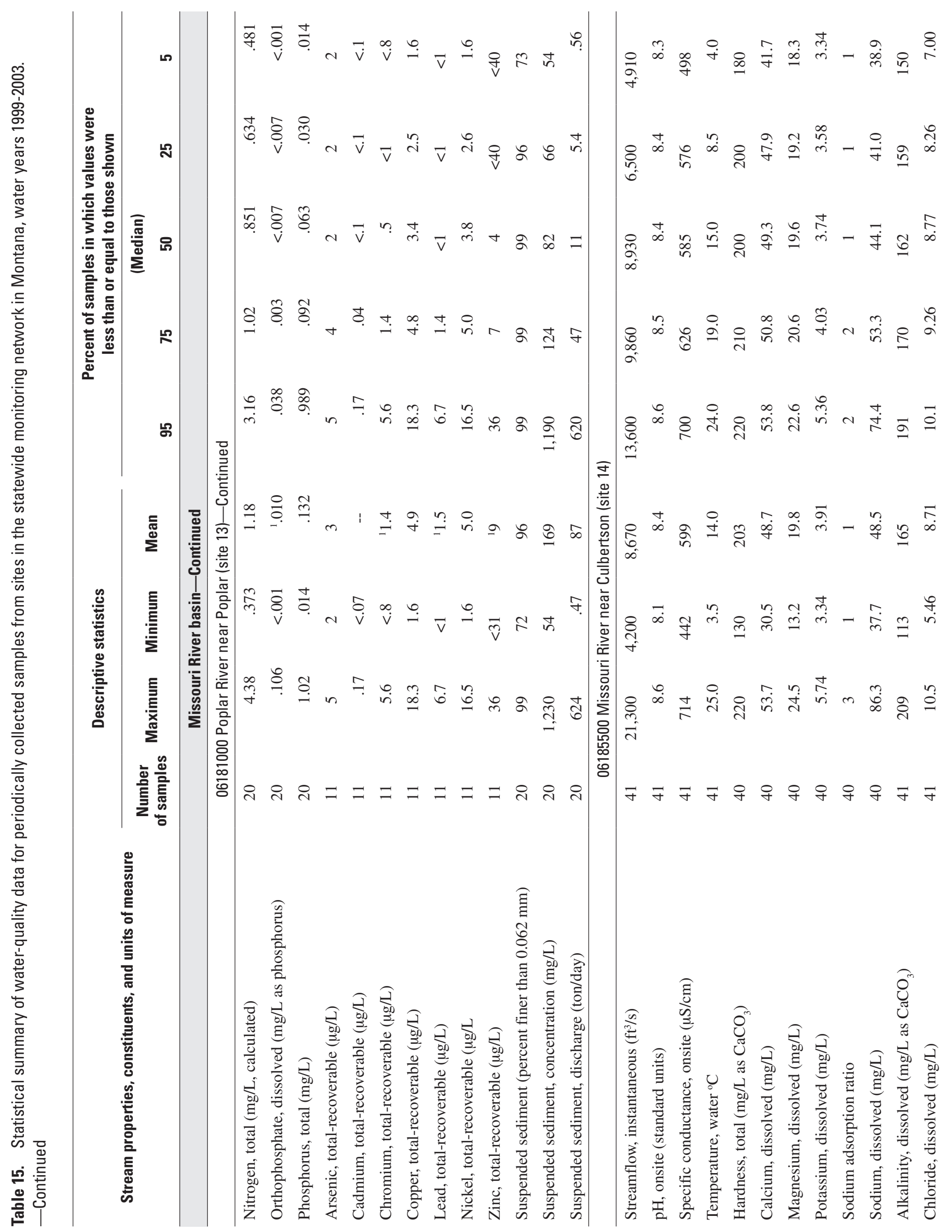




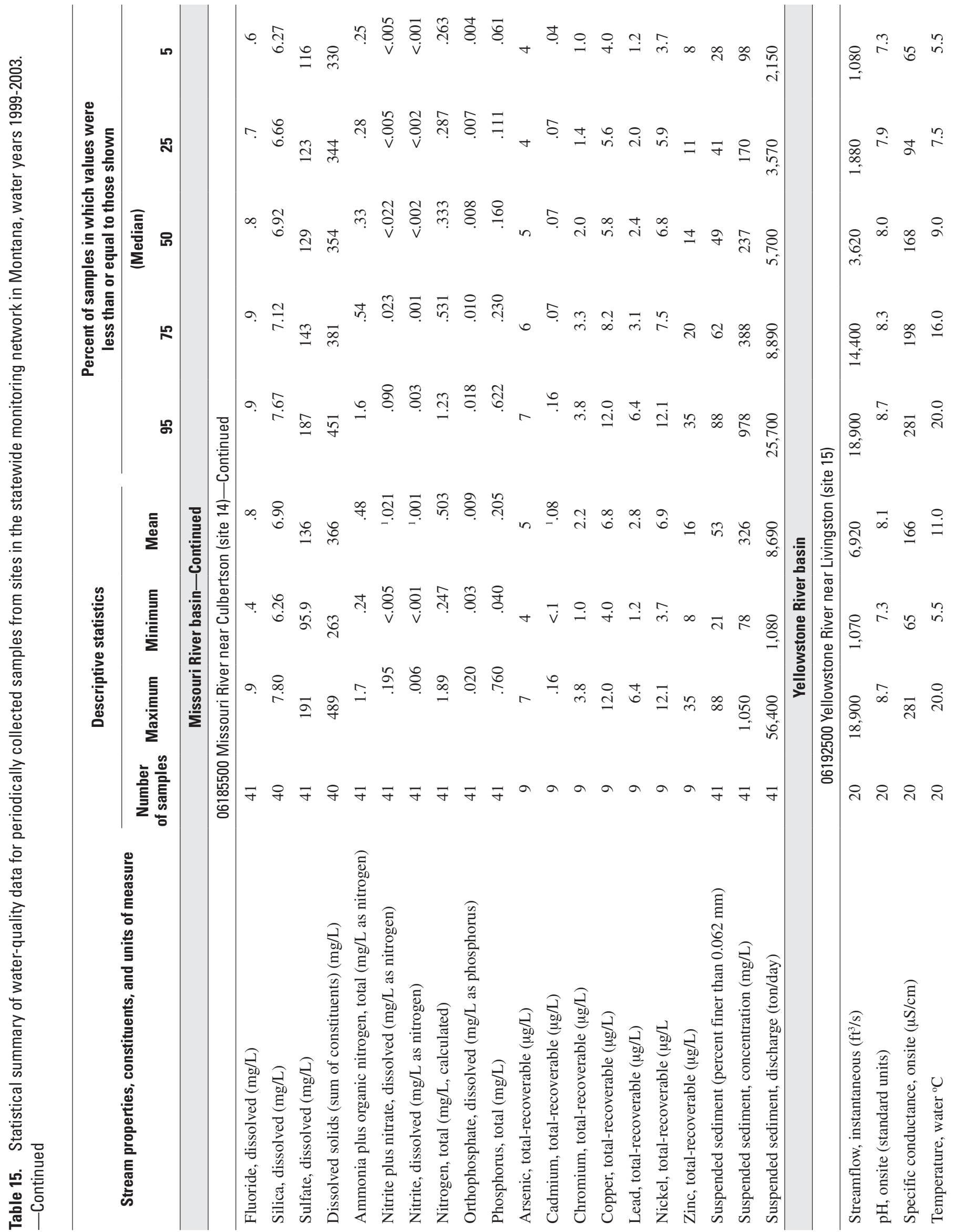




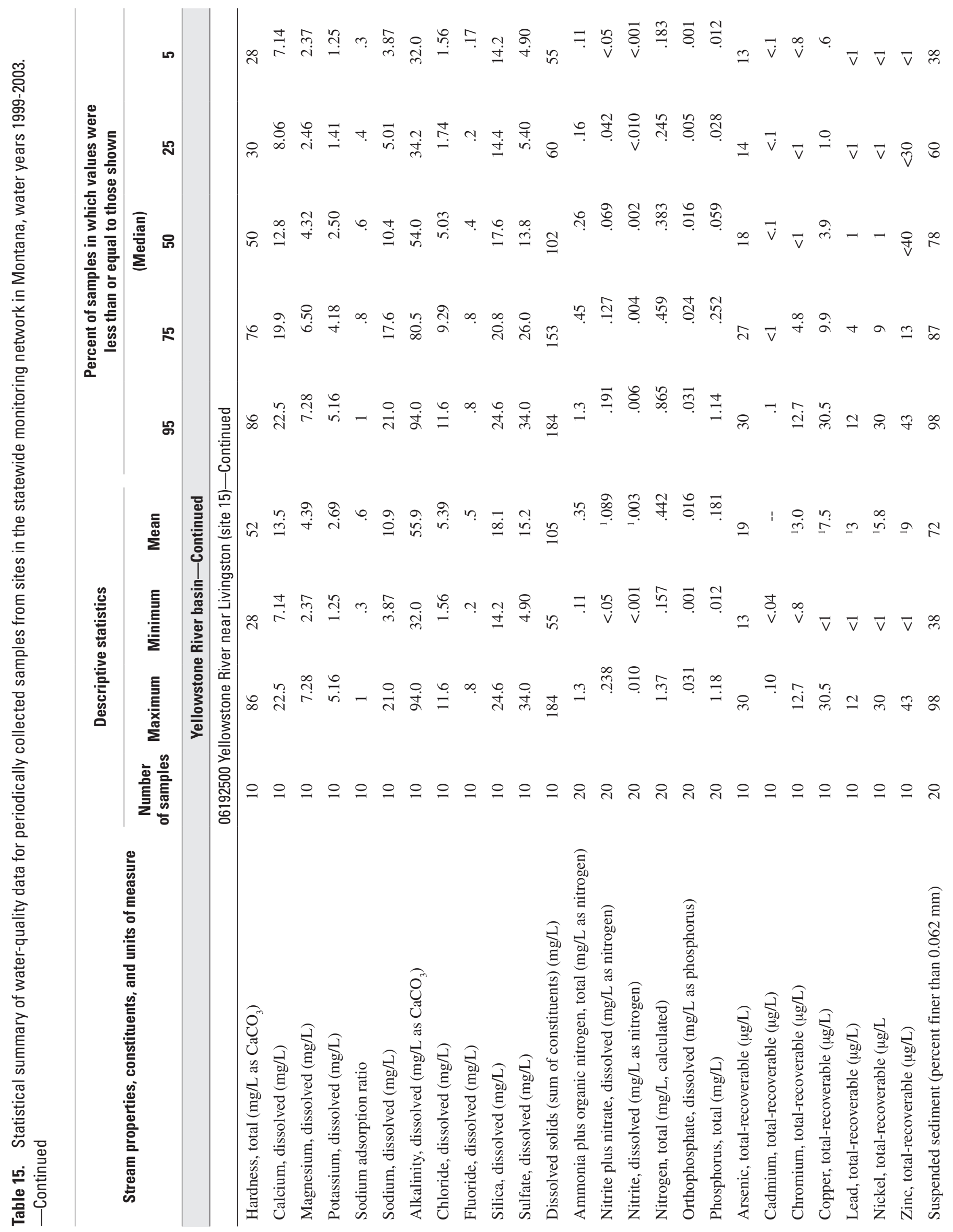




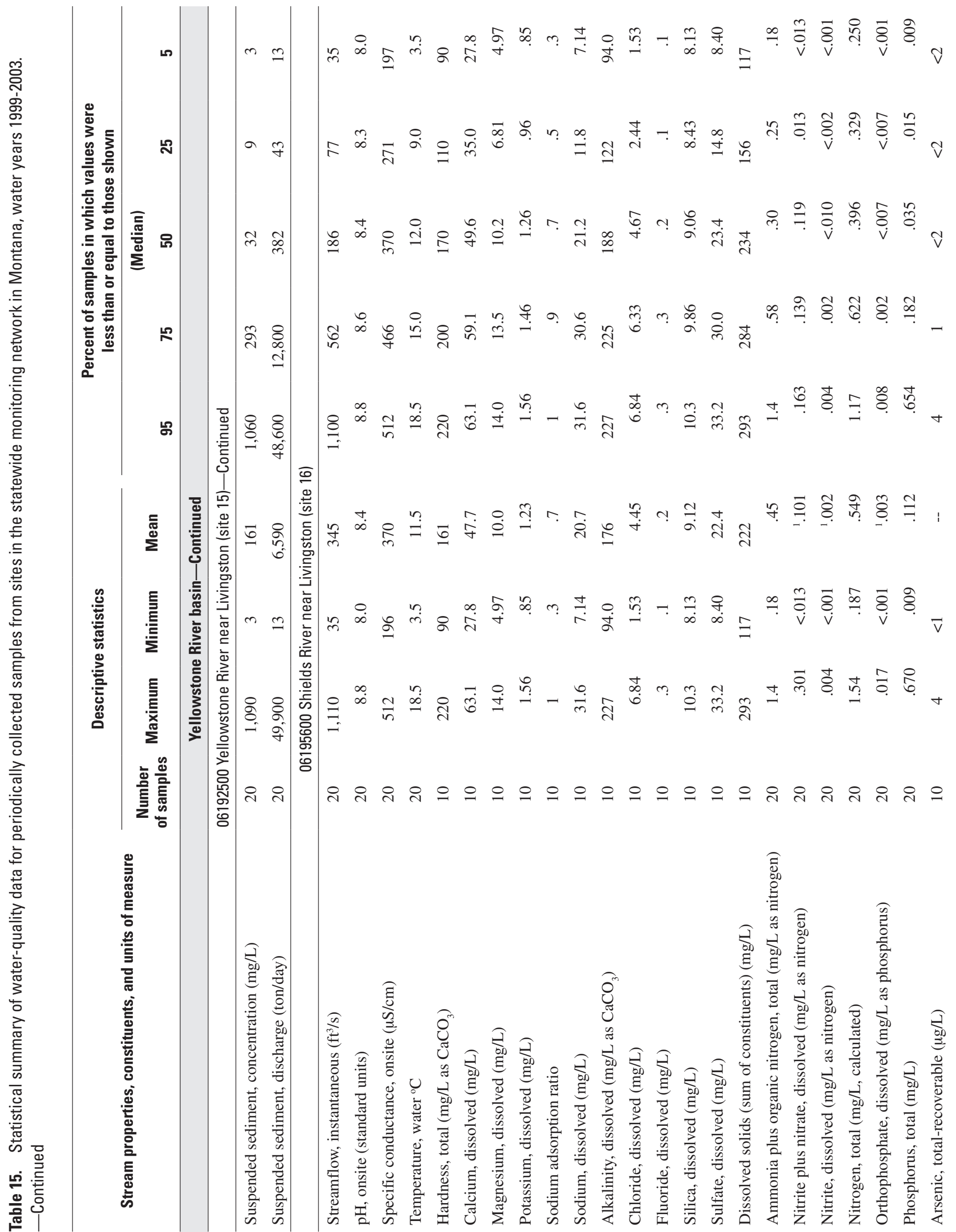




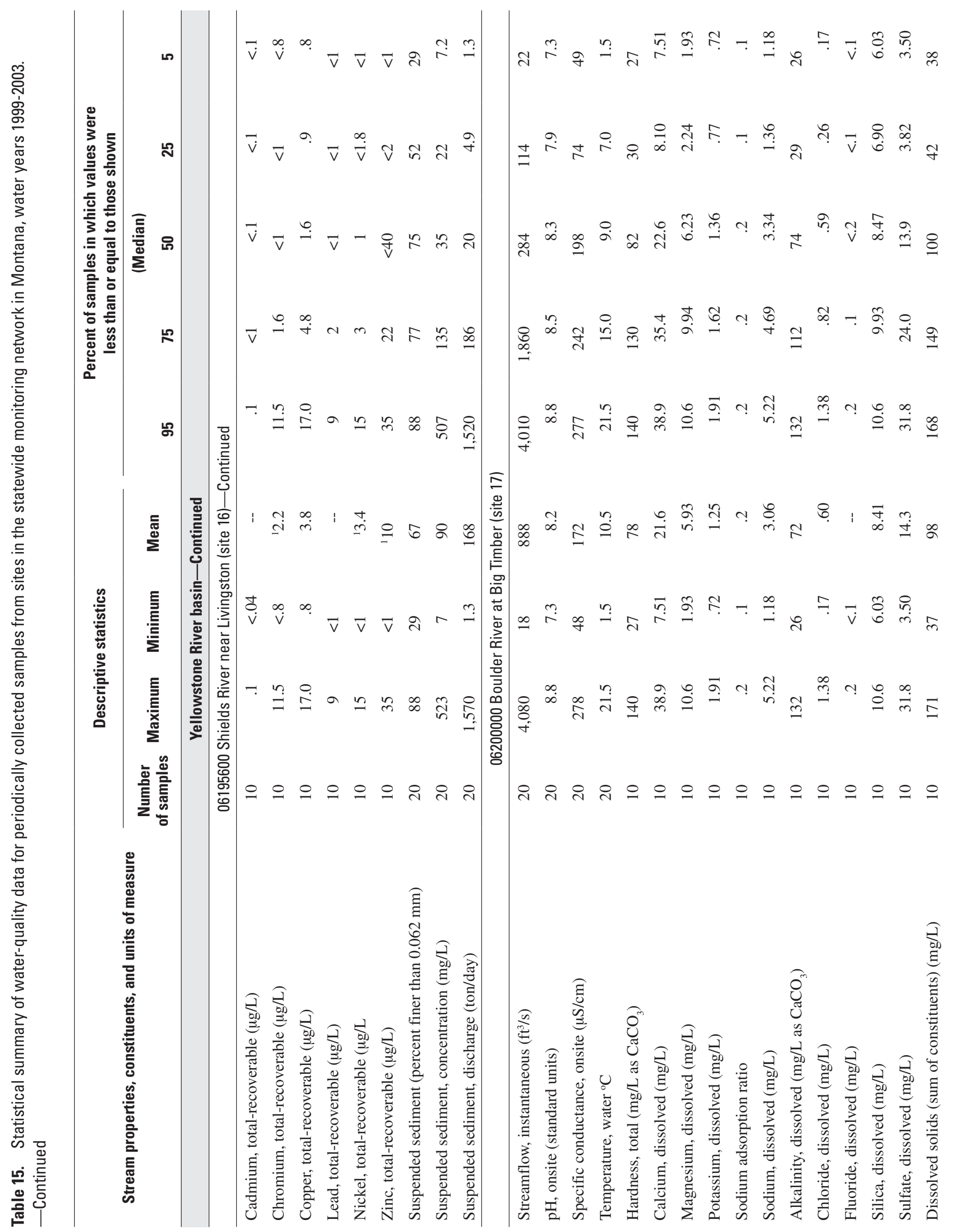




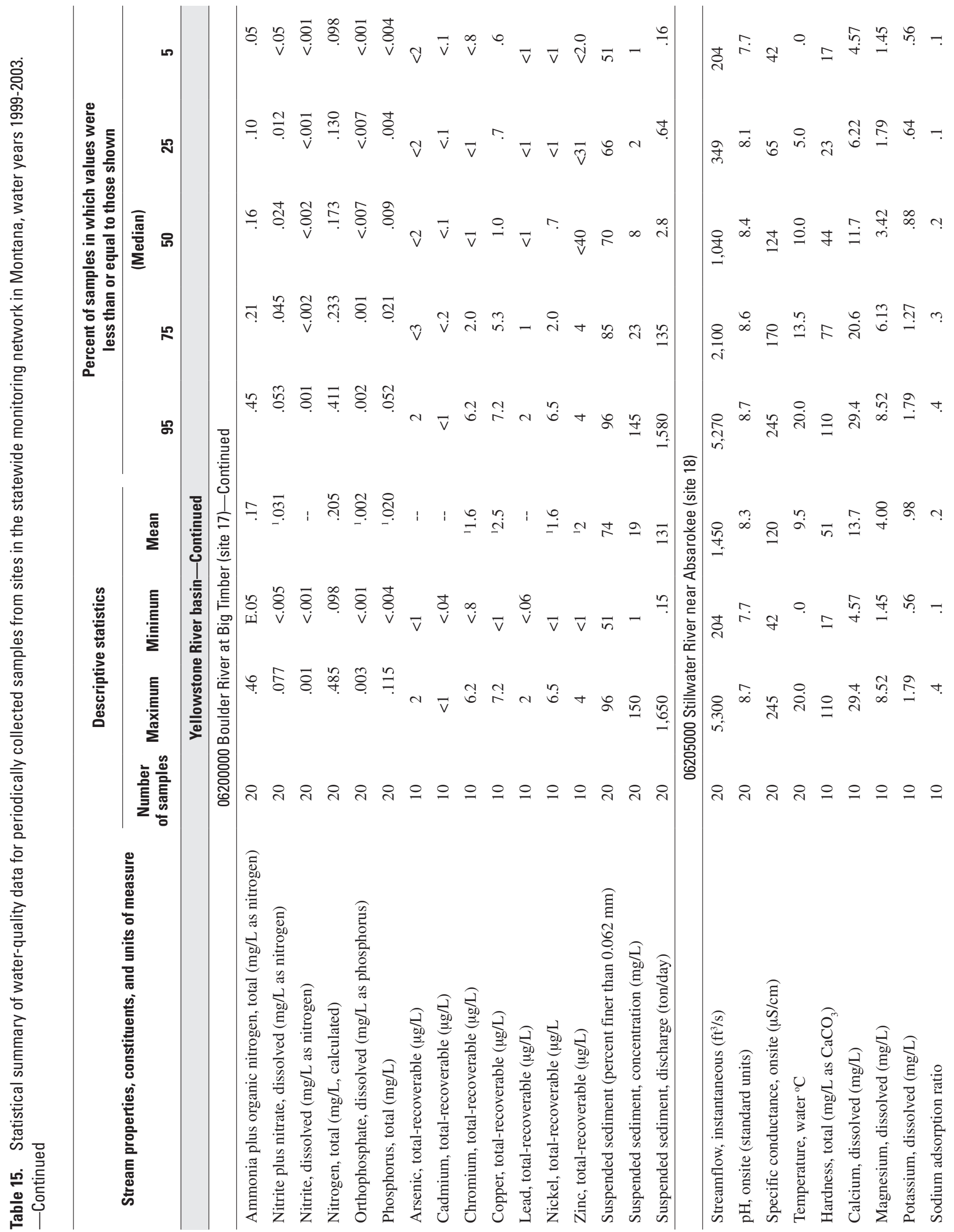


Data 123

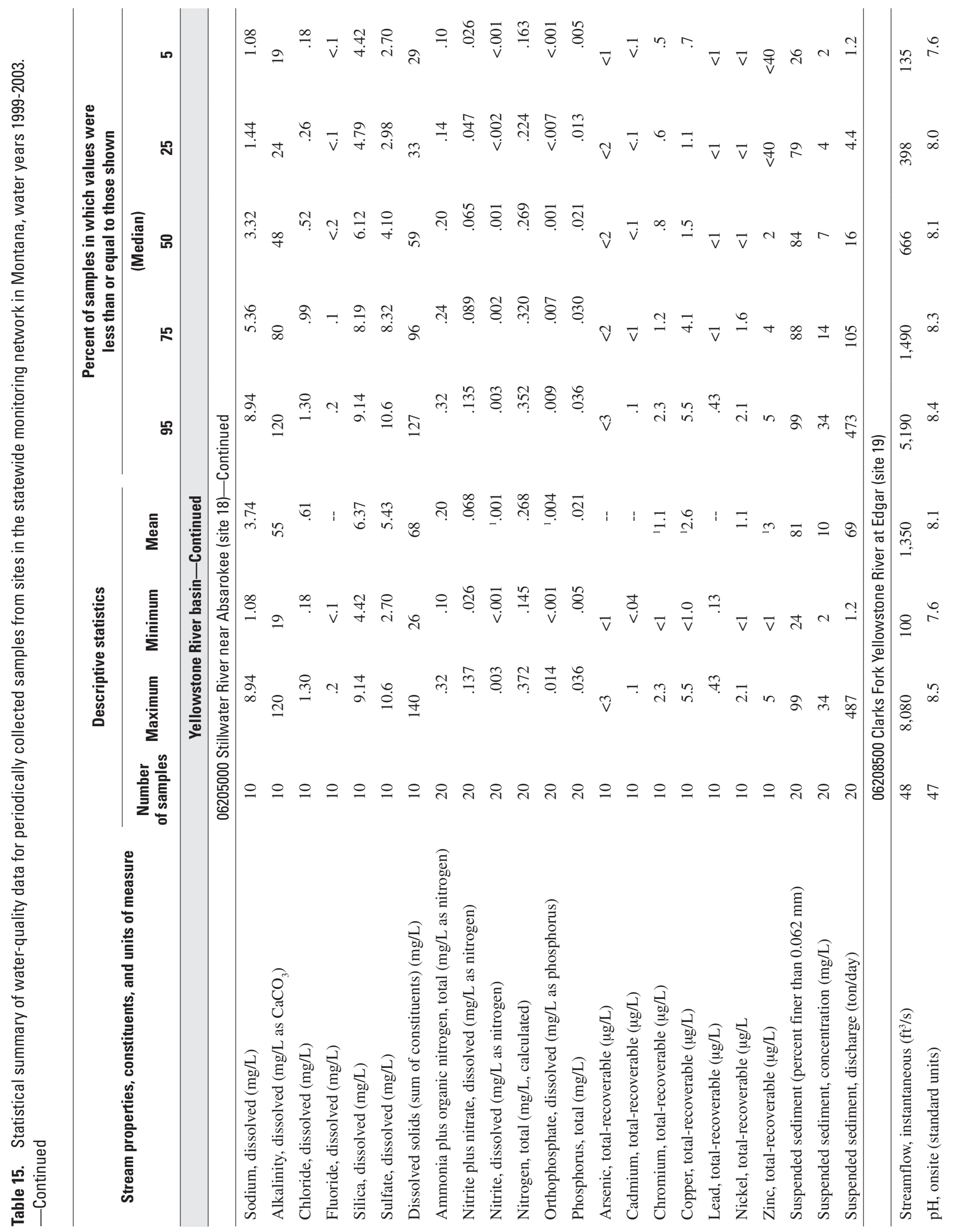




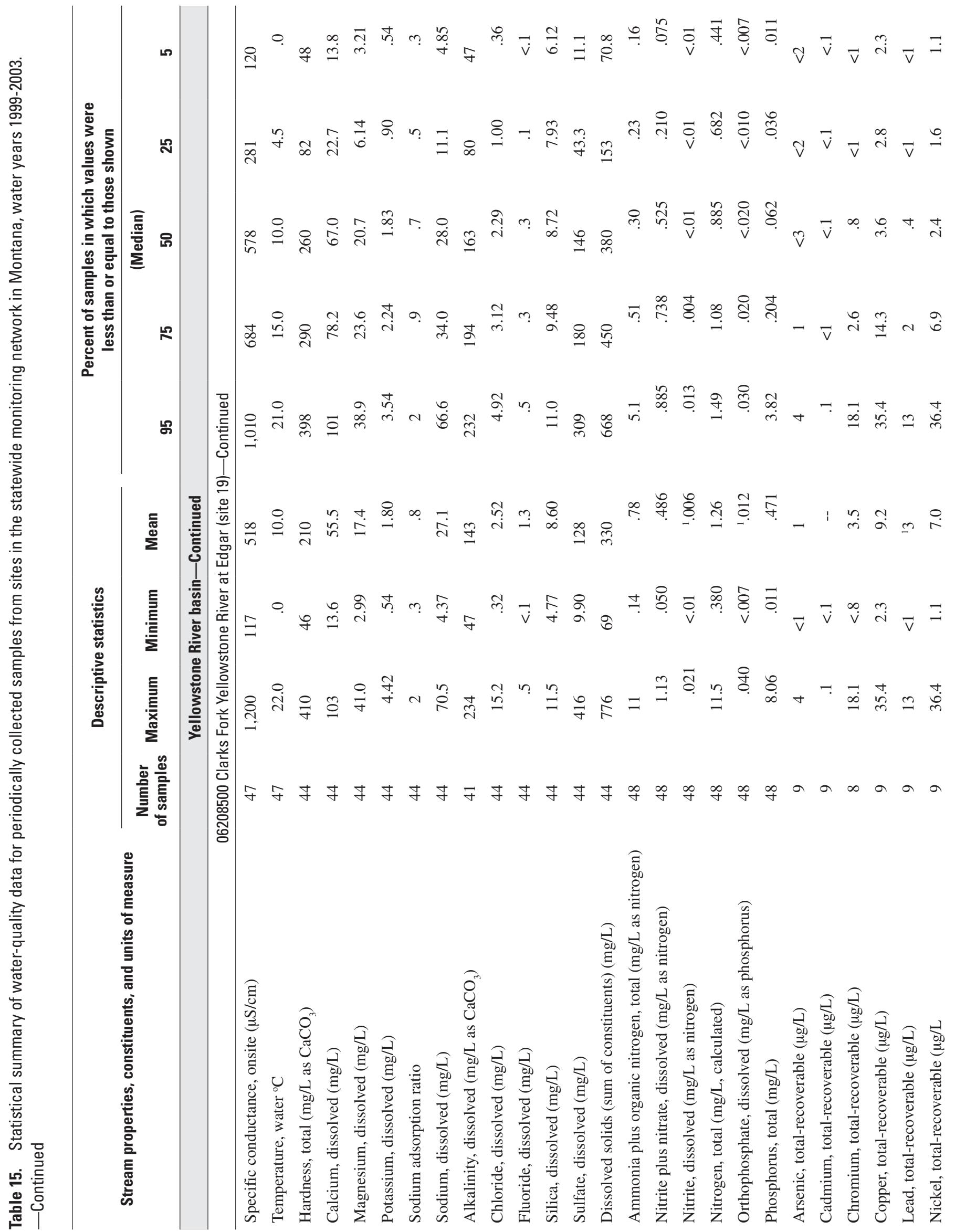




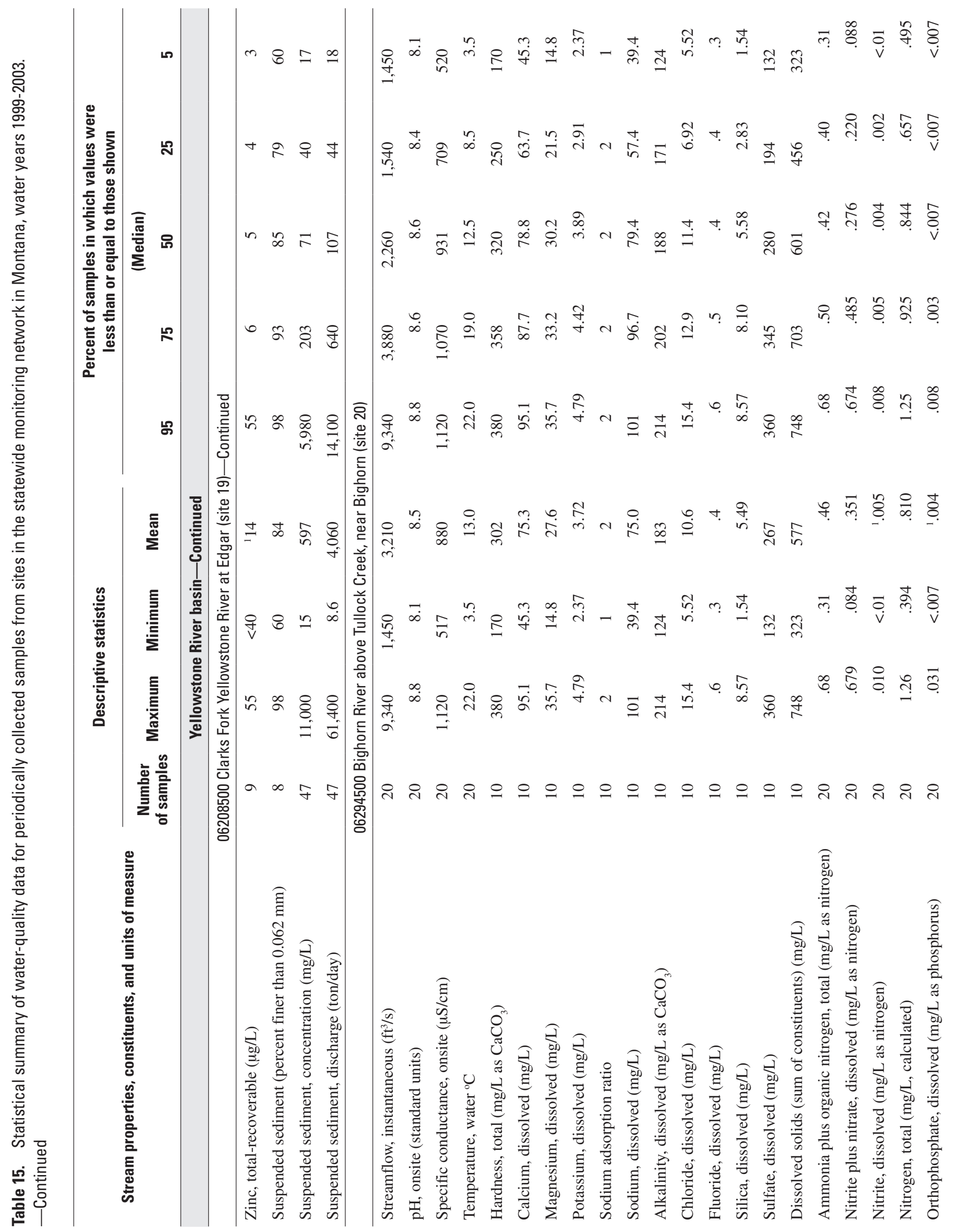




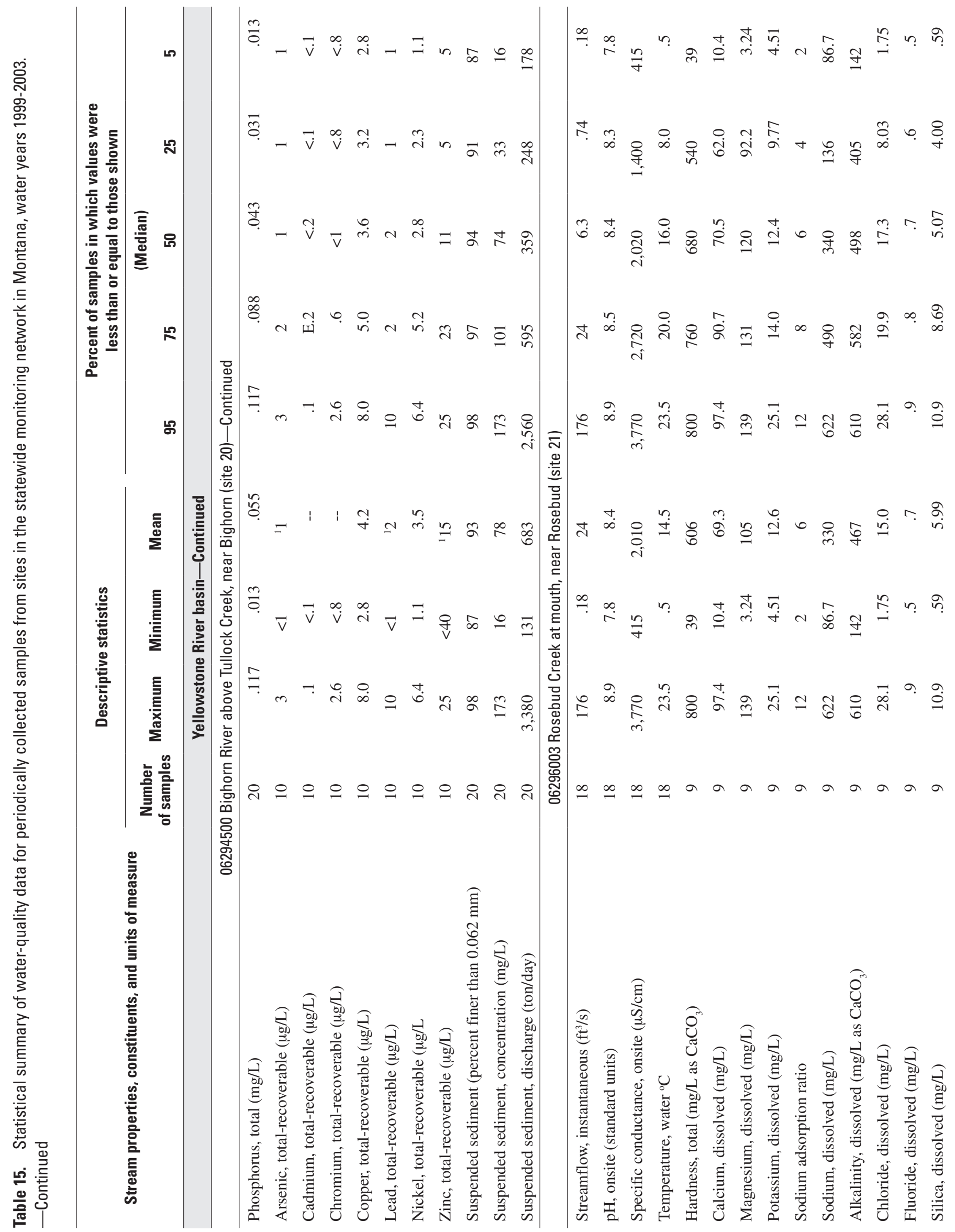




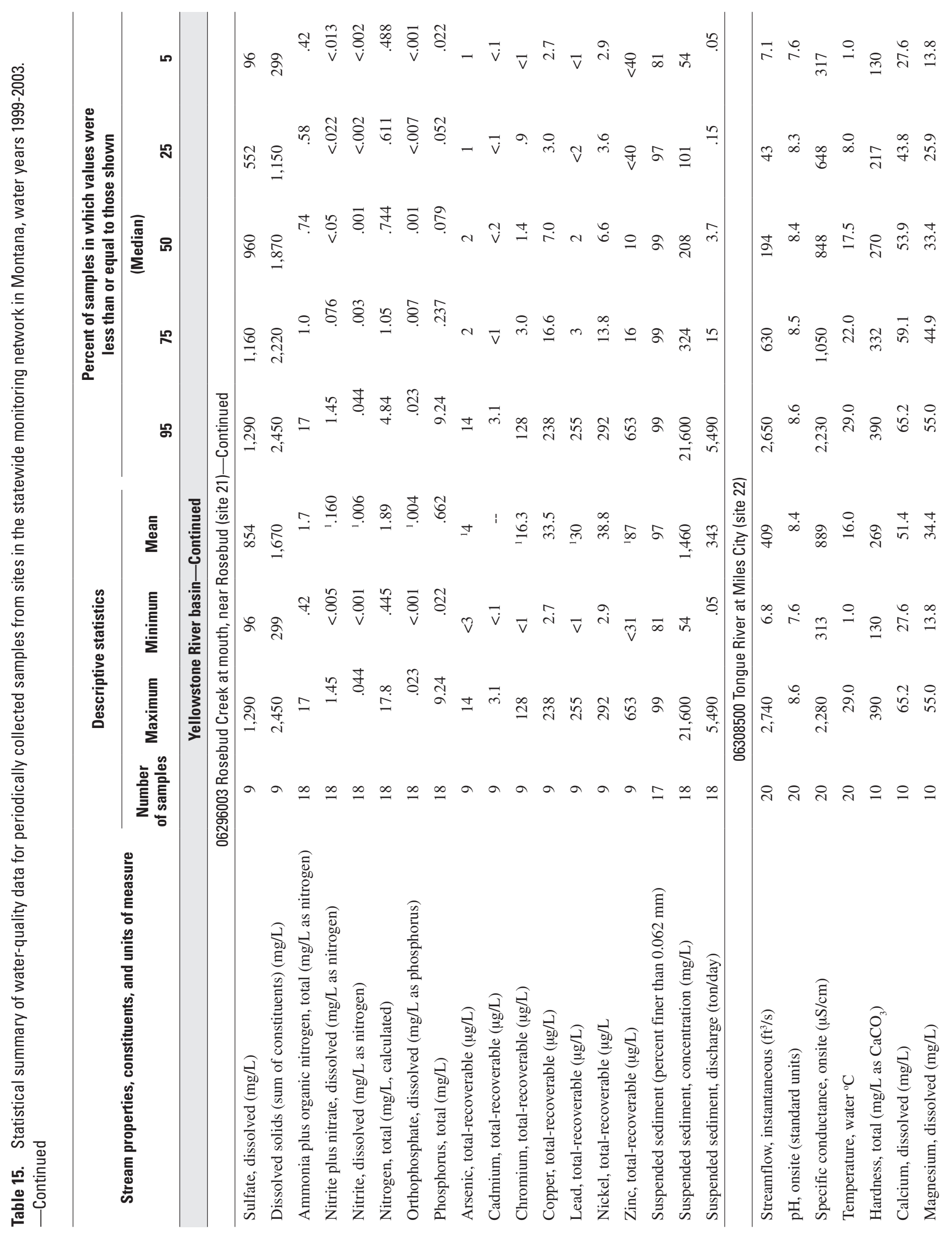




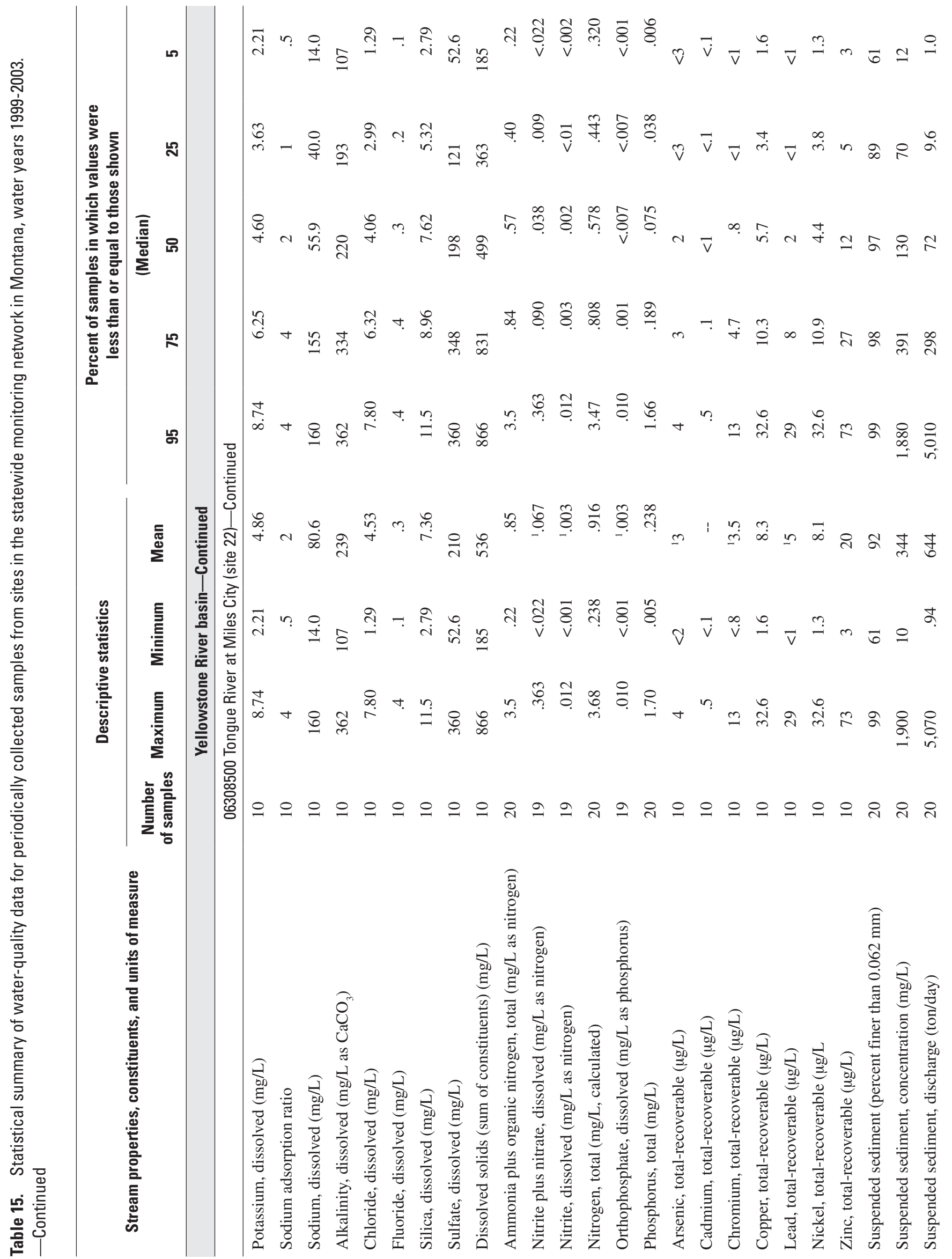




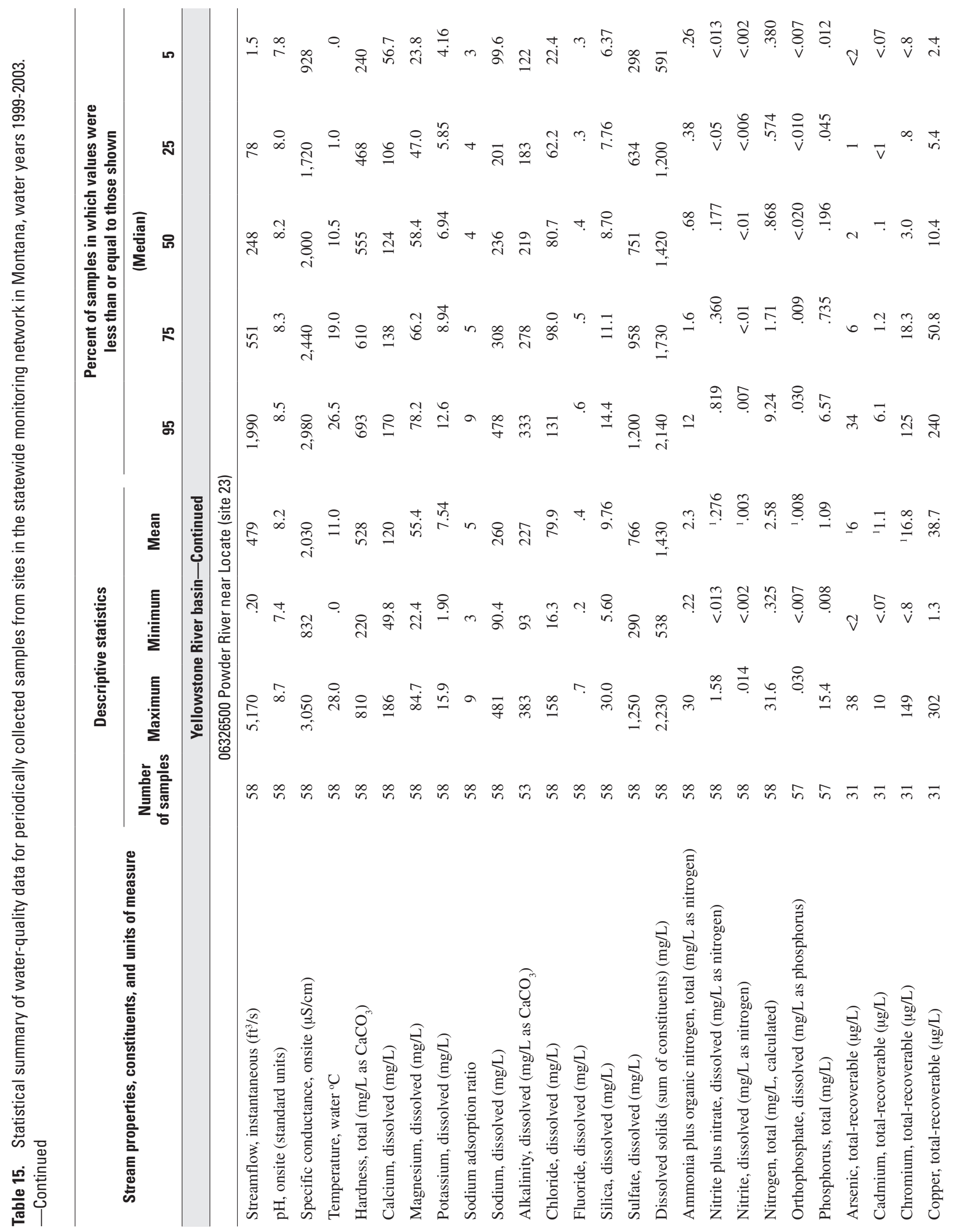




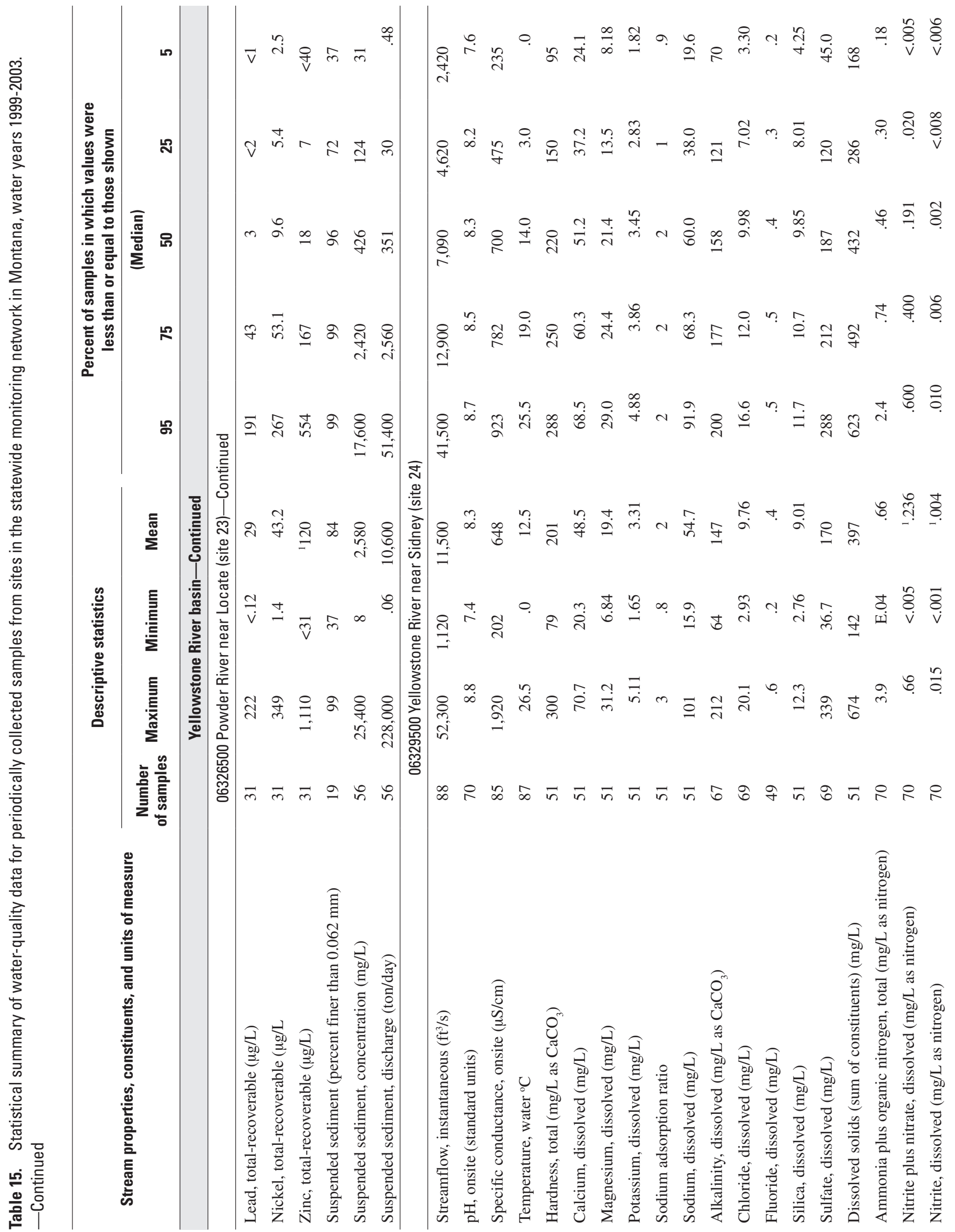




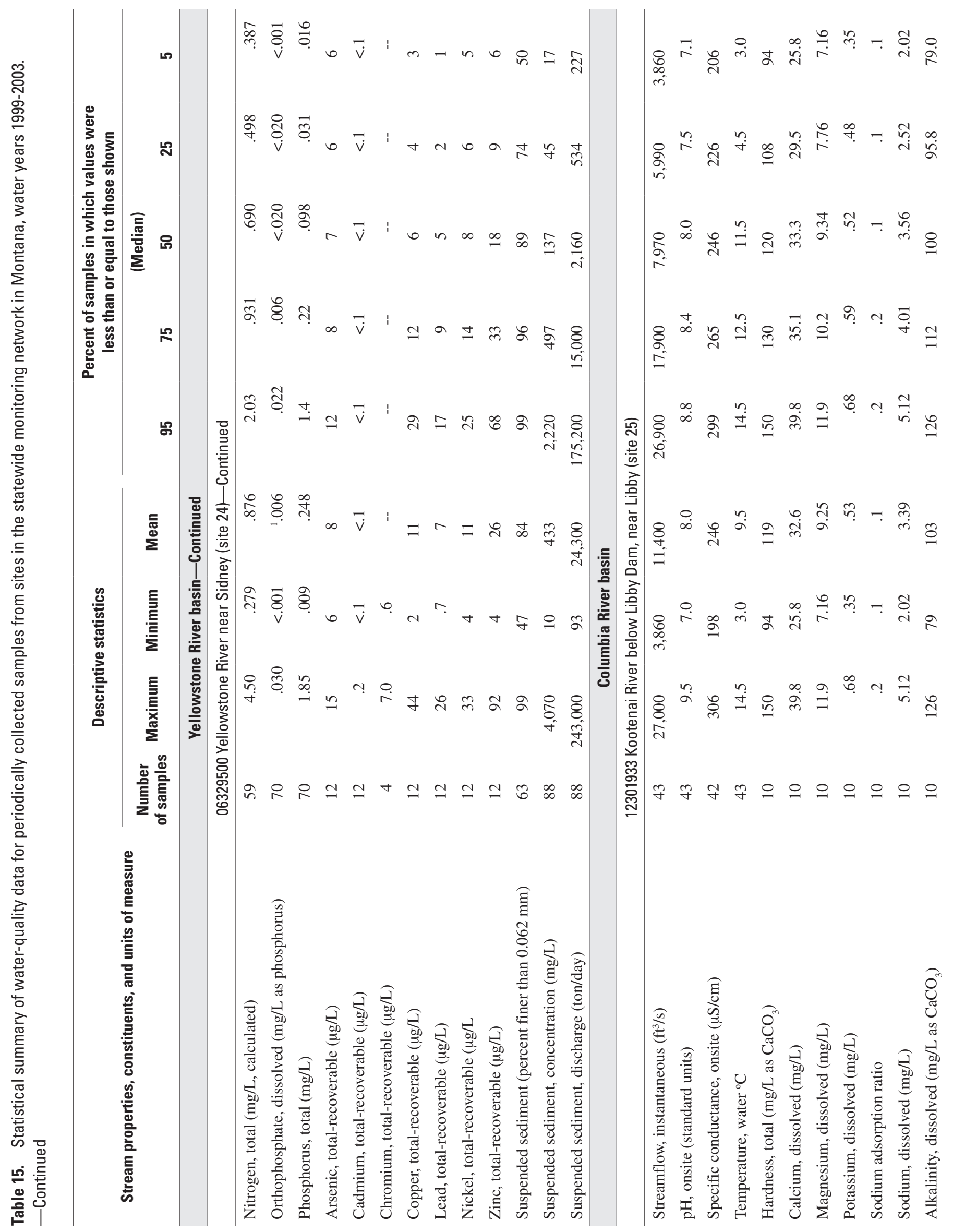




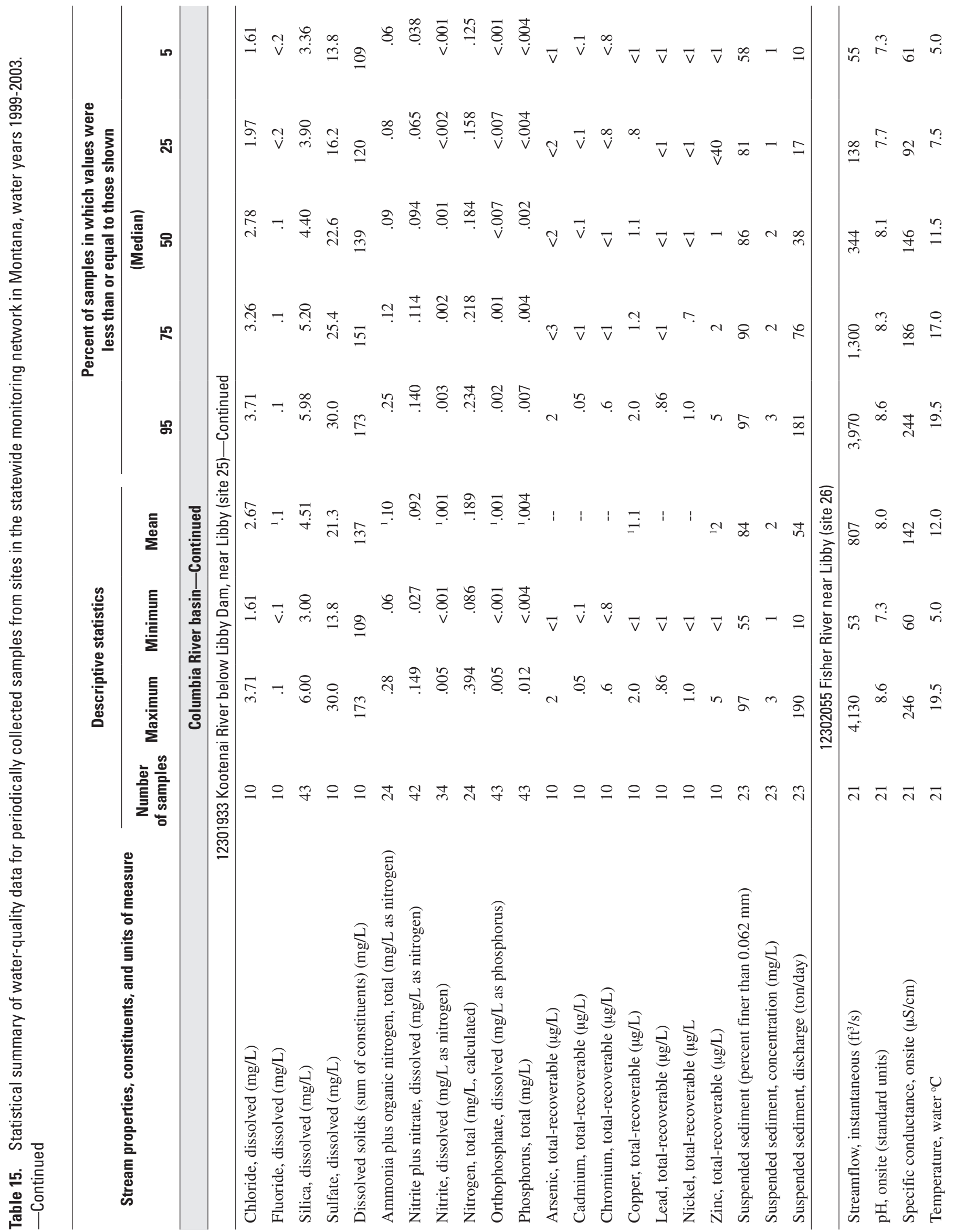




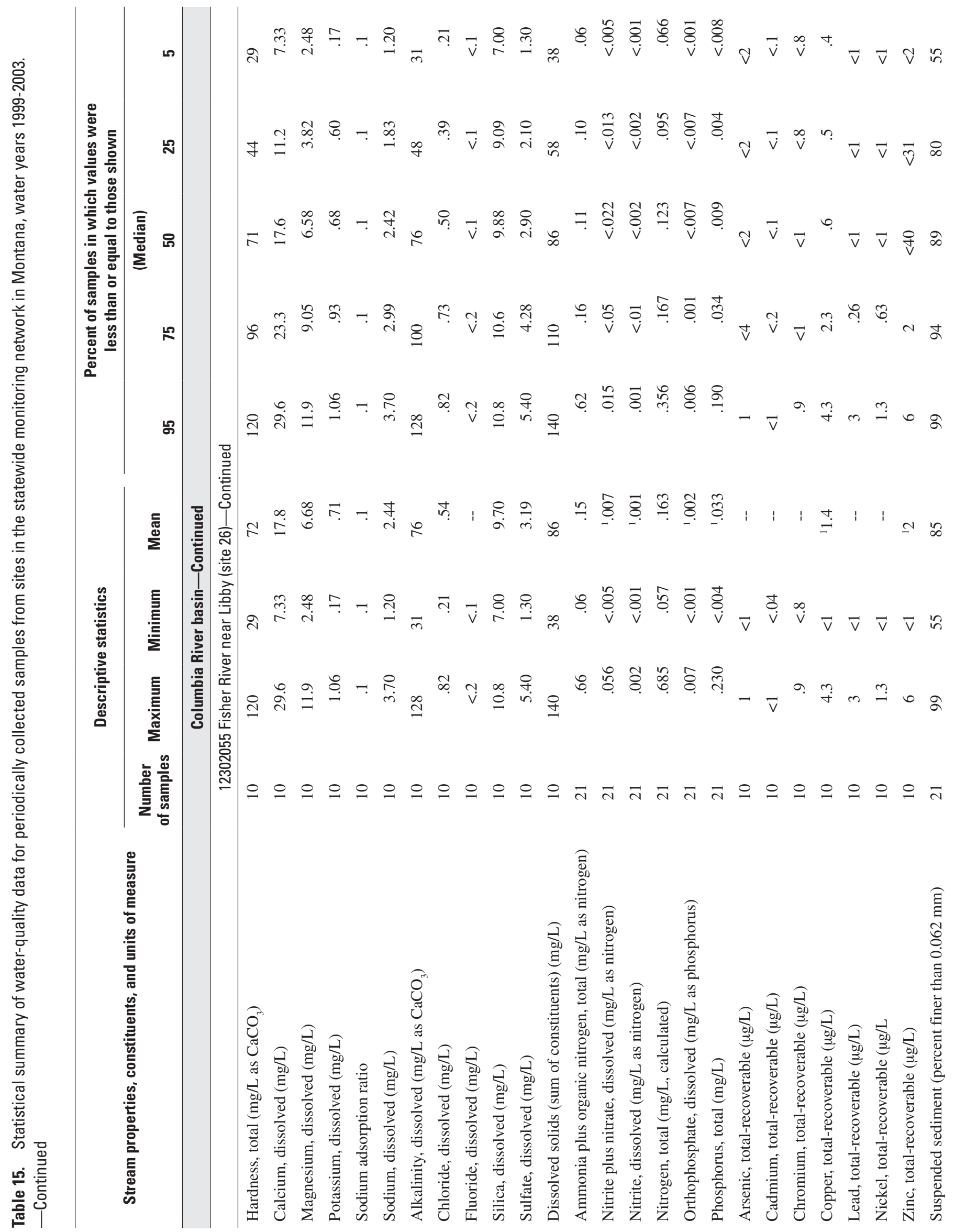




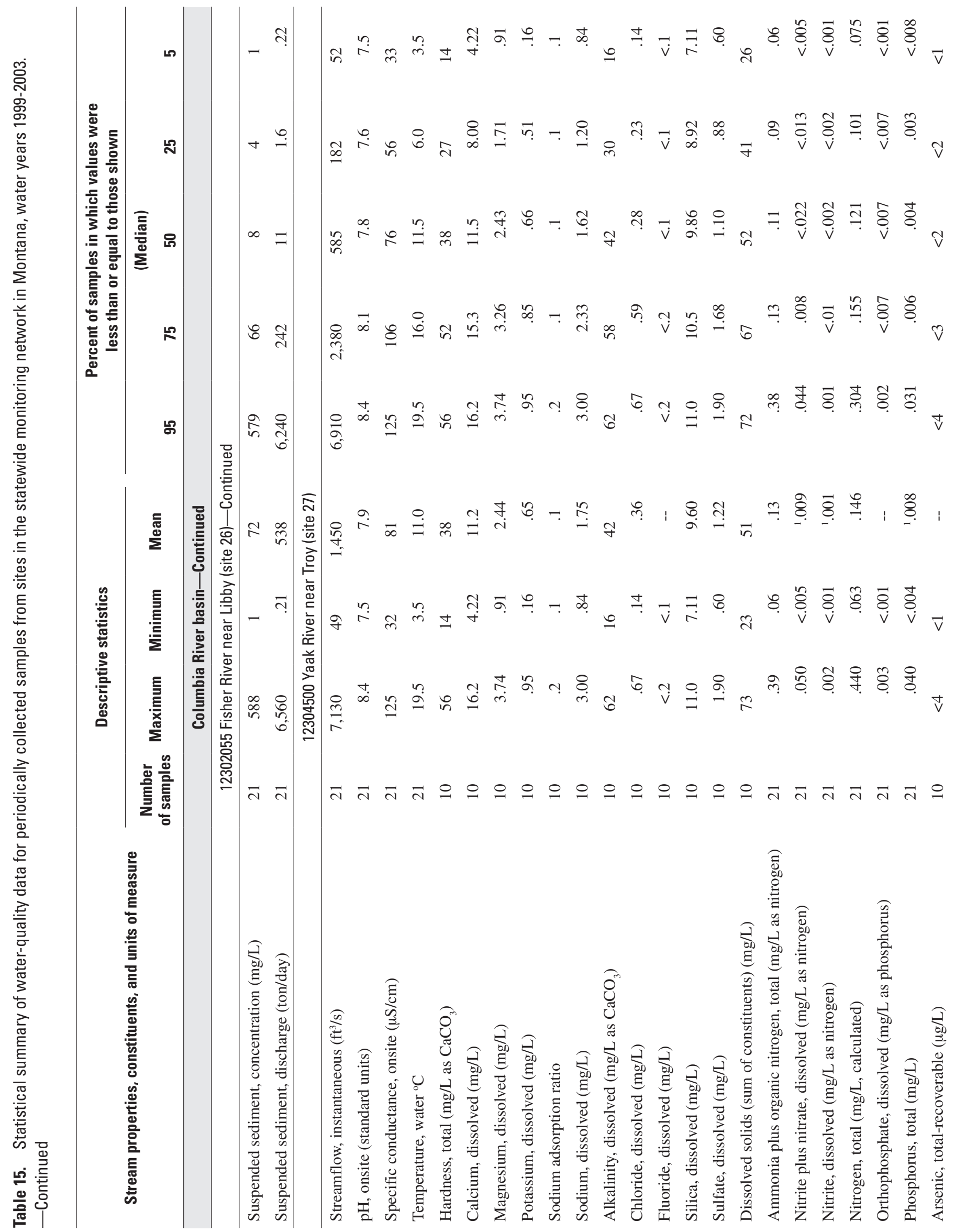




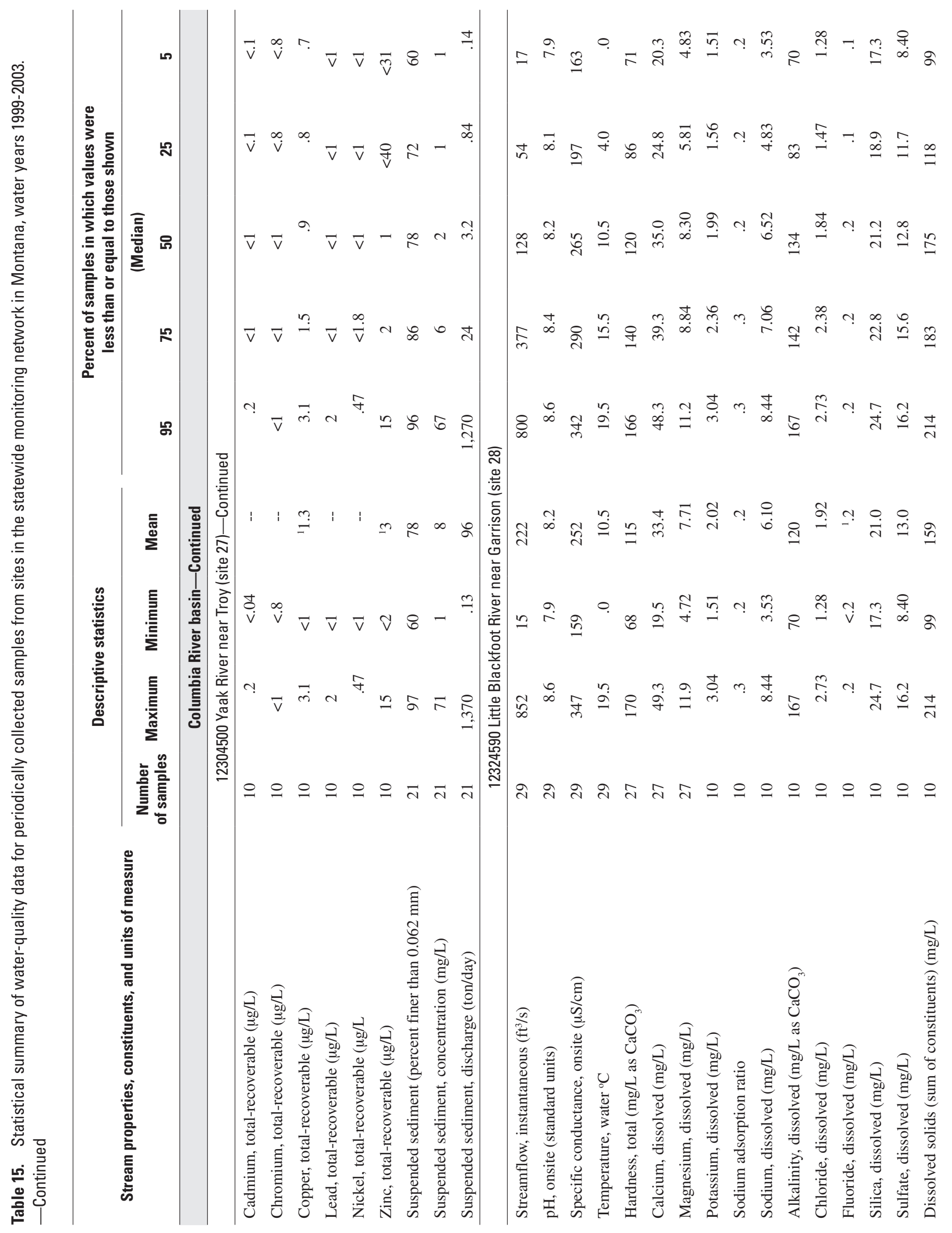




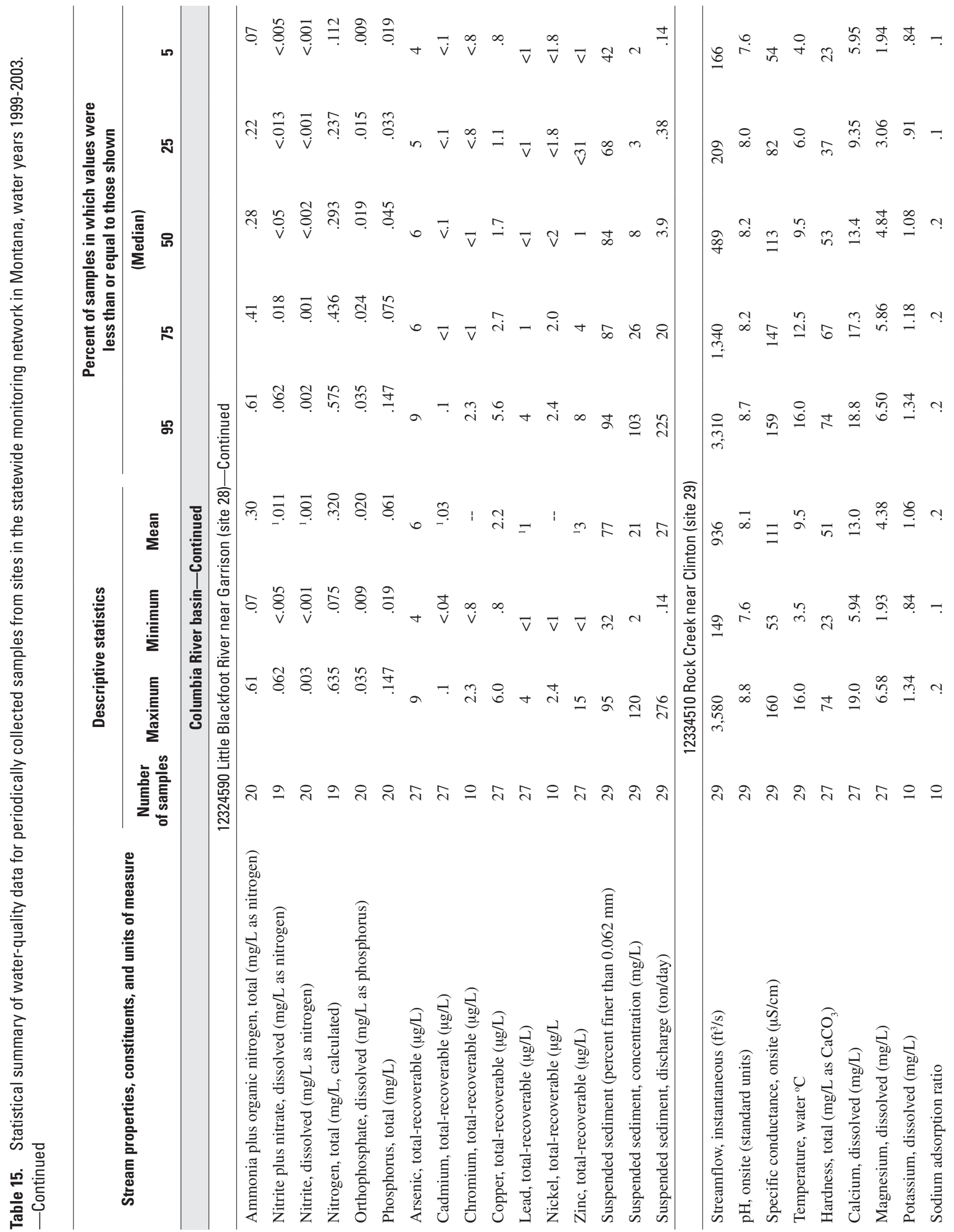


Data 137

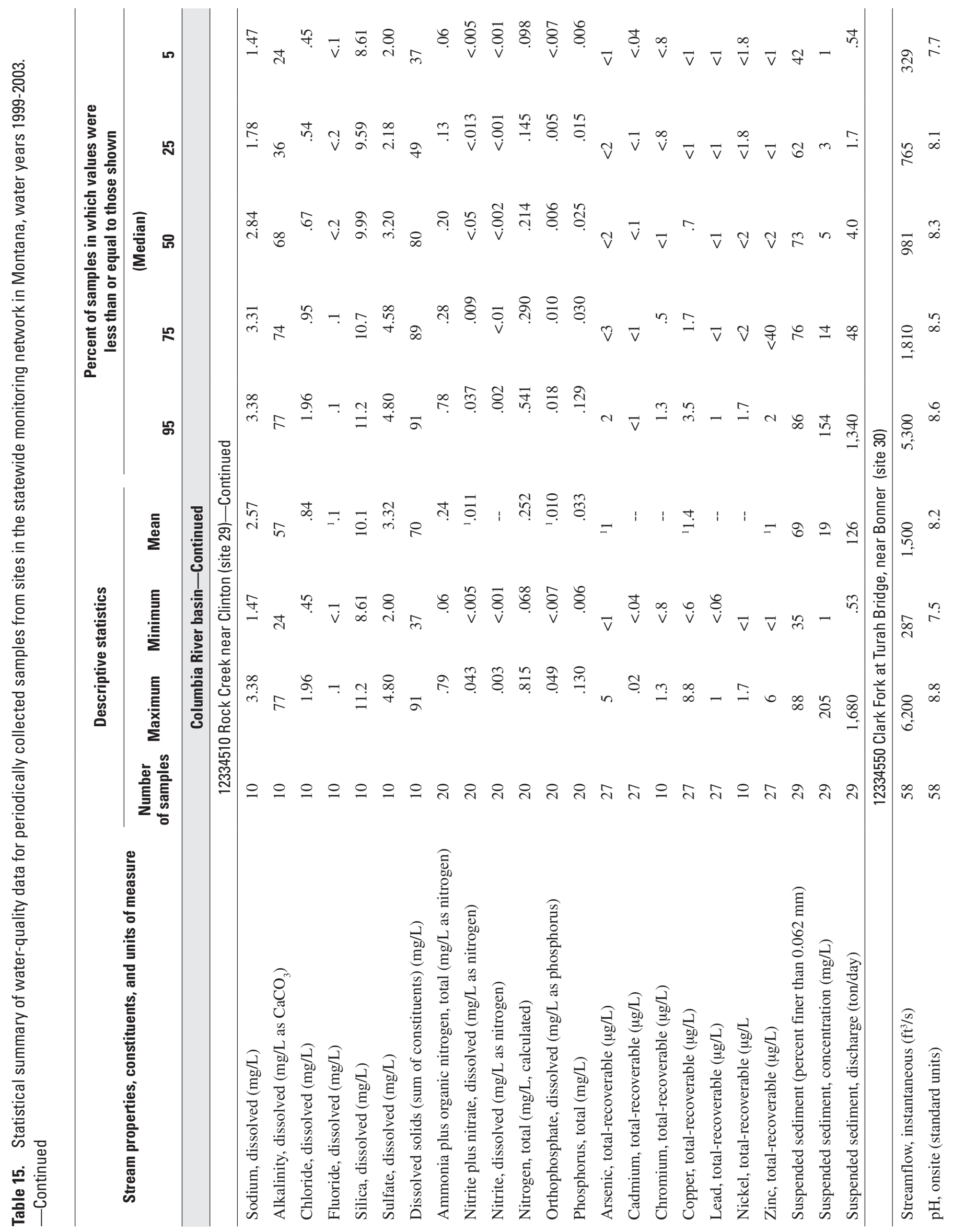




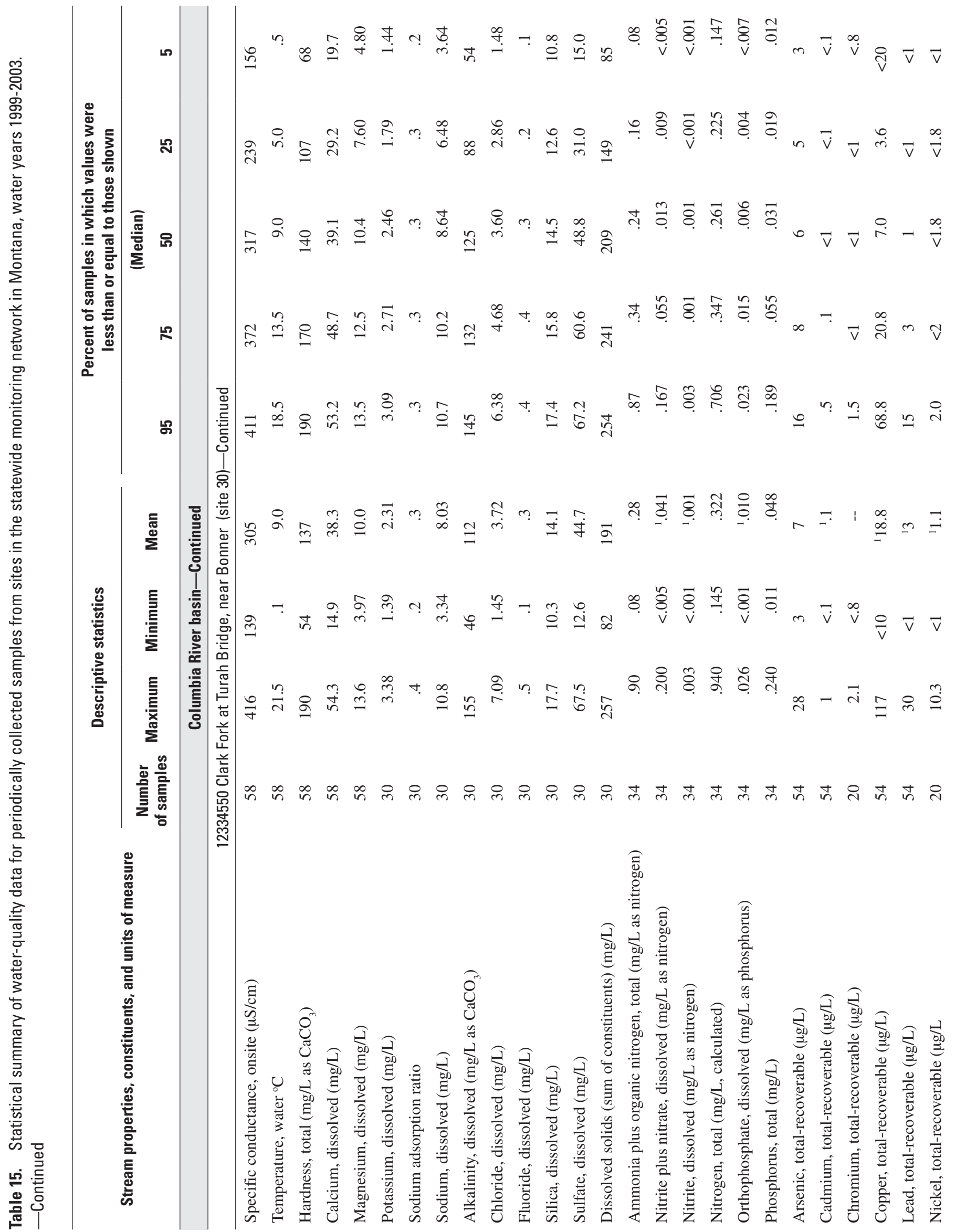




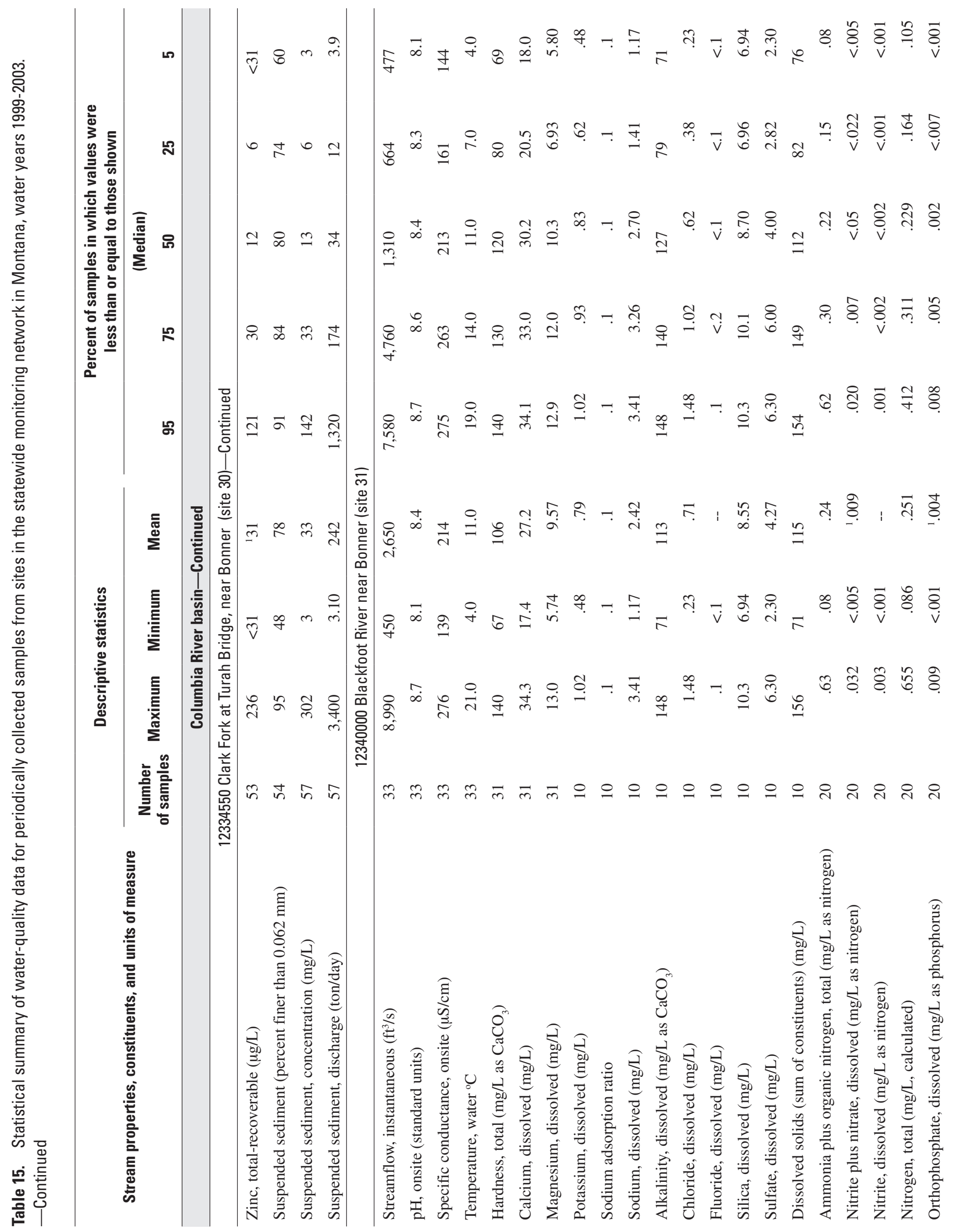




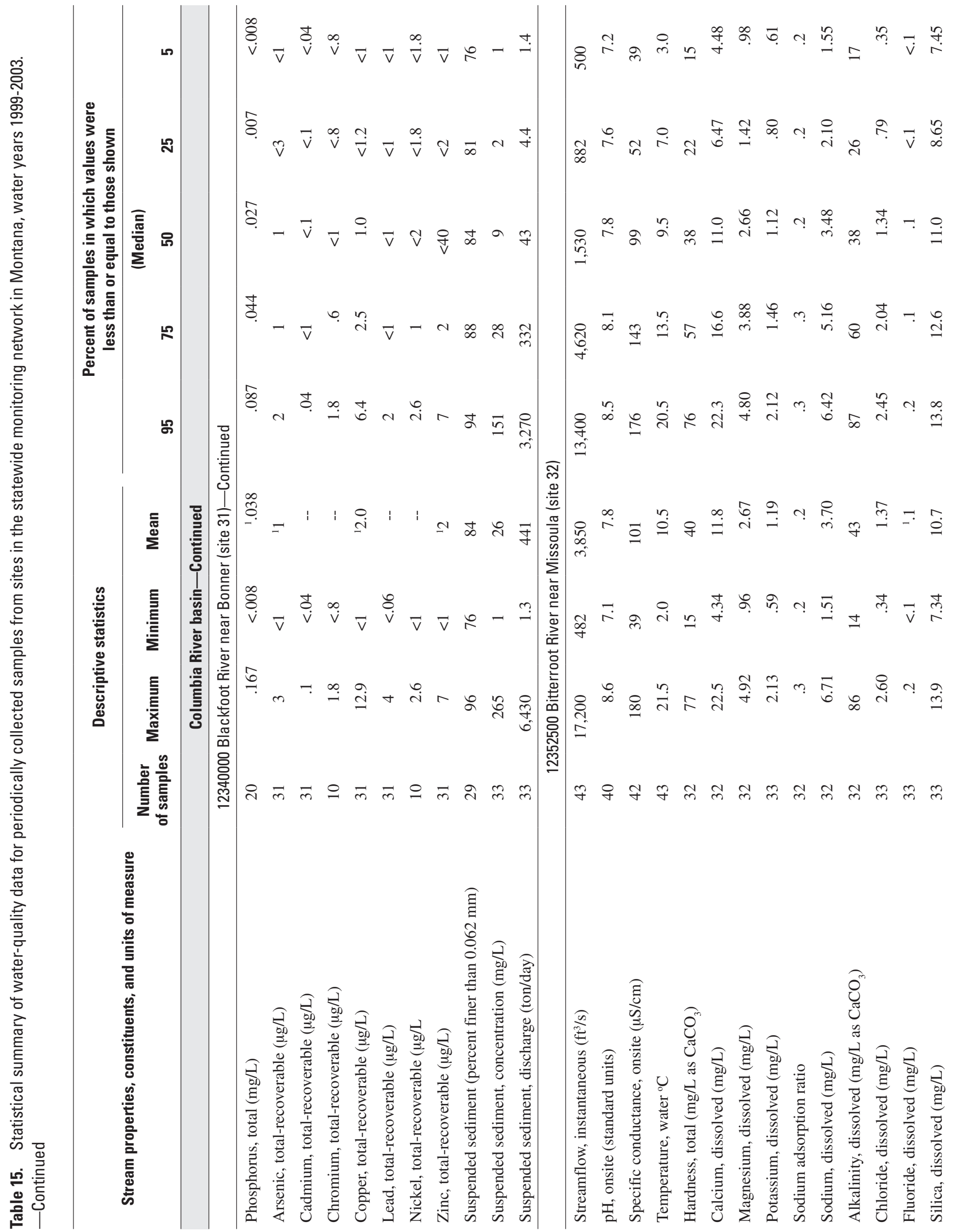




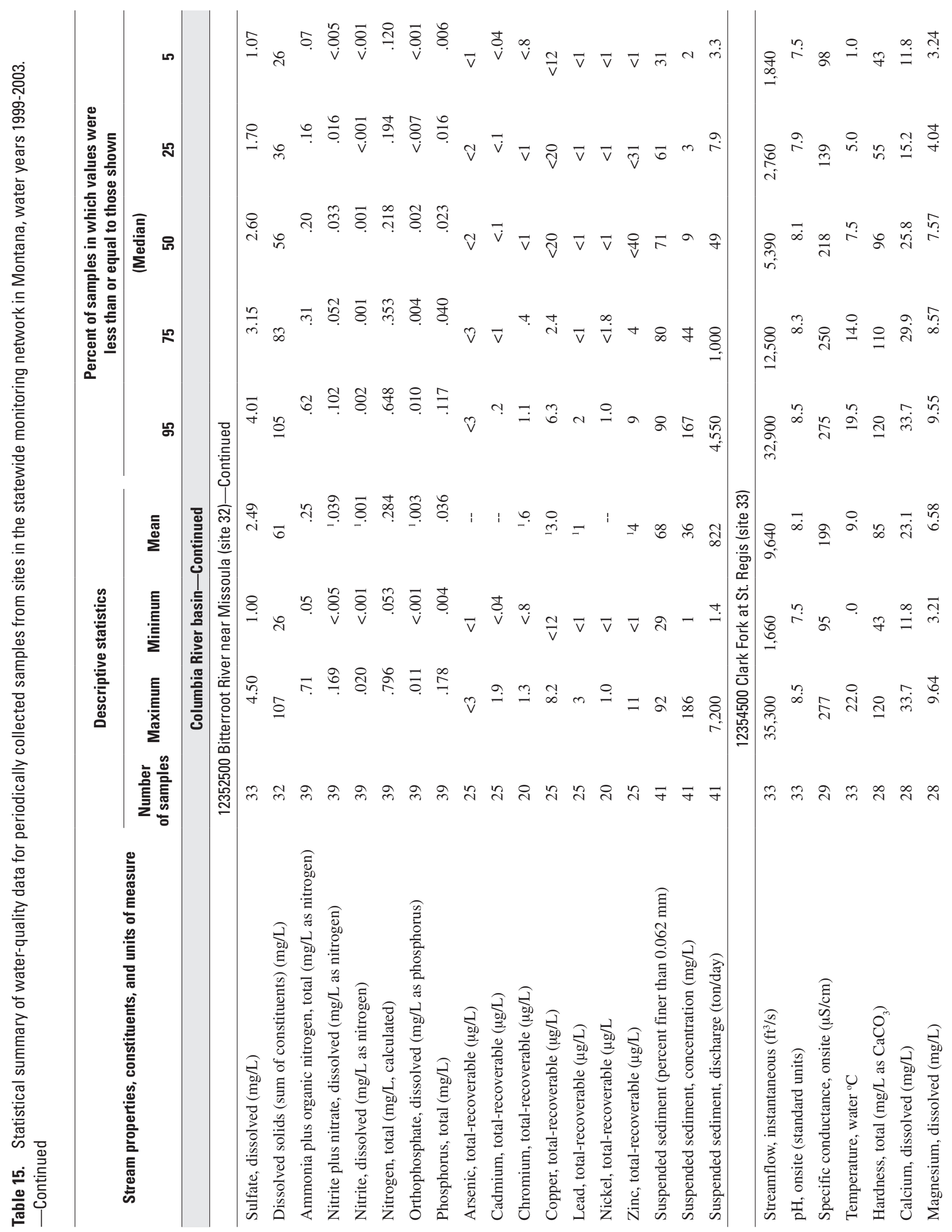




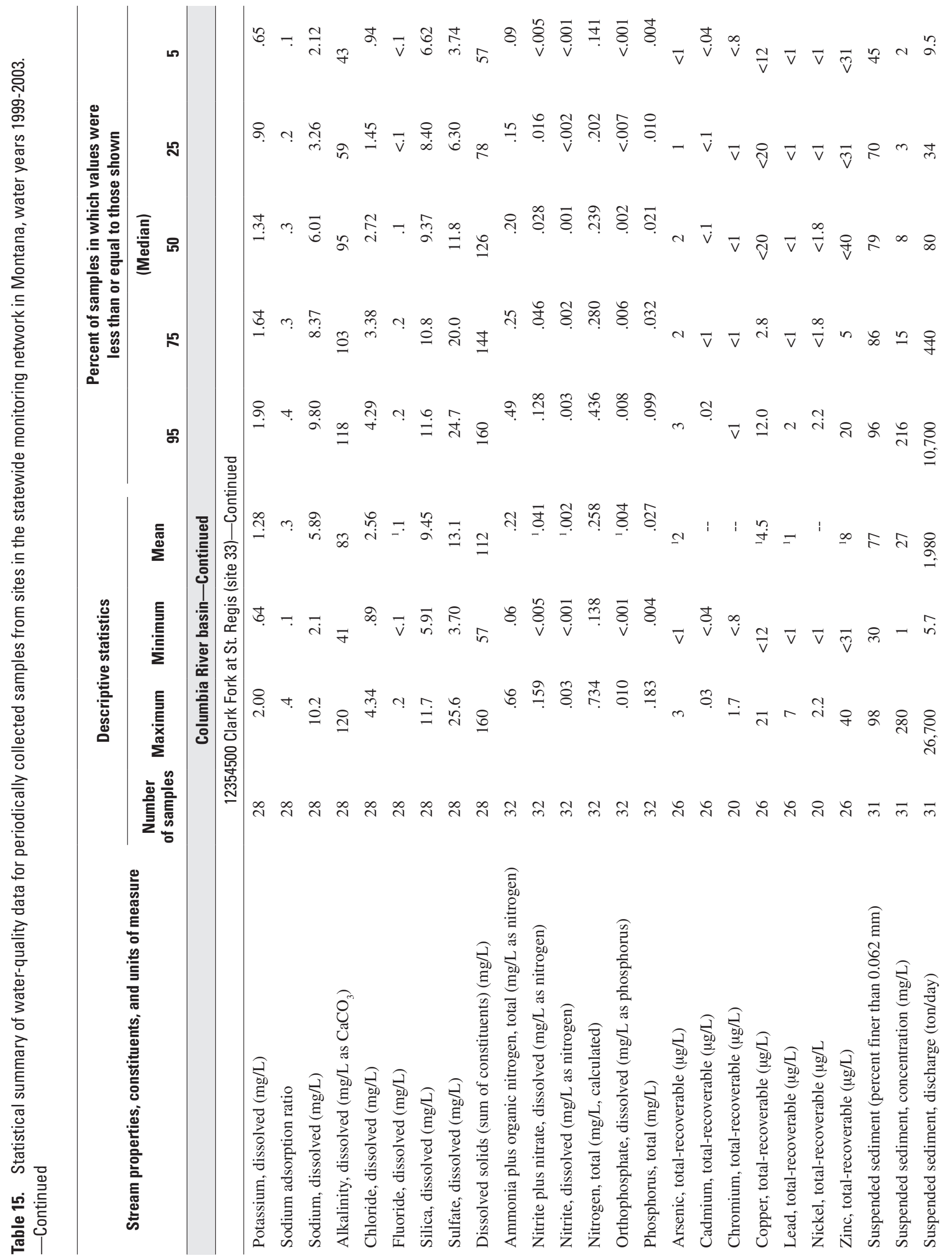




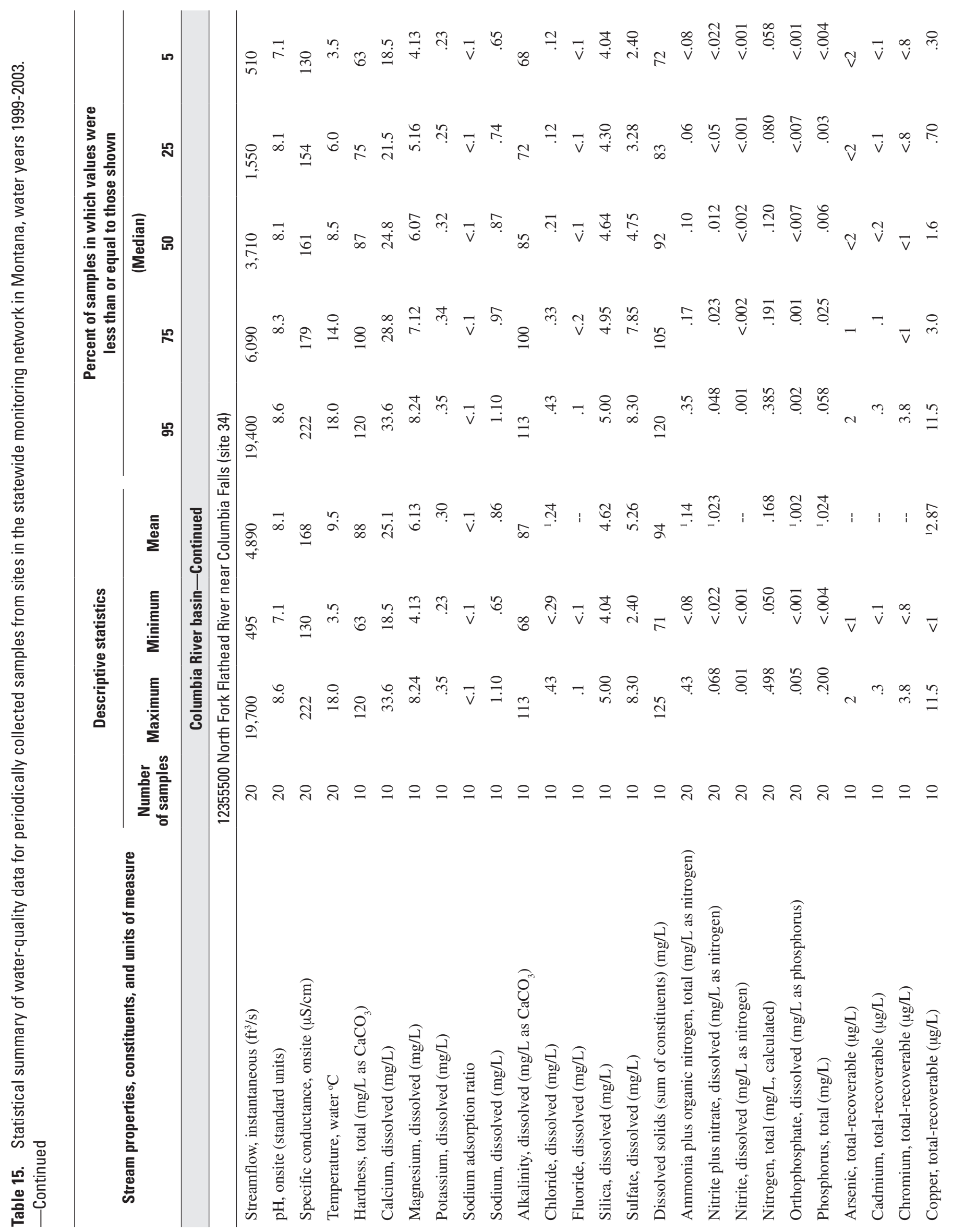




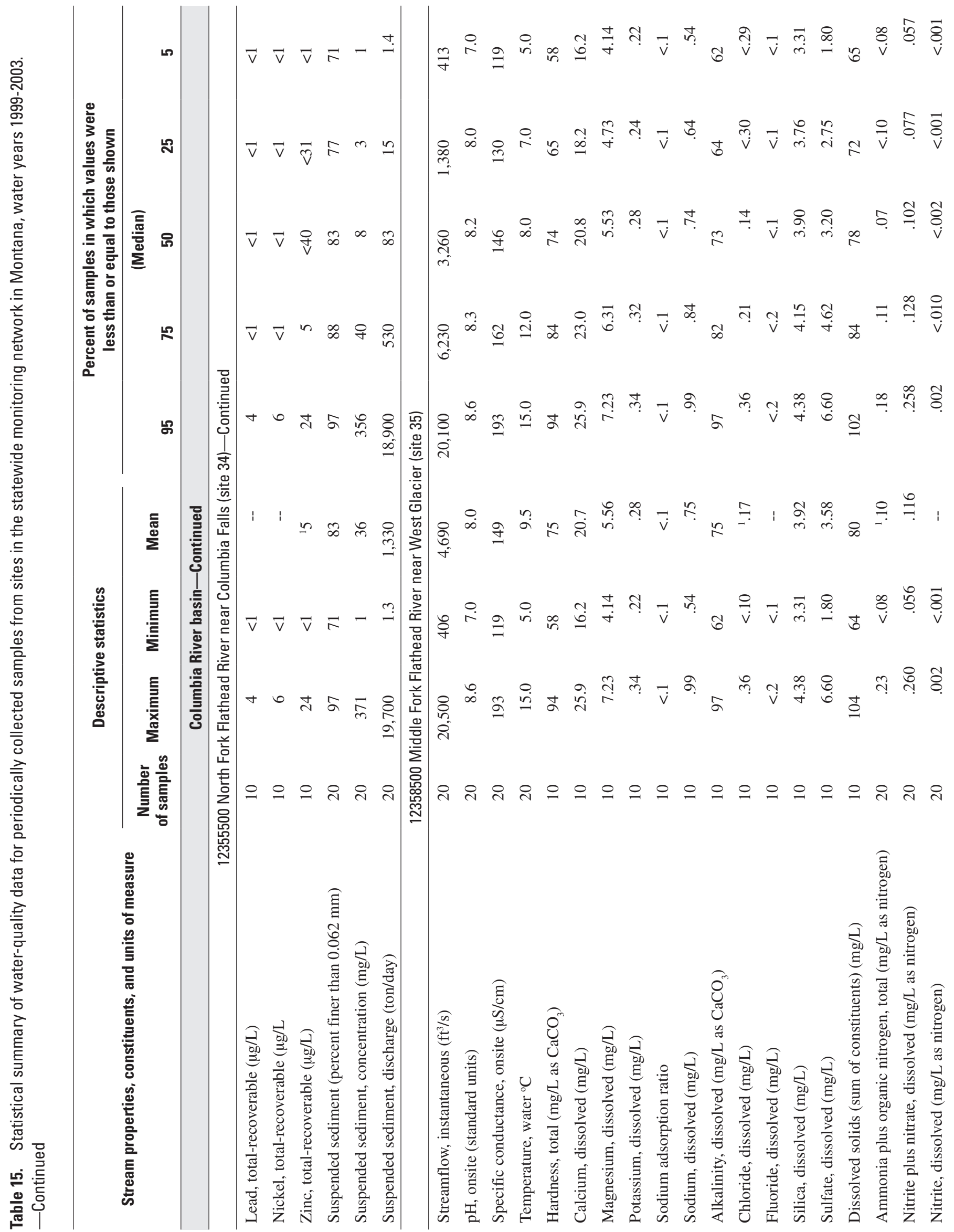




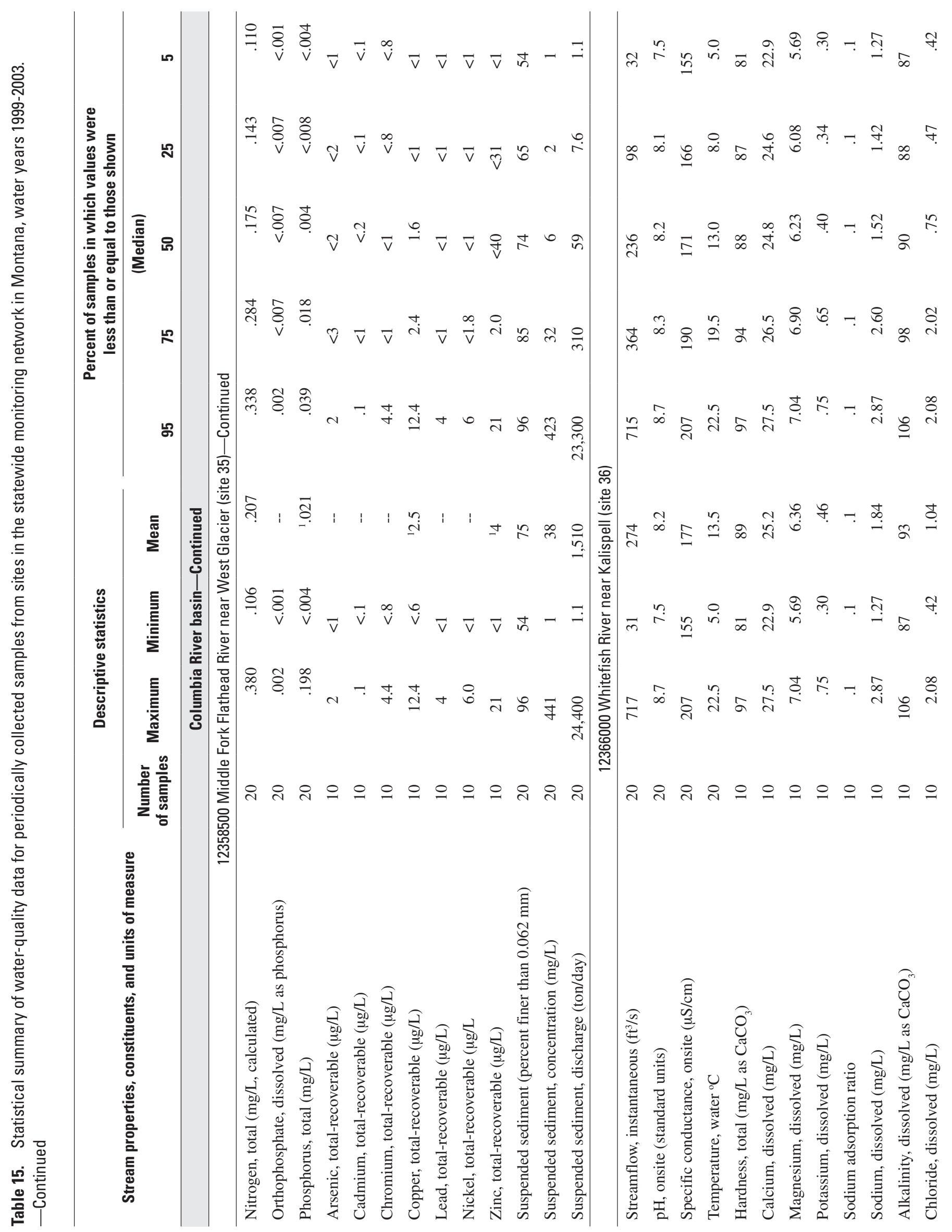




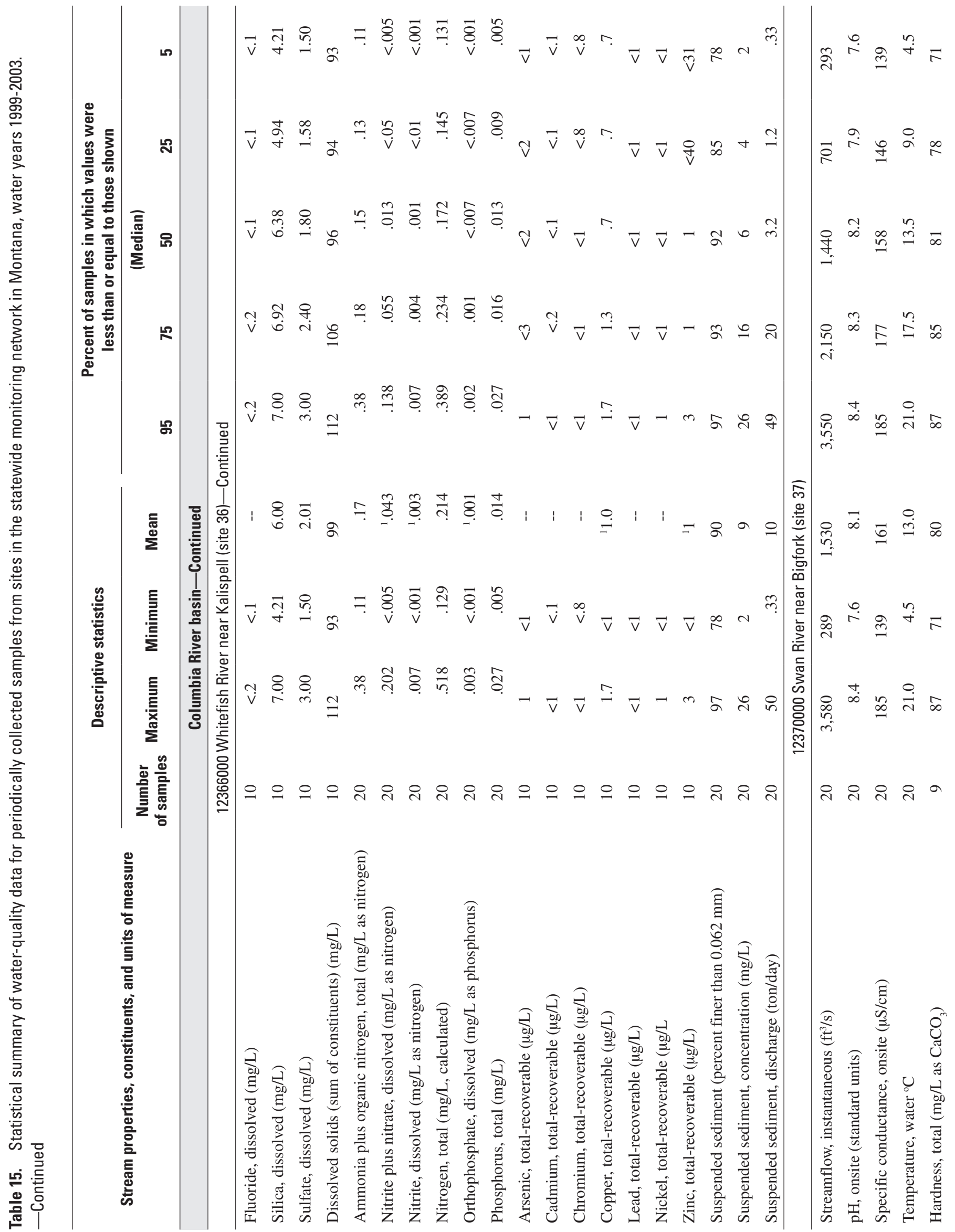




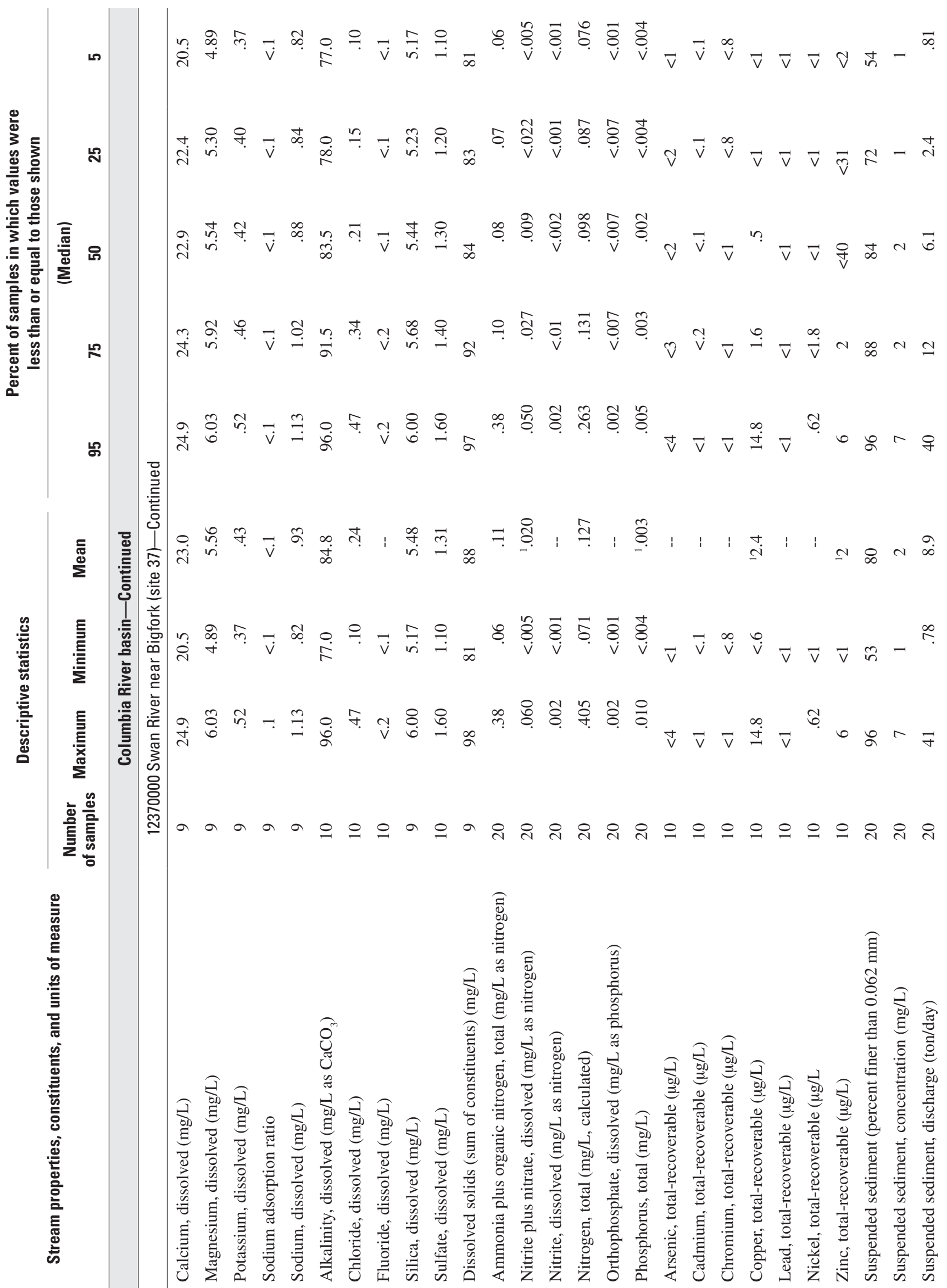




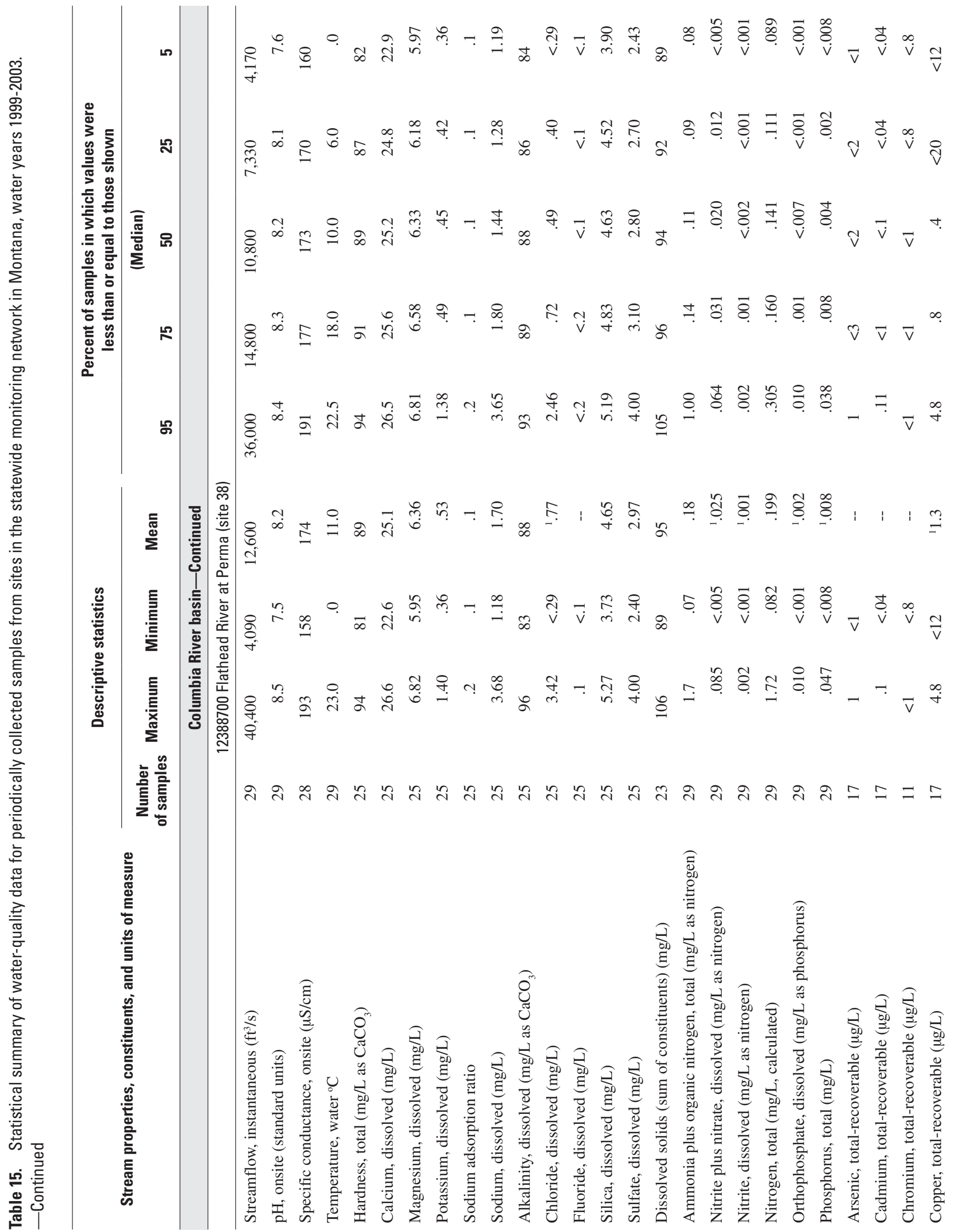




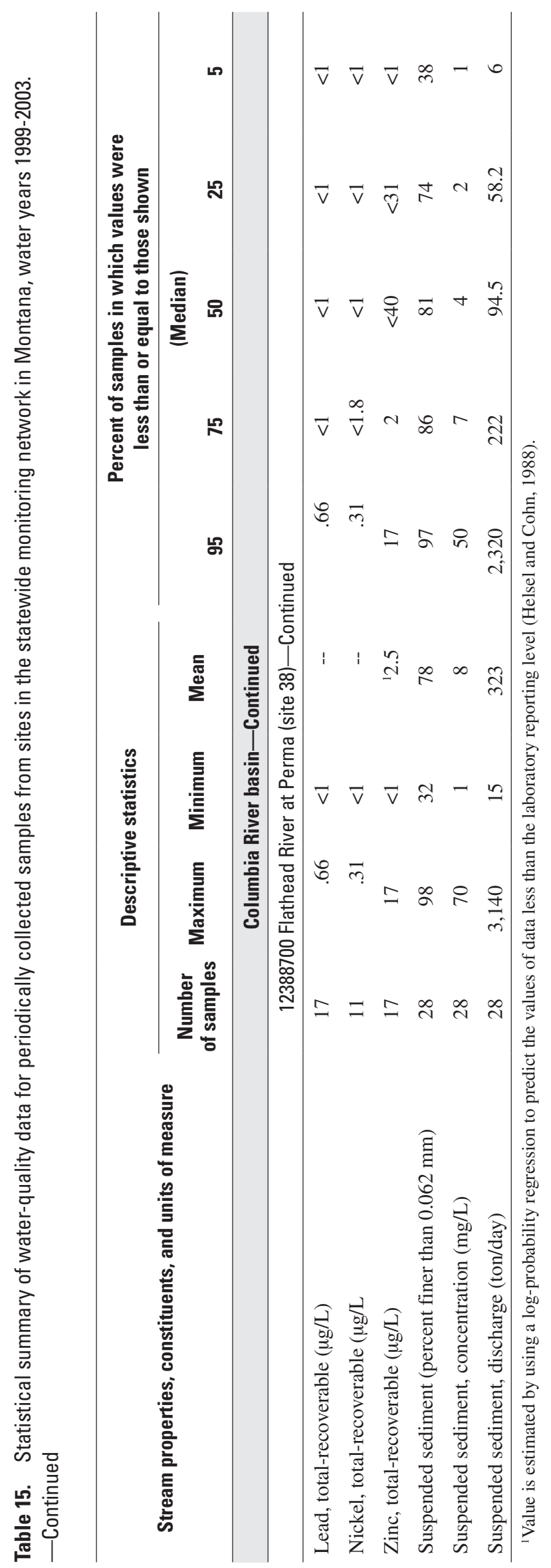


For additional information contact:

Director, Montana Water Science Center

U.S. Geological Survey

3162 Bozeman Avenue

Helena, Montana 59601

Telephone: 1-406-457-5900

World Wide Web: http://mt.water.usgs.gov/ 